ESCOLA POLITÉCNICA DA UNIVERSIDADE DE SÃO PAULO DEPARTAMENTO DE ENGENHARIA DE CONSTRUÇÃO CIVIL

JOSÉ CARLOS PALIARI

MÉTODO PARA PROGNÓSTICO DA PRODUTIVIDADE DA MÃO-DEOBRA E CONSUMO UNITÁRIO DE MATERIAIS: SISTEMAS PREDIAIS HIDRÁULICOS

v. 1 
JOSÉ CARLOS PALIARI

\section{MÉTODO PARA PROGNÓSTICO DA PRODUTIVIDADE DA MÃO-DE- OBRA E CONSUMO UNITÁRIO DE MATERIAIS: SISTEMAS PREDIAIS HIDRÁULICOS}

Tese apresentada à Escola Politécnica da Universidade de São Paulo para a obtenção do título de Doutor em Engenharia

v. 1

\section{SÃO PAULO}




\section{MÉTODO PARA PROGNÓSTICO DA PRODUTIVIDADE DA MÃO-DE- OBRA E CONSUMO UNITÁRIO DE MATERIAIS: SISTEMAS PREDIAIS HIDRÁULICOS}

Tese apresentada à Escola Politécnica da Universidade de São Paulo para a obtenção do título de Doutor em Engenharia

Área de Concentração:

Engenharia de Construção Civil e Urbana

Orientador: Prof. Livre-Docente Ubiraci Espinelli Lemes de Souza

v. 1

\section{SÃO PAULO}


Este exemplar foi revisado e alterado em relação à versão original, sob responsabilidade única do autor e com a anuência de seu orientador.

São Paulo, 18 de janeiro de 2008.

Assinatura do autor

Assinatura do orientador

\section{FICHA CATALOGRÁFICA}

Paliari, José Carlos

Método para prognóstico da produtividade da mão-de-obra e consumo unitário de materiais : sistemas prediais hidráulicos I J.C. Paliari. -- ed.rev. -- São Paulo, 2008.

$2 \mathrm{v}$.

Tese (Doutorado) - Escola Politécnica da Universidade de São Paulo. Departamento de Engenharia de Construção Civil.

1. Consumo unitário de materiais 2. Produtividade da mão-de-obra 3. Orçamento I. Universidade de São Paulo. Escola Politécnica. Departamento de Engenharia de Construção Civil II. $\mathbf{t}$ 
Aos meus pais, Nelson e Iraci, e meus irmãos, Luciano, Paulo e Sandra, por terem sido a base fundamental de toda a minha formação pessoal e por proporcionarem a viabilização desta etapa profissional da minha vida.

A minha esposa Jussara, pelo incentivo nos momentos mais difíceis deste trabalho e pela compreensão da minha ausência em muitos momentos durante o desenvolvimento desta tese. 


\section{Agradecimentos}

É com muita satisfação que, ao término de mais este trabalho, venho aqui expressar meus sinceros agradecimentos a inúmeros amigos que, de uma forma ou de outra, contribuíram significativamente para sua conclusão.

Inicialmente, gostaria de agradecer ao Prof. Dr. Ubiraci Espinelli Lemes de Souza pela amizade, parceria em diversos trabalhos realizados durante este meu amadurecimento como pesquisador e, principalmente, pela orientação nos momentos mais cruciais desta tese.

Ao Prof. Dr. Almir Sales, colega de trabalho do Departamento de Engenharia Civil da UFSCar, pelo apoio e incentivo constante durante o desenvolvimento e etapa de finalização deste trabalho e por ter assumido a turma de Tecnologia de Construção de Edificações, sob minha responsabilidade, durante o período em que precisei me afastar para desenvolver este doutoramento.

Ao Prof. Dr. Simar Viera de Amorim, docente do Departamento de Engenharia Civil da UFSCar, por muitas vezes ter sanado minhas dúvidas com relação aos Sistemas Prediais Hidráulicos.

Ao Prof. Dr. Celso Carlos Novaes e MSc. Itamar Aparecido Lorenzon por terem conduzidos a disciplina Projeto Integrado de Sistemas Construtivos, também de minha responsabilidade, durante a minha ausência da UFSCar.

Às empresas construtoras Tecnum, Zabo Engenharia, Cosil, Tarjab, Sinco, Adolpho Lindenberg, na figura de seus gerentes de obras e diretores, por terem cedidos os projetos de sistemas prediais para a realização deste trabalho e, em particular, à Cyrela, Filippo, Barbara e EBM por terem também disponibilizados seus canteiros de obras para a análise da produtividade da mão-de-obra.

Aos professores Francisco Ferreira Cardoso e Orestes Marracini Gonçalves pelas valiosas contribuições durante o meu Exame de Qualificação. 
Ao meu colega de graduação Maurício Milhin pela acolhida em São Paulo junto a sua família. Foram momentos agradáveis, principalmente aos relacionados às lembranças da graduação em São Carlos. Reviver esta história contribuiu para amenizar a saudade da minha família.

Aos meus auxiliares de pesquisa da cidade de São Paulo, Douglas S. Araújo, e da cidade de São Carlos, Marco Polverni Reichert, Thiago Luís Rodrigues da Silva e Victor Greco, pelo auxílio na coleta de dados, processamento das informações e manipulação dos desenhos em Autocad.

Ao amigo Rogério pela resolução de um problema sério em meu computador no momento que imaginava que tudo estava perdido.

A Fátima Regina G.S. Domingues, secretária do PCC, pela presteza no fornecimento de informações e auxílio nos procedimentos administrativos relacionados ao desenvolvimento do doutoramento.

Aos meus colegas de Pós-Graduação, em particular a Artemária, pela amizade e excelente convívio durante os momentos de pesquisa e estudos nos vários trabalhos realizados ao longo da Pós-Graduação.

Ao CNPq pelo suporte financeiro para a realização desta pesquisa.

A DEUS pela família, esposa e amigos que tenho. 


\section{Resumo}

Este trabalho tem como objetivo a elaboração de um método para se prognosticar a produtividade da mão-de-obra na execução dos sistemas prediais hidráulicos e o consumo unitário de materiais destes sistemas em dois momentos distintos: fase de viabilidade do empreendimento (método simplificado) e na fase de anteprojeto ou projeto de arquitetura (método analítico). São apresentados os fundamentos que nortearam a elaboração do método proposto, envolvendo a conceituação sobre produtividade da mão-de-obra, consumo unitário de materiais e sistemas prediais. Além destes fundamentos teóricos, faz-se o detalhamento do método de coleta e processamento das informações para a obtenção destes indicadores, abordando o planejamento da coleta de dados, a coleta de dados propriamente dita e seu processamento. Os resultados sobre a produtividade da mão-de-obra são relativos a quatro canteiros de obras localizados no Estado de São Paulo, enquanto que os resultados sobre o consumo unitário de materiais são frutos da análise e levantamento de informações de 12 projetos de sistemas prediais hidráulicos de edifícios residenciais de múltiplos pavimentos. Como contribuição desta tese destaca-se a obtenção de indicadores de produtividade da mão-de-obra considerando as tarefas e subtarefas inerentes à execução dos sistemas prediais, com distintos níveis de esforço, diferentemente dos manuais de orçamentação, que trazem estes indicadores apenas por tipo de material empregado e tipo de conexões. Quanto ao consumo unitário de materiais, o método simplificado permite o prognóstico das quantidades de tubos e conexões tendo-se como variáveis de entrada o número de apartamentos-tipo por pavimento e sua respectiva área. O prognóstico destas quantidades, utilizando-se o método analítico, é feito com base no número e tipo de ambientes molháveis existentes no apartamento-tipo e no número de pontos de consumo/captação de água destes, além de equações elaboradas a partir da observação das concepções dos sistemas nos projetos analisados. Os métodos de prognóstico do consumo unitário de materiais foram aplicados a um caso real e a diferença entre as quantidades de tubos e conexões levantadas em projeto e as quantidades prognosticadas foi de $16 \%$ (tubos) e $22 \%$ (conexões), para o método simplificado, e $1 \%$ (tubos) e $4 \%$ (conexões), para o método analítico, indicando a aplicabilidade dos métodos propostos, para estes sistemas. A diferença entre a quantidade de mãode-obra (homens-hora) prognosticada utilizando-se o TCPO (2003) e a prognosticada utilizando o método proposto foi de $71 \%$, indicando a necessidade de um maior aprofundamento na exploração dos indicadores de produtividade da mão-de-obra na execução destes sistemas.

Palavras-chave: Produtividade da mão-de-obra. Consumo unitário de materiais. Orçamento. 


\section{Abstract}

The objective of this work is to elaborate a method aimed at evaluating the labour productivity in the execution of hydraulic systems and the unitary consumption of materials in these systems in two distinct moments: at the undertaking viability phase (simplified method) and at the architecture project phase (analytical method). The concepts that guided the elaboration of the proposed method involving conceptions on labour productivity, unitary consumption of materials and building systems will be presented. Besides these theoretical concepts, the detailing of the collection method and data processing for the evaluation of these indices will be performed, which include from the data collection planning, the data collection itself to the data processing. The results on labour productivity correspond to the survey of these parameters in four building sites in the state of São Paulo, while those on the unitary consumption of materials are a result of analysis and survey of information from 12 hydraulic systems of multiple-pavement residential buildings. The evaluation of labour productivity indices considering tasks and subtasks inherent to the execution of building systems with different effort levels is one of the contributions of this research, unlike budgeting handbooks that bring these parameters only in terms of the type of material and connections employed. Regarding to the unitary consumption of materials, the simplified method allows estimating the quantity of pipes and connections, considering the type and number of apartments per floor and their respective area as input variables. The prognostic of these quantities using the analytical method is performed based on the number and type of rooms provided with hydraulic building systems in the apartment and on the type, number of water consumption/intake points of these apartments, as well as on equations elaborated from the observation of conceptions in the projects analyzed. The proposed methods for unitary consumption of materials were applied to a real case and the difference between the quantity of pipes and connections measured and predicted was $16 \%$ (pipes) and $22 \%$ (connections), for the simplified method, and 1\% (pipes) and 4\% (connections) for the analytical method, validating the proposed methods for these systems. The difference between labour employed (man-hour) predicted using budgeting handbooks and those predicted using the proposed method was $71 \%$, indicating the need of further analysis of labour productivity indices in the hydraulic building systems.

Keywords: Labour productivity. Unitary consumption of materials. Budget. 


\section{Lista de Figuras}

\section{VOLUME 1}

\section{CAPÍTULO 1}

Figura 1.1 Etapas da Metodologia de Pesquisa

Figura 1.2 Etapas do Método de Pesquisa

\section{CAPÍTULO 2}

Figura 2.1 Produtividade da mão-de-obra (SOUZA, 2001)

Figura 2.2 Representação gráfica do Modelo dos Fatores. Fonte: SOUZA (1996)

Figura 2.3 Exemplos das diferentes naturezas das perdas: (a) entulho na execução de sistemas prediais; (b) incorporação de argamassa para embutir as tubulações; (c) material faltante na entrega de areia

\section{CAPÍTULO 3}

Figura 3.1 Classificação dos sistemas prediais em função do tipo de insumo/serviço requerido pelos usuários

Figura 3.2 Classificação do sistema predial de água fria em função do tipo de abastecimento: (a) Sistema direto; (b) sistema indireto (adaptado de ILHA; GONÇALVES, 1996)

Figura 3.3 Sistema de abastecimento direto: (a) sem bombeamento (SD-S); (b) com bombeamento (SD-B Booster) (adaptado de ILHA; GONÇALVES, 1996)

Figura 3.4 Sistema indireto: (a) com uso de reservatório superior (SI-G-RS); (b) com bombeamento da água diretamente da rede pública de abastecimento ao reservatório superior (SI-G-RS/B); (c) contendo reservatórios inferior e superior e dispositivo de bombeamento da água entre os mesmos (SI-GRS/RI) (adaptado de ILHA; GONÇALVES, 1996)

Figura 3.5 Sistema indireto hidropneumático: (a) sem bombeamento (SI-H); (b) com bombeamento (SI-H-B); (c) com bombeamento e reservatório inferior (SI-HB/RI) (adaptado de ILHA; GONÇALVES, 1996)

Figura 3.6 Ramais externo e interno e seus componentes (TESIS, 2003)

Figura 3.7 Corte: reservatório inferior (TESIS, 2003) 
Figura 3.8 Reservatório superior (TESIS, 2003)

$\begin{array}{lll}\text { Figura } 3.9 & \text { Reservatório inferior e as instalações elevatórias } & 068\end{array}$

$\begin{array}{lll}\text { Figura 3.10 Tipos de barrilete: a) concentrado b) ramificado } & \mathbf{0 7 0}\end{array}$

Figura 3.11 Ramal e sub-ramais (GONÇALVES, 2007) 072

Figura 3.12 Esquema vertical de um sistema predial de combate a incêndio: hidrantes $\mathbf{0 8 1}$ (GONÇALVES, 2007)

Figura 3.13 SPES convencional dotado de ventilação secundária (Planta e elevação) $\quad \mathbf{0 8 4}$

Figura 3.14 Válvulas de admissão de ar: a) Válvula Max-Vent ${ }^{\circledR}$; b) Válvula Mini-Vent ${ }^{\circledR} \quad \mathbf{0 8 5}$ (AMORIM, 2006)

Figura 3.15 Partes constituintes do sistema predial de esgoto sanitário (GONÇALVES, 2007)

Figura 3.16 Zonas de sobrepressão segundo a NBR 8160 (ABNT, 1999)

Figura 3.17 Subsistema de ventilação primária (TESIS, 2007) 090

Figura 3.18 Comparação entre a estrutura molecular do polietileno normal e do 097 polietileno reticulado (PEX) - (PEX do Brasil, 2005)

\section{CAPÍTULO 4}

Figura 4.1 Etapas da coleta de dados e respectivas atividades

Figura 4.2 Planta do sistema predial de esgoto sanitário de um ambiente molhável onde se pode verificar o tipo e número de conexões existentes

Figura 4.3 Divisão dos sistemas prediais de suprimento de água fria e água quente

Figura 4.4 Divisão dos sistemas prediais de suprimento de gás e de prevenção e combate a incêndios

Figura 4.5 Divisão dos sistemas prediais de coleta de esgoto sanitário e águas pluviais

Figura 4.6 Exemplo de trecho de tubulação com mais de uma conexão em uma de suas extremidades: (a) tubo de esgoto sanitário delimitado por duas conexões em cada extremidade; (b) registro de gaveta e o uso de adaptadores para junção com o trecho de tubulação

Figura 4.7 Exemplo de isométrica com ênfase nas conexões

Figura 4.8 Exemplo de planilha eletrônica para a quantificação do comprimento dos trechos de tubulação, número de conexões e diâmetro 
Figura 4.9 Exemplo de elaboração de planilhas de coleta a partir das planilhas "Fonte"

Figura 4.10 Divisão da execução dos sistemas de suprimento de água fria e água

Figura 4.11 Divisão da execução dos sistemas de suprimento gás e prevenção e combate a incêndios em tarefas e subtarefas

Figura 4.12 Divisão da execução dos sistemas de esgoto sanitário e águas pluviais em tarefas e subtarefas

Figura 4.13 Esquema geral das planilhas para quantificação dos serviços executados no canteiro de obras

Figura 4.14 Exemplo de planilha para anotação do serviço ou suas respectivas tarefas e subtarefas durante o dia de trabalho

Figura 4.15 Exemplo de utilização de argumentos matriciais no processamento dos dados

Figura 4.16 Fluxograma para obtenção do indicador de produtividade da mão-de-obra a partir das planilhas "Fonte", "Coleta em Obra" e de "Quantitativo de Projeto"

Figura 4.17 Fluxograma para a obtenção do consumo unitário a partir das planilhas "Fonte"

\section{CAPÍTULO 5}

Figura 5.1 Vista Geral da obra SP0101

Figura 5.2 Vista Geral da obra SP0201

Figura 5.3 Vista Geral da obra SP0301

Figura 5.4 Vista Geral da obra SP0601

Figura 5.5 Vista Geral da obra SP0701

Figura 5.6 Vista Geral da obra SP0801

Figura 5.7 Estocagem dos componentes utilizados na execução dos sistemas prediais:

(a) Estoque de tubos - SP0101; (b) Estoque de tubos - SP0201; (c)

Estoque de tubos - SP0301; (d) Estoque de conexões - SP0401

Figura 5.8 Sobras de tubos - SP0101: (a) PVC; (b) Cobre

Figura 5.9 Marcação e corte das paredes para embutimento das instalações - SP0101:

(a) e (b) execução do risco no prumo; (c) execução do corte das paredes;

(d) execução dos rasgos nas paredes

Figura 5.10 Produção de kits de instalações - SP0101: (a) operário trabalhando na bancada na produção de kits (b) e (c) kits produzidos e estocados em sala reservada 
Figura 5.11 Execução das prumadas - SP0101: (a) vista das prumadas do shaft da área de serviço (b) vista das prumadas do shaft do hall de serviço com detalhe para a proteção entre a braçadeira e as tubulações de cobre; (c) Prumadas fixadas e chumbadas no shaft

Figura 5.12 Execução dos ramais de distribuição de água fria e água quente - SP0101: (a) tubulações fixadas junto à laje de teto do apartamento (b) tubulações posicionadas sobre a alvenaria para posterior montagem; (c) e (d) detalhe da fixação das tubulações na laje de teto do apartamento

Figura 5.13 Execução dos ramais e sub-ramais de água fria e água quente nos rasgos das paredes (kits) - SP0101; (a) nivelamento e aprumo do kit na parede (b) exemplo de um kit chumbado na parede

Figura 5.14 Execução do ramal de esgoto - SP0101: (a) ramal de esgoto embutido na parede; (b) passante para execução do ramal de esgoto junto ao pilar

Figura 5.15 Execução dos tubos de queda (esgoto, águas pluviais) e colunas de ventilação - SP0101: (a) tubos de queda fixados junto ao perfil metálico (b) vista das tubulações de esgoto do shaft da área de serviço

Figura 5.16 Execução dos ramais de esgoto - SP0101: (a) fixação do pino junto à laje; (b) fita Walsywa já colocada sobre o ralo sifonado; (c) colocação da fita Walsywa junto à tubulação de esgoto; (d) vista geral dos ramais de esgoto já devidamente fixados

Figura 5.17 Chumbamento das tubulações nas paredes - SP0201: (a) verificação do nível do trecho de tubulação (b) verificação do prumo do trecho de tubulação

Figura 5.18 Produção de kits - SP0201: (a) e (b) bancada improvisada

Figura 5.19 Ramais de distribuição de água fria - SP0201: (a) sobre a última fiada de alvenaria; (b) e (c) sob a laje de teto; (d) sob a laje de teto, porém fixadas com braçadeiras

Figura 5.20 Ramais e sub-ramais de água fria e água quente - SP0201: (a) e (b) ramais e sub-ramais fixados provisoriamente nos rasgos das paredes; (c) detalhe da fixação provisória da tubulação de água quente; (d) kit de ramal e subramal de água quente e água quente fixado provisoriamente nos rasgos da parede

Figura 5.21 Ramais de esgoto sob a laje de teto - SP0201: (a) e (b) ramais de esgoto dos banheiros das suítes

Figura 5.22 Ramais de esgoto embutidos nas paredes - SP0201: (a) cozinha; (b)

Figura 5.23 Produção de kits - SP0301: (a) bancada localizada no $1^{\circ}$ subsolo; (b) esboço dos kits a serem produzidos

Figura 5.24 Execução das prumadas - SP0301: (a) operário lixando o topo da tubulação; (b) operário colocando o tubo na conexão; (c) operário realizando a solda entre a conexão e o tubo

Figura 5.25 Ramais de distribuição de água fria e água quente - SP0301: (a) fixação do piso com rosca para montagem do suporte das tubulações; (b) montagem do ramal de distribuição água fria e água quente, (c) detalhe da solda da tubulação com a conexão, com destaque para o suporte utilizado nesta obra 
Figura 5.26 Ramais de água fria e água quente - SP0301: (a) ramais destinados à condução de água fria (direita) e água quente (esquerda) do ramal de distribuição aos ramais e sub-ramais que alimentam os pontos de consumo do ambiente; (b) sub-ramais de água fria e água quente de um dos banheiros das suítes

Figura 5.27 Abertura da laje e chumbamento dos passantes - SP0401: (a) estoque de tubos passantes; (b) locação e abertura de furo na laje; (c) estoque de anteparo de madeira compensada resinada; (d) tubos passantes chumbados

Figura 5.28 Execução dos ramais de distribuição de água fria: (a) ramal fixado por arame junto à laje; (b) ramal sem fixação junto à laje

Figura 5.29 Sub-ramal de água fria e ramal de esgoto - SP0401: (a) furo na laje para colocação das tubulações; (b) tubulações fixadas junto aos sarrafos presos à parede; (c) anteparo de madeira compensada para o chumbamento das tubulações; (d) tubulações chumbadas com argamassa de cimento (detalhe: barras de aço utilizada para sustentação do anteparo)

Figura 5.30 Execução dos tubos de queda de esgoto, colunas de ventilação e tubos de queda de águas pluviais - SP0401: (a) Posicionamento dos blocos de vermiculita na posição dos shafts antes da concretagem da laje; (b) abertura de furos para passagem das tubulações; (c) tubulações montadas no shaft

Figura 5.31 Execução dos ramais de esgoto - SP0401: (a) Ramais de esgoto do banheiro; (b) detalhe da fixação da tubulação na laje

\section{VOLUME 2}

\section{CAPÍTULO 8}

Figura 8.1 Valores de metros de tubulação e número de conexões por área de apartamento-tipo - prognóstico: prumadas de água fria

Figura 8.2 Valores de metros de tubulação e número de conexões por área de apartamento-tipo - prognóstico: ramal de distribuição de água fria

Figura 8.3 Valores de metros de tubulação e número de conexões por área de apartamento-tipo - prognóstico: ramais e sub-ramais de água fria

Figura 8.4 Valores de metros de tubulação e número de conexões por área de apartamento-tipo - prognóstico: ramal de distribuição de água quente

Figura 8.5 Valores de metros de tubulação e número de conexões por área de apartamento-tipo - prognóstico: ramais e sub-ramais de água quente

Figura 8.6 Valores de metros de tubulação e número de conexões por área de apartamento-tipo - prognóstico: prumadas de gás

Figura 8.7 Valores de metros de tubulação e número de conexões por área de apartamento-tipo - prognóstico: ramal de distribuição de gás

Figura 8.8 Valores de metros de tubulação e número de conexões por área de apartamento-tipo - prognóstico: ramais e sub-ramais de gás 
Figura 8.9 Valores de metros de tubulação e número de conexões por área de

Figura 8.10 Valores de metros de tubulação e número de conexões por área de apartamento-tipo - prognóstico: tubos de queda de esgoto

Figura 8.11 Valores de metros de tubulação e número de conexões por área de apartamento-tipo - prognóstico: colunas de ventilação

Figura 8.12 Valores de metros de tubulação e número de conexões por área de apartamento-tipo - prognóstico: ramais de esgoto

Figura 8.13 Valores de metros de tubulação e número de conexões por área de apartamento-tipo - prognóstico: tubos de queda de águas pluviais

Figura 8.14 Valores de metros de tubulação e número de conexões por área de apartamento-tipo - prognóstico: ramais de águas pluviais

Figura 8.15 Exemplo de determinação do número de conjuntos de ambientes molháveis atendidos pelo ramal de distribuição de água fria

Figura 8.16 Faixa de valores de número de conexões por metro de tubulação - ramal de distribuição de água fria

Figura 8.17 Faixa de valores de número de conexões por metro de tubulação - ramal de distribuição de água quente

Figura 8.18 Faixa de valores de número de conexões por metro de tubulação - ramal de retorno de água quente

Figura 8.19 Exemplo de faixa de valores para RUP Potencial e $\triangle R U P_{\text {Cumulativa - Potencial }}$ subtarefa "Montagem e Fixação dos Ramais de Esgoto sob a laje 


\section{Lista de Tabelas}

\section{VOLUME 1}

\section{CAPÍTULO 1}

Tabela 1.1 Classificação da pesquisa desenvolvida nesta tese

Tabela 1.2 Relação de obras e projetos de sistemas prediais hidráulicos analisados

\section{CAPÍTULO 2}

Tabela 2.1 Exemplo de cálculo das RUP's: execução de prumadas de cobre

042

\section{CAPÍTULO 3}

Tabela 3.1 Tipos de sistemas prediais em função do insumo e/ou serviço requerido pelos usuários (GONÇALVES, 1994)

Tabela 3.2 Parâmetros para escolha do tipo de sistema predial de água fria GONÇALVES (2007)

Tabela 3.3 Elementos do sistema predial de suprimento de água fria

Tabela 3.4 Propriedades do GNP, GLP e gás de nafta (AMORIM, 2006)

Tabela 3.5 Vantagens na utilização da cada gás (AMORIM, 2001)

Tabela 3.6 Elementos do sistema predial de esgoto sanitário

Tabela 3.7 Principais elementos do subsistema de coleta e transporte de esgoto sanitário (NBR 8160; ABNT, 1999)

Tabela 3.8 Materiais empregados nos tubos e conexões utilizados nos sistemas prediais

Tabela 3.9 Classes dos tubos de cobre e seus respectivos usos 


\section{CAPÍTULO 5}

Tabela 5.1 Características gerais das edificações

Tabela 5.2 Características gerais do pavimento-tipo/apartamento-tipo

Tabela 5.3 Tipos de sistemas prediais existentes nas obras analisadas e os materiais empregados

Tabela 5.4 Resumo das características do sistema predial de suprimento de água fria das obras analisadas

Tabela 5.5 Resumo das características do sistema predial de suprimento de água quente das obras analisadas

Tabela 5.6 Resumo das características do sistema predial de suprimento de gás das obras analisadas

Tabela 5.7 Resumo das características do sistema predial de esgoto sanitário das

Tabela 5.8 Resumo das características do sistema predial de escoamento de águas pluviais das obras analisadas

Tabela 5.9 Composição da equipe de trabalho - SP0101

Tabela 5.10 Composição da equipe de trabalho - SP0201

Tabela 5.11 Composição da equipe de trabalho - SP0301

Tabela 5.12 Composição da equipe de trabalho - SP0401

\section{CAPÍTULO 6}

Tabela 6.1 Metros de tubos por área de apartamento-tipo: prumadas de água específicas a cada apartamento

Tabela 6.2 Metros de tubos por área de apartamento-tipo: prumadas de água fria comuns aos apartamentos

Tabela 6.3 Metros de tubos por área de apartamento-tipo: ramal de distribuição de água fria

Tabela 6.4 Metros de tubos por área de apartamento-tipo: ramais e sub-ramais de água fria

Tabela 6.5 Metros de tubos por área de apartamento-tipo: sistema predial de

Tabela 6.6 Metros de tubos por área de apartamento-tipo: sistema predial de suprimento de gás 
Tabela 6.7 Metros de tubos por área de apartamento-tipo e número de conexões por metro de tubulação: sistema predial de prevenção e combate a incêndios

Tabela 6.8 Metros de tubos por área de apartamento-tipo: tubos de queda e coluna de ventilação

Tabela 6.9 Metros de tubos por área de apartamento-tipo: ramais de esgoto e de

Tabela 6.10 Metros de tubos por área de apartamento-tipo: tubos de queda

Tabela 6.11 Metros de tubos por área de apartamento-tipo: resumo dos tubos de queda e ramais

Tabela 6.12 Número de conexões por área de apartamento-tipo: prumadas de água fria específicas a cada apartamento

Tabela 6.13 Número de conexões por área de apartamento-tipo: prumadas de água fria comuns aos apartamentos

Tabela 6.14 Número de conexões por área de apartamento-tipo: ramal de distribuição de água fria

Tabela 6.15 Número de conexões por área de apartamento-tipo: ramais e sub-ramais de água fria

Tabela 6.16 Número de conexões por área de apartamento-tipo - sistema predial de suprimento de água quente

Tabela 6.17 Número de conexões por por área de apartamento-tipo: sistema predial de suprimento de gás

Tabela 6.18 Número de conexões por área de apartamento-tipo: sistema predial de prevenção e combate a incêndios

Tabela 6.19 Número de conexões por área de apartamento-tipo: tubos de queda e coluna de ventilação

Tabela 6.20 Número de conexões por área de apartamento-tipo: ramais de esgoto e de ventilação

Tabela 6.21 Número de conexões por área de apartamento-tipo: tubos de queda

Tabela 6.22 Número de conexões por área de apartamento-tipo: resumo dos tubos de queda e ramais

Tabela 6.23 Indicadores de consumo e fatores potencialmente influenciadores: ramal de distribuição de água fria

Tabela 6.24 Indicadores de consumo e fatores potencialmente influenciadores: ramais e sub-ramais de água fria - banheiros das suítes e banheiro social

Tabela 6.25 Indicadores de consumo de materiais e fatores potencialmente influenciadores: ramais e sub-ramais de água fria - banheiro de empregada 
Tabela 6.26 Indicadores de consumo de materiais e fatores potencialmente

Tabela 6.27 Indicadores de consumo de materiais e fatores potencialmente

Tabela 6.28 Indicadores de consumo de materiais e fatores potencialmente

Tabela 6.29 Indicadores de consumo de materiais e fatores potencialmente

Tabela 6.30 Indicadores de consumo e fatores potencialmente influenciadores: ramal de distribuição de água quente

Tabela 6.31 Indicadores de consumo e fatores potencialmente influenciadores: ramal de retorno de água quente

Tabela 6.32 Indicadores de consumo e fatores potencialmente influenciadores: ramais e sub-ramais de água quente - banheiros das suítes e banheiro social

Tabela 6.33 Indicadores de consumo de materiais e fatores potencialmente influenciadores: ramais e sub-ramais de água quente - banheiro de empregada e lavabo

Tabela 6.34 Indicadores de consumo de materiais e fatores potencialmente influenciadores: ramais e sub-ramais de água quente - cozinha

Tabela 6.35 Indicadores de consumo de materiais e fatores potencialmente influenciadores: ramal de distribuição de gás

Tabela 6.36 Indicadores de consumo de materiais: ramais e sub-ramais de gás - área de serviço

Tabela 6.37 Indicadores de consumo de materiais: ramais e sub-ramais de gás cozinha

Tabela 6.38 Indicadores de consumo de materiais: ramais de esgoto e de ventilação banheiros das suítes e banheiro social

Tabela 6.39 Indicadores de consumo de materiais: ramais de esgoto e de ventilação banheiro de empregada

Tabela 6.40 Indicadores de consumo de materiais: ramais de esgoto e de ventilação lavabo

Tabela 6.41 Indicadores de consumo de materiais: ramais de esgoto e de ventilação cozinha

Tabela 6.42 Indicadores de consumo de materiais: ramais de esgoto e de ventilação área de serviço

Tabela 6.43 Indicadores de consumo de materiais: ramais de esgoto e de ventilação terraço da sala de estar 
Tabela 6.45 Estatísticas gerais (por área): sistema predial de suprimento de água fria

Tabela 6.46 Estatísticas gerais (por área): sistema predial de suprimento de água quente

Tabela 6.47 Estatísticas gerais (por área): sistema predial de suprimento de gás

Tabela 6.48 Estatísticas gerais (por área): sistema predial prevenção e combate a incêndios

Tabela 6.49 Estatísticas gerais (por área): sistema predial de esgoto sanitário

Tabela 6.50 Estatísticas gerais (por área): sistema predial de escoamento de águas

Tabela 6.51 Estatísticas gerais (m/ponto; m/ambiente; conexões $/ \mathrm{m})$ ): sistema predial de suprimento de água fria

Tabela 6.52 Estatísticas gerais ( $\mathrm{m} /$ ponto; $\mathrm{m} /$ ambiente; conexões $/ \mathrm{m}$ ): sistema predial de suprimento de água quente

Tabela 6.53 Estatísticas gerais ( $\mathrm{m} /$ ponto; $\mathrm{m} / \mathrm{ambiente}$; conexões $/ \mathrm{m}$ ): sistema predial de suprimento de gás

Tabela 6.54 Estatísticas gerais ( $\mathrm{m} /$ ponto; conexões $/ \mathrm{m}$ ): sistema predial de esgoto sanitário - ramais de esgoto e de ventilação

Tabela 6.55 Estatísticas gerais ( $\mathrm{m} /$ ponto; conexões $/ \mathrm{m}$ ): sistema predial de escoamento de águas pluviais - ramais

\section{VOLUME 2}

\section{CAPÍTULO 7}

Tabela 7.1 Resumo das quantidades de Homens-hora e quantidades de serviços Obra SP0101

Tabela 7.2 RUP Diária, RUP Cumulativa e RUP Potencial para a execução da tarefa

"Corte de Paredes" - Obra SP0101

Tabela 7.3 RUP Diária, RUP Cumulativa e RUP Potencial para a execução da tarefa "Rasgo de Paredes" - Obra SP0101

Tabela 7.4 RUP Diária, RUP Cumulativa e RUP Potencial para a execução da tarefa "Produção de kits - cobre" - Obra SP0101

Tabela 7.5 RUP Diária, RUP Cumulativa e RUP Potencial para a execução da tarefa "Prumadas - cobre" - Obra SP0101

Tabela 7.6 RUP Diária, RUP Cumulativa e RUP Potencial para a execução da tarefa "Ramais de distribuição - cobre" - Obra SP0101

Tabela 7.7 RUP Diária, RUP Cumulativa e RUP Potencial para a execução da tarefa "Ramais/sub-ramais - paredes in loco - cobre" - Obra SP0101 
Tabela 7.8 RUP Diária, RUP Cumulativa e RUP Potencial para a execução da tarefa

Tabela 7.9 RUP Diária, RUP Cumulativa e RUP Potencial para a execução da tarefa

"Ramais/sub-ramais - sob a laje in loco - cobre" - Obra SP0101

Tabela 7.10 RUP Diária, RUP Cumulativa e RUP Potencial para a execução da tarefa

"Tubos de queda/colunas de ventilação esgoto/tubos de queda - águas pluviais - PVC" - Obra SP0101

Tabela 7.11 RUP Diária, RUP Cumulativa e RUP Potencial para a execução da tarefa "Ramais de esgoto/águas pluviais - sob a laje - PVC" - Obra SP0101

Tabela 7.12 RUP Diária, RUP Cumulativa e RUP Potencial para a execução da tarefa "Ramais de esgoto - paredes" - Obra SP0101

Tabela 7.13 Resumo das quantidades de Homens-hora e quantidades de serviços Obra SP0201

Tabela 7.14 RUP Diária, RUP Cumulativa e RUP Potencial para a execução da tarefa "Fixação da tubulação nas paredes (argamassa)" - Obra SP0201

Tabela 7.15 RUP Diária, RUP Cumulativa e RUP Potencial para a execução da tarefa "Produção de kits - PVC" - Obra SP0201

Tabela 7.16 RUP Diária, RUP Cumulativa e RUP Potencial para a execução da tarefa "Produção de kits - Cobre" - Obra SP0201

Tabela 7.17 RUP Diária, RUP Cumulativa e RUP Potencial para a execução da tarefa "Ramais de distribuição - PVC" - Obra SP0201

Tabela 7.18 RUP Diária, RUP Cumulativa e RUP Potencial para a execução da tarefa "Ramais de distribuição - Cobre" - Obra SP0201

Tabela 7.19 RUP Diária, RUP Cumulativa e RUP Potencial para a execução da tarefa "Ramais/sub-ramais - paredes in loco - PVC" - Obra SP0201

Tabela 7.20 RUP Diária, RUP Cumulativa e RUP Potencial para a execução da tarefa "Ramais/sub-ramais - paredes in loco - Cobre" - Obra SP0201

Tabela 7.21 RUP Diária, RUP Cumulativa e RUP Potencial para a execução da tarefa "Ramais/sub-ramais - paredes kits - PVC/Cobre" - Obra SP0201

Tabela 7.22 RUP Diária, RUP Cumulativa e RUP Potencial para a execução da tarefa "Ramais de esgoto/águas pluviais - sob a laje de teto - PVC" - Obra SP0201

Tabela 7.23 RUP Diária, RUP Cumulativa e RUP Potencial para a execução da tarefa "Ramais de esgoto/águas pluviais - paredes - PVC" - Obra SP0201

Tabela 7.24 Resumo das quantidades de Homens-hora e quantidades de serviços Obra SP0301

Tabela 7.25 RUP Diária, RUP Cumulativa e RUP Potencial para a execução da tarefa "Corte e rasgo de paredes" - Obra SP0301 
Tabela 7.27 RUP Diária, RUP Cumulativa e RUP Potencial para a execução da tarefa "Prumadas - cobre" - Obra SP0301

Tabela 7.28 RUP Diária, RUP Cumulativa e RUP Potencial para a execução da tarefa "Ramais de distribuição - Fixação" - Obra SP0301

Tabela 7.29 RUP Diária, RUP Cumulativa e RUP Potencial para a execução da tarefa "Ramais de distribuição - Montagem - Cobre" - Obra SP0301

Tabela 7.30 RUP Diária, RUP Cumulativa e RUP Potencial para a execução da tarefa "Ramais/sub-ramais - tetos - Cobre" - Obra SP0301

Tabela 7.31 RUP Diária, RUP Cumulativa e RUP Potencial para a execução da tarefa "Ramais/sub-ramais - paredes in loco - Cobre - Cozinha/AS" - Obra SP0301

Tabela 7.32 RUP Diária, RUP Cumulativa e RUP Potencial para a execução da tarefa "Ramais/sub-ramais - paredes in loco - Cobre - sanitários" - Obra SP0301

Tabela 7.33 RUP Diária, RUP Cumulativa e RUP Potencial para a execução da tarefa "Ramais/sub-ramais - paredes kits - Cobre - sanitários" - Obra SP0301

Tabela 7.34 RUP Diária, RUP Cumulativa e RUP Potencial para a execução da tarefa "Tubos de queda/colunas de ventilação esgoto/tubos de queda - águas pluviais - PVC" - Obra SP0301

Tabela 7.35 RUP Diária, RUP Cumulativa e RUP Potencial para a execução da tarefa "Ramais de esgoto/águas pluviais - sob a laje - PVC" - Obra SP0301

Tabela 7.36 RUP Diária, RUP Cumulativa e RUP Potencial para a execução da tarefa "Ramais de esgoto/águas pluviais - paredes - PVC" - Obra SP0301

Tabela 7.37 Resumo das quantidades de Homens-hora e quantidades de serviços Obra SP0401

Tabela 7.38 RUP Diária, RUP Cumulativa e RUP Potencial para a execução da tarefa "Abertura de passantes" - Obra SP0401

Tabela 7.39 RUP Diária, RUP Cumulativa e RUP Potencial para a execução da tarefa "Fixação de passantes" - Obra SP0401

Tabela 7.40 RUP Diária, RUP Cumulativa e RUP Potencial para a execução da tarefa "Abertura de shafts" - Obra SP0401

Tabela 7.41 RUP Diária, RUP Cumulativa e RUP Potencial para a execução da tarefa "Ramais de distribuição - PVC - Montagem" - Obra SP0401

Tabela 7.42 RUP Diária, RUP Cumulativa e RUP Potencial para a execução da tarefa "Ramais/sub-ramais água fria - sob a laje - PVC" - Obra SP0401

Tabela 7.43 RUP Diária, RUP Cumulativa e RUP Potencial para a execução da tarefa "Tubos de queda/colunas de ventilação esgoto/tubos de queda - águas pluviais - PVC" - Obra SP0401

Tabela 7.44 RUP Diária, RUP Cumulativa e RUP Potencial para a execução da tarefa "Ramais de esgoto/águas pluviais - sob a laje - PVC" - Obra SP0401 
Tabela 7.47 RUP: Abertura de shafts e passantes, chumbamento de tubulações, corte e rasgo de paredes

Tabela 7.48 RUP: produção de Kits

Tabela 7.49 RUP: prumadas

Tabela 7.50 ramais de distribuição

Tabela 7.51 RUP: ramais e sub-ramais de água fria, água quente e gás embutidos na

Tabela 7.52 RUP: ramais e sub-ramais de água fria e água quente sob a laje e ramais de gás embutidos no piso

Tabela 7.53 RUP: tubos de queda de esgoto e águas pluviais e colunas de ventilação de esgoto

Tabela 7.54 RUP: ramais de esgoto e de águas pluviais sob a laje

Tabela 7.55 RUP: ramais de esgoto embutidos na parede

\section{CAPÍTULO 8}

Tabela 8.1 Fatores de conteúdo: metros de tubulação por área de apartamento-tipo

Tabela 8.2 Fatores de conteúdo: metros de tubulação pelo número de pontos de consumo

Tabela 8.3 Fatores de conteúdo: número de conexões por metro de tubulação

Tabela 8.4 Fatores de conteúdo e contexto relacionado à RUP Potencial: execução do sistema de suprimento de água fria

Tabela 8.5 Definição do número de prumadas de água fria

Tabela 8.6 Metros de tubulação pelo número de ambientes atendidos pelo ramal de distribuição de água fria

Tabela 8.7 Número de pontos de consumo mínimo em cada ambiente- ramais e subramais de água fria

Tabela 8.8 Cálculo do número de pontos de consumo de água fria por ambiente

Tabela 8.9 Indicador de consumo metros de tubulação por número de pontos de consumo de água fria e número de conexões por metro de tubulação

Tabela 8.10 Definição do número de prumadas: única zona de pressão

Tabela 8.11 Definição do número de prumadas: duas zonas de pressão 
Tabela 8.12 Metros de tubulação de ramal de distribuição e de ramal de retorno pelo

Tabela 8.13 Número de pontos de consumo mínimo em cada ambiente - ramais e subramais de água quente

Tabela 8.14 Número de pontos de consumo de água quente por ambientes

Tabela 8.15 Indicador de consumo metros de tubulação por número de pontos de consumo de água quente e número de conexões por metro de tubulação

Tabela 8.16 Comprimento de tubulação e número de conexões por metro de tubulação ramal de distribuição de gás

Tabela 8.17 Número de pontos de consumo de gás por ambiente

Tabela 8.18 Indicador de consumo metros de tubulação por número de pontos de

Tabela 8.19 Definição do número de tubos de queda de esgoto

Tabela 8.20 Definição do número de conexões - tubo de queda

Tabela 8.21 Número de pontos de captação - sistema predial de esgoto sanitário

Tabela 8.22 Cálculo do número de pontos de captação de esgoto por ambiente

Tabela 8.23 Indicador de consumo metros de tubulação por número de pontos de captação de esgoto e número de conexões por metro de tubulação

Tabela 8.24 Definição do número de tubos de queda: águas pluviais

Tabela 8.25 Definição do número de conexões - tubo de queda de águas pluviais

Tabela 8.26 Cálculo do número de pontos de captação de águas pluviais por ambiente

Tabela 8.27 Indicador de consumo metros de tubulação por número de pontos de

Tabela 8.28 Faixas de valores de RUP Potencial e $\Delta$ RUP Cumulativa - Potencial para as diversas subtarefas inerentes à execução dos sistemas prediais hidráulicos

Tabela 8.29 Características gerais - SP1101

Tabela 8.30 Características gerais do pavimento-tipo/apartamento-tipo - SP1101

Tabela 8.31 Áreas dos ambientes molháveis - SP1101

Tabela 8.32 Características do sistema predial de suprimento de água fria -SP1101

Tabela 8.33 características do sistema predial de suprimento de água quente - SP1101

Tabela 8.34 Características do sistema predial de suprimento de gás - SP1101 
Tabela 8.35 Características do sistema predial de esgoto sanitário - SP1101

Tabela 8.36 Características do sistema predial de escoamento de águas pluviais -

Tabela 8.37 Número de pontos de consumo e de captação - SP1101

Tabela 8.38 Quantidade de tubos e conexões: sistema predial de suprimento de água fria - SP1101

Tabela 8.39 Quantidade de tubos e conexões: sistema predial de suprimento de água quente - SP1101

Tabela 8.40 Quantidade de tubos e conexões: sistema predial de suprimento de gás SP1101

Tabela 8.41 Quantidade de tubos e conexões: sistema predial de prevenção e combate a incêndios - SP1101

Tabela 8.42 Quantidade de tubos e conexões: sistema predial de coleta de esgoto SP1101

Tabela 8.43 Quantidade de tubos e conexões: sistema predial de coleta de águas pluviais - SP1101

Tabela 8.44 Comparação entre o comprimento real de tubos e número de conexões e os obtidos utilizando o método de prognóstico simplificado - Sistema predial de suprimento de água fria

Tabela 8.45 Comparação entre o comprimento real de tubos e número de conexões e os obtidos utilizando o método de prognóstico simplificado - Sistema predial de suprimento de água quente

Tabela 8.46 Comparação entre o comprimento real de tubos e número de conexões e os obtidos utilizando o método de prognóstico simplificado - Sistema predial de suprimento de gás

Tabela 8.47 Comparação entre o comprimento real de tubos e número de conexões e os obtidos utilizando o método de prognóstico simplificado - Sistema predial de prevenção e combate a incêndios

Tabela 8.48 Comparação entre o comprimento real de tubos e número de conexões e os obtidos utilizando o método de prognóstico simplificado - Sistema predial de coleta de esgoto

Tabela 8.49 Comparação entre o comprimento real de tubos e número de conexões e os obtidos utilizando o método de prognóstico simplificado - Sistema predial de coleta de águas pluviais

Tabela 8.50 Comparação entre o comprimento real de tubos e o obtido utilizando o método de prognóstico analítico - Sistema predial de suprimento de água fria

Tabela 8.51 Comparação entre o número de conexões real e o obtido utilizando o método de prognóstico analítico - Sistema predial de suprimento de água fria 
Tabela 8.52 Comparação entre o comprimento real de tubos e o obtido utilizando o método de prognóstico analítico - Sistema predial de suprimento de água quente

Tabela 8.53 Comparação entre o número de conexões real e o obtido utilizando o método de prognóstico analítico - Sistema predial de suprimento de água quente

Tabela 8.54 Comparação entre o comprimento real de tubos e o obtido utilizando o método de prognóstico analítico - Sistema predial de suprimento de gás

Tabela 8.55 Comparação entre o número de conexões real e o obtido utilizando o método de prognóstico analítico - Sistema predial de suprimento de gás

Tabela 8.56 Comparação entre o comprimento real de tubos e o obtido utilizando o método de prognóstico analítico - Sistema predial de prevenção e combate a incêndios

Tabela 8.57 Comparação entre o número de conexões real e o obtido utilizando o método de prognóstico analítico - Sistema predial de prevenção e combate a incêndios

Tabela 8.58 Comparação entre o comprimento real de tubos e o obtido utilizando o método de prognóstico analítico - Sistema predial de coleta de esgoto

Tabela 8.59 Comparação entre o número de conexões real e o obtido utilizando o método de prognóstico analítico - Sistema predial de coleta de esgoto

Tabela 8.60 Comparação entre o comprimento real de tubos e o obtido utilizando o método de prognóstico analítico - Sistema predial de coleta de águas pluviais

Tabela 8.61 Comparação entre o número de conexões real e o obtido utilizando o método de prognóstico analítico - Sistema predial de coleta de águas pluviais

Tabela 8.62 Homens-hora demandados - método de prognóstico analítico - Shafts e passantes

Tabela 8.63 Homens-hora demandados - método de prognóstico analítico - Corte e rasgos de paredes

Tabela 8.64 Homens-hora demandados - método de prognóstico analítico - Sistema predial de suprimento de água fria

Tabela 8.65 Homens-hora demandados - método de prognóstico analítico - Sistema predial de suprimento de água quente

Tabela 8.66 Homens-hora demandados - método de prognóstico analítico - Sistema predial de suprimento de gás

Tabela 8.67 Homens-hora demandados - método de prognóstico analítico - Sistema predial de prevenção e combate a incêndios

Tabela 8.68 Homens-hora demandados - método de prognóstico analítico - Sistema predial de coleta de esgoto 
Tabela 8.69 Homens-hora demandados - método de prognóstico analítico - Sistema

predial de coleta de águas pluviais

Tabela 8.70 Homens-hora demandados - TCPO (2003) - Corte e rasgos de paredes

Tabela 8.71 Homens-hora demandados - TCPO (2003) - Sistema predial de suprimento de água fria

Tabela 8.72 Homens-hora demandados - TCPO (2003) - Sistema predial de suprimento de água quente

Tabela 8.73 Homens-hora demandados - TCPO (2003) - Sistema predial de suprimento de gás

Tabela 8.74 Homens-hora demandados - TCPO (2003) - Sistema predial de prevenção e combate a incêndios

Tabela 8.75 Homens-hora demandados - TCPO (2003) - Sistema predial de coleta de esgoto

Tabela 8.76 Homens-hora demandados - TCPO (2003) - Sistema predial de coleta de águas pluviais

Tabela 8.77 Metros de tubulação e número de conexões por tipo de sistema: comparação entre a quantidade levantada em projeto e a prognosticada utilizando o método simplificado

Tabela 8.78 Metros de tubulação e número de conexões por tipo de sistema: comparação entre quantidade levantada em projeto e a prognosticada utilizando o método analítico

Tabela 8.79 Quantidade de Homens-hora demandados por tipo de sistema: comparação entre a quantidade prognosticada utilizando o método proposto e a prognosticada utilizando o TCPO (2003)

\section{CAPÍTULO 9}

Tabela 9.1 Perdas de tubos de PVC (esgoto) - Obra SP0101

Tabela 9.2 Perdas de tubos de PVC (esgoto) - Obra SP0201

Tabela 9.3 Perdas de tubos de PVC (água fria) - Obra SP0201

Tabela 9.4 Perdas de tubos de cobre - Obra SP0101

Tabela 9.5 Perdas de tubos de cobre - Obra SP0201 


\section{SUMÁRIO}

\section{VOLUME 1}

CAPÍTULO 1

$\begin{array}{ll}\text { 1. INTRODUÇÃO } & 001\end{array}$

1.1 A importância da melhoria da produtividade no uso dos recursos físicos nos canteiros de obras

1.2 A importância do estudo da produtividade da mão-de-obra e do consumo unitário de materiais nos sistemas prediais hidráulicos

1.3 A necessidade de um método para o prognóstico da produtividade da mão-deobra e do consumo unitário de materiais nos sistemas prediais hidráulicos

1.4 Contexto do trabalho

1.5 Metodologia da pesquisa

1.5.1 Pesquisa científica

1.5.2 Método científico

1.5.3 Tema e formulação do problema de pesquisa

1.5.3.1 Tema de pesquisa

1.5.3.2 Problema de pesquisa

020

1.5.4 Hipótese

022

1.5.5 Objetivos

024

1.5.6 Classificação da pesquisa

1.5.7 Método de pesquisa

1.6 Estrutura do texto

2. PRODUTIVIDADE DA MÃO-DE-OBRA E CONSUMO UNITÁRIO DE MATERIAIS 
2.1.4 Classificação dos indicadores de produtividade da mão-de-obra

2.2 Aspectos conceituais relacionados a perdas e consumo unitário

2.2.1 Consumo unitário de materiais

042

2.2.2 Perdas de materiais

2.2.3 Classificação das perdas

045

2.2.3.1 Segundo sua forma de manifestação

045

2.2.3.2 Segundo o momento de incidência na etapa de Produção

2.2.3.3 Segundo suas causas

046

2.2.3.4 Segundo sua origem

047

2.3 Analogia entre os indicadores de produtividade da mão-de-obra e perdas de 047 materiais

\section{CAPÍTULO 3}

3. SISTEMAS PREDIAIS

049

3.1 Definição de sistemas prediais

3.2 Classificação dos sistemas prediais

053

3.3 Sistema predial de suprimento de água fria

055

3.3.1 Definição

055

3.3.2 Requisitos de desempenho

056

3.3.3 Classificação

3.3.3.1 Sistema de abastecimento direto

058

3.3.3.2 Sistema de abastecimento indireto

3.3.4 Escolha do tipo de sistema

062

3.3.5 Partes constituintes

063

3.3.5.1 Alimentação

064

3.3.5.2 Reservatórios

066

3.3.5.3 Distribuição interna

3.4 Sistema predial de suprimento de água quente

072

3.4.1 Definição

3.4.2 Requisitos de desempenho 
3.4.3.1 Quanto à abrangência de pontos de consumo abastecidos 074 simultaneamente

3.4.3.2 Quanto à fonte de energia para o aquecimento

3.4.3.3 Quanto à acumulação de água quente $\quad \mathbf{0 7 5}$

3.4.3.4 Sistemas integrados de aquecimento $\quad \mathbf{0 7 5}$

$\begin{array}{ll}\text { 3.4.4 Partes constituintes } & \mathbf{0 7 6}\end{array}$

$\begin{array}{ll}\text { 3.5 Sistema predial de suprimento de gás } & \mathbf{0 7 7}\end{array}$

$\begin{array}{ll}\text { 3.5.1 Definição } & \mathbf{0 7 7}\end{array}$

$\begin{array}{ll}3.5 .2 \text { Requisitos } & \mathbf{0 7 7}\end{array}$

$\begin{array}{ll}3.5 .3 \text { Tipo de gás } & \mathbf{0 7 8}\end{array}$

$\begin{array}{ll}\text { 3.6 Sistema predial de prevenção e combate a incêndios } & \mathbf{0 7 9}\end{array}$

3.7 Sistema predial de esgoto sanitário (SPES) 082

3.7.1 Definição 082

$\begin{array}{ll}\text { 3.7.2 Requisitos de desempenho } & \mathbf{0 8 2}\end{array}$

$\begin{array}{ll}\text { 3.7.3 Classificação } & 083\end{array}$

3.7.3.1 SPES convencional dotado de ventilação primária $\mathbf{0 8 3}$

3.7.3.2 SPES convencional dotado de ventilação primária e $\mathbf{0 8 3}$ secundária

3.7.3.3 SPES dotado de válvulas de admissão de ar 084

$\begin{array}{ll}\text { 3.7.4 Partes constituintes } & \mathbf{0 8 6}\end{array}$

3.7.4.1 Subsistema de coleta e transporte do esgoto sanitário 086

$\begin{array}{ll}\text { 3.7.4.2 Subsistema de ventilação } & \mathbf{0 8 9}\end{array}$

$\begin{array}{ll}\text { 3.8 Sistema predial de escoamento de águas pluviais } & 091\end{array}$

3.8.1 Definição $\quad 091$

$\begin{array}{ll}\text { 3.8.2 Requisitos de desempenho } & 091\end{array}$

$\begin{array}{lc}\text { 3.8.3 Partes constituintes } & 091\end{array}$

3.9 Materiais empregados nos componentes para os sistemas prediais 092

$\begin{array}{ll}3.9 .1 \mathrm{PVC} & 094\end{array}$ 


\section{MÉTODO DE COLETA E PROCESSAMENTO DOS DADOS}

4.1 Experiências obtidas e diretrizes a serem seguidas a partir do estudo piloto

4.1.1 Quantidade de serviço

4.2 Etapas do método de coleta e processamento dos dados

4.3 Planejamento da coleta de dados

4.3.2 Divisão dos sistemas prediais em subsistemas/elementos

4.3.4 Caracterização dos trechos quanto ao seu comprimento, número de conexões e diâmetro

4.3.5 Elaboração de planilhas de dados eletrônicas primárias (Planilhas "Fonte")

4.3.6 Divisão dos serviços em tarefas e subtarefas

4.3.7 Entendimento da forma de organização da produção

4.3.8 Elaboração de planilhas de coleta de dados no canteiro de obras

4.3.8.1 Quantidade de serviço executado

4.3.8.2 Homens-hora demandados para a execução dos serviços

4.4.1 Relativa ao cálculo da produtividade da mão-de-obra

4.4.1.2 Mapeamento inicial dos serviços 
4.5.1 Produtividade da mão-de-obra $\quad 131$

4.5.2 Consumo unitário de materiais $\quad 135$

4.5.3 Caracterização da edificação e dos sistemas prediais 136

$\begin{array}{ll}\text { CAPÍTULO } 5 & 137\end{array}$

5. ESTUDOS DE CASO

$\begin{array}{ll}\text { 5.1 Características gerais dos Estudos de Caso } & 138\end{array}$

$\begin{array}{ll}\text { 5.1.1 SP0101 } & 138\end{array}$

$\begin{array}{ll}5.1 .2 \text { SP0201 } & 139\end{array}$

$\begin{array}{ll}5.1 .3 \text { SP0301 } & 140\end{array}$

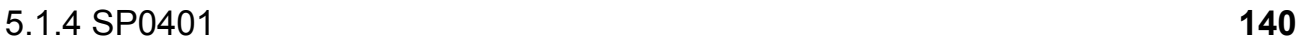

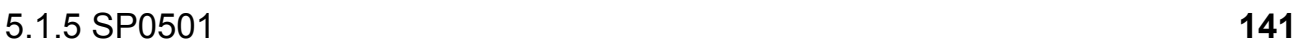

5.1.6 SP0601 141

5.1.7 SP0701 142

$\begin{array}{ll}5.1 .8 \mathrm{SP} 0702 & 143\end{array}$

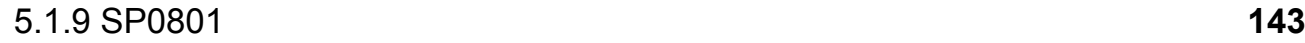

$\begin{array}{ll}\text { 5.1.10 SP0901 } & 144\end{array}$

$\begin{array}{lll}\text { 5.1.11 SP1001 } & 145\end{array}$

$\begin{array}{ll}5.1 .12 \text { SP1002 } & 145\end{array}$

5.1.13 Resumo 145

$\begin{array}{ll}\text { 5.2 Características dos sistemas prediais } & 150\end{array}$

5.2.1 Sistema predial de suprimento de água fria 150

$\begin{array}{ll}\text { 5.2.1.1 SP0101 } & 151\end{array}$

5.2.1.2 SP0201 153

$\begin{array}{ll}\text { 5.2.1.3 SP0301 } & 155\end{array}$

5.2.1.4 SP0401 157

$\begin{array}{ll}\text { 5.2.1.5 SP0501 } & 158\end{array}$

$\begin{array}{ll}\text { 5.2.1.6 SP0601 } & 159\end{array}$ 
5.2.1.8 SP0702 162

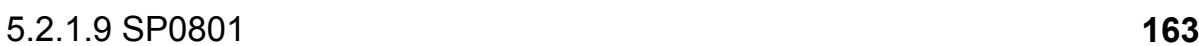

5.2.1.10 SP0901a e SP0901b 164

$\begin{array}{ll}\text { 5.2.1.11 SP1001 } & 165\end{array}$

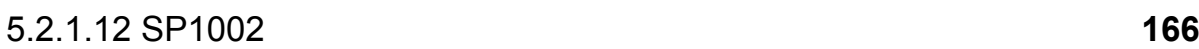

5.2.1.13 Resumo das características do sistema predial de 167 suprimento de água fria

$\begin{array}{ll}\text { 5.2.2 Sistema predial de suprimento de água quente } & \mathbf{1 7 0}\end{array}$

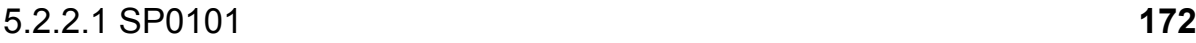

$\begin{array}{ll}\text { 5.2.2.2 SP0201 } & 173\end{array}$

$\begin{array}{ll}\text { 5.2.2.3 SP0301 } & 173\end{array}$

5.2.2.4 SP0501 e SP0801 174

$\begin{array}{ll}\text { 5.2.2.5 SP0601 } & 174\end{array}$

5.2.2.6 SP0701 e SP0702 175

$\begin{array}{ll}\text { 5.2.2.7 SP0901a e SP0901b } & 176\end{array}$

5.2.2.8 SP1001 e SP1002 176

$\begin{array}{ll}\text { 5.2.3 Sistema predial de suprimento de gás } & 177\end{array}$

5.2.4 Sistema predial de coleta de esgoto sanitário 179

5.2.5 Sistema predial de coleta de águas pluviais 183

5.2.6 Sistema predial prevenção e combate a incêndios 186

$\begin{array}{ll}\text { 5.3 Caracterização da execução dos serviços } & 187\end{array}$

$\begin{array}{ll}\text { 5.3.1 Estocagem e transporte } & 187\end{array}$

5.3.2 Método executivo 189

$\begin{array}{ll}\text { 5.3.2.1 SP0101 } & 189\end{array}$

$\begin{array}{ll}\text { 5.3.2.2 SP0201 } & 201\end{array}$

$\begin{array}{ll}\text { 5.3.2.3 SP0301 } 207 & 207\end{array}$

$\begin{array}{ll}\text { 5.3.2.4 SP0401 } & \mathbf{2 1 3}\end{array}$

$\begin{array}{ll}\text { 5.4 Composição das equipes de trabalho } & \mathbf{2 1 8}\end{array}$ 
5.4.2 SP0201 222

5.4 .3 SP0301 223
2

$\begin{array}{ll}\text { 5.4.4 SP0401 } & 225\end{array}$

$\begin{array}{ll}\text { CAPÍTULO } 6 & 227\end{array}$

6. RESULTADOS: CONSUMO UNITÁRIO DE MATERIAIS 227

$\begin{array}{ll}\text { 6.1 Metros de tubos por área de apartamento-tipo } & \mathbf{2 2 9}\end{array}$

6.1.1 Sistema predial de suprimento de água fria 229

6.1.1.1 Prumadas $\quad 229$

6.1.1.2 Ramal de distribuição $\quad 231$

6.1.1.3 Ramais e sub-ramais 232

6.1.2 Sistema predial de suprimento de água quente 233

6.1.3 Sistema predial de suprimento de gás $\quad 234$

6.1.4 Sistema predial de prevenção e combate a incêndios 235

6.1.5 Sistema predial de coleta de esgoto sanitário 236

6.1.5.1 Tubos de queda e colunas de ventilação 236

$\begin{array}{ll}\text { 6.1.5.2 Ramais } & 237\end{array}$

6.1.6 Sistema predial de coleta de águas pluviais $\quad 238$

$\begin{array}{ll}\text { 6.2 Número de conexões por área de apartamento-tipo } & \mathbf{2 4 0}\end{array}$

6.2.1 Sistema predial de suprimento de água fria $\quad \mathbf{2 4 0}$

6.2.1.1 Prumadas $\quad 240$

6.2.1.2 Ramal de distribuição $\quad 242$

6.2.1.3 Ramal e sub-ramais 243

6.2.2 Sistema Predial de suprimento de água quente $\quad 244$

6.2.3 Sistema Predial de suprimento de gás $\quad 245$

6.2.4 Sistema predial de prevenção e combate a incêndios $\quad 246$

$\begin{array}{ll}\text { 6.2.5 Sistema predial de coleta de esgoto sanitário } & 247\end{array}$

6.2.5.1 Tubos de queda e colunas de ventilação $\quad 247$ 
6.2.6 Sistema predial de coleta de águas pluviais

6.3 Metros de tubulação por número de pontos de consumo/captação e número de conexões por metro de tubulação

6.3.1 Sistema predial de suprimento de água fria

6.3.1.1 Ramal de distribuição

6.3.1.2 Ramais e sub-ramais

6.3.2 Sistema predial de suprimento de água quente

6.3.2.1 Ramal de distribuição

6.3.2.2 Ramal de retorno

6.3.2.3 Ramais e sub-ramais

6.3.3 Sistema predial de suprimento de gás

6.3.3.1 Ramal de distribuição

265

6.3.3.2 Ramais e sub-ramais

266

6.3.4 Sistema predial de coleta de esgoto sanitário - ramais

268

6.3.5 Sistema predial de coleta de águas pluviais - ramais

6.4 Estatísticas gerais

6.4.1 Metros de tubulação e número de conexões por área de apartamento-tipo

6.4.1.1 Sistema predial de suprimento de água fria

6.4.1.2 Sistema predial de suprimento de água quente

6.4.1.3 Sistema predial de suprimento de gás

6.4.1.4 Sistema predial de prevenção e combate a incêndios

278

6.4.1.5 Sistema predial de coleta de esgoto sanitário

6.4.1.6 Sistema predial de coleta de águas pluviais

6.4.2 Metros de tubulação por ponto de consumo/captação e número de conexões por metro de tubulação

6.4.2.1 Sistema predial de suprimento de água fria

6.4.2.2 Sistema predial de suprimento de água quente 


\section{VOLUME 2}

CAPÍTULO 7

7.1.1 Corte e rasgo de paredes

7.1.2 Produção de kits - cobre

7.1.3 Prumadas - cobre

7.1.4 Ramais de distribuição - cobre

7.1.5 Ramais/sub-ramais - paredes in loco e kits - cobre

7.1.6 Ramais/sub-ramais - sob a laje - cobre

7.1.7 Tubos de queda/colunas de ventilação esgoto/tubos de queda águas pluviais - PVC

7.1.8 Ramais de esgoto/águas pluviais - sob a laje - PVC

7.1.9 Ramais de esgoto - paredes

7.2.1 Fixação da tubulação nas paredes (argamassa)

7.2.2 Produção de kits - PVC e Cobre

7.2.3 Ramais de distribuição - PVC e Cobre

7.2.4 Ramais/sub-ramais - paredes in loco - PVC e Cobre e kits 300 $\mathrm{PVC} /$ Cobre

7.2.5 Ramais de esgoto/águas pluviais - sob a laje - PVC

7.2.6 Ramais de esgoto - paredes - PVC

7.3.1 Corte e rasgo de paredes

7.3.2 Produção de kits - Cobre

7.3.3 Prumadas - cobre 306

7.3.4 Ramais de distribuição: fixação e montagem - cobre 
7.3.6 Ramais/sub-ramais - paredes in loco - Cobre - Cozinha/AS; Ramais/sub-ramais - paredes in loco - Cobre - sanitários e Ramais/subramais - paredes kits - Cobre - sanitários

7.3.7 Tubos de queda/colunas de ventilação esgoto/tubos de queda -águas pluviais - PVC

7.3.8 Ramais de esgoto/águas pluviais - sob a laje - PVC

7.3.9 Ramais de esgoto - paredes - PVC - cozinha e área de serviço

7.4.1 Abertura e fixação de passantes

7.4.2 Abertura de shafts

7.4.3 Ramais de distribuição - PVC - Montagem

7.4.4 Ramais/sub-ramais água fria - sob a laje - PVC

7.4.5 Tubos de queda/colunas de ventilação esgoto/tubos de queda águas pluviais - PVC

7.4.6 Ramais de esgoto/águas pluviais - sob a laje - PVC

7.4.7 Ramais de gás - piso - Cobre

7.5 Considerações acerca dos resultados levantados

7.5.1 Distribuição dos Homens-hora

7.5.2 Resumo dos indicadores de produtividade da mão-de-obra (RUP)

\section{CAPÍTULO 8}

\section{PROGNÓSTICO DO CONSUMO DE MATERIAIS E PRODUTIVIDADE DA MÃO-DE-} OBRA

8.1 Fatores influenciadores do consumo unitário de materiais e da produtividade da mão-de-obra

8.1.1 Relacionados ao consumo unitário de materiais

8.1.2 Relacionados à produtividade da mão-de-obra

8.2 Prognóstico do consumo de materiais: Método Simplificado

\subsubsection{Apresentação}

8.2.2 Valores mínimo, mediano e máximo dos indicadores de consumo de metros de tubulação e número de conexões por área de apartamento-tipo 
8.2.2.4 Sistema predial de prevenção e combate a incêndios

8.2.2.5 Sistema predial de coleta de esgoto sanitário

8.2.2.6 Sistema predial de coleta de águas pluviais

8.3 Prognóstico do consumo de materiais: Método Analítico

8.3.2 Sistema predial de suprimento de água fria

8.3.2.1 Prumadas de água fria

8.3.2.2 Ramal de distribuição de água fria

8.3.2.3 Ramais e sub-ramais de água fria

8.3.3 Sistema predial de suprimento de água quente

8.3.3.1 Prumadas de água quente

8.3.3.2 Ramal de distribuição de água quente

8.3.2.3 Ramais e sub-ramais de água quente

8.3.4 Sistema predial de suprimento de gás

366

8.3.4.1 Prumadas de gás

8.3.4.2 Ramal de distribuição de gás 368

8.3.4.3 Ramais e sub-ramais de gás 368

8.3.5 Sistema predial de suprimento prevenção e combate a incêndios

8.3.6 Sistema predial de coleta de esgoto sanitário

8.3.6.1 Tubos de queda de esgoto sanitário

8.3.6.2 Colunas de ventilação e alça de ventilação

8.3.6.3 Ramais de esgoto sanitário

8.3.7 Sistema predial de coleta de água pluvial

8.3.7.1 Tubos de queda de águas pluviais

8.3.7.2 Ramais de águas pluviais 
8.4.3 Faixas de valores de RUP Potencial e de $\triangle R U P_{\text {Cumulativa - Potencial }} \quad \mathbf{3 8 8}$

8.5 Aplicação dos métodos de prognóstico 391

8.5.1 Características gerais do edifício $\quad 391$

8.5.2 Características dos sistemas prediais 393

8.5.3 Número de pontos de consumo e de captação por ambiente 395

8.5.4 Quantidade de tubos e conexões 396

8.5.5 Verificação dos métodos de prognósticos de consumo de materiais $\quad \mathbf{4 0 0}$

8.5.5.1 Prognóstico aplicando o método simplificado $\quad 400$

8.5.5.2 Prognóstico aplicando o método analítico $\quad 404$

8.5.6 Verificação do método de prognóstico da produtividade da mão-de- $\quad \mathbf{4 1 0}$ obra

8.5.6.1 Prognóstico aplicando o método analítico - SP1101

8.5.6.2 Prognóstico aplicando o TCPO (2003)

8.5.7 Análise da aplicação dos métodos $\quad 418$

$\begin{array}{ll}\text { CAPÍTULO } 9 & 421\end{array}$

9. CONSIDERAÇÕES FINAIS $\quad 421$

$\begin{array}{ll}\text { 9.1 Cumprimento dos objetivos } & \mathbf{4 2 3}\end{array}$

9.2 Verificação da hipótese básica $\quad 424$

$\begin{array}{ll}9.3 \text { Comparação da aplicabilidade dos métodos } & \mathbf{4 2 6}\end{array}$

$\begin{array}{ll}\text { 9.4 Estudo exploratório sobre perdas de tubos } & \mathbf{4 2 7}\end{array}$

$\begin{array}{ll}9.5 \text { Sugestões para estudos futuros } & \mathbf{4 3 0}\end{array}$

$\begin{array}{ll}\text { REFERÊNCIAS } & 433\end{array}$

BIBLIOGRAFIA COMPLEMENTAR $\quad 439$

$\begin{array}{ll}\text { APÊNDICES } & 447\end{array}$

APÊNDICE A - Exemplo de planilha "Fonte": montagem de ramais de esgoto $\mathbf{4 4 8}$ sanitário/ventilação sob o teto

APÊNDICE B - Exemplo de planilha de coleta de dados em obra: montagem de ramais $\quad \mathbf{4 5 0}$ de esgoto sanitário/ventilação sob o teto

APÊNDICE C - Planilhas de caracterização da edificação e dos sistemas prediais $\quad 456$

$\begin{array}{lll}\text { APÊNDICE D - } \quad \text { Quantitativos de projeto } & 477\end{array}$ 

prognósticos elaborados 


\section{CAPitulo 1}

\section{INTRODUÇÃO}

\subsection{A importância da melhoria da produtividade no uso dos recursos físicos nos canteiros de obras}

A preocupação com a melhoria da produtividade e qualidade, principalmente na área industrial, tem sido uma constante nos países desenvolvidos e vem se intensificando nos países em processo de desenvolvimento.

Tal situação advém do fato de que países e empresas têm adquirido cada vez mais a consciência de que a melhoria na produtividade constitui-se em eficiente atalho para o progresso e crescimento econômico, uma vez que maior produtividade significa um melhor aproveitamento de recursos na produção de bens ou serviços necessários à comunidade (MOREIRA, 1991).

Para Maruoka; Souza (1999) a produtividade está intrinsecamente relacionada ao lucro, uma vez que empresas com melhores índices de produtividade terão menores custos de produção, podendo, assim, oferecer produtos a preços mais competitivos ou trabalhar com maior margem de lucro.

Reforçando a estreita relação entre a competitividade e a produtividade, Marques (1995) complementa que a competência constitui-se no fim pretendido pelas empresas, enquanto que um dos meios para atingi-la consiste na melhoria da produtividade. 
No âmbito da Indústria da Construção Civil, podem-se enumerar vários fatores indutores da necessidade da melhoria da produtividade, dentre os quais se ressalta o atual cenário de competição, acentuado na década de 90 , e motivado por ações ocorridas nos últimos anos, tais como: a abertura do mercado nacional ao capital estrangeiro, a implantação do Código de Defesa do Consumidor entre outros (PICCHI, 1993).

De acordo com Cardoso (1996), o Código de Defesa do Consumidor forneceu meios legais aos consumidores para reivindicar seus direitos, garantindo-lhes seu poder de negociação e, conseqüentemente, a possibilidade de exigir qualidade dos produtos ofertados assim como o respeito ao prazo de execução das obras. Assim, o mercado consumidor tornou-se mais exigente em relação aos bens que está adquirindo, contribuindo para o aumento da competição entre as empresas construtoras e incorporadoras.

Por outro lado, a participação no Mercosul e a diminuição de barreiras à entrada de vários produtos importados no mercado interno também contribuíram para o aumento da competição entre as empresas, fazendo com que as mesmas, neste novo cenário, busquem incessantemente a melhoria da produtividade dos seus processos e qualidade dos seus produtos (BORNIA, 1995).

Embora se reconheçam as vantagens da melhoria da produtividade no uso dos recursos físicos e, conseqüentemente, dos recursos financeiros, a produtividade de alguns segmentos da cadeia produtiva do Brasil está aquém do nível que pode alcançar quando comparada com a produtividade dos mesmos segmentos da cadeia produtiva de países desenvolvidos.

De acordo com o estudo realizado pelo Mckinsey Global Institute, em se tratando da Indústria da Construção Civil no Brasil, mais especificamente no que diz respeito à mão-de-obra, a sua produtividade é de apenas $32 \%$ quando comparada à Indústria de 
Construção Civil dos Estados Unidos, sendo que, no subsetor de edificações, esta porcentagem atinge 35\% (McKINSEY GLOBAL INSTITUTE, 1998).

No que diz respeito aos materiais e componentes, não é comum utilizar o termo produtividade para expressar a eficiência na transformação dos materiais em produtos de construção civil, e sim o termo consumo unitário, que expressa a quantidade de material utilizada por unidade de serviço executado ( $\mathrm{kg}$ de aço por $\mathrm{m}^{3}$ de estrutura) ou por área de construção $\left(\mathrm{m}^{3}\right.$ de concreto por $\mathrm{m}^{2}$ de pavimento-tipo).

Por sua vez, o consumo unitário pode ser dividido em duas parcelas: a relativa ao projeto, que expressa o consumo de material de acordo com sua concepção e especificação; e a relativa ao canteiro de obras, que expressa a quantidade excedente de material utilizada na execução dos serviços, quantidade esta denominada perda.

Assim, melhorar a eficiência (ou reduzir a ineficiência) no uso dos materiais implica em ações adotadas tanto no âmbito da etapa de projeto quanto na etapa de execução, ou seja, no canteiro de obras.

No que diz respeito ao canteiro de obras, em uma pesquisa nacional realizada na segunda metade da década de 90 sobre perdas de materiais, envolvendo quase uma centena de canteiros de obras, esta ineficiência, traduzida nos valores de perdas detectados, representou de 3 a $8 \%$ do custo total da obra e $20 \%$ da massa prevista para o edifício (SOUZA et al. , 2000) ${ }^{1}$.

\footnotetext{
1 Trata-se da pesquisa financiada pela FINEP - Financiadora de Estudos e Projetos do Ministério da Ciência e Tecnologia, intitulada "Alternativas para a redução do desperdício de materiais nos canteiros de obras", envolvendo pesquisadores de mais 16 universidades nacionais, sob a coordenação do Departamento de Engenharia de Construção Civil da EPUSP, cujos objetivos principais foram: levantar índices de perdas de materiais/componentes nos canteiros de obras, identificar suas causas e, com base nos resultados obtidos, subsidiar alternativas para a redução das mesmas.
} 
Além do aspecto financeiro envolvido, as implicações de tal ocorrência extrapolam o âmbito dos canteiros de obras, pois ao se desperdiçarem materiais e componentes, estar-se-á incorrendo em desperdício de recursos naturais, prejudicando toda a sociedade (PALIARI, 1999).

Assim, sob o ponto de vista ambiental, a redução das perdas de materiais traz como benefício a redução do consumo desses recursos naturais, além da redução do entulho gerado, cujas áreas para sua deposição estão se exaurindo, principalmente nos grandes centros urbanos. Este fato é extremamente desejável uma vez que, segundo Sjöström $(1996)^{2}$ citado por John (2000), 14\% a 50\% de todos os recursos extraídos da natureza são destinados à indústria da construção civil.

Quanto a este último aspecto, Andrade et al. (2001a), utilizando os valores medianos de perdas de materiais obtidos na pesquisa nacional anteriormente citada, chegaram ao valor de $49,6 \mathrm{~kg} / \mathrm{m}^{2}$ de entulho gerado por unidade de área construída, representando aproximadamente $5 \%$ da massa do edifício ${ }^{3}$.

Por todos estes aspectos, evidencia-se a deficiência existente nos processos produtivos na indústria da construção civil nacional quanto ao uso dos recursos físicos; por outro lado, detecta-se a existência de um grande potencial para a melhoria da sua produtividade com base em métodos adequados de prognóstico e controle.

Esta melhoria pode ser alcançada através da elaboração de políticas voltadas para o aumento da produtividade, sejam elas no âmbito de toda a cadeia produtiva ou apenas no âmbito do canteiro de obras, envolvendo tanto aspectos gerenciais quanto tecnológicos.

\footnotetext{
${ }^{2}$ SJÖSTRÖM, C. Service life of the building. In: Applications of the performance concept in building. Proceedings... CIB: Tel Aviv, 1996 v.2, p.6-11.

${ }^{3}$ Para calcular este percentual, os autores consideraram a massa total do edifício igual a $1.000 \mathrm{~kg} / \mathrm{m}^{2}$.
} 
Devido à necessidade de se ter mais eficiência na administração dos recursos físicos, vários programas direcionados para a melhoria da qualidade e produtividade foram articulados entre o setor produtivo, entidades governamentais e patronais, sindicatos e universidades. Podem ser citados, por exemplo, o Programa da Qualidade e da Produtividade na Construção Civil do Rio Grande do Sul e Sistema de Gestão para Empresas Construtoras do SINDUSCON de São Paulo. Em 1996 foi lançado o QUALIHAB (Programa da Qualidade da Construção Habitacional do Estado de São Paulo ${ }^{4}$ ) e, em novembro de 1997, foi lançado o Programa Brasileiro da Qualidade e Produtividade do Habitat - PBQP-H - que conta, entre outras instituições, com a participação direta do Departamento de Engenharia de Construção Civil da Escola Politécnica da Universidade de São Paulo - PCC-EPUSP.

As diretrizes destes programas indicam que as empresas construtoras devem gerenciar melhor seu sistema produtivo, a qualidade dos seus produtos e serviços, assim como a de seus fornecedores.

No entanto, um maior sucesso destas ações depende, em grande parte, do conhecimento do atual desempenho praticado pela empresa e, neste sentido, em se tratando da melhoria da produtividade no uso dos recursos físicos nos canteiros de obras, há a necessidade de métodos de coleta e análise de informações que subsidiem propostas consistentes para esta melhoria desejada, através de dados confiáveis, representativos e que levem em consideração o atual patamar de desenvolvimento tecnológico e gerencial existente nas empresas (PALIARI, 1999).

\footnotetext{
${ }^{4}$ O QUALIHAB tem como objetivo a certificação da qualidade dos materiais e componentes e empresas construtoras e fornecedoras de serviços e produtos para a participação dos processos de licitação da CDHU (Companhia de Desenvolvimento Habitacional e Urbano do Estado de São Paulo).
} 
Segundo este autor, insere-se ainda a necessidade de um método que permita realizar o prognóstico da produtividade da mão-de-obra e do consumo unitário de materiais de uma forma sistêmica, considerando os fatores que interferem na produtividade da mão-de-obra e/ou no consumo de materiais.

Trabalhos neste sentido vêm sendo desenvolvidos recentemente, destacando-se, em se tratando de materiais e componentes, os realizados por Paliari (1999) e Andrade $(1999)^{5}$. Em se tratando da mão-de-obra, destacam-se os trabalhos realizados por Souza (1996), Carraro (1998), Araújo (2000) e Librais (2001), todos eles desenvolvidos no âmbito do Programa de Pós-Graduação do Departamento de Engenharia Civil da Escola Politécnica da Universidade de São Paulo.

Tais pesquisas procuraram avaliar, de forma sistemática, os valores das perdas de materiais e componentes e a produtividade da mão-de-obra, colocando atenção não apenas em sua medição, mas também nos aspectos relacionados ao controle e ao prognóstico destes recursos, levando em consideração a especificidade dos serviços avaliados e sua complexidade.

Embora se percebam avanços significativos em tais pesquisas, as mesmas foram focadas em serviços relacionados à execução de estrutura, vedação e revestimentos internos.

No que diz respeito a trabalhos internacionais, verifica-se também o foco nos serviços de estrutura, vedação e acabamentos. Como exemplo, cita-se o trabalho desenvolvido por Enshassi et. al (2007) para a avaliação da produtividade da mão-de-obra na

\footnotetext{
${ }^{5}$ Estas pesquisas tratam da questão das perdas de materiais e componentes nos canteiros de obras e não especificamente da produtividade. No entanto, fica clara a relação entre estes dois conceitos à medida que, ao se produzir com menores perdas, estar-se-á melhorando a produtividade.
} 
execução da alvenaria de vedação, utilizando os mesmos conceitos dos trabalhos nacionais citados anteriormente.

Quanto aos sistemas prediais, foram identificados dois trabalhos semelhantes nacionais sobre produtividade da mão-de-obra na execução de redes coletoras de esgotos sanitários, realizados e publicados por Sautchúk et al. (2001) e Rezende Neto et al. (2002), que, embora tratem de sistemas prediais, não abrangem os sistemas prediais hidráulicos no âmbito do edifício. Além destes, pode-se citar outro trabalho, com participação deste autor, ainda que pouco aprofundado, sobre a avaliação da produtividade na execução dos sistemas prediais hidráulicos e sanitários realizado em uma obra localizada na cidade de São Paulo, cujo detalhamento pode ser visto em Paliari et. al (2003).

No âmbito internacional, identificou-se um trabalho realizado por Han; Thomas (2003) no âmbito do 11th Joint CIB International Symposium, realizado em Singapura, a respeito do levantamento da perda da produtividade da mão-de-obra na execução de dutos de ar condicionado em um edifício do State College, Pennsylvania - USA.

Há, portanto, uma carência de informações sobre a produtividade da mão-de-obra e consumo unitário nestes serviços que permitam aos seus gestores realizar um planejamento e programação de forma mais eficiente, dimensionar suas equipes de trabalho e definir tarefas com maior precisão.

\subsection{A importância do estudo da produtividade da mão-de-obra e do consumo unitário de materiais nos sistemas prediais hidráulicos}

Os sistemas prediais podem ser definidos como "sistemas físicos integrados a um edifício e que têm por finalidade dar suporte às atividades dos usuários, suprindo-os com insumos prediais necessários e propiciando os serviços requeridos" (GONÇALVES, 1994). 
Segundo Peixoto (2000), ao se considerar sua finalidade, os sistemas prediais podem ser divididos em: energia elétrica, gás combustível, comunicações (telefonia e interfonia), transporte mecanizado (elevadores e escadas rolantes), segurança e proteção contra incêndio, automação predial, suprimento, coleta e disposição de água (água fria, água quente, esgoto e águas pluviais) entre outros.

A sua importância reside não só no fato de proporcionar condições de higiene e conforto aos usuários, mas também, pelo seu alto grau de interferência com os demais sistemas, abrangendo desde a etapa de estrutura até a etapa de acabamento final do edifício, exigindo a prestação de serviços de operários especializados na obra (GONÇALVES, 1994).

Em termos de custos, a análise da Tabela de Estimativas de Custos por Etapa da Obra (CONSTRUÇÃO MERCADO, 2005) permite concluir que os sistemas prediais hidráulicos e sanitários podem representar de $5 \%$ a $14 \%{ }^{6}$ do custo total da obra, dependendo do tipo de construção.

Além desta representatividade, pelo fato de praticamente estarem relacionados a vários subsistemas de uma edificação, atrasos na sua execução implicam em custos adicionais consideráveis, justificando assim a necessidade de um maior controle na sua execução e, para isto, a utilização de indicadores de produtividade da mão-deobra mais realistas servem a este propósito.

Soma-se a isto o fato de ser muito comum a falta de planejamento da execução destes sistemas, seja pela ausência de indicadores de produtividade da mão-de-obra mais confiáveis, seja pelo desinteresse do construtor em controlar de forma mais eficiente sua execução, repassando tal responsabilidade a terceiros que, muitas vezes, não dispõem de ferramentas gerenciais adequadas a este propósito.

\footnotetext{
${ }^{6} \mathrm{O}$ índice de $5 \%$ refere-se a um galpão industrial de porte médio $\left(1.550 \mathrm{~m}^{2}\right)$ enquanto que o índice de $14 \%$ diz respeito a um edifício residencial de 29 pavimentos $\left(18.900 \mathrm{~m}^{2}\right)$.
} 
Em pesquisa realizada por Serra (2001) em 15 empresas do estado de São Paulo, 13 empresas, ou seja, $86,7 \%$ das consultadas, terceirizavam a execução dos sistemas prediais hidráulicos e sanitários, sendo que 8 delas terceirizam somente a mão-deobra e 5 empresas tanto a mão-de-obra quanto os materiais empregados.

Esta situação de menor controle por parte do contratante resulta, muitas vezes, em elevada incidência de problemas patológicos. A este respeito, Amorim (1997), analisando os gastos com manutenção dos Sistemas Hidráulicos Prediais em 6 edifícios localizados na cidade de São Paulo, aponta que os valores representam aproximadamente $1,28 \%$ do custo total da obra.

Segundo Peixoto (2000), os estudos realizados nesta área são direcionados ao desenvolvimento de métodos alternativos de dimensionamento, ao estudo dos fenômenos hidráulicos que ocorrem nas tubulações e normalização dos sistemas prediais, havendo, portanto, poucos estudos significativos relacionados à racionalização destes sistemas. Destaca, entretanto, o realizado por Amorim (1997), que foca a estruturação de um sistema de informações para o desenvolvimento de projetos dos sistemas hidráulicos prediais, e Ilha (1993), que aborda a qualidade nas etapas de projeto e execução destes sistemas.

Ilha et. al (2006), tendo-se como base os anais de seis eventos do Encontro Nacional de Tecnologia no Ambiente Construído (ENTAC), importante evento na área de qualidade e produtividade, além de outros assuntos relacionados ao ambiente construído, evidenciaram um número crescente de artigos técnicos relacionados aos sistemas prediais.

No entanto, segundo o levantamento destes autores, a maioria dos artigos estava relacionada aos temas de conservação e economia de água, gestão da qualidade dos sistemas prediais e inovações tecnológicas nestes sistemas, correspondendo a $89 \%$ dos trabalhos publicados nas seis oportunidades em que este evento fora realizado. 
Os $11 \%$ restantes se relacionavam à conservação/economia de energia no aquecimento de água e outros temas, evidenciando a carência de trabalhos semelhantes ao proposto neste trabalho acerca destes sistemas.

Sob o ponto de vista do consumo de materiais, os primeiros números nacionais a respeito dos sistemas prediais foram obtidos em pesquisa financiada pela FINEP. Num conjunto de 7 obras pesquisadas, os indicadores de perdas variaram de $8 \%$ a $56 \%$ (AGOPYAN et al., 1998). Dentre os materiais avaliados nesta pesquisa, os relacionados aos sistemas prediais foram os que tiveram seus estudos menos aprofundados devido à dificuldade de se levantar indicadores parciais que pudessem explicar a grande parcela de perdas detectada e proporcionar formas eficazes de combatê-las levando-se em consideração a relação custo/benefício.

Assim, em que pese a importância que tais sistemas assumem na edificação, verificase a escassez de números acerca do consumo de materiais relacionados a estes sistemas, sobretudo da produtividade da mão-de-obra.

Esta situação se agrava mais ainda na medida em que vem se intensificando, no setor, a inserção de novas tecnologias como os sistemas hidráulicos flexíveis, cuja distribuição de água pode ser feita ponto a ponto, com tubulações contínuas desde um registro até os pontos de abastecimento, com tubulações independentes para cada atividade, ou pelo método tradicional, através da utilização de "tês" para a distribuição da água (TECHNE, 2000).

No que diz respeito ao consumo unitário teórico, o estabelecimento de um modelo de prognóstico, que permita sua estimativa com base em fatores de concepção dos sistemas prediais e de arquitetura, poderá subsidiar a escolha da concepção destes sistemas ainda na fase do estudo da viabilidade do empreendimento. 
Por todos estes aspectos, justifica-se a realização de um estudo sobre a produtividade da mão-de-obra, consumo unitário e perdas de materiais envolvidos na execução dos sistemas prediais, contemplando um método para seu prognóstico.

\subsection{A necessidade de um método para o prognóstico da produtividade da mão- de-obra e do consumo unitário de materiais nos sistemas prediais hidráulicos}

A busca pelo correto prognóstico do consumo de recursos na construção civil permite às empresas construtoras adquirirem uma vantagem competitiva na negociação com fornecedores de mão-de-obra e materiais, assim como maiores probabilidades de sucesso na participação de licitações públicas e privadas.

De acordo com Proverbs; Olomaye (1999), o conhecimento da produtividade constituise numa parte essencial no processo de planejamento e gerenciamento da construção, no processo de orçamento e controle dos custos de produção.

Além do mais, serve para promover também a discussão no âmbito da etapa de projeto, visando uma concepção e especificação que levem em consideração também os aspectos de execução e não somente os de dimensionamento.

No campo do planejamento operacional e programação dos serviços de construção civil, a capacidade de a empresa prognosticar, com maior precisão, a produtividade da mão-de-obra e o consumo unitário de materiais, reverte-se em economia na medida em que poderá ser programada corretamente a compra dos materiais, assim como, a contratação de serviços e/ou mão de obra para execução.

Em que pese estas vantagens, para Andrade et al. (2001b), os processos de orçamento utilizados pela Indústria da Construção Civil são compostos por índices de consumo unitário de materiais e produtividade da mão-de-obra de origem muitas 
vezes desconhecida, sendo os valores em muitas ocasiões contestados pelos usuários.

Segundo ainda estes autores, a falta de índices que representem a realidade da empresa a leva a adotar índices médios do setor, que podem diferir da realidade presente em seus canteiros de obras, acarretando em um processo de prognóstico falho.

Corroborando com tal afirmação, para Souza (2001), a "busca de informações prévias que permitam o entendimento do consumo dos recursos depende hoje de fontes que não têm sido tão eficazes em transmitir conhecimentos adequados para a redução do consumo indevido de materiais e de mão-de-obra".

Para este autor, o caminho tradicional para tal busca, tanto no Brasil quanto em outros países, consiste na consulta de manuais de orçamentação. Alternativamente, inserese a utilização de bancos de dados próprios das empresas construtoras ou informações levantadas por Instituições de Pesquisas.

A utilização de um banco de dados da própria empresa configura-se na alternativa que mais representa seu desempenho, uma vez que reflete as experiências vivenciadas pela mesma no mercado de construção. No entanto, é comum deparar-se com situações onde tais números são extraídos sem uma metodologia específica quanto às características inerentes aos serviços envolvidos, além do fato de a informação obtida representar o desempenho global, não permitindo identificar quais os pontos a serem melhorados.

Com relação à utilização de informações levantadas por Instituições de Pesquisa, Souza (2001) resume que as experiências vivenciadas são em quantidade e abrangência limitadas e a divulgação dos resultados obtidos é restrita. Da mesma forma, ressalta a existência de problemas quanto à nomenclatura e procedimentos 
uniformizados para se levantarem indicadores de consumo unitário de materiais e de produtividade da mão-de-obra que permitam a comparação de resultados.

No que diz respeito aos manuais de orçamentação, verifica-se a utilização corrente do TCPO - Tabelas de Composições de Preço para Orçamento, ou de outros manuais derivados destas tabelas.

Embora o TCPO (2000) tenha passado por uma reformulação, introduzindo o conceito de produtividade variável ${ }^{7}$, o mesmo não se aplica aos sistemas prediais, exatamente pela escassez de pesquisas que consolidem esta prática. Assim, persiste uma incoerência na medida em que os valores de produtividade da mão-de-obra são atribuídos em função do diâmetro e material da tubulação, quando, na realidade, deveriam ser associados às partes inerentes à execução dos sistemas, tais como prumadas, ramais e sub-ramais, cada qual com suas especificidades de execução.

Acrescenta-se ainda o fato de não se preverem também opções de organização de produção, como, por exemplo, a confecção de kits em centrais de produção, assim como a forma de contratação dos profissionais envolvidos na execução destes sistemas.

No campo do consumo de materiais, o Núcleo Orientado para a Inovação da Edificação (NORIE) da Universidade Federal do Rio Grande do Sul (UFRGS)desenvolveu o Sistema de Indicadores de Qualidade e Produtividade para a Construção Civil, com o objetivo de orientar as empresas na coleta de indicadores, assim como no estabelecimento de valores de referência setorial que permitam às mesmas comparar o seu desempenho com outras empresas do setor e estabelecer metas para melhoria contínua.

\footnotetext{
${ }^{7}$ O TCPO (2003) traz faixas de valores de consumo unitário de materiais e de produtividade da mão-de-obra para determinados serviços, ao contrário da edição de 2000.
} 
Neste Sistema desenvolvido, mais especificamente no item relacionado ao gerenciamento de projetos, apresenta-se um indicador de qualidade do projeto de sistemas prediais e de arquitetura denominado índice de tubulações hidráulicas, que relaciona o comprimento das tubulações de água fria e água quente com o número de pontos hidráulicos. De acordo com o banco de dados, disponível até o momento, os valores médios para este indicador são de 3,2 metros/ponto para os imóveis residenciais e de 3,3 metros/ponto para os imóveis comerciais, com respectivos valores mínimos de 1,2 metros/pontos e 2,4 metros/pontos ${ }^{8}$.

Em que pese a importância desta informação, a mesma ainda carece de um melhor detalhamento para os propósitos de prognóstico proposto neste trabalho. Desta forma, acredita-se ser possível contribuir significativamente no que diz respeito à melhoria da previsão do consumo destes recursos, gerando subsídios para a melhoria do processo de previsão e planejamento e programação dos serviços relacionados aos sistemas prediais hidráulicos e, conseqüentemente, da contratação e gerenciamento dos operários e subempreiteiros.

\subsection{Contexto do trabalho}

A preocupação com o uso racional dos recursos físicos na construção civil vem se intensificando nos últimos anos no meio técnico e acadêmico. Procurando contribuir com a discussão a respeito da gestão destes recursos nos canteiros de obras, o Departamento de Engenharia de Construção Civil da Escola Politécnica da Universidade de São Paulo (PCC-EPUSP) vem desenvolvendo um conjunto de trabalhos de pós-graduação nesta direção, envolvendo várias instituições, como a FINEP - Financiadora de Estudos e Projetos do Ministério da Ciência e Tecnologia,

\footnotetext{
${ }^{8}$ Este Sistema de Indicadores está disponível no seguinte endereço eletrônico:

http://www.cpgec.ufrgs.br/norie/indicadores/topo.htm. Os valores apresentados são relativos a dezembro de 2007.
} 
diversas universidades distribuídas pelo país, além de várias empresas construtoras localizadas no Estado de São Paulo.

Este trabalho vem somar-se aos outros já desenvolvidos no âmbito do Grupo de Ensino e Pesquisa em Tecnologia e Gestão da Produção de Edifícios (GEPE-TGP), mais especificamente na linha de pesquisa denominada Gestão da Produção na Construção Civil, cuja ênfase em Produtividade e Perdas na Construção Civil, sob coordenação do Prof. Dr. Ubiraci Espinelli Lemes de Souza, visa o desenvolvimento de metodologias e ferramentas para avaliação e incremento da produtividade dos processos e métodos construtivos, como também ao estudo das principais fontes de perdas e ao desenvolvimento de ferramentas para a intervenção em obras.

\subsection{Metodologia da pesquisa}

O conceito de metodologia de pesquisa está contido nas suas palavras. A palavra metodologia é uma combinação de duas outras derivadas do grego - Método (methodo) e logia (logos). A primeira significa organização; sistematização enquanto que a segunda significa estudo sistemático (BARBOSA FILHO, 1980).

Por sua vez, a palavra pesquisa significa procura, investigação ou a busca pelo desconhecido. Portanto, segundo este autor, metodologia de pesquisa significa o estudo ou investigação sistemática, ou seja, um meio racional de se obter o conhecimento.

Para Leopardi (2002), metodologia "é a arte de dirigir o espírito na investigação da verdade, por meio do estudo dos métodos, técnicas e procedimentos capazes de possibilitar o alcance dos objetivos", sendo variável de acordo com o problema a ser investigado. 
Assim, para esta autora, a metodologia deve incluir "o que fazer" (procedimentos gerais de estudo ou o método), o "como" desenvolver a pesquisa, envolvendo as técnicas para coleta de dados, assim como as informações que se pretende obter com a aplicação destas técnicas e os instrumentos de coleta utilizados para tal. Mais do que isto, deve apresentar também os meios para processamento dos dados e a forma de análise dos mesmos para a obtenção da resposta ao problema formulado.

\subsubsection{Pesquisa científica}

O conhecimento científico ${ }^{9}$ é caracterizado por ser um conhecimento contingente, na medida em que suas proposições e hipóteses têm sua veracidade ou falsidade conhecida através de experimentação, e não apenas da razão. É sistemático, uma vez que se trata de um saber ordenado logicamente e possui a característica da verificabilidade, na medida em que as afirmações (hipóteses) não comprovadas não pertencem ao âmbito da ciência verificável. Da mesma forma, é falível, na medida em que não é definitivo, absoluto ou final e, finalmente, por este último motivo, é aproximadamente exato, na medida em que o desenvolvimento de novas técnicas pode reformular o acerto de teoria existente (MARCONI; LAKATOS, 1991).

É neste contexto que se insere a pesquisa científica, que pode ser definida como o procedimento racional e sistemático que tem como objetivo proporcionar respostas aos problemas, ou seja, é requerida quando não se dispõe de informações suficientes para responder ao problema, ou, então, quando as informações disponíveis

\footnotetext{
9 Metodologicamente, o conhecimento pode ser dividido em 4 categorias: conhecimento popular, conhecimento filosófico, conhecimento religioso e, finalmente, o conhecimento científico (MARCONI; LAKATOS, 1991). Embora se reconheça a contribuição dos outros conhecimentos para o avanço da ciência e, muitas vezes os mesmos coexistam em determinadas situações, é através do conhecimento científico que a Humanidade tem conseguido sucessos consideráveis.
} 
se encontram desordenadas, não podendo ser adequadamente relacionadas ao problema (GIL, 1991).

De uma forma mais analítica, os objetivos a serem atingidos por uma pesquisa científica são a demonstração da existência (ou ausência) de relações entre diferentes fenômenos; o estabelecimento da consistência interna entre conceitos dentro de uma dada teoria; o desenvolvimento de novas tecnologias ou demonstração de novas aplicações de tecnologias conhecidas; o aumento da generalidade do conhecimento; e, finalmente, a descrição das condições sob as quais um fenômeno ocorre (LUNA, 2002).

O caminho entre um problema formulado ou uma questão a ser investigada dentro de uma pesquisa científica é delineado através do Método Científico.

\subsubsection{Método científico}

Em seu sentido mais geral, um método consiste na ordem que se deve impor aos diferentes processos necessários para atingir um fim ou um resultado desejado, ou seja, um conjunto ordenado de procedimentos que se mostraram eficientes, ao longo da História, na busca do saber (CERVO; BERVIAN, 1996).

De acordo com Leopardi (2002), o método científico caracteriza-se como um conjunto de operações empíricas ou lógicas desenvolvidas pelo pesquisador na busca da comprovação da tese ou de hipóteses sobre fatos, representações ou fenômenos.

Em outras palavras, trata-se do caminho pelo qual os pesquisadores produzem o conhecimento científico, caminho este que não é único uma vez que está ligado diretamente ao tipo de pesquisa que se deseja desenvolver. 
Segundo a autora, o método científico apresenta, em geral, quatro momentos distintos e inter-relacionados: formulação do problema de pesquisa, delineamento da pesquisa (classificação), coleta de dados e análise de dados e, desta forma, a chegada a conclusões plausíveis.

Do Método Científico deriva-se o Método de Pesquisa que, por sua vez, está ligado diretamente ao tipo de pesquisa que se deseja realizar (ou seja, a resposta que se deseja) e, como conseqüência, terá etapas distintas no que diz respeito a sua natureza e quantidade.

Reunindo estes conceitos, na Figura 1.1 apresenta-se um fluxograma envolvendo a Metodologia de Pesquisa, Método Científico e Método de Pesquisa

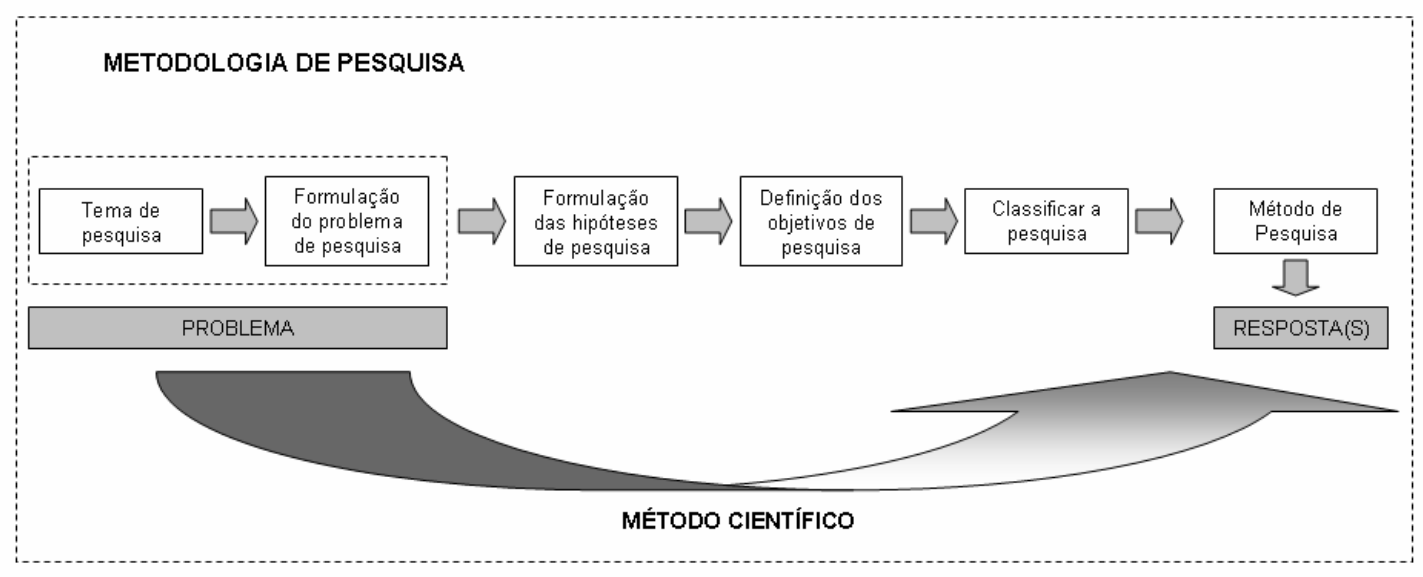

Figura 1.1 - Etapas da Metodologia de Pesquisa 


\subsubsection{Tema e formulação do problema de pesquisa}

\subsubsection{Tema de pesquisa}

Todo tipo de pesquisa se inicia com algum tipo de problema, seja de ordem prática ou de ordem intelectual a ser resolvido, cabendo ressaltar que nem todo o problema formulado é passível de tratamento científico (GIL, 1991).

No entanto, antes da formulação do problema de pesquisa é necessário identificar o tema de pesquisa no qual o mesmo está inserido, para, em seguida, recortar o tema de pesquisa em termos de um problema específico.

Neste sentido, o tema de uma pesquisa é o assunto que se deseja provar ou desenvolver, de caráter abrangente, enquanto que o problema assume um caráter mais específico, indicando exatamente qual a dificuldade que se pretende resolver (LAKATOS; MARCONI, 1991).

A escolha do assunto ou tema costuma ser previamente determinada institucionalmente, a partir de linhas de pesquisa e contratos de pesquisa ou parte da decisão pessoal do pesquisador, ou de uma dificuldade prática enfrentada, da sua curiosidade científica, dos desafios encontrados em alguns assuntos ou teorias (LEOPARDI, 2002).

Além de verificar o próprio interesse sobre o assunto da pesquisa e das condições para sua execução, o tema de pesquisa deve ser delimitado e, para isto, algumas regras podem se seguidas. A primeira regra consiste em distinguir o sujeito e o objeto da questão (MARCONI; LAKATOS, 2001).

Segundo estes autores, o sujeito pode ser entendido como sendo a realidade sobre a qual se deseja saber alguma coisa e pode ser constituído por objetos, fatos, 
fenômenos ou pessoas (deseja-se melhor aprendê-los ou tem-se a intenção de agir sobre eles), enquanto que o objeto é tema propriamente dito; ou seja, corresponde àquilo que se deseja saber ou realizar a respeito do sujeito.

Seguindo estas definições e nomenclaturas, podem-se distinguir, para a presente tese, dois sujeitos e dois objetos de pesquisa:

Produtividade da mão-de-obra e consumo unitário de materiais na Indústria da Construção Civil.

Evidentemente, tais temas encontram-se abrangentes e precisam ser delimitados. Para esta delimitação, utilizam-se alguns limites de extensão do tema, tanto do sujeito quanto do objeto (MARCONI; LAKATOS, 2001). Segundo estes autores, para a delimitação do tema podem ser utilizados adjetivos explicativos ou restritivos na formulação do tema, complemento nominal de especificação e determinação de circunstâncias de tempo e espaço.

Assim, apresenta-se para a presente tese o seguinte tema de pesquisa delimitado:

Produtividade da mão-de-obra e consumo unitário de materiais na execução de sistemas prediais hidráulicos de obras residenciais de múltiplos pavimentos, com foco no pavimento-tipo.

\subsubsection{Problema de pesquisa}

A pesquisa deve ser fundamentada e metodologicamente construída objetivando a resolução ou esclarecimento de um problema, que consiste, portanto, no ponto de partida da pesquisa (SILVA; MENEZES, 2001). 
O problema, portanto, consiste "em um enunciado explicitado de forma clara, compreensível e operacional, cujo melhor modo de solução ou é uma pesquisa ou pode ser resolvido por meio de processos científicos já existentes" (LAKATOS; MARCONI, 1991).

A clareza da formulação do problema também é destacada por Luna (2002), uma vez que tornará mais fácil e adequado o processo de decisões posteriores. No entanto, o autor enfatiza que essa clareza não significa que o pesquisador, ao longo da sua pesquisa, não precise reformular o problema, uma vez que o processo de pesquisa é essencialmente dinâmico.

Assim, formular um problema científico não é uma tarefa fácil e depende muito da experiência do pesquisador sobre determinado assunto (GIL, 1991). Além do mais, outros fatores devem ser considerados na sua escolha, tais como sua originalidade e relevância e as possibilidades reais de realização da pesquisa (recursos financeiros, tempo e motivação pessoal para a realização da pesquisa) (MARCONI; LAKATOS, 2001).

No que diz respeito especificamente à formulação do problema, Gil (1991) apresenta alguns requisitos ou regras que devem ser seguidos:

- deve ser formulado como pergunta: na medida que se constitui a forma mais fácil e direta de se formulá-lo;

- dever ser claro e preciso: sob pena de não se conseguir solucioná-lo;

- deve ser empírico: na medida em que não deve se referir a valores e, quando se referir, deve se referir a fatos empíricos e não a percepções pessoais;

- deve ser suscetível de solução: ser possível coletar dados para a solução; 
- deve ser delimitado a uma dimensão viável: não ser formulado em termos muito amplos.

Com base no exposto, formula-se o presente problema de pesquisa:

Para os sistemas prediais hidráulicos, é possível elaborar métodos de prognóstico, tanto para a produtividade da mão-de-obra quanto para o consumo unitário de materiais levando-se em consideração seus fatores potencialmente influenciadores?

\subsubsection{Hipótese}

Uma vez formulado o problema de pesquisa, com a certeza de ser cientificamente válido, o passo seguinte consiste em se propor uma resposta "suposta, provável e provisória" para o mesmo, ou seja, uma hipótese (LAKATOS; MARCONI, 1991).

Segundo Pádua (1996), etimologicamente, a palavra hipótese significa o que está e surge com a formulação do problema levantado pelo pesquisador, que poderá ou não ser confirmada pela pesquisa.

Para Lakatos; Marconi (1991), ambos (problema e hipótese) são enunciados de relações entre variáveis (fatos, fenômenos); no entanto, diferem no fato de que o problema constitui uma sentença interrogativa, enquanto que e a hipótese constitui uma sentença afirmativa.

Leopardi (2002) afirma que a função da hipótese é "fixar a diretriz da pesquisa, tanto no sentido prático, orientado pela coleta de dados, quanto no sentido teórico, coordenando os resultados em relação a um sistema explicativo ou teoria". 
Silva; Menezes (2001) indicam também que, para um mesmo problema, poderá haver várias hipóteses, ou seja, possíveis soluções para a resolução do problema formulado, e esta(s) irá(ão) orientar o planejamento dos procedimentos metodológicos necessários à execução da pesquisa que irão comprová-la(s), sustentá-la(s) ou, até mesmo, refutá-la(s).

Diante do exposto, formula-se a seguinte hipótese básica:

Os indicadores de produtividade da mão-de-obra e consumo unitário de materiais variam com a presença ou não de alguns fatores, que podem ser identificados e cuja influência pode ser quantificada.

Resultando na seguinte tese:

É possível desenvolver um método de prognóstico do consumo unitário de materiais $^{10}$ simplificado aplicável à etapa de viabilidade do empreendimento e outro, de forma analítica, aplicável à etapa de anteprojeto ou projeto de arquitetura com base em fatores influenciadores deste consumo.

O mesmo se aplica à produtividade da mão-de-obra, com a elaboração de um método de prognóstico levando-se em consideração seus fatores influenciadores nas várias etapas construtivas inerentes à execução dos sistemas prediais hidráulicos.

\footnotetext{
10 Embora se utilize o termo "consumo unitário de materiais", sob a luz da divisão do sistema "edifício" em suas respectivas partes, a rigor se está focando o consumo unitário dos componentes utilizados nos sistemas prediais, ou seja, os tubos e as conexões. Preferiu-se utilizar o termo mais genérico por ser este o comumente utilizado no meio técnico.
} 


\subsubsection{Objetivos}

O objetivo deve indicar claramente o que o pesquisador pretende fazer ou o que pretende alcançar em sua pesquisa. Para tanto, os objetivos podem ser divididos em: principal e específicos (SILVA; MENEZES, 2001).

Para estes autores, o objetivo geral consiste na síntese do que se pretende alcançar ou realizar, ou seja, a expressão genérica do objetivo a ser alcançado, enquanto que os objetivos específicos explicitam os detalhes, ou seja, são o desdobramento do objetivo geral.

O objetivo principal da tese de doutorado a ser desenvolvida consiste em:

Elaborar um método para o prognóstico da produtividade da mão-de-obra associados à execução dos sistemas prediais hidráulicos considerando suas tarefas e subtarefas e do consumo unitário de materiais aplicáveis em dois momentos distintos em função do nível de informações disponível: na etapa de viabilidade do empreendimento e na etapa do anteprojeto ou projeto de arquitetura.

No que diz respeito ao método relacionado à produtividade da mão-de-obra, o mesmo pode ser aplicado também no momento em que os profissionais tenham em mãos o projeto executivo dos sistemas prediais hidráulicos.

Destacam-se, ainda, como objetivos específicos:

(a) elaboração do método de coleta e processamento de dados para a obtenção de indicadores de produtividade da mão-de-obra e consumo unitário de materiais nestes;

(b) elaboração de um Banco de Dados sobre indicadores de produtividade da mão-deobra, consumo unitário de materiais e fatores potencialmente influenciadores, cuja 
utilização permita realizar o prognóstico destes indicadores com base nestes fatores.

\subsubsection{Classificação da pesquisa}

Dada a diversidade de situações e opções a se pesquisar nas diversas áreas do conhecimento, as pesquisas podem ser classificadas segundo diversos critérios.

Segundo Pádua (1996) a classificação (ou tipologias de pesquisas) surgiu para auxiliar no desenvolvimento das atividades de pesquisa; no entanto, além do formalismo que uma tipologia de pesquisa requer, deve-se reconhecer que o fundamental é compreender a realidade em seus múltiplos aspectos no que diz respeito aos diferentes enfoques, níveis de aprofundamento, tipos de recursos em função dos objetivos a serem alcançados e a capacidade do próprio pesquisador para desenvolvê-los.

Gil (1991) enfatiza também que, embora se faça esta classificação, a mesma não é estanque, ou seja, as pesquisas podem assumir, ao longo do seu desenvolvimento, mais de um atributo que, somados, permitem a solução do problema de pesquisa.

Não é objetivo deste autor descrever e discutir, mesmo que de forma sucinta, as principais classificações das pesquisas. O que se pretende neste momento é apenas localizar a pesquisa objeto desta tese (Tabela 1.1) nos moldes das classificações propostas por diversos autores que tratam desta questão de forma mais aprofundada, dentre os quais se destacam Gil (1991); Marconi; Lakatos (2001); Silva; Menezes (2001) e Leopardi (2002). 
Tabela 1.1 - Classificação da pesquisa desenvolvida nesta tese

\begin{tabular}{|c|c|c|}
\hline \multicolumn{2}{|r|}{ Critérios } & \multirow{2}{*}{$\begin{array}{c}\text { Atributo relacionado a } \\
\text { esta pesquisa }\end{array}$} \\
\hline Nome & Descrição & \\
\hline Natureza & $\begin{array}{l}\text { Quanto à aplicabilidade imediata dos resultados } \\
\text { (pesquisa básica ou aplicada) }\end{array}$ & Pesquisa aplicada \\
\hline $\begin{array}{l}\text { Forma de abordagem } \\
\text { do problema }\end{array}$ & $\begin{array}{l}\text { Se as opiniões e informações obtidas são } \\
\text { traduzidas ou não em números para classificá-las e } \\
\text { analisá-las (qualitativa e quantitativa, } \\
\text { respectivamente) }\end{array}$ & Pesquisa Quantitativa \\
\hline $\begin{array}{l}\text { Sob o ponto de vista } \\
\text { dos objetivos a } \\
\text { serem alcançados }\end{array}$ & $\begin{array}{l}\text { Se as pesquisas tem um caráter: } \\
\text { - exploratório: proporcionar ao pesquisador } \\
\text { maior familiaridade com o problema de } \\
\text { pesquisa; } \\
\text { - descritiva: descrição das características } \\
\text { de determinada população ou fenômeno e, } \\
\text { em alguns casos, estabelecer relações } \\
\text { entre variáveis e; } \\
\text { explicativa: tem como foco central a } \\
\text { identificação dos fatores que determinam } \\
\text { ou contribuem para a ocorrência de } \\
\text { fenômenos, valendo-se para isto, quase } \\
\text { que exclusivamente de métodos } \\
\text { experimentais de investigação }\end{array}$ & Pesquisa Exploratória \\
\hline $\begin{array}{l}\text { Segundo as fontes } \\
\text { de informação }\end{array}$ & $\begin{array}{l}\text { Local onde a pesquisa é realizada ou fonte de } \\
\text { informação (Pesquisa de Campo, Pesquisa de } \\
\text { Laboratório, Pesquisa Bibliográfica) }\end{array}$ & $\begin{array}{l}\text { Pesquisa de Campo e } \\
\text { Pesquisa Bibliográfica }\end{array}$ \\
\hline $\begin{array}{l}\text { Sob o ponto de vista } \\
\text { dos procedimentos } \\
\text { técnicos a serem } \\
\text { adotados na } \\
\text { condução da } \\
\text { pesquisa (Métodos } \\
\text { de Pesquisa) }\end{array}$ & $\begin{array}{l}\text { De acordo com este critério, as pesquisas podem } \\
\text { ser classificadas em Pesquisa Bibliográfica, } \\
\text { Pesquisa Documental, Pesquisa Ex-post-Facto, } \\
\text { Pesquisa Participante, Levantamento (Survey), } \\
\text { Estudo de Caso, Pesquisa-Ação e Pesquisa } \\
\text { Experimental, Quase-experimental e Não- } \\
\text { Experimental. }\end{array}$ & $\begin{array}{l}\text { Pesquisa Não- } \\
\text { experimental } \\
\text { (produtividade da mão- } \\
\text { de-obra) e Pesquisa } \\
\text { Documental (consumo } \\
\text { unitário de materiais) }\end{array}$ \\
\hline
\end{tabular}

Assim, a pesquisa a ser desenvolvida na presente tese de doutorado tem um caráter de Pesquisa Aplicada, na medida em que os resultados a serem obtidos poderão ser aplicados para efeito de prognóstico rápido quanto ao consumo unitário de materiais e produtividade da mão-de-obra na fase de viabilidade do empreendimento e na etapa de anteprojeto de arquitetura e, no que diz respeito à produtividade da mão-de-obra, no controle da execução dos sistemas prediais ${ }^{11}$.

\footnotetext{
${ }^{11}$ Entende-se que na etapa de execução os profissionais já tenham em mãos o projeto executivo dos sistemas prediais, o que permite uma quantificação exata das quantidades de materiais. De posse destas quantidades, podese prognosticar e controlar a produtividade da mão-de-obra.
} 
Por se tratar de levantamento de indicadores e com possibilidades de se ter como base fundamentos estatísticos na análise dos resultados, justifica-se sua classificação em Pesquisa Quantitativa.

A pesquisa sobre produtividade da mão-de-obra será realizada durante a execução dos serviços no canteiro de obras. Portanto, trata-se de uma Pesquisa de Campo. Quanto aos indicadores de consumo unitário de materiais, estes serão obtidos pesquisando-se documentos (no, caso, os projetos dos sistemas prediais). Assim, embora se faça alguma consulta diretamente no canteiro de obras com o objetivo de se esclarecerem eventuais dúvidas, seja observando os serviços (registro fotográfico), seja consultando os envolvidos neste processo (encarregado da execução, engenheiro responsável), para esta informação em particular, a pesquisa pode ser classificada como sendo uma Pesquisa Bibliográfica, porém, com base em documentos, no caso, os projetos dos sistemas prediais.

Com relação do último critério, Gil (1991) expõe que a pesquisa experimental ocorre quando se determina um objeto de estudo e selecionam-se as variáveis que seriam capazes de influenciá-lo.

No entanto, Leopardi (2002) salienta que a Pesquisa experimental exige a manipulação e controle destas variáveis, além da utilização uma amostra aleatória no experimento. Para esta autora a pesquisa Quase-experimental é caracterizada pela existência de variáveis não controláveis ou pelo fato de a amostra não ser aleatória, enfraquecendo a possibilidade do pesquisar em fazer inferências causais. Finalmente, a pesquisa Não-experimental ocorre quando não se podem controlar as variáveis independentes.

Diante do exposto, esta pesquisa assume um caráter Não-experimental, com ênfase no prognóstico dos indicadores tanto de consumo unitário de materiais quanto dos indicadores de produtividade da mão-de-obra com base na influência de determinados 
fatores, fatores estes a serem detectados durante o desenvolvimento da pesquisa documental e de campo, respectivamente na medida em que os resultados são influenciados por fatores não controláveis pelo pesquisador e pelo fato de a amostra não ser aleatória.

\subsubsection{Método de pesquisa}

A partir do problema de pesquisa formulado e dos objetivos a serem alcançados, parte-se para o detalhamento do Método de Pesquisa, cujas etapas estão relacionadas à caracterização da pesquisa, conforme detalhamento feito no item anterior.

O Método de Pesquisa foi dividido em 3 Macro-Etapas: (A) Planejamento, (B) Coleta e Processamento e (C) Análise e Validação. Estas Macro-Etapas, assim como as etapas que as compõem, estão apresentadas na Figura 1.2, enquanto que seu detalhamento é feito na seqüência. 


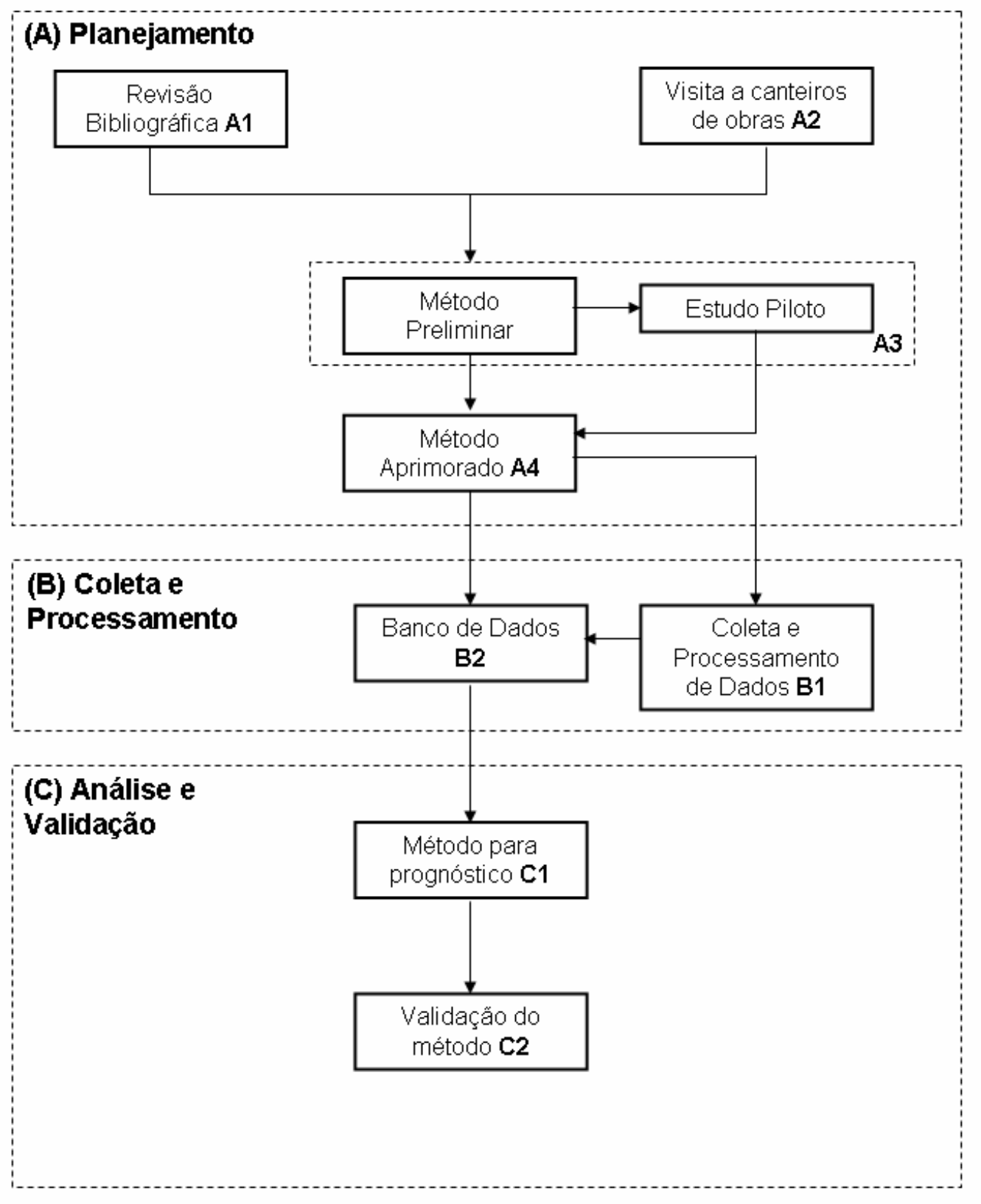

Figura 1.2 - Etapas do Método de Pesquisa

\section{(A) Planejamento}

A Macro-Etapa Planejamento foi dedicada ao maior aprofundamento do pesquisador sobre o assunto, visando o desenvolvimento dos instrumentos de coleta, assim como o embasamento teórico que permita alcançar com sucesso os objetivos propostos nesta tese. 
Este conhecimento foi inicialmente alcançado através das etapas de Revisão Bibliográfica (A1) e Visita a Canteiros de Obras (A2) para, em seguida, se aplicar o Método de Coleta preliminar em um Estudo Piloto (A3).

\section{(A1) Revisão bibliográfica}

Realizou-se uma revisão bibliográfica sobre os conceitos e definições de produtividade da mão-de-obra, consumo unitário e perdas de materiais, assim como sobre os principais trabalhos realizados no país e no exterior sobre estes assuntos. Além da conceituação, focou-se também os métodos de coleta, processamento e análise utilizados nestes trabalhos. Insere-se aqui, ainda, uma revisão bibliográfica sobre os sistemas prediais, no que se refere ao suprimento de água fria, água quente e gás, captação e escoamento de esgoto e águas pluviais, e prevenção e combate a incêndios, principalmente no que diz respeito à terminologia empregada nestes sistemas, classificação e definições, assim como os métodos executivos levando-se em consideração as tecnologias empregadas em cada sistema.

\section{(A2) Visita a canteiro de obras}

Além do conhecimento advindo da Revisão Bibliográfica, é muito importante conhecer, na prática, a execução dos sistemas prediais, principalmente no que diz respeito ao entendimento da seqüência de execução, aos procedimentos e ferramentas adotados e, principalmente, à organização da mão-de-obra. Assim, durante a estada deste pesquisador em São Paulo, teve-se a oportunidade de visitar alguns canteiros de obras nos quais os sistemas prediais se encontravam em execução. 
(A3) Elaboração preliminar do método de coleta e processamento dos dados e realização, para o caso da produtividade da mão-de-obra, do Estudo Piloto

Através das observações realizadas nas visitas em alguns canteiros de obras, sendo alguns deles, inclusive, objeto de pesquisa de campo desta tese, estruturou-se o método de coleta preliminar contendo os instrumentos de coleta de dados, assim como se investigou a melhor forma de se organizarem as informações visando tanto a facilidade de coleta de dados quanto o seu processamento.

A partir deste "Método Preliminar", o mesmo foi aplicado em um Estudo Piloto que permitiu identificar as dificuldades na aplicação dos instrumentos de coleta e da própria coleta propriamente dita, subsidiando correções necessárias para aplicação do método durante a Macro-Etapa "Coleta e Processamento dos Dados".

\section{(B) Coleta e processamento dos dados}

Esta Macro-Etapa consistiu na aplicação do método em um conjunto de obras localizadas na cidade de São Paulo e suas imediações, com o intuito de se obterem valores de produtividade da mão-de-obra, consumo unitário e perdas de materiais na execução dos sistemas prediais hidráulicos para subsidiar o Método de Prognóstico.

\section{(B1) Coleta de dados}

A coleta de dados relativa à produtividade da mão-de-obra foi realizada em 4 canteiros de obras, sendo 3 localizados na Grande São Paulo e 1 no interior deste Estado, mais especificamente na cidade de São Carlos. Quanto ao consumo unitário, tomou-se como fonte de consulta 12 projetos. Finalmente, as perdas de materiais foram analisadas, de forma exploratória, em dois canteiros de obras. 
$\mathrm{Na}$ Tabela 1.2, na seqüência, são identificadas as obras estudadas nesta tese e os respectivos indicadores coletados em cada uma.

Tabela 1.2 - Relação de obras e projetos de sistemas prediais hidráulicos analisados

\begin{tabular}{|c|c|c|c|}
\hline \multirow[t]{2}{*}{ Obra } & \multicolumn{3}{|c|}{ Indicadores } \\
\hline & $\begin{array}{l}\text { Produtividade da mão-de- } \\
\text { obra }(\mathrm{Hh} / \mathrm{m})\end{array}$ & $\begin{array}{l}\text { Consumo unitário de } \\
\text { material }\left(\mathrm{m} / \mathrm{m}^{2}\right)\end{array}$ & Perdas de material \\
\hline SP0101 & Sim & Sim & Sim \\
\hline SP0201 & Sim & Sim & Sim \\
\hline SP0301 & Sim & Sim & Não \\
\hline SP0401 & Sim & Sim & Não \\
\hline SP0501 & Não & Sim & Não \\
\hline SP0502 & Não & Sim & Não \\
\hline SP0601 & Não & Sim & Não \\
\hline SP0701 & Não & Sim & Não \\
\hline SP0801 & Não & Sim & Não \\
\hline SP0901a & Não & Sim & Não \\
\hline SP0901B & Não & Sim & Não \\
\hline SP1001 & Não & Sim & Não \\
\hline SP1002 & Não & Sim & Não \\
\hline
\end{tabular}

\section{(B2) Banco de dados}

Os dados foram organizados em um banco de dados utilizando-se o programa Microsoft Excel ${ }^{\circ}$ para sua elaboração. Na escolha deste programa levou-se em consideração a maior familiaridade deste pesquisador com o mesmo, além do fato de seus recursos permitirem, além da organização dos dados visando o seu processamento, a impressão de planilhas em um formato adequado à coleta de dados.

O processamento de dados se resume à obtenção das variáveis envolvidas no cálculo dos indicadores, conforme segue:

- Produtividade da mão-de-obra = Homens-hora / metro de tubulação;

- Consumo unitário de tubos = Metros de tubos / Área do apartamento-tipo ou metros de tubos / ponto de consumo ou captação (depende do tipo de sistema 
predial; se for de esgoto, por exemplo, é captação, se for água quente, por exemplo, é consumo);

- Consumo unitário de conexões = conexões / metro de tubulação ou conexões $/$ área do apartamento-tipo.

Evidentemente, outras informações serão necessárias e processadas, como as que se relacionam aos fatores influenciadores destes indicadores.

Finalmente, há que se destacar que os resultados a serem obtidos não se referem aos sistemas prediais como um todo e sim as suas partes (tarefas e subtarefas, para o caso da produtividade da mão-de-obra, e subsistemas, para o caso do consumo unitário teórico de materiais).

\section{(C) Análise e verificação}

Nesta Macro-Etapa, de posse das informações contidas no banco de dados, partiu-se para a elaboração do método de prognóstico da produtividade da mão-de-obra e consumo unitário de materiais e sua verificação.

\section{(C1) Método para o prognóstico do consumo unitário de materiais e produtividade da mão-de-obra}

Nesta etapa, através de recursos estatísticos aplicados aos valores de produtividade e consumo obtidos na etapa anterior, levando-se em consideração os fatores de contexto e conteúdo detectados, faz-se a elaboração dos modelos de prognóstico da produtividade da mão-de-obra e consumo unitário de materiais nestes sistemas prediais. 


\section{(C2) Verificação dos Métodos para o Prognóstico}

Os métodos de prognóstico do consumo de materiais (simplificado e analítico) e produtividade da mão-de-obra serão aplicados a um caso real. Os resultados prognosticados de consumo de materiais (quantidade de tubos e conexões) utilizandose os métodos simplificado e analítico serão comparados com o consumo de materiais levantado com base no projeto específico de sistemas prediais elaborados para o caso real em questão.

No que se refere à mão-de-obra, com base nas quantidades de serviços a serem executadas de acordo com o levantamento feito nos projetos específicos do caso real, será feita uma comparação entre a quantidade de homens-hora demandada, obtida aplicando-se o método proposto, e quantidade demandada, obtida utilizando-se os indicadores de produtividade da mão-de-obra apresentados no TCPO (2003).

\subsection{Estrutura do texto}

O desenvolvimento da tese se dá ao longo de 9 capítulos, contando com este, conforme ilustrado na Tabela 1.3.

Além dos capítulos apresentados nesta tabela, este texto é complementado por 4 apêndices e por 2 anexos:

APÊNDICEA - Exemplo de Planilha "Fonte": montagem de ramais de esgoto sanitário/ventilação sob o teto - comprimento de tubulação;

APÊNDICE B - Exemplo de planilha de coleta de dados em obra: montagem de ramais de esgoto sanitário/ventilação sob o teto; 
APÊNDICE C - Planilhas de caracterização da edificação e dos sistemas prediais;

APÊNDICE D - Quantitativos de projeto.

ANEXO A - Projetos dos Sistemas Prediais das edificações/obras analisadas;

ANEXO B - Projeto dos Sistemas Prediais da obra SP1101 utilizados para a verificação do Método de Prognóstico elaborado.

Tabela 1.3 - Apresentação da estruturação dos capítulos

\begin{tabular}{|c|c|c|}
\hline Capítulo & Conteúdo & $\begin{array}{l}\text { Etapa do método } \\
\text { de pesquisa }\end{array}$ \\
\hline Capítulo 1 & Justificativa, objetivo e metodologia de pesquisa para atingi-lo. & - \\
\hline Capítulo 2 & $\begin{array}{l}\text { Conceituação sobre produtividade da mão-de-obra, consumo } \\
\text { unitário de materiais e perdas de materiais. }\end{array}$ & $\mathrm{A} 1, \mathrm{~A} 2$ \\
\hline Capítulo 3 & $\begin{array}{l}\text { Conceituação sobre sistemas prediais de suprimento de água } \\
\text { fria, água quente, gás, esgoto sanitário e águas pluviais e } \\
\text { prevenção e combate a incêndios. }\end{array}$ & $\mathrm{A} 1, \mathrm{~A} 2$ \\
\hline Capítulo 4 & $\begin{array}{l}\text { Discussão do Método de Coleta de dados para o cálculo dos } \\
\text { indicadores de produtividade da mão-de-obra e consumo } \\
\text { unitário de materiais. }\end{array}$ & $\mathrm{A} 4, \mathrm{~B} 1$ \\
\hline Capítulo 5 & $\begin{array}{l}\text { Caracterização dos estudos de caso quanto ao tipo de } \\
\text { edificação, tipos de sistemas prediais e método executivo e } \\
\text { composição das equipes de trabalho na execução dos } \\
\text { sistemas prediais hidráulicos. }\end{array}$ & $\mathrm{B} 1, \mathrm{~B} 2$ \\
\hline Capítulo 6 & $\begin{array}{l}\text { Resultados sobre indicadores de consumo unitário de } \\
\text { materiais. }\end{array}$ & B2 \\
\hline Capítulo 7 & $\begin{array}{l}\text { Resultados sobre indicadores de produtividade da mão-de- } \\
\text { obra. }\end{array}$ & B2 \\
\hline Capítulo 8 & $\begin{array}{l}\text { Método para prognóstico da produtividade da mão-de-obra e } \\
\text { consumo unitário de materiais. }\end{array}$ & $\mathrm{C} 1$ \\
\hline Capítulo 9 & $\begin{array}{l}\text { Considerações finais, validação do modelo proposto e } \\
\text { sugestões para futuros trabalhos. }\end{array}$ & $\mathrm{C} 2$ \\
\hline
\end{tabular}




\section{Capítulo 2}

\section{PRODUTIVIDADE DA MÃO-DE- OBRA E CONSUMO UNITÁRIO DE MATERIAIS}

Neste capítulo são apresentados os principais conceitos e fundamentos sobre produtividade da mão-de-obra e consumo unitário de materiais. É dada ênfase nas definições, classificações e nomenclatura.

\subsection{Aspectos conceituais relacionados à produtividade da mão-de-obra}

\subsubsection{Definição}

Associando as várias interpretações do termo, Maeda (2002) define produtividade como sendo a combinação entre a efetividade (quão bem os resultados são alcançados) e a eficiência (quão bem os recursos são utilizados na busca dos resultados) de um determinado sistema produtivo.

Numa forma mais direta, a produtividade consiste na relação entre as entradas de um processo (materiais, mão-de-obra etc.) e as saídas do mesmo $\left(\mathrm{m}^{2}\right.$ de alvenaria, metros de tubulações etc.). 
Restringindo esta conceituação para a mão-de-obra, a produtividade consiste na eficiência da transformação do esforço humano em serviços de construção, conforme ilustrado na Figura 2.1 (SOUZA, 2001).

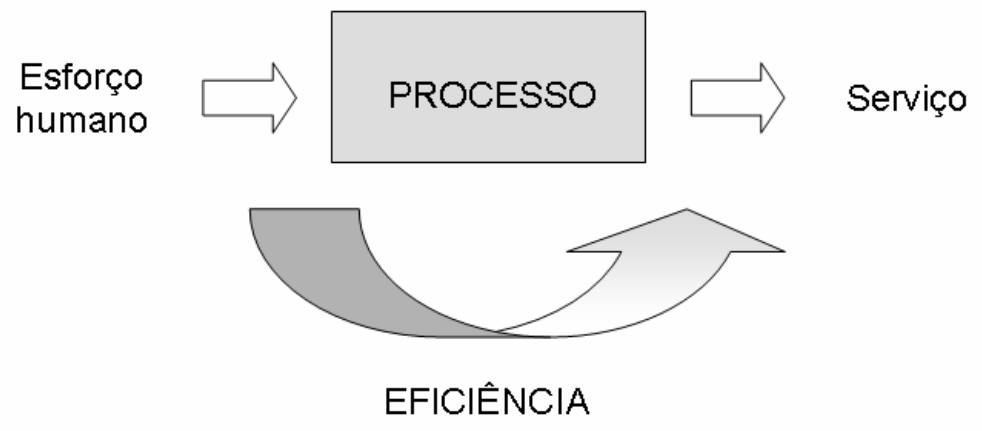

FIGURA 2.1 - Produtividade da mão-de-obra (SOUZA, 2001)

\subsubsection{Modelo dos Fatores}

Entendendo-se produtividade como sendo a eficiência em se transformar entradas em saídas num processo produtivo (SOUZA, 1998), o método para a sua medição e previsão será baseado no modelo proposto por Thomas; Yiakoumis (1987), denominado "Modelo dos Fatores", adaptado e aperfeiçoado para a situação brasileira em diversas dissertações elaboradas no âmbito do Programa de Pós-Graduação de Engenharia de Construção Civil e Urbana da USP. ${ }^{12}$

De acordo com este modelo, a produtividade da mão-de-obra é avaliada no âmbito da equipe de trabalho levando-se em consideração o efeito da curva de aprendizagem de atividades repetitivas, assim como os outros fatores que interferem no seu valor.

\footnotetext{
${ }^{12}$ Embora tenha sido desenvolvido para a avaliação da produtividade da mão-de-obra, o mesmo será estendido à avaliação e prognóstico do consumo unitário de materiais, por entender que as variações de consumo, da mesma forma que a produtividade da mão-de-obra, são decorrentes da ação de determinados fatores.
} 
Tais fatores são divididos em duas categorias: uma relacionada ao conteúdo do trabalho e outra relacionada ao contexto no qual o trabalho está sendo realizado (THOMAS; SMITH, 1990). Segundo estes autores, a primeira categoria abrange as características físicas do trabalho, ou seja, a especificação dos materiais, os detalhes de projeto; enquanto que a segunda categoria diz respeito ao ambiente de trabalho, aos aspectos organizacionais e gerenciais, além de incluir também as condições atmosféricas, disponibilidade de materiais e equipamentos, entre outros aspectos.

Em outras palavras, a realização do trabalho por uma equipe sofre interferência de certa quantidade de fatores que, por sua vez, afetam o seu desempenho aleatória ou sistematicamente (THOMAS; YIAKOUMIS, 1987). Assim, o somatório ou o efeito cumulativo das interferências causadas por estes fatores gera uma curva que exprime a produtividade real, cuja forma pode ser muito irregular, de difícil interpretação.

No entanto, segundo estes autores, se os efeitos destes fatores puderem ser extraídos matematicamente da curva real, obter-se-á uma curva que representará a produtividade de referência. Esta curva representará o desempenho básico do serviço avaliado, dentro de certas condições de referência, incluindo uma componente resultante de eventuais melhorias oriundas das operações repetitivas (curva de aprendizagem). Assim, a forma e a magnitude da curva real de produtividade dependerão do número de fatores relacionados às condições ambientais do canteiro de obras, métodos construtivos e aspectos relacionados à construtibilidade.

As idéias preconizadas neste modelo podem ser representadas graficamente na Figura 2.2, na qual se observa a curva teórica de produtividade ao longo do tempo, assim como a curva de produtividade real levando-se em consideração a presença e intensidade de diversos fatores. 


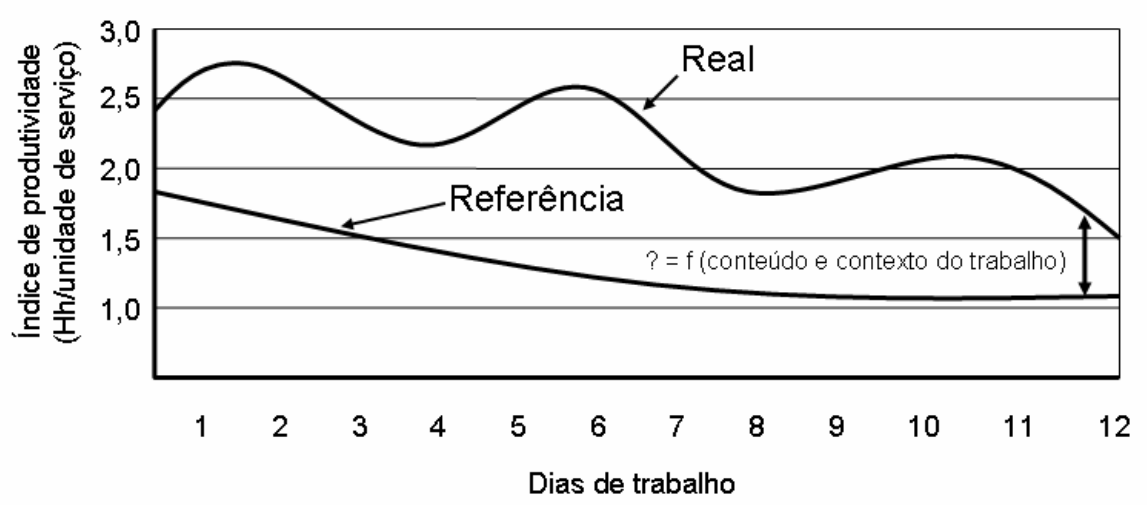

Figura 2.2 - Representação gráfica do Modelo dos Fatores. Fonte: SOUZA (1996)

Além destes fatores, destaca-se uma outra categoria relacionada às anormalidades que ocorrem ao longo da execução dos trabalhos que faz com que a produtividade também varie.

Este modelo vem sendo aprimorado e aplicado em diversos serviços através da realização de diversas pesquisas no âmbito do programa de Pós-Graduação do Departamento de Engenharia de Construção Civil, pesquisas estas, sob orientação do Prof. Dr. Ubiraci Espinelli Lemes de Souza, que trazem a nomenclatura, definições e procedimentos adaptados à construção civil nacional.

\subsubsection{Indicadores para mensuração da produtividade da mão-de-obra}

Considerando o canteiro de obras como um sistema produtivo, a produtividade consiste na relação entre as entradas de um processo (materiais, mão-de-obra etc.) e as saídas do mesmo, como por exemplo, $\mathrm{m}^{2}$ de alvenaria, metros de tubulações etc. e, no que diz respeito especificamente à produtividade da mão-de-obra, esta é mensurada através do indicador denominado Razão Unitária de Produção (RUP), termo introduzido no país através de trabalhos sobre o assunto realizados por Souza (1996) que relaciona os homens-hora $(\mathrm{Hh})$ despendidos (entradas do processo) às 
quantidades de produtos obtidos (Quantidade de serviço), ou seja, as saídas do processo. Matematicamente, a RUP é calculada de acordo com a equação 2.1:

$$
R U P=\frac{H h}{Q S}
$$

Onde:

$$
\begin{aligned}
& H h \quad \text { Homens-hora despendidos na execução do serviço } \\
& \text { QS } \quad=\quad \begin{array}{l}
\text { Quantidade de serviço executado pela mão-de-obra em determinado } \\
\text { tempo }
\end{array}
\end{aligned}
$$

Para o cálculo da RUP considera-se a quantidade "líquida" de serviço executado (para o caso de um revestimento, onde a quantidade de serviço é medida em área, por exemplo, não se considera a área das aberturas; no caso dos sistemas prediais, onde a quantidade de serviço é medida em metros de tubulação, não se considera qualquer expectativa/percentual de perdas embutida nos orçamentos, ou seja, são considerados os metros de tubulação efetivamente instalados na edificação) e o tempo em que os operários estiveram disponíveis para o trabalho, ou seja, são considerados tanto os tempos produtivos quanto improdutivos. Da mesma forma não são consideradas, neste cômputo, as horas-prêmio recebidas pelos operários.

\subsubsection{Classificação dos indicadores de produtividade da mão-de-obra}

Segundo Souza (2001), o indicador de produtividade pode ser classificado de acordo com a abrangência (tipo de mão-de-obra analisado) e o intervalo de tempo relacionado às entradas e saídas. Com relação ao primeiro critério, a RUP pode ser classificada em RUP Oficial (quando é associada à mão-de-obra dos oficiais envolvidos 
diretamente na produção), RUP Direta (quando, além dos homens-hora correspondentes aos oficiais, incluem-se também as horas correspondentes aos ajudantes envolvidos diretamente com a produção) e finalmente, a RUP Global, que envolve toda a mão-de-obra relacionada com o serviço em análise.

Quanto ao intervalo de tempo, tem-se a RUP Diária (representa a produtividade diária dos envolvidos no processo), RUP Cumulativa (corresponde à produtividade acumulada durante um período de tempo) e RUP Cíclica, adotada quando o serviço possui ciclos de produção bem definidos (por exemplo, a cada pavimento, a cada semana etc.). Ainda, segundo este autor, a RUP Diária indica o efeito dos fatores presentes no dia de trabalho, enquanto que a RUP Cumulativa indica a tendência de desempenho do serviço, amenizando, assim, os efeitos ocasionados pelos dias anormais ocorridos durante o período de execução do serviço analisado.

Além destas RUP's, destaca-se também a RUP Potencial que corresponde à mediana dos valores de RUP Diária menores ou iguais à RUP Cumulativa final. De acordo com este autor, a RUP Potencial constitui em "um valor de RUP Diária associado à sensação de bom desempenho e que, ao mesmo tempo, mostra-se factível em função dos valores de RUP Diária detectados". Na Tabela 2.1 apresenta-se um exemplo de cálculo dos vários tipos de RUP para o caso da execução das prumadas de cobre. 
Tabela 2.1 - Exemplo de cálculo das RUP's: execução de prumadas de cobre

\begin{tabular}{|c|c|c|c|c|c|c|c|c|}
\hline \multirow{2}{*}{ Dia } & \multicolumn{2}{|c|}{ Diário } & \multicolumn{2}{c|}{ Cumulativo } & \multicolumn{4}{c|}{ Produtividade (Hh/m) } \\
\cline { 2 - 8 } & Hh & QS & Hh & QS & $\begin{array}{c}\text { RUP } \\
\text { Diária }\end{array}$ & RUP Cum & $\begin{array}{c}\text { RUP Diária } \leq \\
\text { RUP Cum }\end{array}$ & RUP Pot \\
\hline $\mathbf{1}$ & 9,00 & 41,98 & 9,00 & 41,98 & 0,21 & 0,21 & 0,21 & 0,20 \\
\cline { 1 - 8 } & 8,00 & 41,98 & 17,00 & 83,96 & 0,19 & 0,20 & 0,19 & \\
\cline { 1 - 8 } & 9,00 & 41,98 & 26,00 & 125,94 & 0,21 & 0,21 & 0,21 & 0,13 \\
\hline $\mathbf{4}$ & 3,60 & 27,64 & 29,60 & 153,58 & 0,13 & 0,19 & & \\
\hline $\mathbf{5}$ & 9,00 & 14,34 & 38,60 & 167,92 & 0,63 & 0,23 & & \\
\hline
\end{tabular}

\subsection{Aspectos conceituais relacionados a perdas e consumo unitário}

\subsubsection{Consumo unitário de materiais}

O conceito relativo ao consumo unitário deriva da definição de produtividade no uso de recursos físicos num processo produtivo, isto é, refere-se à eficiência na transformação de certa quantidade de material (por exemplo, a massa de aço realmente utilizada) em certo montante de produtos gerados (por exemplo, a armadura descrita nos projetos). Portanto, o consumo unitário pode ser calculado de acordo com a expressão 2.2 , a seguir.

$$
C U M=\frac{Q M R}{Q S}
$$

onde

$$
\begin{array}{ll}
Q M R & =\text { Quantidade de material empregado em determinado serviço ou produto } \\
Q S & =\quad \text { Quantidade de serviço ou produto executado }
\end{array}
$$


No caso dos sistemas prediais, é comum expressar o consumo unitário como sendo a relação entre a quantidade realmente utilizada de material (metros de tubos) e a quantidade de serviço executado (metros de tubos).

Por sua vez, o denominador da expressão 2.2 pode ser desmembrado em duas parcelas: consumo unitário teórico, que se refere à quantidade de serviço medida em projeto e uma parcela relativa ao consumo excedente de material, denominada perdas. Este raciocínio é ilustrado na expressão 2.3.

$$
C U M=C U M_{\text {Teórico }} x\left(1+\frac{\text { Perdas }}{100}\right)
$$

onde:

$$
\begin{array}{ll}
\text { CUM } & =\begin{array}{l}
\text { Cóórico }= \\
\text { projetos específicos de sistemas prediais }
\end{array} \\
\text { Perdas }= & \begin{array}{l}
\text { Quantidade excedente de material em relação à quantidade } \\
\text { especificada nos projetos de sistemas prediais }
\end{array}
\end{array}
$$

A segunda parcela está relacionada à execução dos serviços nos canteiros de obras, conforme exposto no item 2.2.2. Nesta tese, porém, foca-se o consumo unitário teórico, ou seja, aquele relacionado ao projeto e não ao canteiro de obras, embora se tenha realizado um estudo exploratório sobre perdas de tubulações em duas obras.

Mais do que isto, adota-se uma postura inovadora no que diz respeito ao denominador do consumo unitário teórico. Enquanto na postura tradicional se adota o metro de tubulação como parâmetro, nesta tese propõe-se utilizar o metro quadrado de apartamento-tipo por ser este o parâmetro de entrada na composição dos orçamentos (área de alvenaria pela área de piso, $\mathrm{m}^{3}$ de concreto por área de piso etc.). 


\subsubsection{Perdas de materiais}

Embora o foco da tese seja o consumo unitário teórico de materiais tendo-se como base os projetos de sistemas prediais, aborda-se, aqui, a conceituação relativa à ocorrência de perdas de materiais nos canteiros de obras, uma vez que se realizou um estudo exploratório em duas obras.

Ao se comparar a quantidade de material teoricamente necessária (QMT) com a quantidade realmente utilizada (QMR) determinam-se as perdas de materiais.

Matematicamente, o seu cálculo percentual é feito de acordo com a expressão 2.4, a seguir.

$$
\operatorname{Perda}(\%)=\left[\frac{Q M R-Q M T}{Q M T} \times 100\right]
$$

Esta quantidade de material utilizada em excesso pode acontecer sob três diferentes naturezas: (a) por furto; (b) incorporação de materiais à edificação; e (c) entulho (Figura 2.3)

O furto, ou extravio, normalmente não é muito elevado em obras de grande porte, uma vez que nestas existem, em geral, procedimentos de controle (qualitativos e quantitativos) de recebimento dos materiais.

A incorporação de materiais em excesso nas edificações ocorre, principalmente, para os materiais utilizados em serviços que exigem a moldagem in loco, como é o caso das estruturas de concreto armado e revestimentos argamassados, por exemplo.

Finalmente, o entulho se constitui no "lixo que sai", ou seja, é a parcela mais visível das perdas de materiais. Segundo Brito Filho (1999), na cidade de São Paulo, somente a indústria da construção civil gera $90.000 \mathrm{~m}^{3}$ de entulho por mês, considerando-se apenas o material que chega a aterros oficiais. 


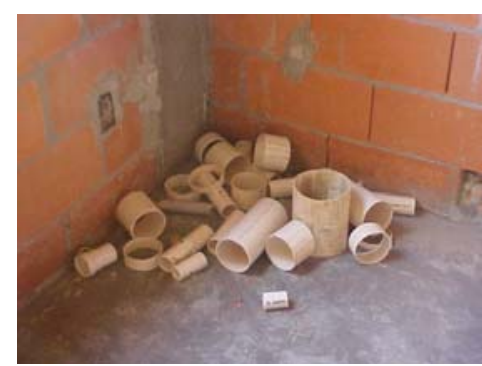

(a)

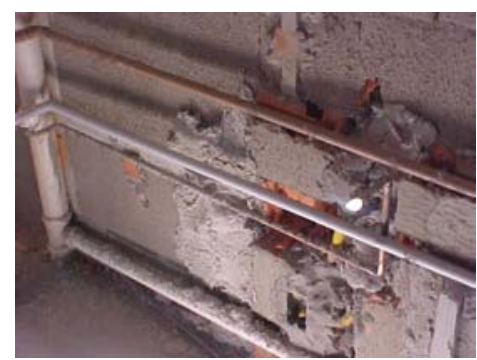

(b)

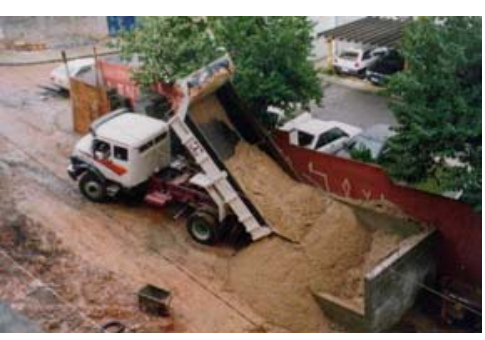

(c)

Figura 2.3 - Exemplos das diferentes naturezas das perdas: (a) entulho na execução de sistemas prediais; (b) incorporação de argamassa para embutir as tubulações; (c) material faltante na entrega de areia

\subsubsection{Classificação das perdas}

As perdas de materiais podem ser classificadas segundo 4 categorias, quais sejam: a) forma de manifestação; b) momento de incidência na etapa de Produção, c) suas causas e d) sua origem (ANDRADE, 1999).

\subsubsection{Segundo sua forma de manifestação}

Conforme indicado pelo próprio nome, esta classificação preocupa-se com a caracterização quanto à maneira em que as perdas ocorreram. Como exemplos, podem ser citados: argamassa saindo por rasgos na embalagem; cimento empedrado nos sacos; areia carreada do estoque pela chuva; pontas de aço não reaproveitáveis; argamassa endurecida ao pé da parede revestida; gesso endurecido na caixa do gesseiro entre outros.

\subsubsection{Segundo o momento de incidência na etapa de produção}

Analisando o fluxo dos materiais nos canteiros de obras, percebe-se que os mesmos passam por diversas etapas até chegarem ao destino final, ou seja, são recebidos e 
inspecionados, estocados, processados e, por fim, aplicados, sendo que entre cada etapa os mesmos são transportados.

Ao levantamento de todas estas etapas de um serviço em estudo, além da representação do relacionamento entre elas, denomina-se fluxograma dos processos, o qual se constitui numa ferramenta importante para o entendimento das ações necessárias visando a melhoria do seu desempenho (SOUZA, 1997).

Note-se, no entanto, que o número de etapas dependerá do tipo de material analisado. No caso do concreto, por exemplo, identificam-se apenas as etapas de recebimento, transporte e aplicação final, enquanto que, para os blocos, além destas etapas já descritas, insere-se também a etapa de estocagem e processamento intermediário, sendo esta última resultado da necessidade de se realizar o corte dos mesmos para acertos, por exemplo, de modulação da alvenaria.

Em todas estas etapas podem ocorrer perdas cuja intensidade e forma de manifestação dependerá do tipo de material analisado e do serviço no qual o mesmo é utilizado e, evidentemente, da forma através da qual se realiza a sua gestão no canteiro de obras.

\subsubsection{Segundo suas causas}

O entendimento sobre em que etapa do fluxograma dos processos as perdas ocorrem, assim como a sua forma de manifestação, constitui-se no primeiro passo para a implementação de ações voltadas a sua redução. No entanto, este entendimento deve passar também pela identificação da causa da sua ocorrência, ou seja, a razão imediata para sua ocorrência. 
Note-se que, para uma determinada forma de manifestação, podem-se supor diferentes causas. Assim é que a presença de entulho de blocos, em um canteiro de obras, pode ter como causas: o transporte inadequado deste material utilizando-se jericas em lugar de carrinhos com base plana; uso de ferramentas impróprias, por exemplo, cortando blocos com a colher de pedreiro em lugar de usar uma serra elétrica com disco correto; desmoronamento de um estoque por choque com um equipamento de transporte etc.

\subsubsection{Segundo sua origem}

Além da causa, interessa também saber a origem do problema, ou seja, uma decisão (ou a falta dela) ocorrida na própria etapa geradora do resíduo ou em etapa anterior, que tenha induzido a causa e, conseqüentemente, a geração das perdas. É importante ressaltar que se podem indicar origens em diferentes etapas do empreendimento.

Assim, a geração de entulho de blocos (uma das naturezas das perdas de materiais) em função do corte inadequado dos mesmos, pode ter como origem a não previsão de coordenação modular entre as dimensões das paredes e dos blocos, o que seria relativo à etapa de Projeto ou a não disponibilização do equipamento adequado para operário, associada à etapa de Produção.

\subsection{Analogia entre os indicadores de produtividade da mão-de-obra e perdas de materiais}

Conforme destacado anteriormente, os indicadores de produtividade da mão-de-obra e consumo unitário de materiais são influenciados por fatores, sejam eles relacionados ao conteúdo do trabalho e ao contexto do trabalho, além da ocorrência de anormalidades. 
Para se fazer uma análise mais acurada destes indicadores deve-se desmembrá-los nas suas partes menores com o objetivo de inferir a cada uma destas partes estes fatores. No caso específico da mão-de-obra, o indicador mensurador deste recurso é a RUP, que pode ser diária, cumulativa e potencial e, em particular, estas duas últimas se relacionam através da seguinte expressão:

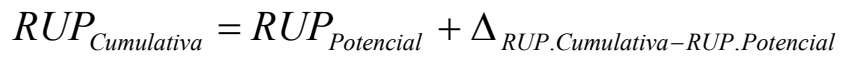

Os fatores de conteúdo e contexto se aplicam à RUP Potencial, enquanto que a diferença entre a RUP Cumulativa e RUP Potencial é influenciada pela ocorrência de anormalidades, tais como a falta de material, necessidade de retrabalho, entre outras.

Este mesmo raciocínio pode ser feito com relação ao indicador de consumo unitário de materiais, recorrendo-se à expressão 2.5 apresentada anteriormente. Por analogia, a RUP Potencial se equivaleria ao $C U M_{\text {Térico }}$ enquanto que o $\Delta_{R U P \text {.Cumulativa-RUP.Potencial }}$ se equivaleria às Perdas. 
Neste capítulo são apresentados os principais sistemas prediais de uma edificação, com ênfase para aqueles que são objetos de pesquisa para a avaliação da produtividade da mão-de-obra e consumo unitário de materiais. Para cada sistema predial, faz-se a sua definição, são contemplados os principais requisitos de desempenho e sua classificação segundo diversos critérios.

O entendimento destes sistemas é premissa básica para detectar os possíveis fatores influenciadores da produtividade da mão-de-obra, assim como para estabelecer os procedimentos de coleta de informações para o cumprimento dos objetivos propostos. O projeto de sistemas prediais também é tratado neste capítulo, porém de forma qualitativa, não havendo a preocupação com o seu dimensionamento.

\subsection{Definição de sistemas prediais}

Sendo os sistemas prediais objeto de pesquisa para a avaliação da produtividade da mão-de-obra e consumo unitário de materiais, torna-se necessário defini-los, num primeiro instante, na sua forma mais ampla, para, em seguida, partir-se para a definição de cada sistema predial envolvido neste trabalho, o que será feito na medida em que os mesmos forem apresentados. 
Dentre as diversas partes de uma edificação, existem várias que estão intimamente relacionadas às atividades desenvolvidas pelos usuários que, por sua vez, estão relacionadas ao tipo de insumos necessários a sua realização.

Assim, a edificação deve estar provida de diversos serviços que atendam plenamente as funções para as quais foram projetados e às necessidades dos usuários, sendo mais complexos quanto maior for o porte da edificação e a diversidade de funções inseridas na mesma ${ }^{13}$. Este conjunto de serviços recebe a denominação de instalações prediais (FRANCO; BARROS, 1993).

Sob um aspecto amplo, dentre os insumos necessários para a realização destas atividades destacam-se a água e a energia, enquanto que, dentre os serviços requeridos, destacam-se os serviços de segurança ao fogo e patrimonial, conforto térmico, acústico, visual e tátil, transporte e circulação, comunicação e informação e automação (Gonçalves, 1994), resultando, portanto, em instalações de água fria, instalações elétricas e assim sucessivamente.

O termo "instalações prediais" foi amplamente utilizado para designar estes serviços até pouco tempo, podendo-se citar publicações que o utilizaram, tais como Gonçalves (1978); Amorim (1989) e, até mesmo, as normas específicas da ABNT reformuladas recentemente que tratam do assunto, dentre as quais se cita a NBR 5626 (ABNT, 1998).

Embora Gonçalves (1978) não utilizasse à época o termo "sistemas" em detrimento ao de "instalações", o autor já enfatizava a necessidade da integração entre as partes da edificação ao se elaborar o projeto relacionado ao suprimento de água fria, em uma alusão de tratar esta área do conhecimento de forma sistêmica.

\footnotetext{
${ }^{13}$ Soma-se a isto também, as características regionais e culturais nas quais os mesmos estão inseridos (GONÇALVES, 1994).
} 
Esta postura se tornou mais evidente nos vários trabalhos realizados pelo grupo de Ensino e Pesquisa em Engenharia de Sistemas Prediais do Programa de PósGraduação em Engenharia de Construção Civil da Escola Politécnica da USP, transcendendo os seus limites e permeando este conceito tanto no meio acadêmico quanto fora do mesmo.

A justificativa para tal postura se deve ao aumento da complexidade destas instalações e da necessidade de se abordá-las de forma diferenciada, não analisando somente o seu aspecto físico, mas também o aspecto funcional (GONÇALVES, 1994).

Nesta nova abordagem, as instalações prediais devem ser consideradas como um dos subsistemas da edificação que se relaciona com os outros subsistemas e cujas soluções para os problemas devem ser pensadas e adotadas considerando-se o todo e não somente as partes.

Assim, as instalações são promovidas a sistemas (ou subsistemas) de uma edificação, cuja definição está relacionada a uma hierarquização da edificação levando-se em consideração as suas partes.

Portanto, sob a visão sistêmica proposta por Gonçalves (1994), os sistemas ${ }^{14}$ prediais podem ser definidos como sendo "sistemas físicos, integrados a um edifício e que têm por finalidade dar suporte às atividades dos usuários, suprindo-os com os insumos prediais necessários e propiciando os serviços requeridos".

\footnotetext{
${ }^{14}$ A utilização dos termos "sistemas" e "subsistemas" está relacionada a uma divisão hierárquica da edificação em suas partes. Sob o ponto de vista amplo, a edificação pode ser considerada como sendo um sistema formado por vários subsistemas interligados entre si, onde se enquadram os serviços de suprimento de água, energia elétrica entre outros. Esta mesma hierarquização pode ser feita ao se analisar especificamente estes serviços, podendo-se atribuir aos mesmos o status de "sistemas" e as partes que o compõem de subsistemas. Neste trabalho, como forma de reforçar a necessidade de se entender e tratar os problemas e soluções inerentes a esta área do conhecimento de forma sistêmica, cada um receberá a denominação de sistemas, resultando assim em sistema predial de suprimento de água fria, sistema predial de suprimento de água quente etc.
} 
No entanto, atualmente, a atividade construtiva transcende os esforços empreendidos pelos agentes da cadeia produtiva da Indústria da Construção Civil no sentido de oferecer um produto com qualidade e a um preço competitivo.

Na visão de Santos (2002), a importância dos sistemas prediais na construção civil não está relacionada apenas às necessidades relativas à higiene e saúde do usuário da edificação e sim, com as evolutivas noções de conforto impostas por um dinâmico comportamento social, assim como com a contribuição para a promoção da sustentabilidade do habitat.

Contribuir para a promoção da sustentabilidade do habitat, no que diz respeito aos sistemas prediais, significa utilizar racionalmente os insumos abrangidos pelo mesmo e, em particular em relação à água, várias ações podem ser exemplificadas neste sentido, tais como: ações de uso racional da água (utilização de aparelhos economizadores de água, adoção de medição individualizada, maior conscientização do usuário, controle das perdas de água) e utilização de fontes alternativas de água, tais como o uso da água cinza, água da chuva, água subterrânea e água envasada em caminhões pipa [SANTOS (2002), OLIVEIRA (1999)].

Portanto, ao se considerar tanto o conceito de visão sistêmica aplicado aos sistemas prediais, assim como a inserção do conceito de desenvolvimento sustentável, os sistemas prediais podem ser definidos como "sistemas físicos, integrados a um edifício, e que têm por finalidade dar suporte às atividades dos usuários, suprindo-os com os insumos prediais necessários e propiciando os serviços requeridos de forma a contribuir com a sustentabilidade do habitat." 


\subsection{Classificação dos sistemas prediais}

A classificação dos sistemas prediais está relacionada ao tipo de insumo ou serviço requerido pelo usuário da edificação. Desta forma, a cada insumo e/ou serviço necessário, pode-se associar um sistema predial com características próprias (materiais, tipos de conexões, traçados, inserção no cronograma de execução da obra etc.) e com requisitos de desempenho distintos. Na Tabela 3.1 estão reunidos os principais tipos de sistemas prediais em função do tipo de insumo e/ou serviço requerido pelo usuário da edificação.

Tabela 3.1 - Tipos de sistemas prediais em função do insumo e/ou serviço requerido pelos usuários (GONÇALVES, 1994)

\begin{tabular}{|l|l|}
\hline Serviços/insumos & Sistemas prediais \\
\hline Energia & $\begin{array}{l}\text { Suprimento de energia elétrica } \\
\text { Suprimento de gás }\end{array}$ \\
\hline Água & $\begin{array}{l}\text { Suprimento de água } \\
\text { Coleta de esgotos } \\
\text { Coleta de águas pluviais }\end{array}$ \\
\hline Segurança & $\begin{array}{l}\text { Proteção e combate a incêndio } \\
\text { Segurança patrimonial }\end{array}$ \\
\hline Conforto & $\begin{array}{l}\text { Condicionamento de ar } \\
\text { lluminação }\end{array}$ \\
\hline Transporte & Transportes mecanizados \\
\hline Comunicações & $\begin{array}{l}\text { Comunicação interna } \\
\text { Telecomunicação }\end{array}$ \\
\hline Automação & Automação predial \\
\hline
\end{tabular}

No que diz respeito aos sistemas prediais relacionados à água, é comum referenciálos sob a denominação de sistemas prediais hidráulicos e sanitários, envolvendo, inclusive, os aparelhos/equipamentos sanitários ${ }^{15}$.

\footnotetext{
${ }^{15}$ O sistema de aparelhos/equipamentos sanitários tem como finalidade, além de proporcionar o uso da água nos pontos de consumo, coletar os dejetos e a água utilizada. Este sistema abrange, além das louças sanitárias, os metais e demais acessórios que possibilitam a descarga de água, tais como torneiras, válvulas de descarga etc. (YWASHIMA, 2005). O estudo deste sistema não faz parte do escopo deste presente trabalho.
} 
Dentre os sistemas prediais apresentados na Tabela 3.1, neste capítulo são discutidos os sistemas prediais relacionados à utilização da água e da energia, sendo este último insumo delimitado ao gás, seja ele natural ou liquefeito de petróleo $(G L P)^{16}$, conforme ilustrado na Figura 3.1.

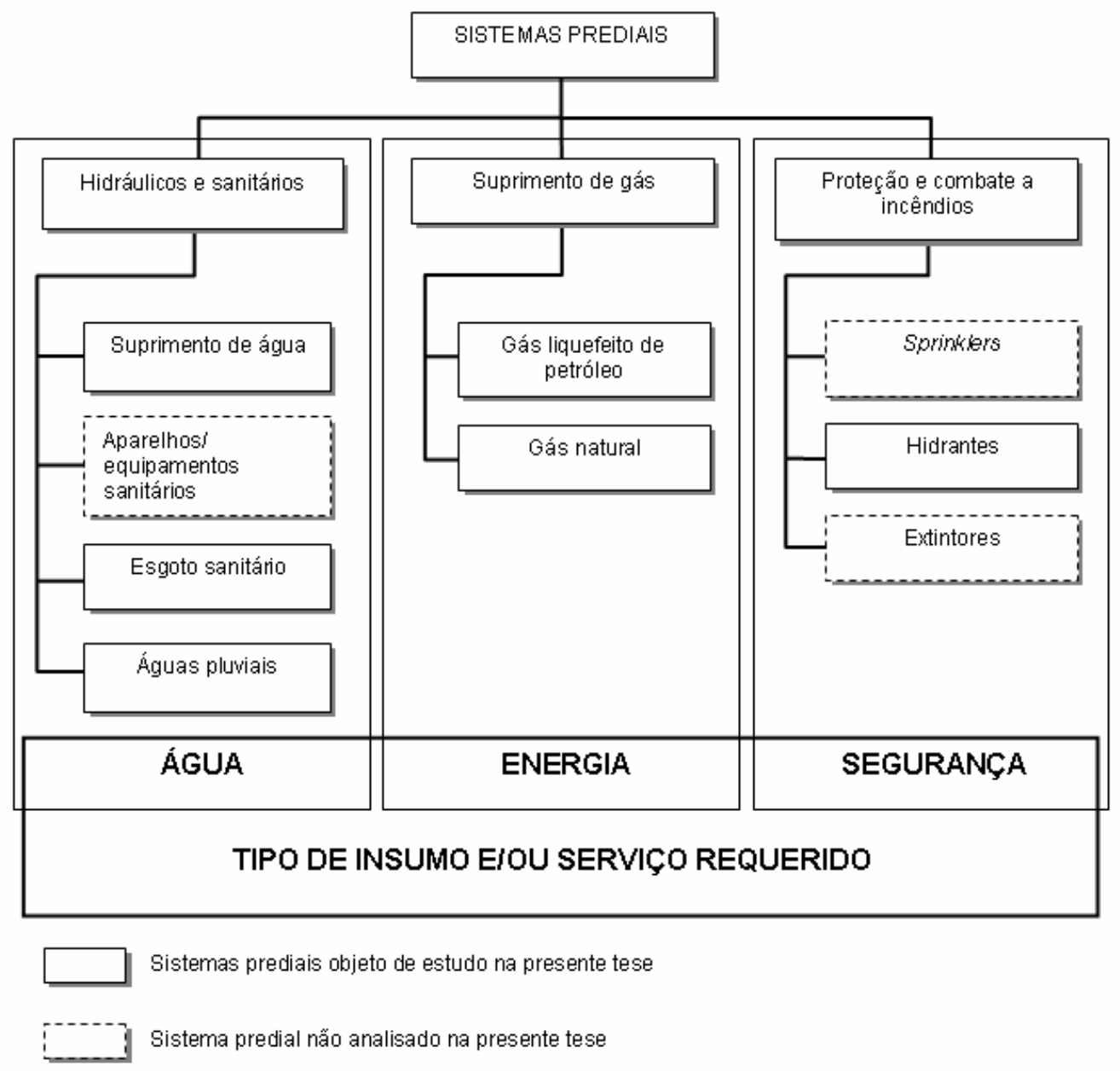

Figura 3.1 - Classificação dos sistemas prediais em função do tipo de insumo/serviço requerido pelos usuários

\footnotetext{
${ }^{16}$ Exclui-se do escopo deste trabalho o sistema predial de suprimento de água quente que utiliza como fonte de energia para o aquecimento da água a energia solar, uma vez eu a adoção desta modalidade de aquecimento não é comum nos edifícios de múltiplos pavimentos localizados na cidade de São Paulo. Embora não se detalhe esta modalidade neste trabalho, os princípios do método elaborado aplicam-se perfeitamente à mesma, uma vez que a análise da produtividade não foca o sistema, e sim a execução de suas partes, comum aos demais sistemas descritos aqui.
} 
Em particular, embora o sistema de proteção e combate a incêndio utilize a água como insumo, o mesmo é classificado em função do serviço requerido pelo usuário, no caso, a segurança contra a ação do fogo, e não especificamente de acordo com o insumo utilizado, uma vez que a água não é o único insumo utilizado para tal.

O sistema de suprimento de água tem por função prover este insumo nos locais de uso, sejam eles reservatórios (ou aquecedores) ou os aparelhos sanitários (YWASHIMA, 2005). Assim, pode-se subdividi-lo em sistema predial de água fria e sistema predial de água quente, sendo que a configuração deste último é variável em função da fonte de aquecimento utilizada (gás, energia solar etc.).

Além destes sistemas, considerados básicos em uma edificação e de grande difusão no mercado e no meio acadêmico, a crescente preocupação com o uso racional da água nas edificações levou ao surgimento de sistemas relacionados ao reuso de águas servidas e ao aproveitamento das águas pluviais.

Embora se preconize e se enfatize a interação entre os sistemas prediais de uma edificação, para seu melhor entendimento, os mesmos serão apresentados e detalhados, na seqüência, separadamente.

\subsection{Sistema predial de suprimento de água fria}

\subsubsection{Definição}

O sistema predial de suprimento de água fria se constitui na extremidade do sistema público de abastecimento de água onde concretamente se estabelece o elo de ligação com o usuário final (NBR 5626, ABNT 1998). 
Segundo esta norma, este sistema é composto por tubos, reservatórios, peças de utilização, equipamentos e outros componentes, destinado a conduzir água fria da fonte de abastecimento aos pontos de utilização.

Sob a ótica do desempenho, o sistema predial de água fria deve prover, quando necessária ao uso, água de boa qualidade, em quantidade e temperatura controláveis pelo usuário, para sua adequada utilização (GONÇALVES, 2007).

\subsubsection{Requisitos de desempenho}

De acordo com a NBR 5626 (ABNT, 1998), os sistemas prediais de água fria devem ser projetados de modo que, durante a vida útil do edifício, atendam aos seguintes requisitos:

- $\quad$ preservar a potabilidade da água ${ }^{17}$;

- garantir o fornecimento de água de forma contínua, em quantidade adequada e com pressões e velocidades compatíveis com o perfeito funcionamento dos aparelhos sanitários, peças de utilização e demais componentes;

- promover economia de água e de energia;

- possibilitar manutenção fácil e econômica;

- evitar níveis de ruído inadequados à ocupação do ambiente;

- proporcionar conforto aos usuários prevendo peças de utilização adequadamente localizadas, de fácil operação, com vazões satisfatórias e atendendo as demais exigências dos usuários.

\footnotetext{
${ }^{17}$ Conjunto de valores máximos permissíveis às características de qualidade da água destinada ao consumo humano, conforme determina a Portaria no. 26 do Ministério da Saúde (NBR 5626, ABNT 1998).
} 
O sistema predial de suprimento de água fria deve atender as demandas relativas à vazão, pressão e a qualidade da água nos pontos de consumo (SANTOS, 2002).

\subsubsection{Classificação}

O sistema predial de suprimento de água fria é classificado em função das pressões e vazões disponíveis do sistema abastecimento (rede pública ou particular), assim como sua continuidade e confiabilidade do abastecimento. Assim, são identificadas duas modalidades de abastecimento (Sistema direto e Sistema indireto), sendo que em cada uma destas modalidades podem existir diversas configurações que visam garantir o desempenho satisfatório destes sistemas quanto a estes requisitos (Figura $3.2)$.

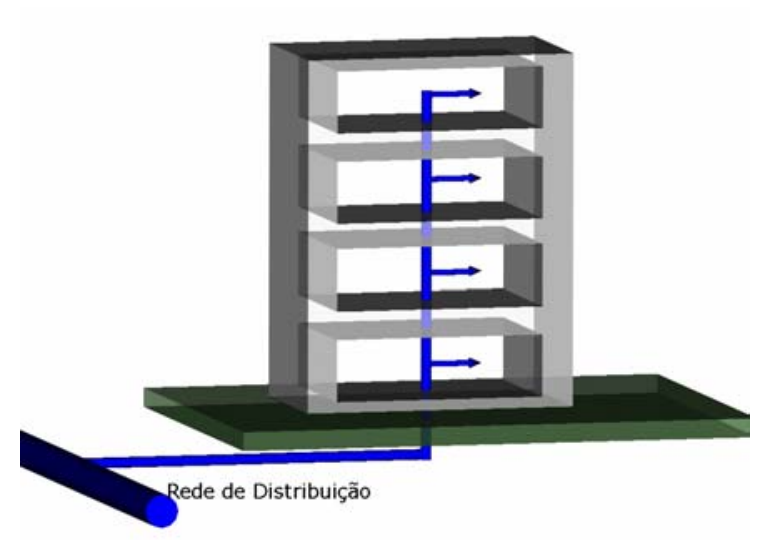

SD-S

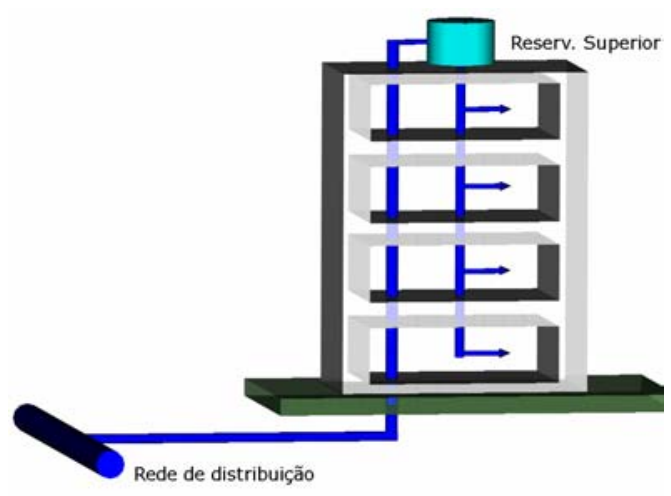

SI-G-RS

Figura 3.2 - Classificação do sistema predial de água fria em função do tipo de abastecimento: (a) Sistema direto; (b) sistema indireto (adaptado de ILHA; GONÇALVES, 1996) 


\subsubsection{Sistema de abastecimento direto}

O sistema direto é caracterizado pela ligação direta da rede pública de abastecimento aos pontos de utilização, ou seja, aos equipamentos sanitários, não havendo reservação intermediária da água.

Em função das condições de pressão e vazão da rede pública de abastecimento, o sistema direto pode ser provido de bombeamento ou não. Assim, quando a rede pública de abastecimento oferece condições de vazão, pressão e continuidade suficientes ao esperado desempenho do sistema, utiliza-se o sistema direto sem bombeamento (Figura 3.3a). Caso contrário, faz-se o uso de um sistema de bombeamento direto onde a água é recalcada diretamente aos equipamentos sanitários (Figura 3.3b) (ILHA; GONÇALVES, 1996).

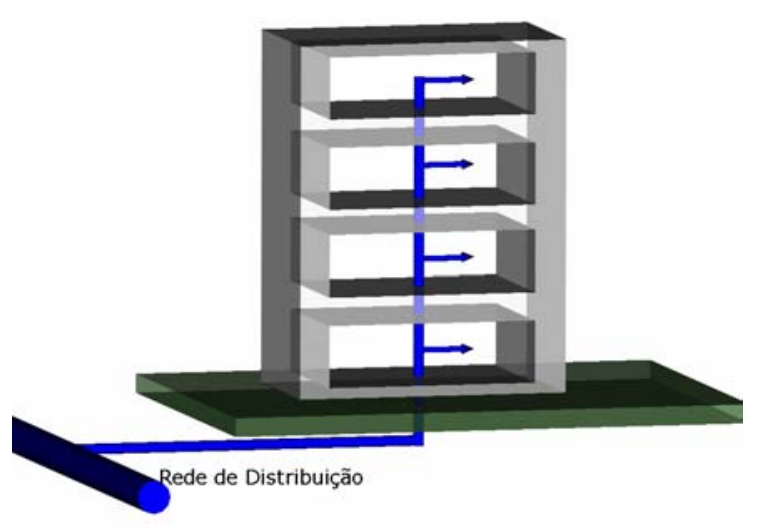

(a)

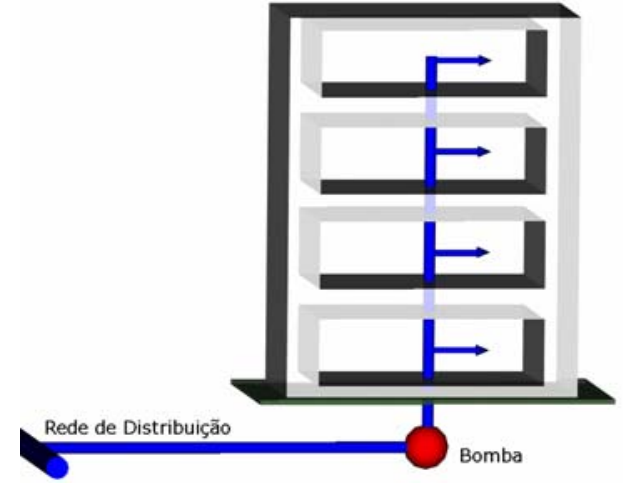

(b)

Figura 3.3 - Sistema de abastecimento direto: (a) sem bombeamento (SD-S); (b) com bombeamento (SD-B Booster) (adaptado de ILHA; GONÇALVES, 1996)

Embora este sistema seja aparentemente mais econômico, uma vez que dispensa o uso de reservatórios, a economia é muito pequena frente à exposição do usuário às 
deficiências do sistema de abastecimento da rede pública (BOTELHO; RIBEIRO JR, 1998).

Por outro lado, os autores enfatizam a necessidade da utilização de uma válvula de retenção para evitar a contaminação da rede pública devido a um eventual refluxo (retrossifonagem ${ }^{18}$ ou pressão negativa).

\subsubsection{Sistema de abastecimento indireto}

O sistema indireto é caracterizado pela reservação intermediária da água antes de a mesma chegar aos pontos de consumo. Com relação à pressurização, a alimentação do sistema indireto pode ser por gravidade ou hidropneumático.

\section{Sistema indireto por gravidade}

Neste tipo de sistema, a rede de distribuição interna é alimentada por um reservatório elevado, podendo este ser alimentado diretamente pela rede pública de abastecimento, com ou sem bombeamento, ou por um reservatório inferior com bombeamento, configurando-se em 3 tipos de sistemas indiretos por gravidade: sistema indireto com uso de reservatório superior (Figura 3.4a), sistema indireto com bombeamento da água diretamente da rede pública de abastecimento ao reservatório superior (Figura 3.4b) e sistema indireto contendo reservatórios inferior e superior, com um sistema de bombeamento entre os mesmos (Figura 3.4c).

\footnotetext{
${ }^{18}$ Retrossifonagem: refluxo da água usada, proveniente de um reservatório, aparelho sanitário ou de qualquer outro recipiente, para o interior de uma tubulação, devido a sua pressão ser inferior à atmosférica (NBR 5626, ABNT 1998).
} 


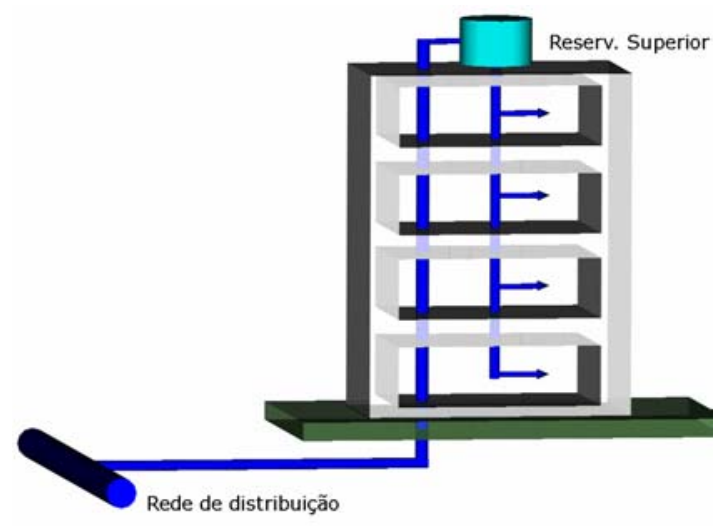

(a)

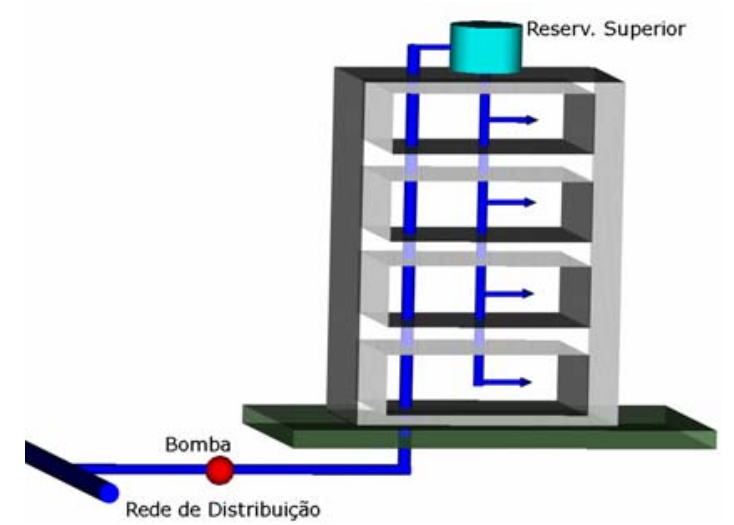

(b)

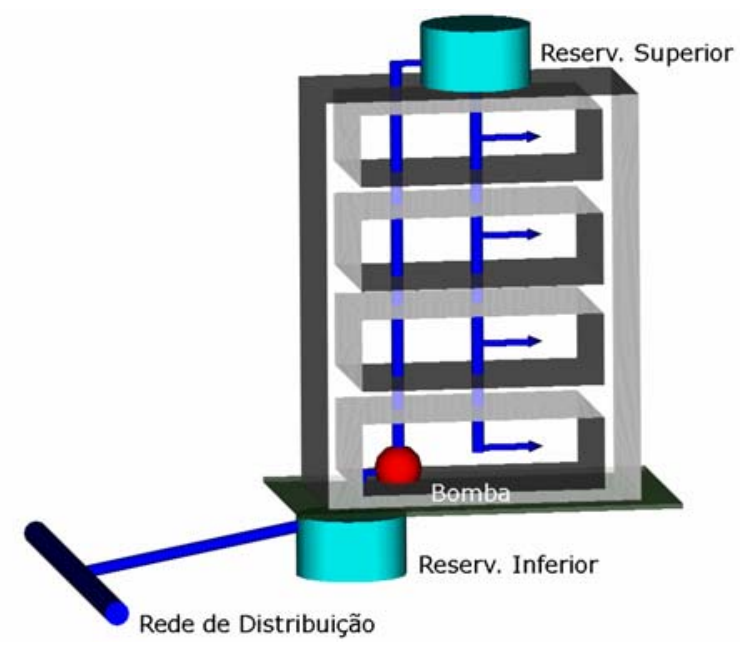

(c)

Figura 3.4 - Sistema indireto: (a) com uso de reservatório superior (SI-G-RS); (b) com bombeamento da água diretamente da rede pública de abastecimento ao reservatório superior (SI-G-RS/B); (c) contendo reservatórios inferior e superior e dispositivo de bombeamento da água entre os mesmos (SI-G-RS/RI)

(adaptado de ILHA; GONÇALVES, 1996)

A necessidade ou não de bombeamento está condicionada à presença de pressão do sistema de abastecimento suficiente para elevar a água ao reservatório superior. 


\section{Sistema indireto Hidropneumático}

Nesta modalidade, o escoamento da água na rede de distribuição é pressurizado através de um tanque de pressão contendo ar e água, podendo ser sem bombeamento (Figura 3.5a), com bombeamento (Figura $3.5 \mathrm{~b}$ ) ou ainda com bombeamento e reservatório inferior, sendo este último também denominado sistema hidropneumático (Figura 3.5c).

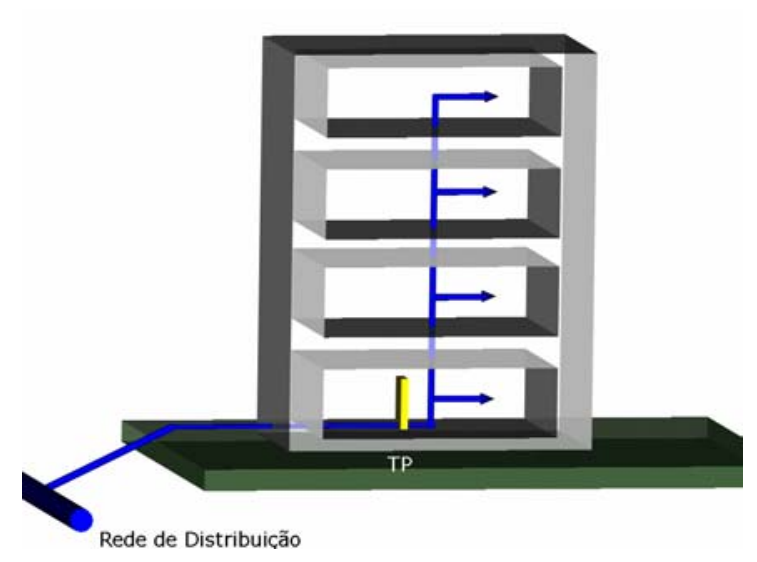

(a)

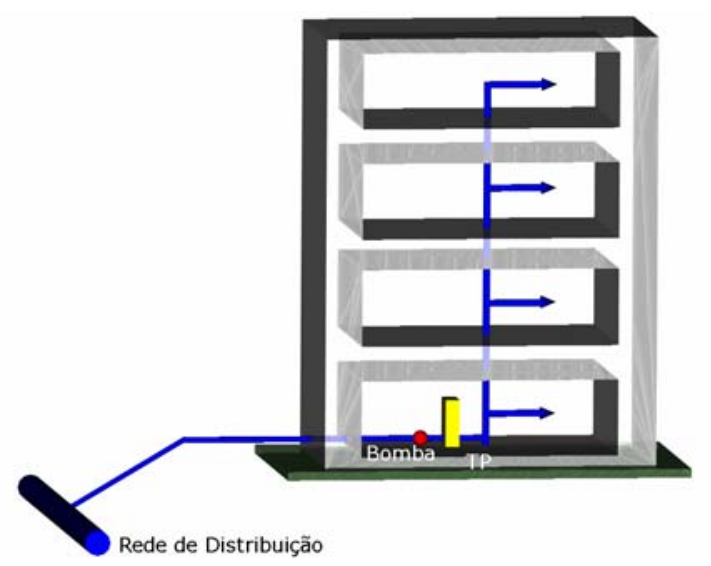

(b)

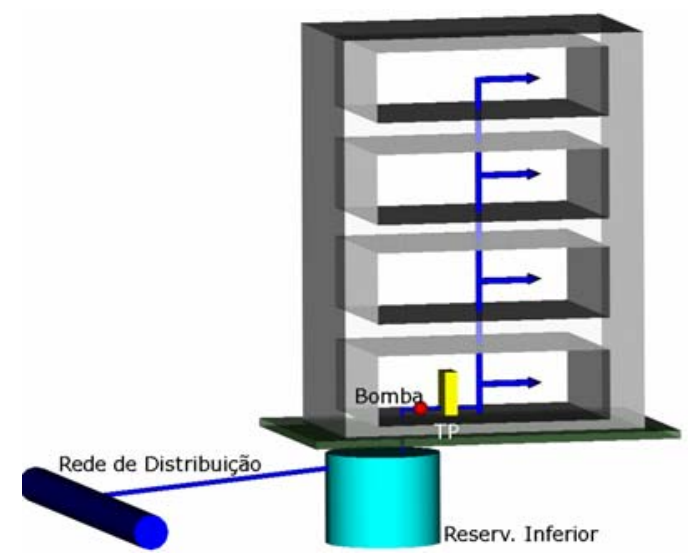

(c)

Figura 3.5 - Sistema indireto hidropneumático: (a) sem bombeamento (SI-H); (b) com bombeamento (SI-H-B); (c) com bombeamento e reservatório inferior (SI-H-B/RI) (adaptado de ILHA; GONÇALVES, 1996) 


\section{Sistema Misto}

O sistema misto caracteriza-se pelo uso conjugado do sistema indireto com o direto. Este sistema é muito comum em edificações unifamiliares térreas. A opção por este sistema proporciona não somente a redução do volume de reservação, como também, a redução do consumo de água do reservatório superior, muito útil em situações de baixa pressão na rede pública de abastecimento (BOTELHO; RIBEIRO JR., 1998).

\subsubsection{Escolha do tipo de sistema}

A adoção da tipologia do sistema predial de água fria está relacionada às condições oferecidas pela fonte de abastecimento no que diz respeito à continuidade e confiabilidade de fornecimento da água, vazões e pressões disponíveis no sistema de abastecimento.

Segundo Ilha; Gonçalves (1996), se o sistema de abastecimento suprir este insumo de forma contínua e confiável, pode-se adotar tanto o sistema direto quanto o indireto. A sua escolha, portanto, reside nas condições de pressão e vazão disponíveis em relação às necessárias para o desempenho satisfatório do sistema predial de água fria.

Mais objetivamente, segundo estes autores, a escolha resulta da comparação entre a vazão do sistema de abastecimento (QA) e a vazão demandada (QD) e da comparação entre a pressão disponível do sistema de abastecimento (PD, A) e a pressão nominal de demanda (PN, D).

Levando em consideração estes aspectos, Gonçalves (2007) sintetizou em uma tabela o raciocínio a ser seguido na escolha do sistema predial de água fria (Tabela 3.2). 
Tabela 3.2 - Parâmetros para escolha do tipo de sistema predial de água fria GONÇALVES (2007)

\begin{tabular}{|l|l|l|l|}
\hline \multicolumn{2}{|c|}{ Condições } & Tipo de sistema \\
\hline $\begin{array}{l}\text { Continuidade de } \\
\text { fornecimento }\end{array}$ & $\mathbf{Q}_{\mathbf{A}} \geq \mathbf{Q}_{\mathbf{D}}$ & $\mathbf{P}_{\mathbf{D}, \mathbf{A}} \geq \mathbf{P}_{\mathbf{N}, \mathbf{D}}$ & \\
\hline Sim $\left(^{*}\right)$ & $\operatorname{Sim}$ & Sim & Sistema Direto sem bombeamento \\
\cline { 2 - 4 } & Sim & Não & Sistema Direto com bombeamento \\
\cline { 2 - 4 } & Não & Sim & $\begin{array}{l}\text { Sistema Indireto, por gravidade e com reservatório } \\
\text { superior }\end{array}$ \\
\cline { 2 - 4 } & Não & Não & $\begin{array}{l}\text { Sistema Indireto, por gravidade e com reservatórios } \\
\text { superior e inferior; sistema indireto, hidropneumático }\end{array}$ \\
\hline \multirow{2}{*}{ Não } & Sim & Sim & $\begin{array}{l}\text { Sistema indireto, por gravidade e com reservatório } \\
\text { superior }\end{array}$ \\
\cline { 2 - 4 } & Sim & Não & $\begin{array}{l}\text { Sistema Indireto, por gravidade e com reservatórios } \\
\text { superior e inferior; sistema indireto, hidropneumático }\end{array}$ \\
\cline { 2 - 4 } & Não & Sim & $\begin{array}{l}\text { Sistema Indireto, por gravidade e com reservatório } \\
\text { superior }\end{array}$ \\
\cline { 2 - 4 } & Não & Não & $\begin{array}{l}\text { Sistema Indireto, por gravidade e com reservatórios } \\
\text { superior e inferior; sistema indireto, hidropneumático }\end{array}$ \\
\hline
\end{tabular}

$\left(^{*}\right)$ Reservação para atender as vazões de pico (compensação)

$\left.{ }^{* *}\right)$ Reservação para atender as vazões de pico e o período de falta de fornecimento pelo sistema de abastecimento (compensação + reservação)

\subsubsection{Partes constituintes}

O sistema predial de água fria pode ser dividido nos subsistemas de alimentação, reservação/pressurização e distribuição interna (Tabela 3.3).

Tabela 3.3 - Elementos do sistema predial de suprimento de água fria

\begin{tabular}{|l|l|}
\hline Subsistemas & Elementos \\
\hline Alimentação & ramal predial \\
& cavalete, hidrômetro \\
& alimentador predial \\
\hline Reservação/pressurização & Reservatório inferior \\
& Estação elevatória \\
& Reservatório superior \\
\hline Distribuição interna & Barrilete \\
& Coluna de distribuição \\
& Ramal \\
& Sub-ramal \\
\hline
\end{tabular}




\subsubsection{Alimentação}

O subsistema de alimentação compreende o trecho que liga a fonte de abastecimento até o ponto de reservação, seja este o reservatório inferior ou superior, ou até mesmo a rede predial de distribuição, dependendo do tipo de sistema predial adotado: direto ou indireto (BOTELHO; RIBEIRO JR., 1998).

É composto pelo ramal predial (ou ramal externo); cavalete, no qual se instala o aparelho medidor de consumo de água (hidrômetro) e alimentador predial (ou ramal interno) (Figura 3.6).

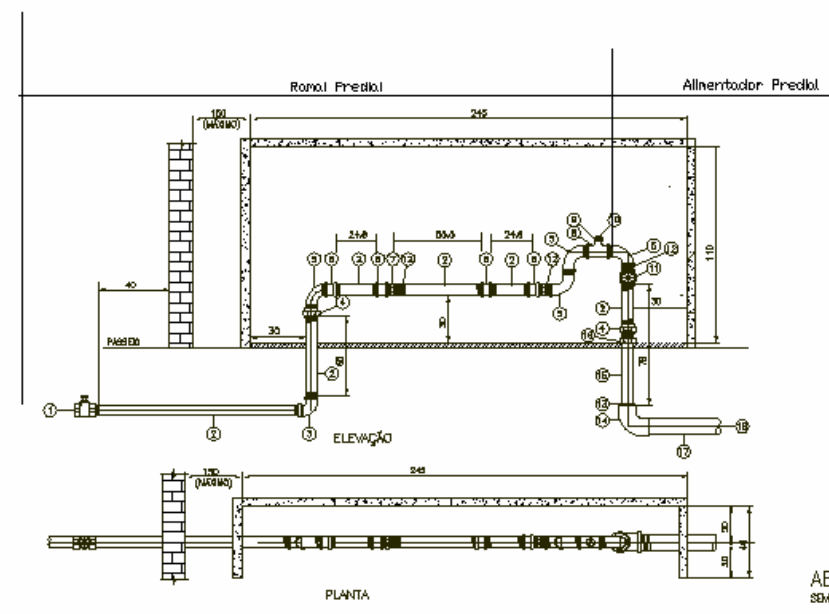

Figura 3.6 - Ramais externo e interno e seus componentes (TESIS, 2003)

\section{Ramal predial (ramal externo)}

Segundo a NBR 5626 (ABNT, 1998), o ramal predial é a "tubulação compreendida entre a rede pública de abastecimento de água e a extremidade a montante do alimentador predial ou da rede predial de distribuição" e deve ser executado pela concessionária pública. 
O ramal predial envolve alguns componentes, tais como: o cavalete e o respectivo dispositivo de medição de consumo de água e registro de fecho ou passeio ${ }^{19}$.

\section{Cavalete/hidrômetro}

O cavalete é definido pela NBR 10925 (ABNT, 1989) como sendo o "conjunto de tubos, conexões e registros do ramal predial, destinado a instalação do hidrômetro e respectivos tubetes, ou limitador de consumo, em posição afastada do piso" e deve ser projetado obedecendo as exigências estabelecidas pela concessionária.

Pode ser executado em diversos materiais, sempre obedecendo a normas específicas: PVC rígido (NBR 10925; ABNT, 1989), aço galvanizado (NBR 14122; ABNT, 1998) ou em polipropileno (NBR 11304; ABNT, 1990).

\section{Alimentador predial (ramal interno)}

Trata-se do trecho compreendido entre o final do ramal predial (cavalete) até a saída de água junto ao reservatório inferior ou superior, dependendo do tipo de sistema adotado, podendo ser enterrado, aparente ou embutido (BOTELHO; RIBEIRO JR, 1998).

Segundo estes autores, o alimentador predial é composto por torneira de bóia na extremidade final, com registro de fechamento localizado fora do reservatório, com a finalidade de facilitar a sua operação e manutenção.

\footnotetext{
${ }^{19}$ Componente instalado na tubulação e destinado a interromper a passagem da água; geralmente, empregam-se registros de gaveta ou registros de esfera e, em ambos os casos, o registro deve apresentar seção de passagem da água com área igual à da seção interna da tubulação onde está instalado (NBR 5626, ABNT 1998). Geralmente as concessionárias prevêem este registro na calçada externa de modo que se possa interromper o abastecimento de água à edificação (BOTELHO; RIBEIRO JR., 1998)
} 
Deve-se prever também um dispositivo de proteção contra o refluxo de água (retrossifonagem). Para o caso do sistema de abastecimento direto, utiliza-se uma válvula de retenção; no caso do abastecimento indireto com a utilização de reservatório (inferior ou superior), a proteção é feita por separação atmosférica na entrada de água do reservatório e, no caso do sistema misto, as duas medidas devem ser previstas e adotadas (BOTELHO; RIBEIRO JR, 1998).

\subsubsection{Reservatórios}

A previsão de reservação ou não de água, conforme apresentado no item 3.3.3, está relacionada às condições de disponibilidade e confiabilidade, vazão e pressão oferecidas pela fonte de abastecimento. O sistema que utiliza reservatórios, sejam eles inferior ou superior, denomina-se sistema indireto.

\section{Reservatórios (inferior e superior)}

Em termos de padrão de potabilidade da água, os reservatórios são considerados um ponto crítico do sistema predial de água fria, devendo haver uma atenção especial no que diz respeito à escolha dos materiais, forma e dimensões, modo de instalação e operação, assim como o sistema de impermeabilização (NBR 5626, ABNT 1998).

Podem ser construídos de concreto armado (figuras 3.7 e 3.8), alvenaria, fibrocimento, PVC, polietileno etc., desde que respeitada as condições prescritas nas respectivas normas da $\mathrm{ABNT}^{20}$.

\footnotetext{
${ }^{20}$ Concreto armado: NBR 6118 (ABNT, 2003); fibrocimento: NBR 5649 (ABNT, 2006)
} 


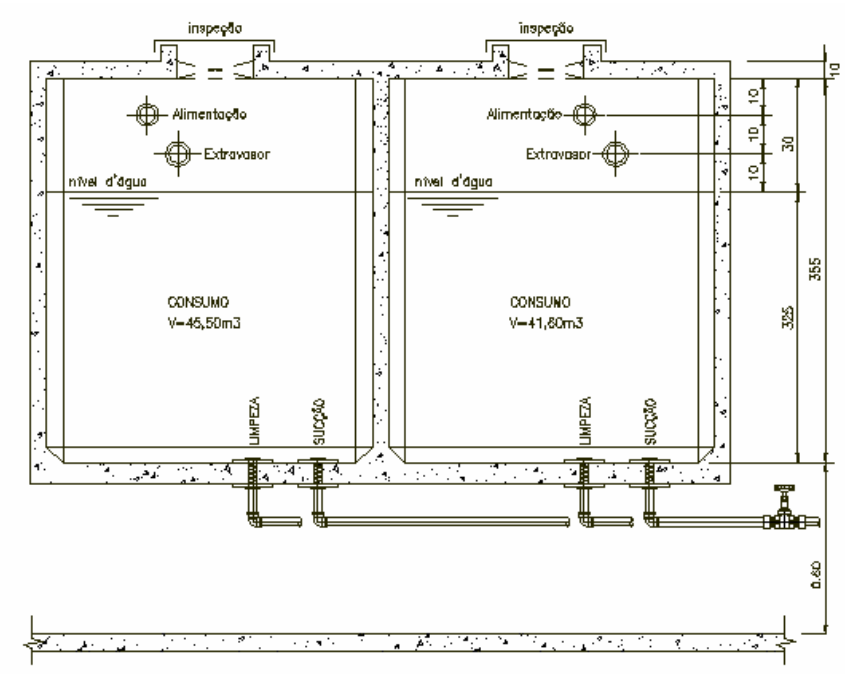

WOUME CONSUNO $=87,10 \mathrm{~m} \mathrm{~m}^{3}$

CORTE ESQUEMATICO DO RESERVATORIO INFERIOR

Figura 3.7 - Corte: reservatório inferior (TESIS, 2003)

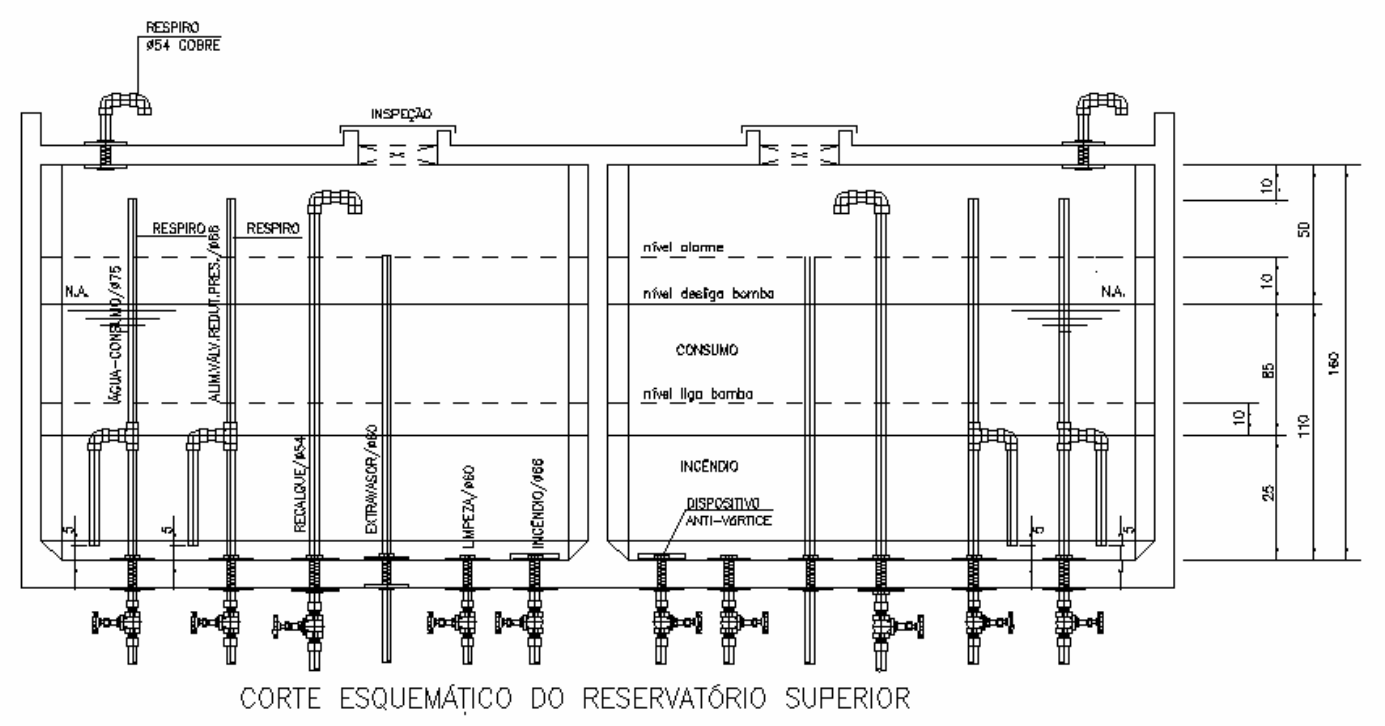

Figura 3.8 - Reservatório superior (TESIS, 2003)

\section{Estação elevatória}

A estação elevatória consiste no sistema destinado a elevar a pressão da água em uma instalação predial de água fria quando a pressão disponível na fonte de 
abastecimento é insuficiente para abastecimento do tipo direto, ou para suprimento do reservatório elevado no caso de abastecimento do tipo indireto. Inclui também o caso onde um equipamento é usado para elevar a pressão em pontos de utilização localizados (NBR 5626, ABNT 1998).

As instalações elevatórias devem possuir no mínimo duas unidades de elevação de pressão, independentes, com vistas a garantir o abastecimento de água no caso de falha de uma das unidades (Figura 3.9).

Nas instalações elevatórias por recalque de água, recomenda-se a utilização de comando liga/desliga automático, condicionado ao nível de água nos reservatórios. Neste caso, este comando deve permitir também o acionamento manual para operações de manutenção.

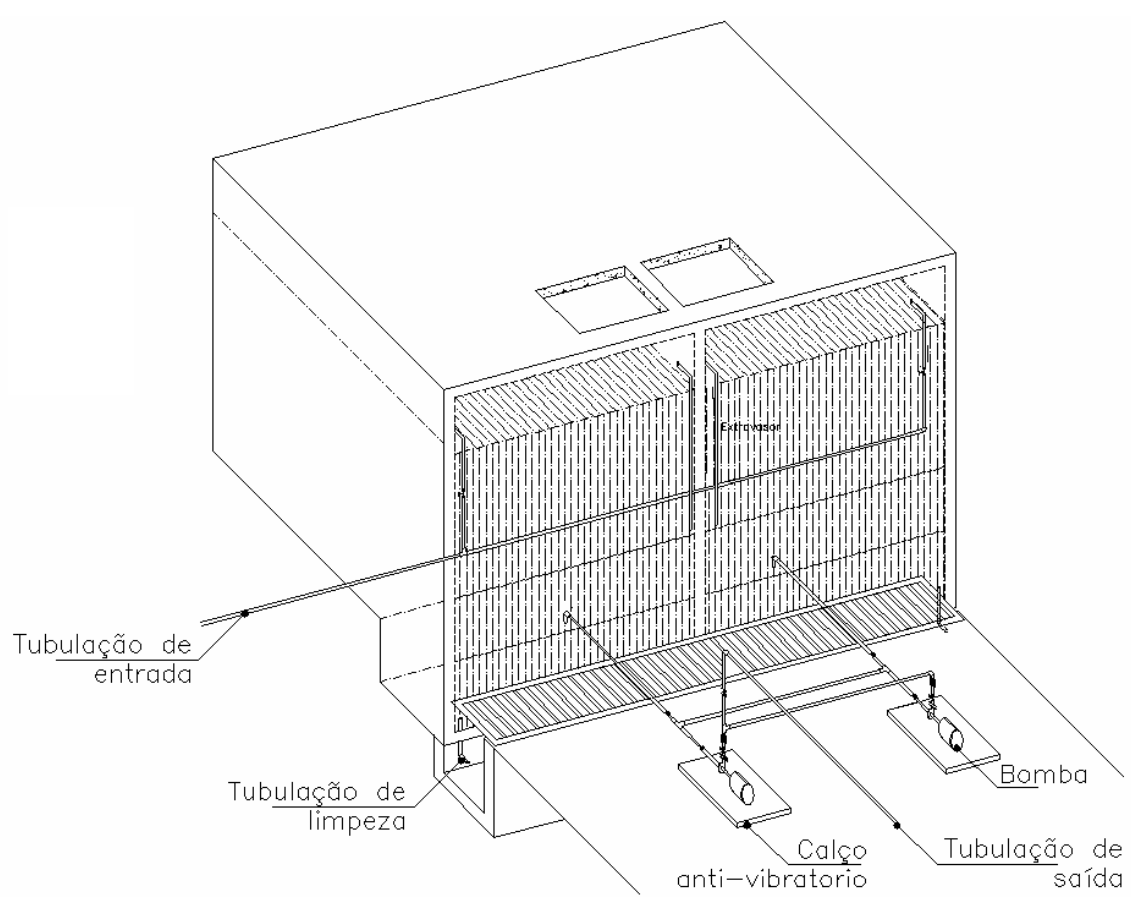

Figura 3.9 - Reservatório inferior e as instalações elevatórias ${ }^{21}$

\footnotetext{
${ }^{21}$ Notas de aulas da disciplina Sistemas Prediais Hidráulicos e Sanitários do Curso de Engenharia Civil da UFSCar. Disponível em http://www.deciv.ufscar.br/ simar/sphs1.htm.
} 


\subsubsection{Distribuição interna}

A distribuição interna consiste no conjunto de tubulações formado por barriletes, colunas de distribuição, ramais e sub-ramais ou de alguns destes elementos, destinados a levar água aos pontos de utilização (NBR 5626, ABNT 1998).

\section{Barrilete}

O barrilete ou colar de distribuição é um conjunto de tubulação originária no reservatório, da qual se derivam as colunas de distribuição quando o tipo de abastecimento é indireto. No caso de tipo de abastecimento direto, pode ser considerado como a tubulação diretamente ligada ao ramal predial ou diretamente ligada à fonte de abastecimento particular (NBR 5626, ABNT 1998). Em um sistema de abastecimento indireto, segundo Botelho; Ribeiro JR. (1998), o uso de barrilete dispensa a execução de uma série de furos no reservatório que, além de antieconômico, uma vez que haveria a necessidade da utilização de vários registros, poderia comprometer o sistema de impermeabilização. Uma outra questão está relacionada ao fato de que, com a adoção do barrilete, se tem acesso às duas seções do reservatório, o que não acontece se a coluna de distribuição fosse ligada diretamente a ele.

O barrilete pode ser de dois tipos: o concentrado (unificado ou central) e o ramificado (Figura 3.10). O tipo concentrado permite que os registros de operação se localizem em uma área restrita, facilitando o controle e segurança do sistema (BOTELHO; RIBEIRO JR., 1998). 


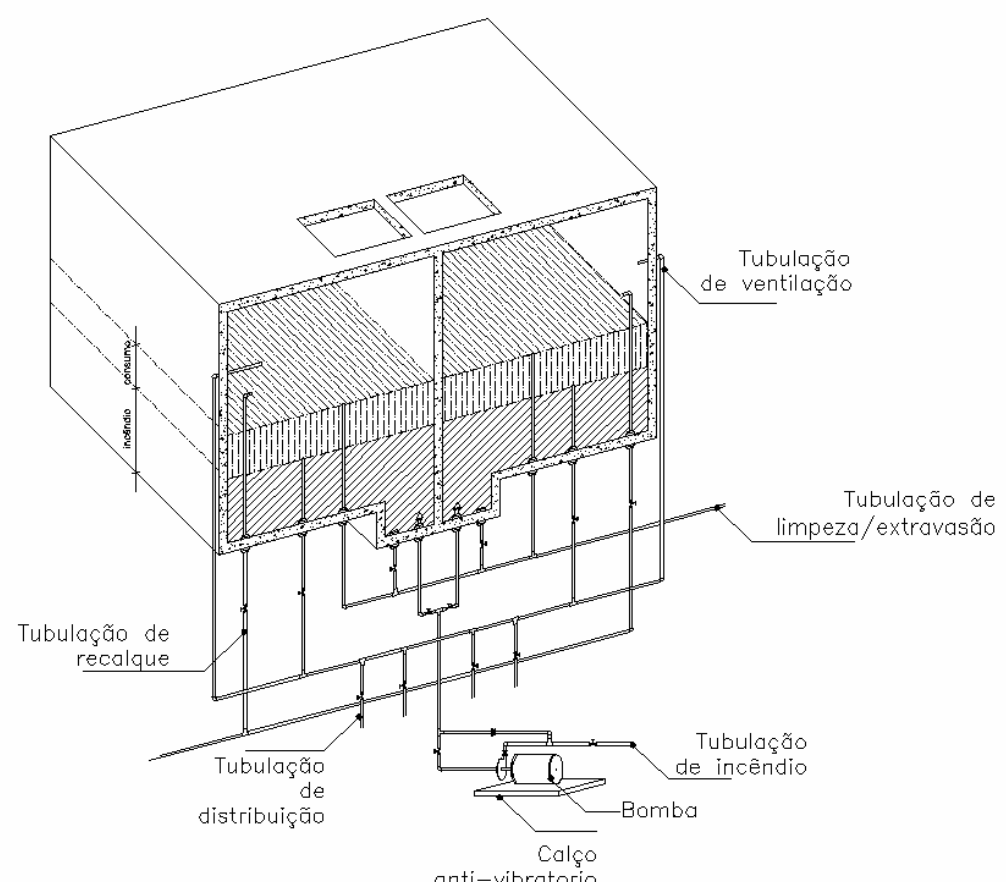

(a)

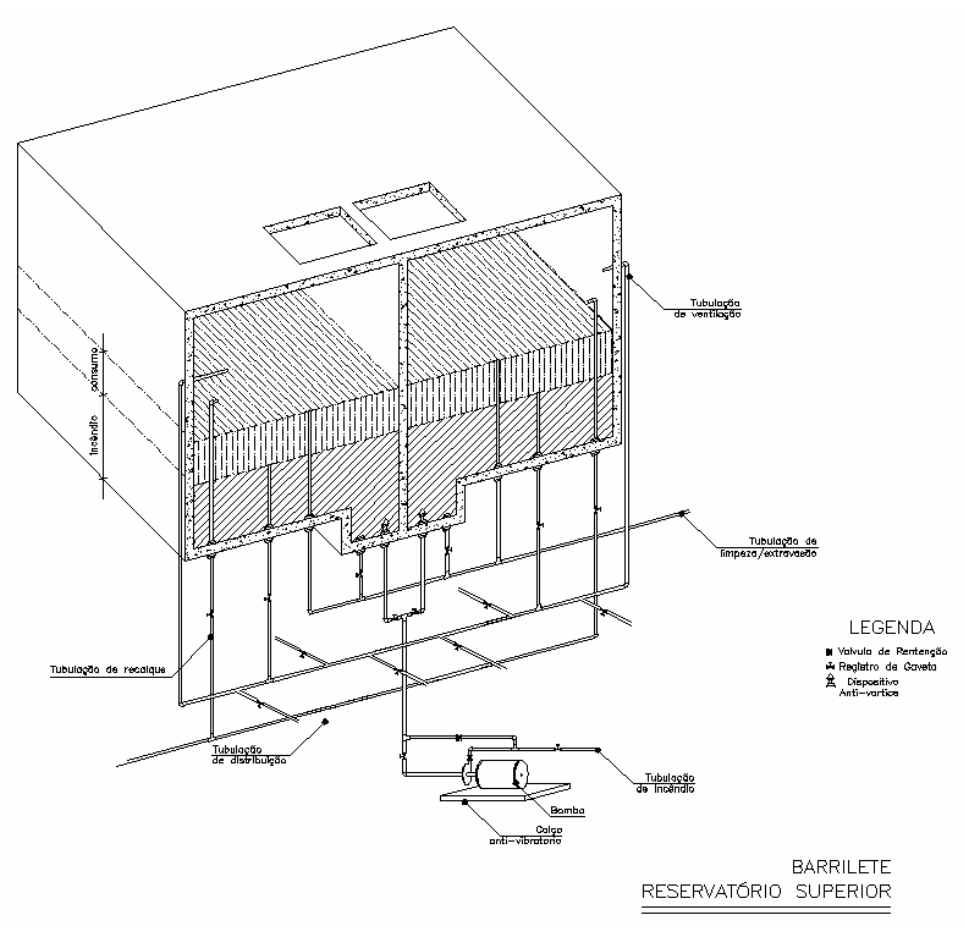

(b)

Figura 3.10 - Tipos de barrilete: a) concentrado b) ramificado ${ }^{22}$

\footnotetext{
${ }^{22}$ Notas de aulas da disciplina Sistemas Prediais Hidráulicos e Sanitários do Curso de Engenharia Civil da UFSCar. Disponível em http://www.deciv.ufscar.br/ simar/sphs1.htm.
} 


\section{Coluna de distribuição}

A coluna de distribuição consiste na tubulação derivada do barrilete destinada a alimentar ramais (NBR 5626, ABNT 1998). Um cuidado adicional deve ser tomado caso a coluna de distribuição alimente ramais, cujos aparelhos sanitários estejam sujeitos a retrossifonagem, como é o caso das bacias sanitárias providas de válvula de descarga.

Nestes casos, a NBR recomenda que se destine uma coluna de distribuição, barrilete e reservatório exclusivos para alimentação destes aparelhos sanitários. No caso da alimentação conjunta com os outros aparelhos sanitários, deve-se adotar um dispositivo quebrador de vácuo no sub-ramal que alimenta os aparelhos sujeitos à retrossifonagem ou uma coluna de ventilação ligada à coluna de distribuição, com diâmetro igual ou superior à mesma, ligada a jusante do registro de passagem existente, com comprimento suficiente que garanta que a extremidade desta coluna de ventilação fique acima do nível máximo de água admitido do reservatório superior.

\section{Ramais e sub-ramais}

O ramal é definido como sendo a tubulação derivada da coluna de distribuição e destinada a alimentar os sub-ramais que, por sua vez, ligam o ramal ao ponto de utilização (NBR 5626, ABNT 1998) (Figura 3.11). 

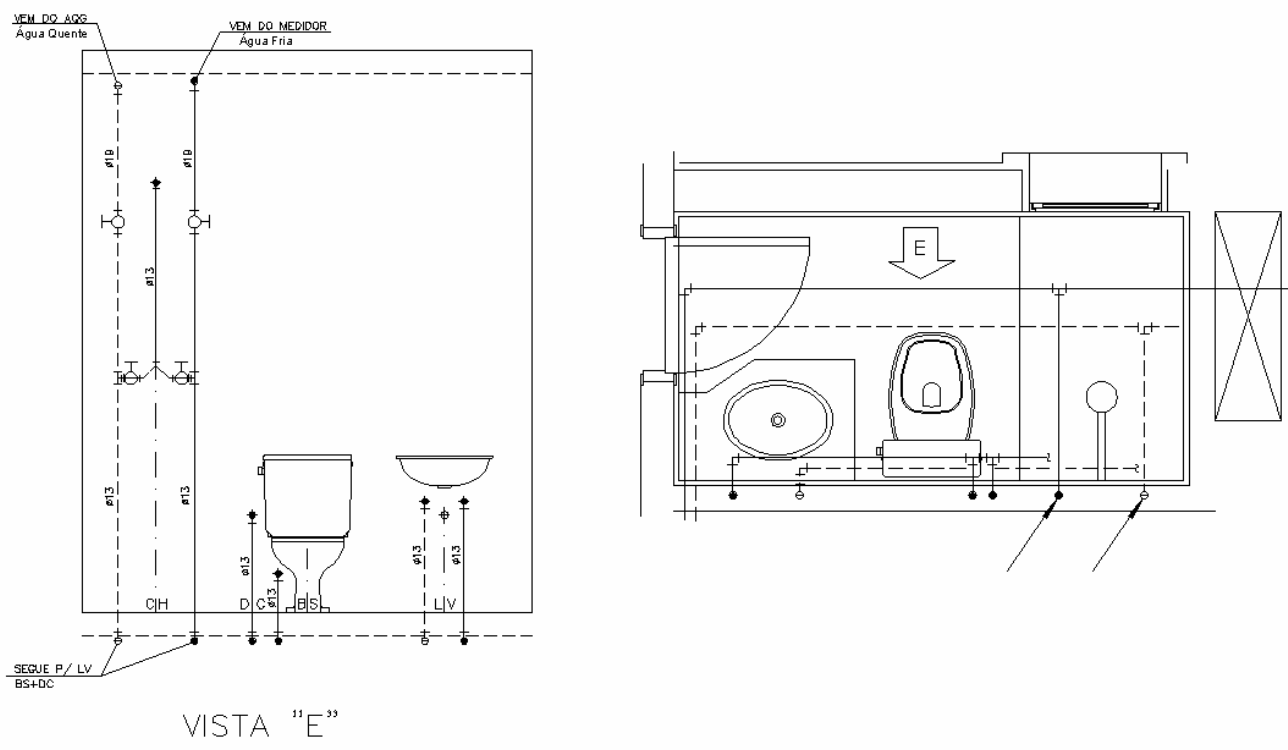

Figura 3.11 - Ramal e sub-ramais (GONÇALVES, 2007)

\subsection{Sistema predial de suprimento de água quente}

\subsubsection{Definição}

O sistema predial de suprimento de água quente é definido como sendo um conjunto de equipamentos e acessórios destinados à produção e condução de água quente aos pontos de consumo em uma unidade habitacional.

As exigências técnicas mínimas quanto à higiene, à segurança, à economia e ao conforto dos usuários, assim como aspectos de projetos e execução são determinados pela NBR 7198 (ABNT, 1993). 


\subsubsection{Requisitos de desempenho}

Segundo esta norma, o sistema predial de suprimento de água quente deve ser projetado de modo a:

(a) garantir o fornecimento de água quente de forma contínua, em quantidade suficiente e temperatura controlável aos usuários e com as pressões e velocidades compatíveis com o perfeito funcionamento dos aparelhos sanitários e das tubulações;

(b) preservar a potabilidade da água;

(c) proporcionar o nível de conforto adequado aos usuários.

\subsubsection{Classificação}

A classificação do sistema predial de suprimento de água quente está relacionada à forma de produção de água quente, fonte de energia utilizada no aquecimento da água e na necessidade de acumulação ou não da água aquecida.

Cada configuração requer equipamentos distintos e concepções diferentes de projeto no que diz respeito à necessidade ou não de distribuição da água quente por tubulações, tipo de material empregado nas tubulações e tipo de equipamentos destinados ao aquecimento da água. 


\subsubsection{Quanto à abrangência de pontos de consumo abastecidos simultaneamente}

Quanto a este critério, o sistema de aquecimento pode ser classificado em sistema de aquecimento individual e sistema de aquecimento central, sendo este último classificado ainda em privado ou coletivo.

O sistema de aquecimento individual caracteriza-se pelo aquecimento junto ao ponto de consumo de água quente, além do fato de a alimentação do aquecedor ser feita através da própria rede que abastece os outros pontos de consumo de água fria. Como o aquecimento é feito junto ao ponto de consumo, não há condução de água quente nas tubulações, não exigindo tubulações específicas para tal. São exemplos desta modalidade de aquecimento: o chuveiro e as torneiras para pias da cozinha.

O sistema central caracteriza-se pela alimentação de mais de um ponto de consumo simultaneamente. O central privado destina-se ao fornecimento de água quente em vários pontos de consumo de uma única unidade habitacional (apartamento) enquanto que o central coletivo abastece vários pontos de consumo em mais de uma unidade habitacional simultaneamente. São exemplos desta modalidade de aquecimento os aquecedores de passagem (central privado) e caldeiras (central coletivo).

\subsubsection{Quanto à fonte de energia para o aquecimento}

Várias são as fontes de energia utilizadas para o aquecimento da água nas edificações, tais como: a energia elétrica, gás combustível, óleo combustível além da energia solar.

No caso do sistema de aquecimento individual, a fonte energética mais utilizada é a elétrica. Já no sistema central privado recorre-se comumente ao gás como fonte de energia, mas também é comum a utilização de gás combustível para tal. Já no sistema 
central coletivo pode-se utilizar o gás combustível, a eletricidade ou o óleo combustível como fonte de energia, havendo, inclusive, a possibilidade de se prever a alternância entre mais de uma fonte de energia.

\subsubsection{Quanto à acumulação de água quente}

A água pode ser aquecida e reservada para posterior utilização ou aquecida no instante de sua utilização. No primeiro caso, utilizam-se aquecedores com acumulação e, no segundo, aquecedores de passagem. Os aquecedores com acumulação são utilizados nos sistemas centrais de aquecimento, privado ou coletivo, enquanto que os aquecedores de passagem são utilizados no sistema central privado.

\subsubsection{Sistemas integrados de aquecimento}

Atualmente há uma variedade de tipos de aquecedores de água no mercado, cada qual com suas vantagens e desvantagens. Por exemplo, os aquecedores de passagem são de fácil instalação e são de dimensões reduzidas quando, comparados, por exemplo, aos aquecedores de acumulação, que possuem maiores dimensões (CARVALHO JUNIOR, 2007).

Assim, segundo este autor, potencializando as vantagens de várias alternativas existentes no mercado é comum encontrar-se atualmente um sistema integrado que utiliza aquecedores de passagem projetados para aquecer a água e reservatórios de acumulação para reservar a água aquecida. 


\subsubsection{Partes constituintes}

O sistema predial de suprimento de água quente pode ser dividido em dois subsistemas: o de produção e o de distribuição de água quente.

O subsistema de produção de água quente caracteriza-se pelo tipo de aquecimento adotado e já descrito no item anterior. No que diz respeito ao subsistema de distribuição, como o próprio nome diz, este é encarregado da distribuição de água quente até os pontos de consumo e, logicamente, existe apenas no sistema predial central.

Este subsistema é composto pelos seguintes elementos, dependendo do tipo de aquecimento central adotado:

(a) privado: ramal de distribuição, cuja função é conduzir a água quente do subsistema de produção até os ambientes providos de pontos de consumo de água quente; ramais e sub-ramais, cuja função é alimentar os pontos de consumo de água quente, ou seja, fazem a ligação entre o ramal de distribuição e os pontos de consumo;

(b) coletivo: além de ser subdividido nos elementos listados para o central privado, possui também as prumadas, cuja função é alimentar os pavimentos ou apartamentos de água quente, uma vez que, a produção de água quente é centralizada e ocorre fora dos apartamentos, geralmente no subsolo do edifício.

Além destes elementos, estes sistemas podem ser providos de uma tubulação de retorno que, segundo a NBR 7198 (ABNT, 1993) destina-se à condução da água quente da tubulação de volta ao reservatório de água quente ou aquecedor, permitindo a sua circulação de modo que se tenha a água na temperatura exigida no ponto de consumo no momento do seu uso. 
Finalmente, destaca-se que, em função da dilatação térmica linear da tubulação condutora de água quente, deve-se calcular e prever juntas de expansão (ou liras de expansão) para absorção desta dilatação nos ramais de distribuição e tubulação de retorno, além das prumadas de água quente, caso haja a previsão de um sistema de aquecimento central coletivo.

\subsection{Sistema predial de suprimento de gás}

\subsubsection{Definição}

O sistema predial de suprimento de gás combustível em residências tem por objetivo a alimentação dos aparelhos, tais como fogões domésticos e aquecedores de água, e, eventualmente, algum outro aparelho que porventura o necessite (AMORIM, 2006).

\subsubsection{Requisitos}

Os requisitos gerais e específicos para o sistema predial de suprimento de gás em edificações são dispostos na NBR 13932 (ABNT, 1997) e NBR 13933 (ABNT, 1997), dentre os quais, destacam-se:

(a) tanto o dimensionamento da tubulação de gás quanto a especificação dos reguladores de pressão devem ser feitos de tal forma a manter a pressão nos pontos de consumo (ou utilização) tão próxima quanto possível da pressão nominal estabelecida pelas normas brasileiras para os respectivos aparelhos de utilização de gás ou, na falta destes, da pressão nominal informada pelo fabricante; 
(b) o mesmo se aplica de modo a garantir a vazão necessária para suprir a instalação, levando-se em conta a perda de carga máxima admitida para garantir um perfeito funcionamento dos aparelhos de utilização de gás.

Além destes requisitos, as normas trazem claramente as especificações necessárias no sentido de se evitar o vazamento de gás nas edificações, acarretando riscos à segurança da habitação e dos usuários.

\subsubsection{Tipo de gás}

Nas edificações podem ser utilizados o gás liquefeito de petróleo (GLP) e o gás natural (GN). O GLP é composto, em sua maior parte, por produtos constituídos de hidrocarbonetos com três ou quatro átomos de carbono, tais como o Propano $\left(\mathrm{C}_{3} \mathrm{H}_{8}\right)$ e Butano $\left(\mathrm{C}_{4} \mathrm{H}_{10}\right)$ e, em mínimas porcentagens, de Etano, Metano e frações mais pesadas do petróleo, como o Pentano $\left(\mathrm{C}_{5} \mathrm{H}_{12}\right)$, além de produtos insaturados como o Propeno e o Buteno. Já o gás natural é constituído por hidrocarbonetos combustíveis gasosos, essencialmente o metano, cuja produção pode ser associada ou não à produção de petróleo (AMORIM, 2001).

Além destes, o autor cita ainda que se pode utilizar gás de nafta, obtido em operação de craqueamento catalítico da nafta, um subproduto do petróleo e que destila entre 100 e $250^{\circ} \mathrm{C}$. No entanto, este tipo de gás vem sendo substituído pelo gás natural. Na Tabela 3.4, a seguir, são apresentadas as principais propriedades destes gases. 
Tabela 3.4 - Propriedades do GNP, GLP e gás de nafta (AMORIM, 2006)

\begin{tabular}{|l|c|c|c|}
\hline \multirow{2}{*}{ Características } & \multicolumn{3}{|c|}{ Tipo de gás } \\
\cline { 2 - 4 } & GLP & GN & Gás de nafta \\
\hline Densidade (relativa ao ar) & 1,835 & 0,60 & 0,57 \\
\hline Poder calorífico $\left(\mathrm{Kcal} / \mathrm{m}^{3}\right)$ & 24.000 & 9.200 a 9400 & 4750 \\
\hline
\end{tabular}

Em função destas propriedades, podem-se eleger algumas vantagens de um gás em relação ao outro, conforme ilustrado na Tabela 3.5.

Tabela 3.5 - Vantagens na utilização da cada gás (AMORIM, 2001)

\begin{tabular}{|c|c|}
\hline Gás Natural & GLP \\
\hline $\begin{array}{l}\text { - elimina o manuseio de recipientes } \\
\text { pressurizados, portanto aumenta a } \\
\text { segurança; } \\
\text { - existe ganho de espaço físico pela } \\
\text { eliminação de recipientes; } \\
\text { - devido a sua densidade ser menor que o } \\
\text { ar atmosférico }(0,57) \text {, ele se dilui } \\
\text { rapidamente na atmosfera; } \\
\text { não é tóxico. }\end{array}$ & $\begin{array}{l}\text { - devido a sua distribuição aos pontos de } \\
\text { consumo dar-se a pressões altas, as } \\
\text { tubulações possuem menor diâmetro; } \\
\text { - } \quad \text { o poder calorífico é superior ao do gás de } \\
\text { rede pública; } \\
\text { - não dá origem a fumaça e a fuligem; }\end{array}$ \\
\hline
\end{tabular}

\subsection{Sistema predial de prevenção e combate a incêndios}

As medidas de segurança contra incêndio constituem-se de "dispositivos ou sistemas a serem instalados nas edificações e em áreas de riscos, necessários para evitar o surgimento de um incêndio, limitar sua propagação, possibilitar sua extinção e ainda propiciar proteção à vida, ao meio ambiente e ao patrimônio" (CARVALHO JUNIOR, 1997).

Segundo este autor, dentre as medidas existentes que visam à proteção contra incêndio em edifícios, as que se referem mais diretamente à arquitetura podem ser agrupadas em dois sistemas: 
(a) medidas ativas de proteção: que abrangem a detecção, o alarme, a iluminação de emergência, a extinção do fogo (automática e/ou manual) e os sistemas de sinalização;

(b) medidas passivas: que envolvem o controle de materiais, meios de escape, compartimentação e proteção da estrutura.

Dentre as medidas ativas que visam à proteção contra incêndios em edificações destacam-se os sistemas hidráulicos de proteção automática (sprinkler ou chuveiro automático) e os sistemas de proteção sob comando (mangotinho e hidrante).

O sistema de hidrantes, de interesse para esta tese, é o mais empregado entre os sistemas sob comando e é regulamentado pela Instrução Técnica n 22/04 do Corpo de Bombeiros do Estado de São Paulo.

Este sistema é composto por tubulações, reservatórios, bombas, hidrantes, mangueiras e requintes. Os hidrantes e as respectivas mangueiras devem ser instalados em abrigos que possuam portas desprovidas de fechadura e serem sinalizados para fácil localização e sem nenhuma obstrução (CARVALHO JUNIOR, 2007).

Poderão ser instalados na parte interna ou externa à edificação, sendo que os instalados na parte interna deverão ser distribuídos de tal forma que se possa alcançar qualquer ponto da área a ser protegida, considerando-se, no máximo, o comprimento de 30 metros de mangueira. Na Figura 3.12 apresenta-se o esquema do sistema de combate por hidrantes. 


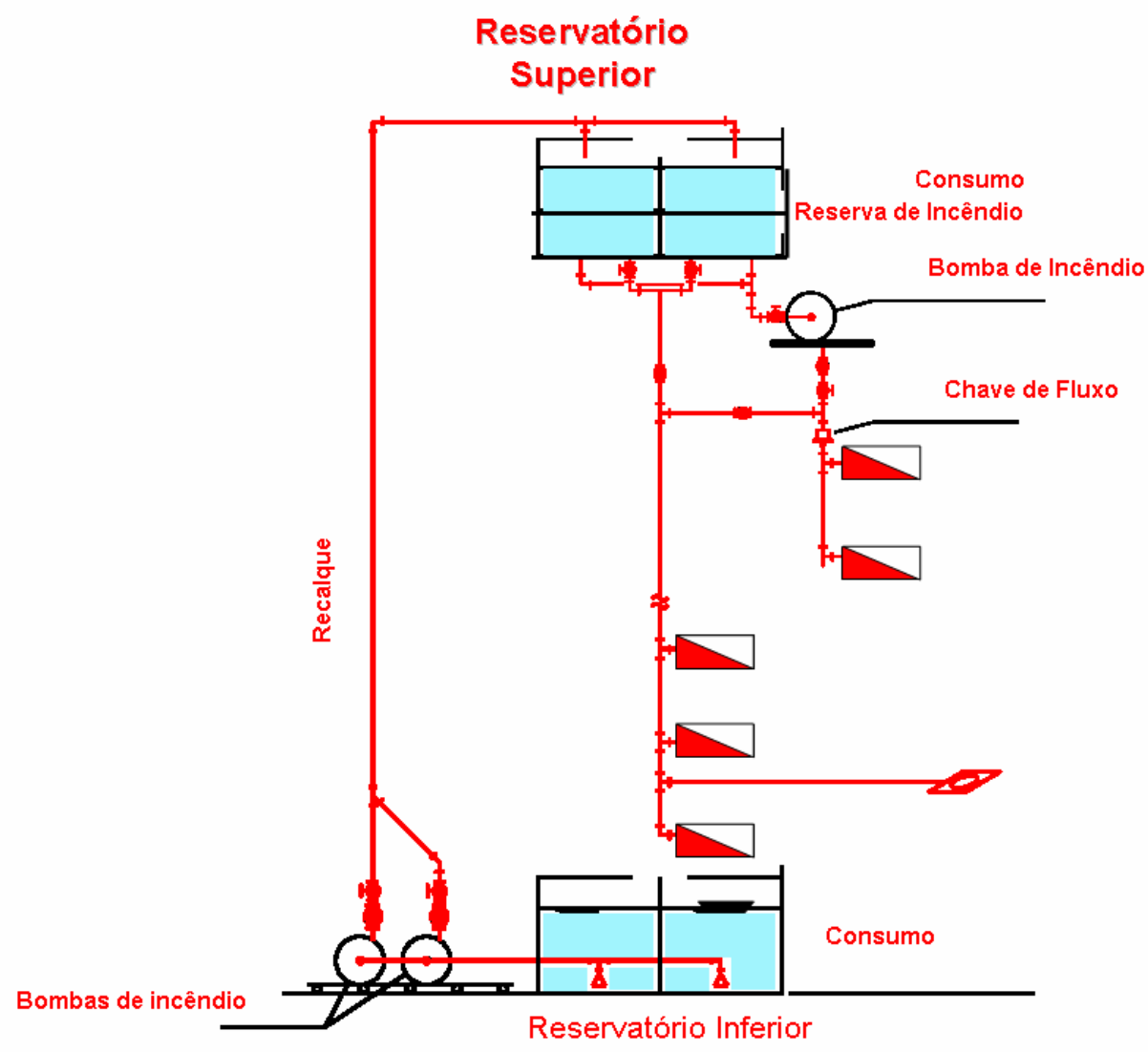

Figura 3.12 - Esquema vertical de um sistema predial de combate a incêndio: hidrantes (GONÇALVES, 2007)

No prolongamento da rede de incêndio da edificação deverá ser previsto um registro de recalque instalado no passeio ou na parede externa da edificação, de fácil acesso e devidamente identificável para o uso pelo Corpo de Bombeiros em caso de incêndios.

Inicialmente o combate ao incêndio, por este sistema, é feito utilizando-se a água armazenada no reservatório superior, denominada reserva de incêndio, cujo volume é previamente calculado no projeto.

Neste caso, o funcionamento dos hidrantes será por gravidade. Para garantir a pressão mínima exigida nos pontos mais desfavoráveis (geralmente os dois últimos pavimentos) faz-se a instalação de uma bomba de incêndio, que é acionada por botoeiras instaladas nestes pavimentos e, porventura, em outros onde a pressão de funcionamento dos hidrantes não é garantida apenas por gravidade. 


\subsection{Sistema predial de esgoto sanitário (SPES)}

\subsubsection{Definição}

Os aspectos relacionados ao projeto, execução, teste e manutenção dos sistemas prediais de esgoto sanitário no Brasil, objetivando o atendimento das exigências mínimas quanto à higiene, segurança e conforto dos usuários, estão dispostos na NBR 8160 (ABNT, 1999).

Segundo esta norma, o sistema predial de esgoto sanitário compreende o conjunto de tubulações e acessórios destinados a coletar e transportar os esgotos sanitários a uma rede pública ou, na ausência desta, a um sistema particular de tratamento, assim como garantir o encaminhamento dos gases para a atmosfera, evitando que os mesmos acessem os ambientes sanitários das edificações.

\subsubsection{Requisitos de desempenho}

Os principais requisitos de desempenho relacionados ao sistema predial de esgoto sanitário dizem respeito ao seu pleno funcionamento sem a ocorrência de contaminação do sistema de suprimento de água (fria ou quente), comprometendo a qualidade da água deste sistema, além de impedir que os gases provenientes do interior das tubulações acessem a área de utilização dos aparelhos sanitários.

Além destes requisitos, a NBR 8160 (ABNT, 1999) acrescenta que este sistema deve permitir o rápido escoamento da água utilizada e dos despejos nele introduzidos, sem a ocorrência de vazamentos e a formação de depósitos no interior das tubulações e, ao mesmo tempo, impossibilitar o acesso de corpos estranhos ao interior do sistema; permitir que os seus componentes sejam facilmente inspecionáveis e impossibilitar que esgoto acesse o subsistema de ventilação. 


\subsubsection{Classificação}

O critério básico de classificação do sistema predial de esgoto sanitário consiste no tipo de subsistema de ventilação a ser utilizado em função do nível de ventilação requerido no mesmo. A ventilação do subsistema de coleta e transporte do esgoto sanitário é necessária para garantir a integridade dos fechos hídricos ${ }^{23}$ existentes, que é comprometida, entre outros fatores, pela variação da pressão pneumática dentro da tubulação de transporte do esgoto sanitário quando da utilização dos aparelhos sanitários.

O sistema predial de esgoto sanitário pode ser classificado ainda, quanto ao dispositivo utilizado na sua ventilação. De acordo com este critério, tem-se o sistema predial de esgoto sanitário com subsistema de ventilação convencional e o sistema predial de esgoto sanitário com sistema de ventilação alternativo, dotado de válvulas de admissão de ar.

\subsubsection{SPES convencional dotado de ventilação primária}

Nesta tipologia, a ventilação do sistema é feita apenas com o prolongamento do tubo de queda na cobertura da edificação, não havendo colunas complementares e paralelas ao mesmo.

\subsubsection{SPES convencional dotado de ventilação primária e secundária}

Nesta tipologia, além da previsão da ventilação primária, conforme exposto anteriormente, há também a adoção de um conjunto de tubulações específicas

${ }^{23}$ Fecho hídrico: camada líquida, de nível constante, que em um desconector veda a passagem dos gases (NBR 8160; ABNT, 1999). 
destinadas à condução dos gases à atmosfera e, ao mesmo tempo, a entrada de ar no sistema para manter a integridade dos fechos hídricos (Figura 3.13).
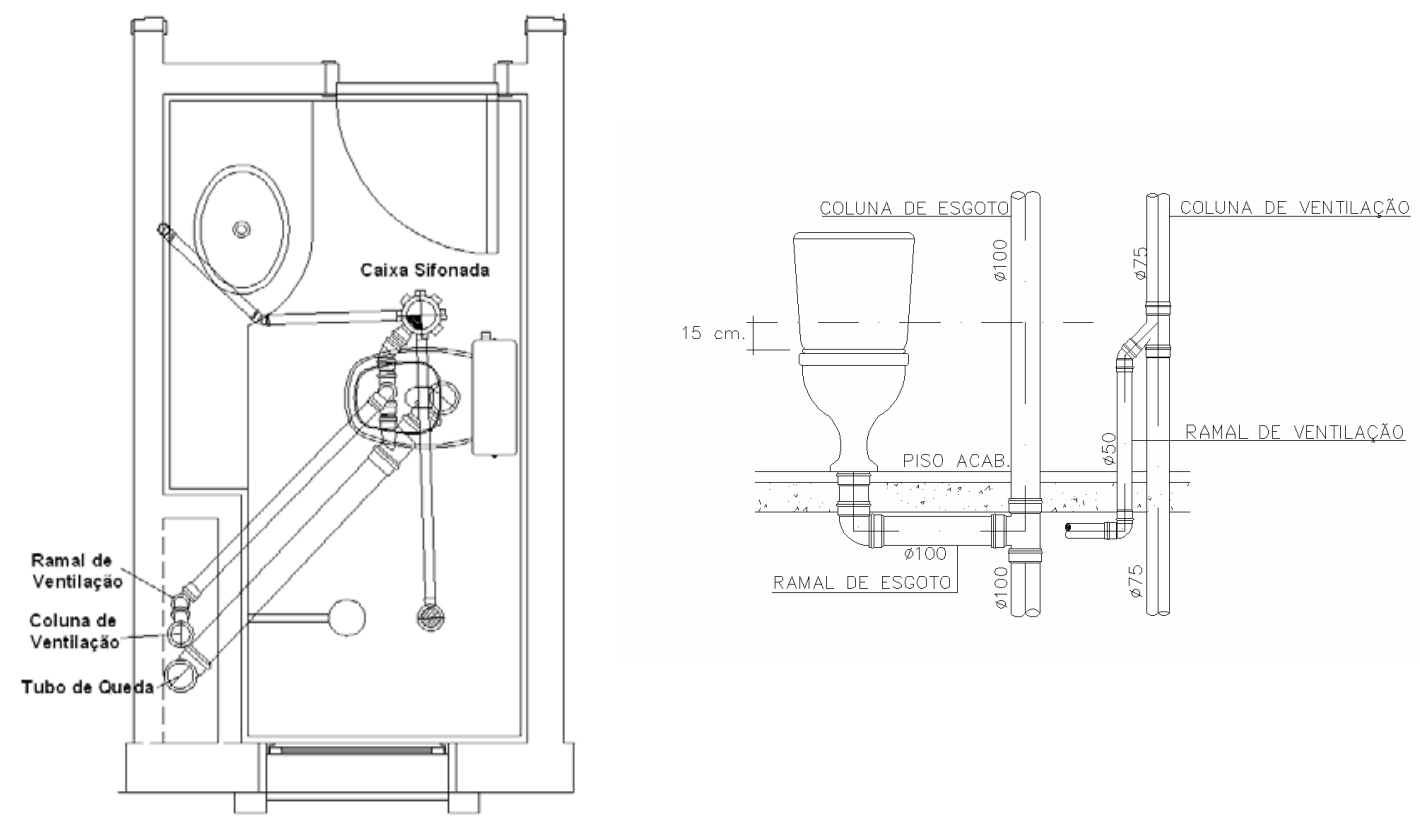

Figura 3.13 - SPES convencional dotado de ventilação secundária (Planta e elevação)

\subsubsection{SPES dotado de válvulas de admissão de ar}

As válvulas de admissão de ar são dispositivos instalados, tanto na ventilação primária quanto na ventilação secundária, que têm por finalidade minimizar a variação das pressões pneumáticas atuantes em um sistema predial de esgotos sanitários quando em uso (MASINI; GONÇALVES, 1999).

Quando instaladas nos ambientes sanitários, ou seja, próximas aos desconectores, dispensam o uso de diversas tubulações existentes no subsistema de ventilação secundária convencional.

Estas válvulas possuem um diafragma que abre ou fecha de acordo com as pressões pneumáticas atuantes no sistema. Com o aumento da pressão pneumática negativa (ou depressão pneumática), este diafragma se abre, permitindo a entrada de ar 
exterior para o interior do sistema até o momento em que esta pressão seja reduzida, quando então este diafragma retorna à posição fechada impedindo que o ar interior alcance o ambiente sanitário no qual as mesmas estão instaladas (MASINI; GONÇALVES, 1999).

Segundo estes autores, encontram-se disponíveis no mercado diversas marcas de válvulas de admissão de ar, com variações na sua denominação e dimensões, mas com o mesmo princípio de funcionamento exposto anteriormente.

Como exemplo, destacam-se: as válvulas de admissão de ar produzidas pela STUDOR, OSMAVENT, AYRLETT, DURGO E OATEY, entre outras. Na Figura 3.14 são ilustradas duas marcas de válvulas de admissão de ar fornecidas pela STUDOR.

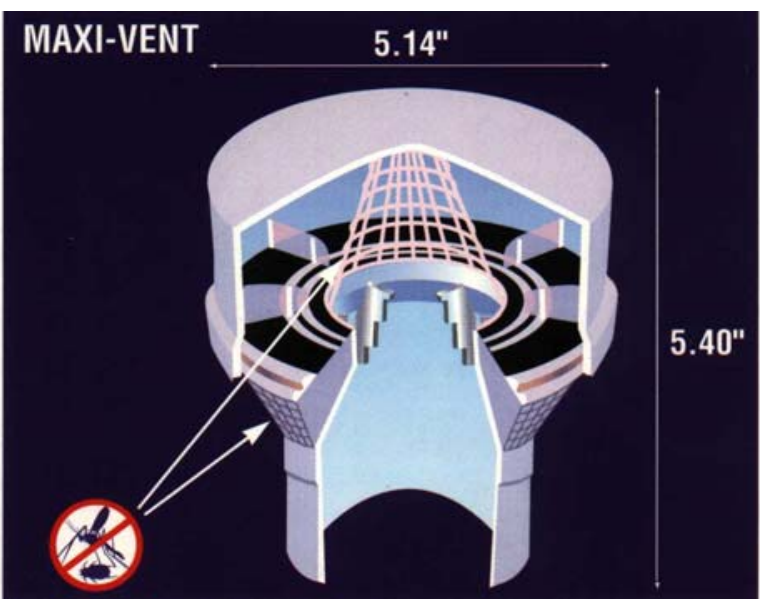

(a)

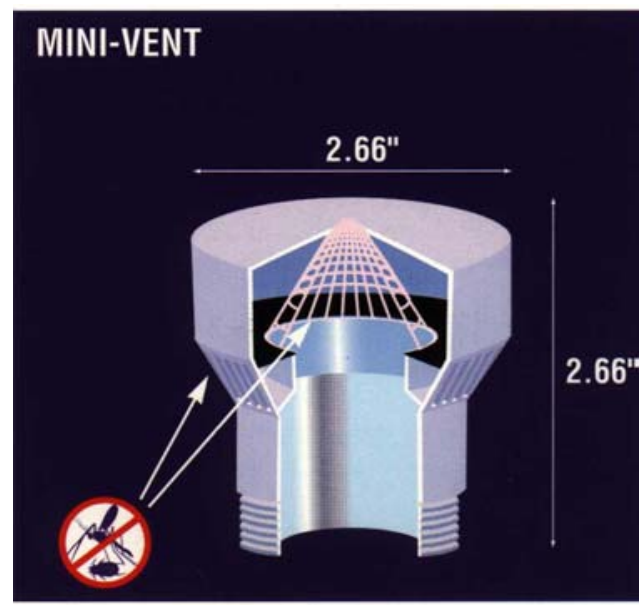

(b)

Figura 3.14 - Válvulas de admissão de ar: a) Válvula Max-Vent ${ }^{\circledR}$; b) Válvula Mini-Vent ${ }^{\circledR}$ (AMORIM, 2006)

As válvulas de admissão de ar Max-Vent ${ }^{\circledR}$ são instaladas no topo do tubo de queda e possuem dimensões maiores em relação às Mini-Vent ${ }^{\circledR}$, que são instaladas nos ramais de descarga e de esgoto (AMORIM, 2006). 


\subsubsection{Partes constituintes}

O sistema predial de esgoto sanitário é dividido em dois subsistemas: o de coleta e transporte do esgoto sanitário que consiste no conjunto de aparelhos sanitários, tubulações e acessórios destinados a captá-lo e conduzi-lo a um destino adequado, e o de ventilação, que consiste em um conjunto de tubulações ou dispositivos destinados a encaminhar os gases para a atmosfera e evitar que os mesmos se encaminhem para os ambientes sanitários, sendo que o subsistema de ventilação pode ser dividido em ventilação primária e secundária (NBR 8160, ABNT 1999).

Além destes subsistemas, Amorim (2006) acrescenta a esta subdivisão o subsistema de disposição do esgoto sanitário. Esses subsistemas, assim como os principais elementos são apresentados na Tabela 3.6.

Tabela 3.6 - Elementos do sistema predial de esgoto sanitário

\begin{tabular}{|l|l|}
\hline Subsistemas & Elementos \\
\hline Coleta e transporte & Aparelhos sanitários \\
& Ramais de descarga \\
& Ramais de esgoto \\
& Tubos de queda \\
& Subcoletores \\
& Coletores \\
\hline Ventilação & Barrilete de ventilação \\
& Ramal de ventilação \\
& Tubo de ventilação \\
\hline Disposição & Caixas de gordura \\
& Poço de águas servidas \\
& Instalação elevatória \\
\hline
\end{tabular}

\subsubsection{Subsistema de coleta e transporte do esgoto sanitário}

O subsistema de coleta e transporte do esgoto sanitário consiste em um conjunto de aparelhos sanitários, tubulações e acessórios destinados a captá-lo e conduzi-lo a um 
destino adequado. A Figura 3.15 ilustra as partes constituintes deste subsistema, enquanto que, a definição/função de cada elemento, é descrita na Tabela 3.7.

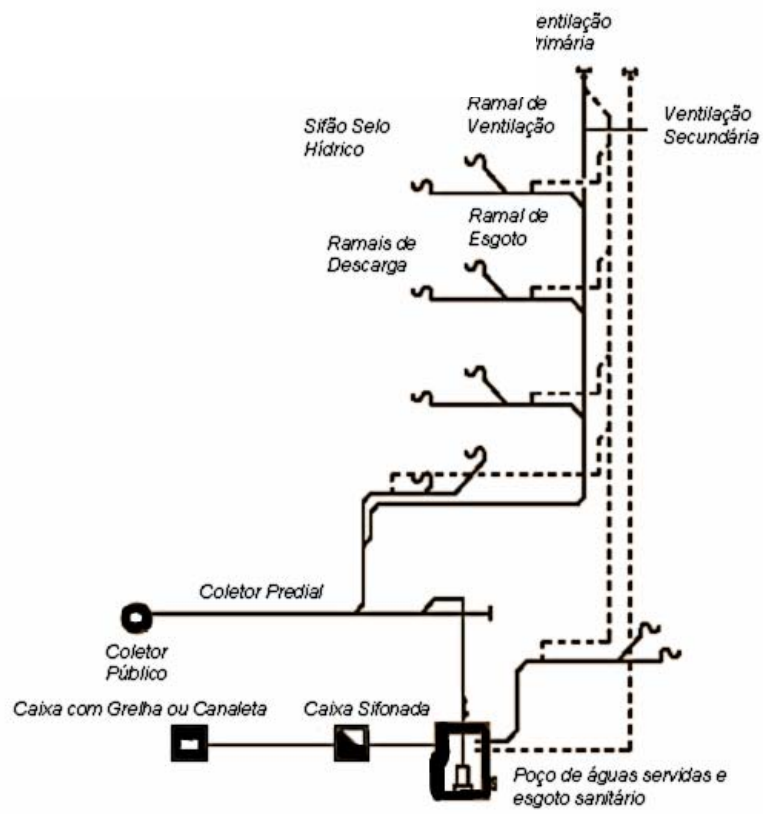

Figura 3.15 - Partes constituintes do sistema predial de esgoto sanitário (GONÇALVES, 2007)

Tabela 3.7 - Principais elementos do subsistema de coleta e transporte de esgoto sanitário (NBR 8160; ABNT, 1999)

\begin{tabular}{|l|l|}
\hline Elemento & Descrição/função \\
\hline Aparelho sanitário & $\begin{array}{l}\text { Aparelho ligado à instalação predial e destinado ao uso de água para fins } \\
\text { higiênicos ou a receber dejetos ou águas servidas }\end{array}$ \\
\hline Ramal de descarga & Tubulação que recebe diretamente os efluentes de aparelhos sanitários \\
\hline Ramal de esgoto & $\begin{array}{l}\text { Tubulação primária que recebe os efluentes dos ramais de descarga, } \\
\text { diretamente, ou a partir de um desconector }\end{array}$ \\
\hline Tubo de queda & $\begin{array}{l}\text { Tubulação vertical que recebe efluentes de subcoletores, ramais de esgoto e } \\
\text { ramais de descarga }\end{array}$ \\
\hline Subcoletor & $\begin{array}{l}\text { Tubulação que recebe efluentes de um ou mais tubos de queda ou ramais de } \\
\text { esgoto }\end{array}$ \\
\hline Coletor predial & $\begin{array}{l}\text { Trecho de tubulação compreendido entre a última inserção de subcoletor, ramal } \\
\text { de esgoto ou de descarga, ou caixa de inspeção geral e o coletor público ou } \\
\text { sistema particular }\end{array}$ \\
\hline
\end{tabular}

Fonte: NBR 8160 (ABNT, 1999)

Todos os trechos horizontais deste subsistema devem apresentar uma declividade mínima constante de forma a possibilitar o escoamento dos efluentes por gravidade. 
Esta recomendação aplica-se tanto aos ramais de descarga quanto aos de esgoto e, inclusive, aos subcoletores e coletores prediais.

Esta declividade é especificada em função do diâmetro da tubulação. De acordo com a norma, para tubulações com diâmetro nominal igual ou inferior a $75 \mathrm{~mm}$ o seu valor é $2 \%$, enquanto que para tubulações cujo diâmetro nominal seja igual ou superior a 100 mm o seu valor deve-se adotar $1 \%$.

Recomenda-se, também, que as mudanças de direção nestes trechos devam ser realizadas com peças com ângulo central igual ou inferior a $45^{\circ}$. No caso dos subcoletores e coletores, estas peças devem vir acompanhadas de elementos que permitam a inspeção destes elementos.

Com relação às tubulações verticais (tubos de queda), estas devem ser preferencialmente projetadas em um único alinhamento. Caso seja necessário realizar desvios, estes devem ser feitos, de preferência com curvas de raio longo ${ }^{24}$ ou duas curvas de $45^{\circ}$.

Uma atenção especial deve ser dada aos tubos de quedas destinados ao recebimento de efluentes de aparelhos sanitários contendo produtos formadores de espuma (detergente, sabão em pó, por exemplo), como: pias, máquinas de lavar roupas e tanques. Nestes casos, visando evitar o retorno de espuma para os ambientes sanitários não se deve efetuar ligações de tubulações de esgoto ou ventilação nas regiões de ocorrência de sobrepressão (pressão pneumática positiva) (trechos hachurados na cor cinza na Figura 3.16), efetuar o desvio do tubo de queda para a horizontal com dispositivos que atenuem esta sobrepressão (curva de $90^{\circ}$ de raio longo ou duas curvas de $45^{\circ}$ ) ou instalar dispositivo anti-retorno de espuma (Figura 3.16).

\footnotetext{
${ }^{24}$ Curva de raio longo: conexão em forma de curva cujo raio de curvatura é maior ou igual a duas vezes o diâmetro interno da peça (NBR 8160; ABNT 1999).
} 


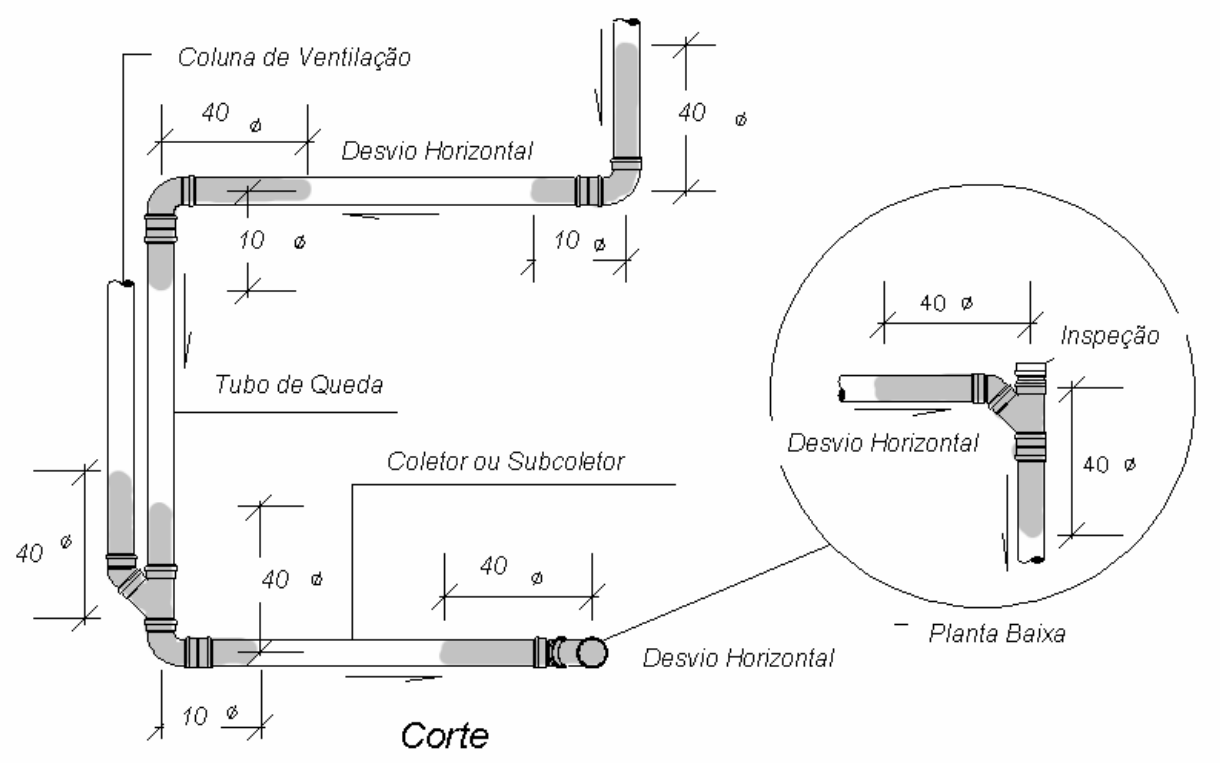

Figura 3.16 - Zonas de sobrepressão segundo a NBR 8160 (ABNT, 1999)

\subsubsection{Subsistema de ventilação}

O subsistema de ventilação primária convencional é representado pelo prolongamento do tubo de queda acima do ramal mais alto a ele ligado. Sua extremidade superior é aberta à atmosfera e situa-se acima da cobertura da edificação, a uma distância que impossibilite o encaminhamento à mesma das águas pluviais provenientes da cobertura da edificação (Figura 3.17). 


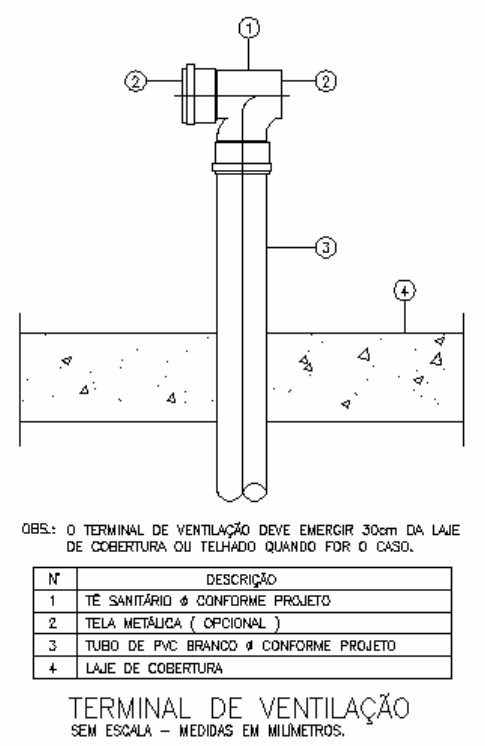

Figura 3.17 - Subsistema de ventilação primária (TESIS, 2007)

Já o subsistema de ventilação secundária convencional é composto pela coluna de ventilação e pelo ramal de ventilação. A coluna de ventilação consiste em um tubo ventilador vertical que se prolonga através de um ou mais andares e, cuja extremidade superior, é aberta à atmosfera ou ligada a tubo ventilador primário ou, ainda, a um barrilete de ventilação.

Já o ramal de ventilação consiste em um tubo que interliga o desconector ou ramal de descarga ou ramal de esgoto, de um ou mais aparelhos sanitários, a uma coluna de ventilação ou a um tubo ventilador primário.

Ao contrário das tubulações horizontais do subsistema de coleta e transporte de esgoto sanitário, as tubulações horizontais do subsistema de ventilação secundária devem ser instaladas com aclive mínimo de $1 \%$, de modo a evitar a entrada do esgoto neste subsistema.

A extremidade inferior da coluna de ventilação deve ser ligada a um subcoletor ou a um tubo de queda em ponto situado abaixo da ligação do primeiro ramal de esgoto ou descarga ou nos mesmos. 


\subsection{Sistema predial de escoamento de águas pluviais}

\subsubsection{Definição}

O sistema predial de escoamento de águas pluviais se destina à captação, condução e destinação a local adequado das águas de chuvas que se precipitam sobre os edifícios incluindo as coberturas, as paredes inclinadas e verticais, os terraços, marquises, as rampas e pequenas

\subsubsection{Requisitos de desempenho}

De acordo com a NBR 10844 (ABNT, 1989), o sistema predial de escoamento de águas pluviais deve ser projetado de tal forma que atenda aos seguintes requisitos:

(a) os condutores de águas pluviais não podem ser utilizados para receber efluentes de esgotos sanitários ou como tubos de ventilação do sistema predial de esgoto sanitários;

(b) ser estanque e permitir a limpeza e obstrução de qualquer ponto do sistema;

(c) resistir às solicitações decorrentes das variações térmicas e dos choques mecânicos e não provocar ruídos.

\subsubsection{Partes constituintes}

O sistema predial de escoamento de águas pluviais é composto pela cobertura (telhados ou pelas próprias lajes estruturais), calhas e rufos, condutores verticais (tubos de queda), condutores horizontais e ralos, caixas de areia, caixas de inspeção e poços de visita. 
Os condutores verticais, segundo a NBR 10844 (ABNT, 1989), são destinados ao recolhimento das águas de calhas, coberturas, terraços e similares e conduzi-las até a parte inferior do edifício. Podem ser colocados tanto na parte externa quanto na interna ao edifício, dependendo das considerações de projeto. Já os condutores horizontais devem ser projetados com declividade uniforme com valor mínimo de $0,5 \%$.

\subsection{Materiais empregados nos componentes para os sistemas prediais}

O atual mercado de tubos e peças para sistemas prediais oferece aos profissionais ligados ao projeto e execução destes sistemas uma variedade maior de materiais do que em tempos atrás. Basicamente hoje o mercado vive uma disputa entre os materiais metálicos, reduzidos basicamente ao cobre, e os materiais plásticos, reforçados com a inserção de novas opções como o polietileno reticulado e o PPR, utilizados na condução de água fria e quente.

$\mathrm{Na}$ Tabela 3.8 são apresentados os principais materiais empregados nos tubos e conexões utilizados nos sistemas prediais abordados no presente trabalho. 
Tabela 3.8 - Materiais empregados nos tubos e conexões utilizados nos sistemas prediais

\begin{tabular}{|c|c|}
\hline Sistema Predial & Material \\
\hline Suprimento de água fria & $\begin{array}{ll}\text { - } & \text { Cloreto de Polivinila (PVC) } \\
\text { - } & \text { Polietileno de alta densidade (PEAD) } \\
\text { - } & \text { Cobre } \\
\text { - } & \text { Aço galvanizado } \\
\text { - } & \text { Polipropileno Copolímero Randon (PPR) } \\
\text { - } & \text { Polietileno Reticulado (PEX) }\end{array}$ \\
\hline Suprimento de água quente & $\begin{array}{ll}\text { - } & \text { Cobre } \\
\text { - } & \text { Policloreto de Vinila Clorado (CPVC) } \\
\text { - } & \text { Polietileno Reticulado (PEX) } \\
\text { - } & \text { Polipropileno Copolímero Randon (PPR) }\end{array}$ \\
\hline Esgoto sanitário & $\begin{array}{ll}\text { - } & \text { Cloreto de Polivinila (PVC) } \\
\text { - } & \text { Ferro fundido } \\
\text { - } & \text { Manilha cerâmica } \\
\end{array}$ \\
\hline Águas pluviais & - $\quad$ Cloreto de Polivinila (PVC) \\
\hline Suprimento de gás & - Cobre \\
\hline Combate a incêndio & $\begin{array}{ll}\text { - } & \text { Cobre } \\
\text { - } & \text { Aço galvanizado }\end{array}$ \\
\hline
\end{tabular}

Fonte: Gonçalves et. al (2000)

Mas, sem dúvida, a grande revolução em termos de materiais empregados nestes sistemas ocorreu com o advento do policloreto de vinila, mais conhecido como PVC, que veio substituir, em grande parte, a partir dos anos 60 , os tubos de ferro fundido e de manilha cerâmica utilizados em sistemas prediais de esgoto sanitário e os de aço galvanizado, utilizados no sistema predial de suprimento de água fria.

Além do PVC, verificou-se também uma substituição gradativa dos tubos e conexões de aço galvanizado pelos de cobre nos sistemas prediais de suprimento de água quente, gás e combate a incêndio. Esta substituição se deu, principalmente, pela leveza dos componentes fabricados com este material, facilitando seu transporte e manuseio e a execução dos serviços. 
Concebido originalmente para ser utilizado em aquecimento de ambientes das edificações localizadas em países de clima temperado e frio sob a forma de aquecimento através de piso radiante, o PEX passou a ser utilizado também nos sistemas prediais de suprimento de água fria e água quente das edificações.

No Brasil, a sua inserção iniciou-se na década de 90, através de sua importação e distribuição por empresas nacionais, configurando-se, assim, em uma inovação tecnológica aplicada à indústria de construção civil ${ }^{25}$.

Por ser um país de clima tropical, o PEX é aplicado quase que na sua totalidade nos sistemas prediais de suprimento de água fria e água quente, em substituição aos materiais tradicionalmente empregados nestes sistemas, como o PVC, CPVC e o cobre.

Atualmente está sendo comum, tanto na Capital quanto em grandes cidades do interior do Estado de São Paulo, o uso do PPR como alternativa aos outros materiais na execução dos sistemas prediais de água fria e água quente.

\subsubsection{PVC}

O cloreto de polivinila é um material termoplástico obtido através da polimerização do monômero cloreto de vinila (MVC), tendo em sua composição $57 \%$ de insumos provenientes do sal marinho ou da terra (salgema) e $43 \%$ de insumos provenientes de fontes não renováveis, como o petróleo e o gás natural (RODOLFO JR. et al., 2006).

Segundo estes autores, trata-se de um material muito versátil devido, principalmente, ao seu processo de fabricação, no qual se faz a incorporação de diversos aditivos à

\footnotetext{
${ }^{25}$ Esta década foi marcada pela abertura do mercado nacional ao capital estrangeiro, assim como às tecnologias do primeiro mundo, motivada pela paridade do Real em relação ao Dólar.
} 
resina de PVC e, em parte, por se adequar aos mais diversos processos de moldagem, como a extrusão, injeção, calandragem entre outros.

Dentre os setores da economia brasileira, dados da BRASKEM (Petroquímica Brasileira de Classe Mundial) indicam que o setor de Construção Civil corresponde por $62 \%$ do consumo deste material no país sendo, na sua maioria, representado pelos tubos e conexões $(45 \%)$.

A exposição do polímero PVC, sem a adição de estabilizantes ao calor, à radiação ultravioleta ou, ainda, à radiação gama, pode, dependendo da intensidade e tempo de exposição, causar a liberação de cloreto de hidrogênio $(\mathrm{HCl})$, acompanhado da formação de seqüências poliênicas e ligações cruzadas na cadeia, resultando em um rápido processo de degradação, revelado normalmente pela mudança de coloração para amarelo até o marrom escuro. Este processo é conhecido como desidrocloração (RODOLFO JR. et al., 2006).

\subsubsection{CPVC}

O CPVC ou Policloreto de Vinila Clorado é o nome dado às resinas termoplásticas produzidas pela pós-cloração da resina de PVC, na qual o gás cloro é forçado a passar em contra-corrente com a lama de resina de PVC, substituindo parte dos átomos de hidrogênio presentes na cadeia do PVC, aumentando, portanto, o teor de cloro do polímero base de $56,7 \%$ para valores tipicamente entre $63 \%$ e $68 \%$, podendo chegar até $73,2 \%$, valor máximo do teor de cloro teoricamente substituível no PVC (RODOLFO JR, et al., 2006).

Segundo estes autores, o principal efeito decorrente deste processo nas cadeias do PVC é o aumento das forças de atração intermoleculares, proporcionando o aumento 
das propriedades térmicas deste material, assim como melhoria da sua resistência química a agentes diversos e a resistência ao fogo.

\subsubsection{Cobre}

Os tubos de cobre são fabricados por extrusão com 99,9\% de cobre recozido e uma quantidade máxima de 0,04\% de fósforo (GONÇALVES et al., 2000).

São divididos em 3 classes: E, A e I, conforme Tabela 3.9. As características dos tubos são apresentadas na Tabela 3.10.

Tabela 3.9 - Classes dos tubos de cobre e seus respectivos usos

\begin{tabular}{|c|c|c|}
\hline Classe & Identificação & Uso \\
\hline$E$ & $\begin{array}{l}\text { Presença de tampões plásticos na } \\
\text { extremidade da tubulação na cor verde }\end{array}$ & $\begin{array}{l}\text { Para instalações de água fria e água quente, } \\
\text { instalações de combate a incêndio por hidrante e } \\
\text { sprinklers }\end{array}$ \\
\hline A & $\begin{array}{l}\text { Presença de tampões plásticos na } \\
\text { extremidade da tubulação na cor amarela }\end{array}$ & $\begin{array}{l}\text { São indicados para todas as aplicações de tubos } \\
\text { classe E, bem como para instalações de gases } \\
\text { combustíveis }\end{array}$ \\
\hline I & $\begin{array}{l}\text { Presença de tampões plásticos na } \\
\text { extremidade da tubulação na cor azul }\end{array}$ & $\begin{array}{l}\text { São indicados para todas as aplicações de tubos } \\
\text { classe A, bem como para instalações industriais } \\
\text { de alta pressão e vapor. }\end{array}$ \\
\hline
\end{tabular}

Fonte: catálogo de produtos da Eluma (ELUMA, 2000)

Tabela 3.10 - Tubos de cobre: espessura das paredes e pressão de serviço por Classe

\begin{tabular}{|c|c|c|c|c|c|c|}
\hline \multirow{2}{*}{$\begin{array}{c}\text { Diâmetro } \\
(\mathbf{m m})\end{array}$} & $\begin{array}{c}\text { Espessura } \\
\text { da parede } \\
(\mathbf{m m})\end{array}$ & $\begin{array}{c}\text { Pressão de } \\
\text { serviço } \\
\mathbf{( k g / \mathbf { c m } ^ { 2 } )}\end{array}$ & $\begin{array}{c}\text { Espessura } \\
\text { da parede } \\
(\mathbf{m m})\end{array}$ & $\begin{array}{c}\text { Pressão de } \\
\text { serviço } \\
\left(\mathbf{k g} / \mathbf{c m}^{\mathbf{2}}\right)\end{array}$ & $\begin{array}{c}\text { Espessura } \\
\text { da parede } \\
(\mathbf{m m})\end{array}$ & $\begin{array}{c}\text { Pressão de } \\
\text { serviço } \\
\left(\mathbf{k g} / \mathbf{c m}^{\mathbf{2}}\right)\end{array}$ \\
\hline 15 & 0,5 & 41,0 & 0,7 & 60,0 & 1,0 & 88,0 \\
\hline 22 & 0,6 & 34,0 & 0,9 & 50,0 & 1,1 & 60,0 \\
\hline 28 & 0,6 & 26,0 & 0,9 & 40,0 & 1,2 & 55,0 \\
\hline 35 & 0,7 & 25,0 & 1,1 & 40,0 & 1,4 & 45,0 \\
\hline 42 & 0,8 & 24,0 & 1,1 & 35,0 & 1,4 & 42,0 \\
\hline 54 & 0,9 & 21,0 & 1,2 & 28,0 & 1,5 & 34,0 \\
\hline 66,7 & 1,0 & 20,0 & 1,2 & 24,0 & 1,5 & 28,0 \\
\hline 79,4 & 1,2 & 19,0 & 1,5 & 24,0 & 1,9 & 27,0 \\
\hline 104,8 & 1,2 & 14,0 & 1,5 & 18,0 & 2,0 & 20,0 \\
\hline
\end{tabular}

Fonte: catálogo de produtos da Eluma (ELUMA, 2000) 


\subsubsection{PEX}

O polietileno reticulado é fabricado a partir de uma matéria-prima plástica com elevado peso molecular (HDPE - polietileno de alta densidade) e é comumente designado pela sigla PEX, onde "PE" significa polietileno e "X" indica que as ligações químicas são cruzadas (GONÇALVES, 1994).

O polietileno é uma resina plástica composta de macromoléculas lineares constituídas de hidrogênio e carbono em ligações alternadas. A reticulação consiste em expulsar o hidrogênio do sistema, através de um processo físico-químico, fazendo com que as novas ligações espaciais formadas de carbono-carbono gerem um produto com qualidades diferenciadas do polietileno normal. Estabelecem-se, então, ligações químicas entre as cadeias do polietileno, formando uma rede tridimensional (PEX do Brasil, 2005).

A Figura 3.18 ilustra a diferença entre a cadeia molecular do polietileno normal e o polietileno reticulado, onde se identifica a ponte molecular entre as moléculas das cadeias de polietileno.

\section{PEX}

\section{Polietileno Reticulado}

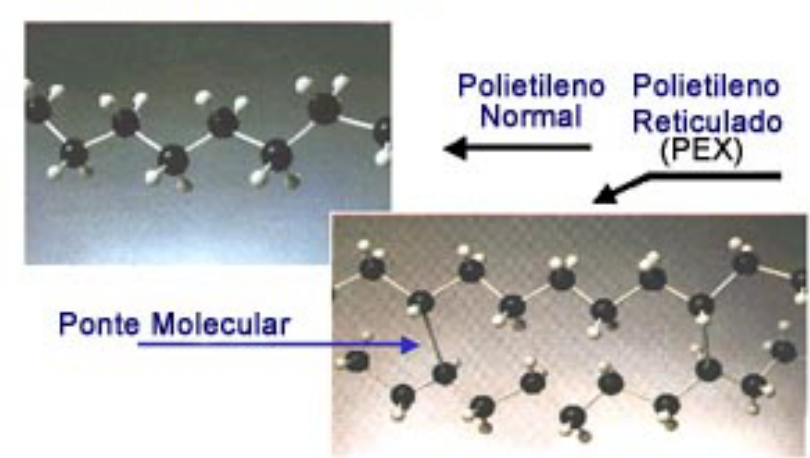

Figura 3.18 - Comparação entre a estrutura molecular do polietileno normal e do polietileno reticulado (PEX) - (PEX do Brasil, 2005) 


\section{Capitulo 4}

\section{MÉTODO DE COLETA E PROCESSAMENTO DOS DADOS}

A confiabilidade dos resultados sobre produtividade da mão-de-obra depende de um excelente planejamento da coleta de dados e sua correta implementação depende da elaboração dos instrumentos de coleta de dados que leve em consideração os seus fatores potencialmente influenciadores.

Tais aspectos tornam-se mais importantes ainda em se tratando dos sistemas prediais hidráulicos, uma vez que envolvem um grande número de tarefas e subtarefas, além do fato de haver várias frentes de trabalho acontecendo ao mesmo tempo em locais (pavimentos) distintos, ao contrário, por exemplo, da execução da concretagem, montagem de fôrmas e, até mesmo, da execução da alvenaria.

No que diz respeito ao levantamento do consumo unitário de materiais, por se tratar de uma coleta de dados que tem como fonte básica de informações os projetos dos sistemas prediais, os dados devem ser organizados de tal forma a subsidiar também o cálculo da produtividade da mão-de-obra, uma vez que o levantamento de informações para o cálculo do consumo unitário de materiais é parte comum e intermediária ao cálculo da produtividade. 
Estas constatações foram frutos do Estudo Piloto realizado antes do início da coleta de dados no conjunto de obras, além do aprendizado contínuo adquirido ao longo da coleta de dados nas obras de maior complexidade subseqüentes ao mesmo.

Assim, este capítulo é dedicado à apresentação do método de coleta e processamento de dados inerentes à obtenção dos indicadores de produtividade da mão-de-obra e consumo unitário de materiais na execução dos sistemas prediais hidráulicos.

\subsection{Experiências obtidas e diretrizes a serem seguidas a partir do estudo piloto}

Embora os sistemas prediais deste Estudo Piloto apresentassem pouca complexidade, a experiência obtida serviu para se ter uma idéia dos caminhos a serem seguidos quanto à elaboração dos instrumentos de coleta, ao planejamento da pesquisa e à forma de abordagem dos funcionários para a obtenção das informações e também ressaltou a necessidade de se encontrar uma forma eficiente e simplificada de se realizar o processamento dos dados coletados.

Estas experiências foram traduzidas em diretrizes aplicáveis às principais variáveis necessárias ao cálculo dos indicadores de produtividade da mão-de-obra e consumo unitário de materiais, conforme serão descritas a seguir.

\subsubsection{Quantidade de serviço}

Os sistemas prediais nem sempre são executados na sua totalidade em um dia de trabalho, ou seja, é comum encontrar-se, ao final do dia, trechos destes sistemas incompletos como, por exemplo, ramais de descarga, sub-ramais de água fria ou água quente, seja pela ocorrência de alguma anormalidade (falta de material, por exemplo) 
ou pela impossibilidade de se finalizar os serviços de um determinado ambiente até o final do expediente.

Assim, não se pode adotar como referência para a quantificação dos serviços um parâmetro que represente um conjunto de componentes (tubulações e conexões) como, por exemplo, pavimento, apartamento ou, até mesmo, o ambiente.

Portando, diante desta constatação, tem-se como diretriz:

Para efeito de quantificação dos serviços e coleta de dados no canteiro de obras, os sistemas prediais deverão ser divididos em partes menores (subsistemas, elementos e componentes).

No entanto, esta divisão deve ser feita de forma a atender as necessidades tanto para o cálculo do consumo unitário de materiais quanto para o cálculo da produtividade da mão-de-obra. Como exemplo, cita-se o caso dos ramais de esgoto sanitário de um determinado ambiente e seu respectivo subsistema de ventilação. Para efeito do cálculo da produtividade da mão-de-obra talvez não seja interessante fazer uma distinção entre o subsistema de escoamento (ramais de descarga e de esgoto) e o subsistema de ventilação secundária (ramais de ventilação), uma vez que o esforço demandado para a execução de ambas as partes pode ser considerado muito parecido e pelo fato de não se conseguir distinguir claramente, durante sua execução, o esforço (homens-hora) demandado em cada um. Já com relação ao consumo unitário de materiais, talvez esta distinção seja interessante e significativa para a realização do seu prognóstico e, neste caso, os sistemas prediais podem ser subdivididos recorrendo-se a sua classificação apresentada no capítulo 3 .

Desta forma, tem-se a seguinte diretriz: 
Os dados devem ser organizados de tal forma a subsidiar simultaneamente tanto o cálculo da produtividade da mão-de-obra quanto do consumo unitário de materiais.

Como decorrência desta $1^{\text {a }}$ diretriz, há que se definir um limite mínimo de subdivisão que atenda aos propósitos desta tese. Assim, para cada sistema predial estabelece-se como limite inferior o trecho de tubulação, conforme a seguinte diretriz:

Para efeito de quantificação dos serviços em projeto e coleta de dados no canteiro de obras, institui-se o trecho de tubulação, compreendido entre duas ou mais conexões, como a menor parte mensurável de um determinado serviço.

Cada trecho de tubulação será caracterizado pelo material constituinte do tubo e seu diâmetro. Além destas características, para efeito de análise da produtividade da mãode-obra e consumo unitário de materiais, será associado a cada trecho o número de conexões, respeitando, para isto, a seqüência de execução das tubulações em cada sistema predial e tendo-se como regra geral a associação do número de conexões existentes a montante de cada trecho.

Assim, no sentido de uniformizar o levantamento desta característica, adotou-se a seguinte diretriz:

Cada trecho de tubulação será caracterizado, além do seu comprimento em metros, pelo material de fabricação, diâmetro comercial e nominal, em milímetros, número de conexões, sendo que esta última característica dependerá do número de conexões existentes a montante de cada trecho.

No caso da análise do consumo unitário de materiais, o número de conexões atende perfeitamente as necessidades propostas nesta tese, uma vez que se utilizará a 
totalidade de conexões e metros de tubulação presentes nos sistemas e subsistemas, portanto, de fácil distinção e contabilização.

Além do fato de se encontrarem ao final do dia de trabalho, ambientes com os respectivos sistemas prediais incompletos, o que pode gerar imprecisões durante a coleta de dados, uma particularidade destes sistemas reside no fato de sua execução acontecer em várias frentes de trabalho, com condições de produção específicas (por exemplo, serviço sob o regime de tarefa ou não), e, até mesmo, em diferentes pavimentos.

Assim, é conveniente que o pesquisador, durante a coleta de dados no canteiro de obras, seja direcionado ao pavimento em que os serviços estejam sendo executados. Desta forma, estabelece-se a seguinte diretriz:

Os instrumentos de coleta de dados devem ser elaborados de tal forma a permitir ao pesquisador coletar os dados relativos à quantidade de serviço diretamente nos pavimentos/ambientes cujos serviços foram executados no dia anterior.

Finalmente, além destas diretrizes relacionadas ao processo de coleta de dados, tanto no canteiro de obras quanto em projetos, há que se uniformizar, também, além da unidade de mensuração da quantidade de serviço [metro(s) de tubulação], a consideração do que vem a ser a quantidade de serviço utilizada para o cômputo tanto da produtividade da mão-de-obra quanto do consumo unitário de materiais. No caso desta presente tese e nos outros diversos trabalhos realizados sobre este assunto sob a luz do Modelo dos Fatores, não são considerados os acréscimos no comprimento da tubulação previstos em orçamentos ou listas de materiais, muitas vezes, parte integrante dos projetos destes sistemas. Disto, deriva-se que: 
Para o cômputo da quantidade de serviço de sistemas prediais (metros de tubulações) considera-se o comprimento "líquido" de tubos, ou seja, isento de possíveis acréscimos previstos em orçamentos ou outra fonte de consulta (acréscimos devido à previsão de perdas na etapa de execução).

\subsubsection{Homens-hora}

Nos estudos sobre produtividade da mão-de-obra há o interesse em se saber a influência das características da equipe executora, no que diz respeito ao cargo de seus integrantes, na execução de um determinado serviço (encarregado, oficial, 1/2 oficial e ajudante). Esta influência pode ser quantificada em termos da relação ajudante/oficial e, mais do que isto, tal informação pode ser útil também para se fazer o dimensionamento desta equipe executora na execução de serviços futuros.

Embora não se tenha ainda identificado claramente nas obras analisadas se esta relação influencia a produtividade da mão-de-obra na execução destes sistemas, há que se fazer esta distinção no momento da coleta de dados, resultando na seguinte diretriz:

No início dos trabalhos de campo, ou previamente aos mesmos, devese conhecer a equipe executora e saber o respectivo cargo de cada integrante, de tal forma a se poder relacioná-los aos indicadores de produtividade da mão-de-obra.

Com relação ao tempo demandado na execução de um serviço (ou parte do mesmo), há que se adotar uma postura única quanto ao que se considerar neste cômputo. Durante o dia de trabalho, além do tempo que o operário dedica à execução dos serviços, tem-se também o tempo destinado às refeições e, eventualmente, a outros 
eventos de diversas naturezas, como participação em reuniões de segurança ou qualidade entre outras situações. Este trabalho segue a mesma postura adotada em trabalhos semelhantes sob a luz do Modelo dos Fatores, através da seguinte diretriz:

Considera-se, para o cômputo da produtividade da mão-de-obra, o tempo no qual o operário ficou disponível para a execução do serviço, excluindo-se deste montante o tempo dedicado a atividades previamente programadas, como: refeições, reuniões técnicas e outras situações de mesma natureza.

Note-se que não se exclui deste escopo o tempo no qual o operário está disponível para a realização do serviço e que, por questões anormais, como a falta de equipamento/ferramentas, falta de material ou qualquer outro impedimento relacionado à gestão do processo de trabalho, não foi possível sua execução. Estas horas devem ser computadas e os motivos pelos quais não se realizou o serviço constituem explicações para um eventual índice de produtividade ruim.

Finalmente, em trabalhos que envolvem a medição de desempenho da mão-de-obra, os objetivos e a forma pela qual os dados serão coletados devem ser explicitados claramente à equipe executora. Esta postura tem como objetivo não gerar desconfiança entre os operários com relação ao trabalho a ser desenvolvido (deve-se garantir a sua não utilização para fins de controle pessoal ou comparação de desempenhos entre operários) e evitar a obtenção de informações errôneas, uma vez que o cômputo das horas gastas é muito importante para o sucesso da coleta de dados. 


\subsection{Etapas do método de coleta e processamento dos dados}

O método de coleta e processamento dos dados é dividido em 3 etapas gerais: planejamento da coleta de dados, coleta de dados propriamente dita e processamento dos dados, cada qual contendo um conjunto de atividades que podem ser comuns ou específicas para a obtenção do consumo unitário de materiais e a produtividade da mão-de-obra.

Na Figura 4.1 são apresentadas estas etapas gerais, assim como o detalhamento das atividades a serem desenvolvidas, as fontes de informações e os produtos obtidos decorrentes de cada ação empreendida.

Ressalta-se que tais atividades não precisam obrigatoriamente ser realizadas na ordem apresentada e nos momentos propostos, podendo haver variações em função do grau de conhecimento da obra por parte do pesquisador.

Na seqüência faz-se o detalhamento destas atividades, contemplando, principalmente, as especificidades de cada sistema predial. 


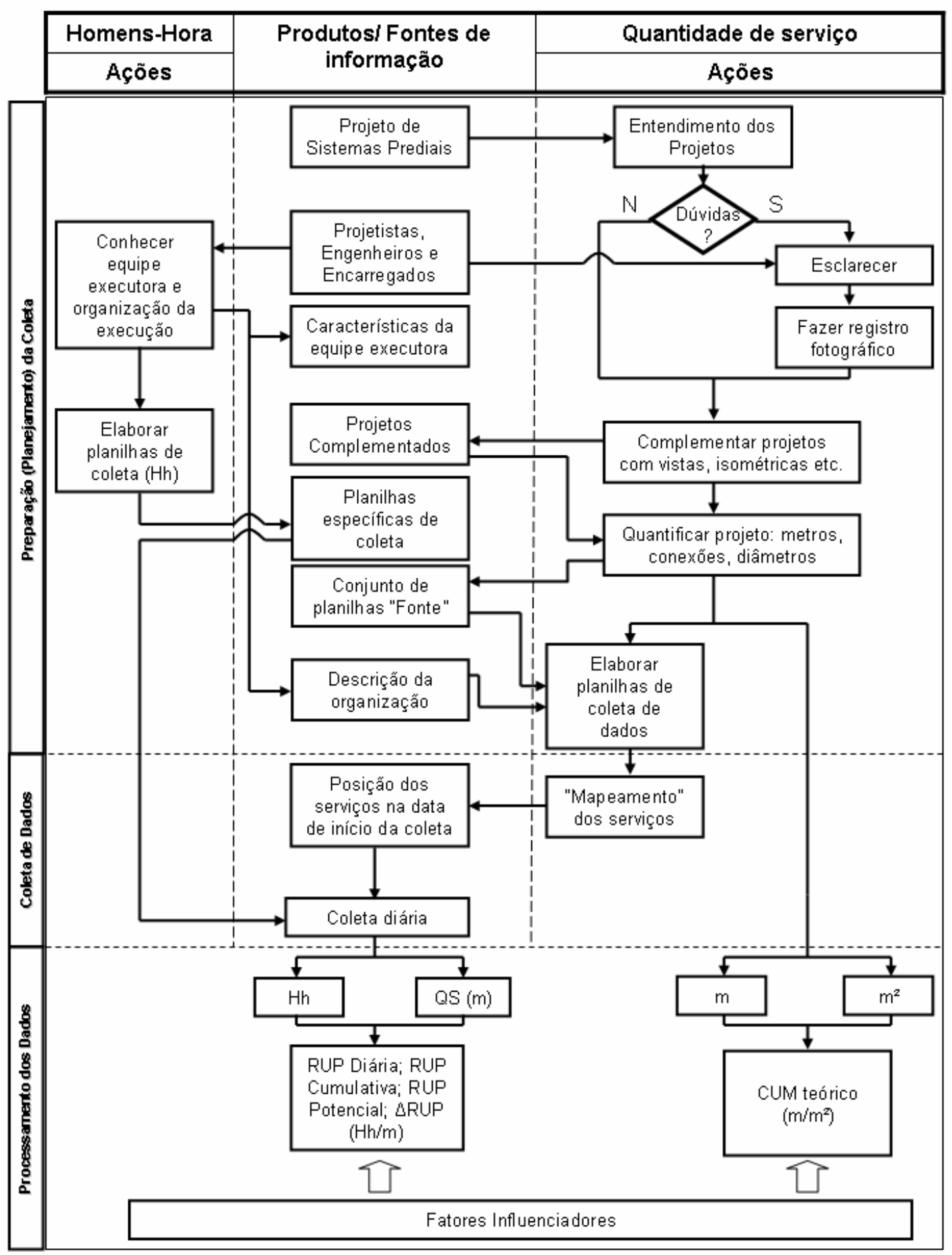

Figura 4.1 - Etapas da coleta de dados e respectivas atividades 


\subsection{Planejamento da coleta de dados}

O planejamento da coleta de dados compreende as seguintes atividades, cujo detalhamento será feito na seqüência: entendimento do projeto; divisão dos sistemas prediais em subsistemas/elementos; subdivisão dos subsistemas/elementos prediais em componentes; caracterização dos trechos quanto ao seu comprimento, número de conexões e diâmetro; elaboração de planilhas de dados eletrônicas primárias (Planilhas "Fonte"); subdivisão dos serviços em tarefas e subtarefas; entendimento da forma de organização da produção e elaboração de planilhas de coleta de dados no canteiro de obras.

\subsubsection{Entendimento do projeto}

De posse dos projetos específicos dos sistemas prediais, o primeiro passo consiste em analisar as várias pranchas com o objetivo de se entender sua concepção (classificação dos sistemas prediais conforme capítulo 3), traçado das tubulações quanto a sua posição (verticais e horizontais), interferência com outros subsistemas (embutimento ou não nas vedações verticais e horizontais, abertura em vigas e lajes da estrutura), o tipo de material empregado nas tubulações e conexões de cada sistema entre outros aspectos.

Neste processo é muito comum surgirem dúvidas a partir do primeiro contato do pesquisador com os projetos de uma determinada obra, principalmente em ambientes onde há maior concentração destes sistemas, como é o caso da área de serviço, que pode abrigar tanto os sistemas prediais de esgoto sanitário e água fria (os básicos) como também os sistemas prediais de suprimento de água quente e gás, sendo estes últimos associados a outros equipamentos, tais como os de medição de consumo e aquecimento. 
Outro aspecto importante diz respeito à adequação dos desenhos existentes nas pranchas à precisão da medição necessária para o desenvolvimento deste trabalho. É muito comum o detalhamento dos sistemas prediais ser feito sob a forma de desenhos isométricos, principalmente dos ramais e sub-ramais de água fria e água quente dos ambientes molháveis. A medição direta do comprimento das tubulações destes, utilizando-se apenas estes desenhos como fonte de consulta, será imprecisa, uma vez que há claramente uma distorção no comprimento das tubulações quando se utiliza este recurso gráfico de apresentação ${ }^{26}$.

Em se tratando do sistema predial de esgoto sanitário, por exemplo, além de haver em alguns casos a sobreposição de tubulações, destaca-se também o grande número de conexões empregadas neste sistema, sendo comum, inclusive, ligações entre duas ou mais conexões em determinados trechos (Figura 4.2).

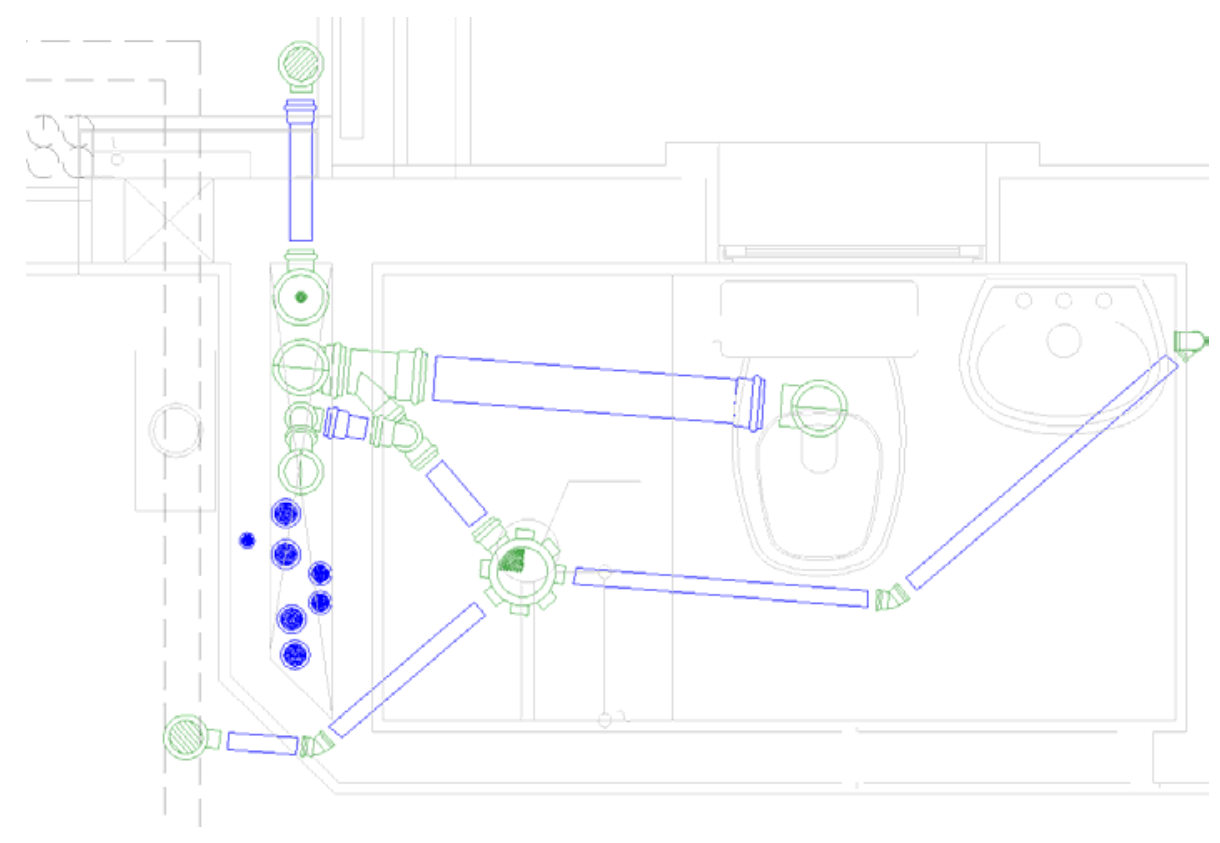

Figura 4.2 - Planta do sistema predial de esgoto sanitário de um ambiente molhável onde se pode verificar o tipo e número de conexões existentes

${ }^{26}$ Obviamente esta preocupação se refere à medição do comprimento do trecho de tubulação utilizando-se um escalímetro. No caso de se obter esta informação utilizando-se recursos do AUTOCAD®, esta preocupação não é pertinente. 
Finalmente, há que se ressaltar também que, durante a execução destes sistemas prediais, pode haver mudanças de traçados de tubulações, com a anuência ou não do projetista, em função da identificação de uma incompatibilidade entre estes sistemas e os de estrutura e de vedação.

Nestes casos, e em outras situações não perfeitamente claras no projeto, o pesquisador deverá complementar as informações necessárias diretamente na obra, através de consulta ao encarregado ou à mão-de-obra executora ou, até mesmo, fazer medições in loco de trechos já executados em determinados pavimentos. Um outro recurso muito útil reside na utilização de registros fotográficos de determinados pontos dos sistemas/subsistemas que necessite de um melhor esclarecimento.

\subsubsection{Divisão dos sistemas prediais em subsistemas/elementos}

Após o pleno entendimento do projeto, parte-se para a quantificação das "partes" dos sistemas prediais. Como primeiro passo, deve-se fazer a divisão destes sistemas levando-se em consideração os seus subsistemas e suas partes.

Esta divisão atende mais aos propósitos do prognóstico do consumo unitário de materiais do que aos da produtividade da mão-de-obra, uma vez que, ao longo da coleta de dados no canteiro de obras, estas partes são executadas simultaneamente, sendo muito impreciso e subjetivo alocar os homens-hora a cada uma delas.

No caso da produtividade da mão-de-obra, prioriza-se a divisão dos serviços em termos das atividades necessárias a sua execução, conforme será descrito no item 4.3.6.

Nas figuras $4.3,4.4$ e 4.5 ilustram-se a subdivisão dos sistemas prediais em suas partes menores para efeito do cálculo do consumo unitário de materiais. 


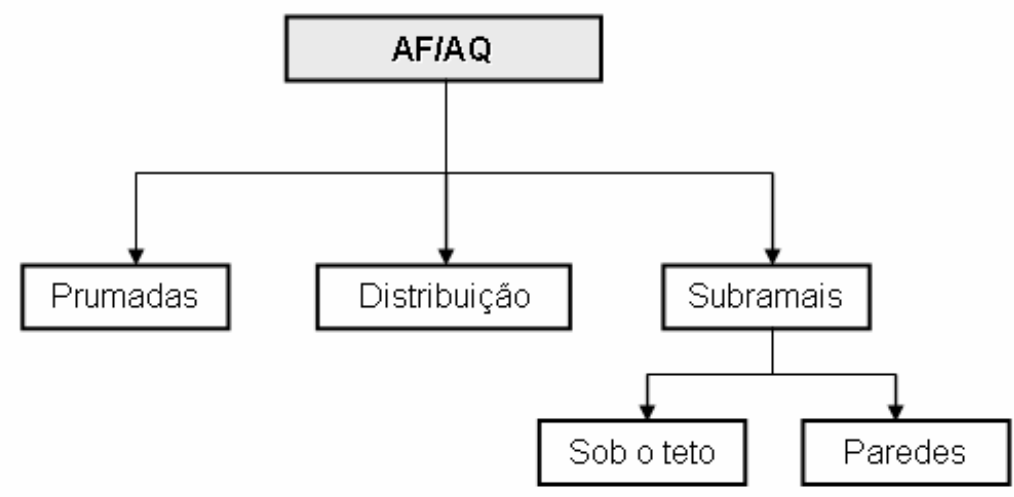

Figura 4.3 - Divisão dos sistemas prediais de suprimento de água fria e água quente
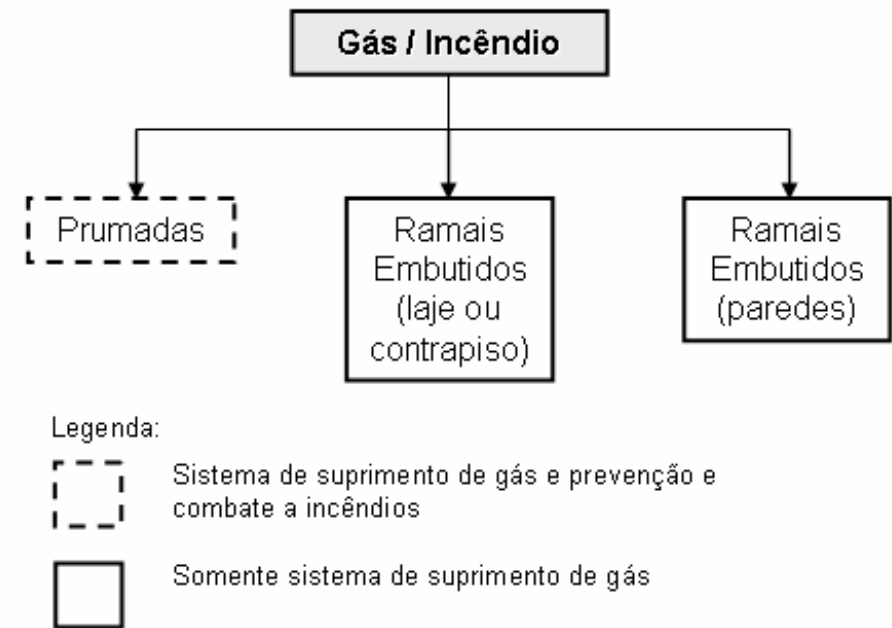

Figura 4.4 - Divisão dos sistemas prediais de suprimento de gás e de prevenção e combate a incêndios 

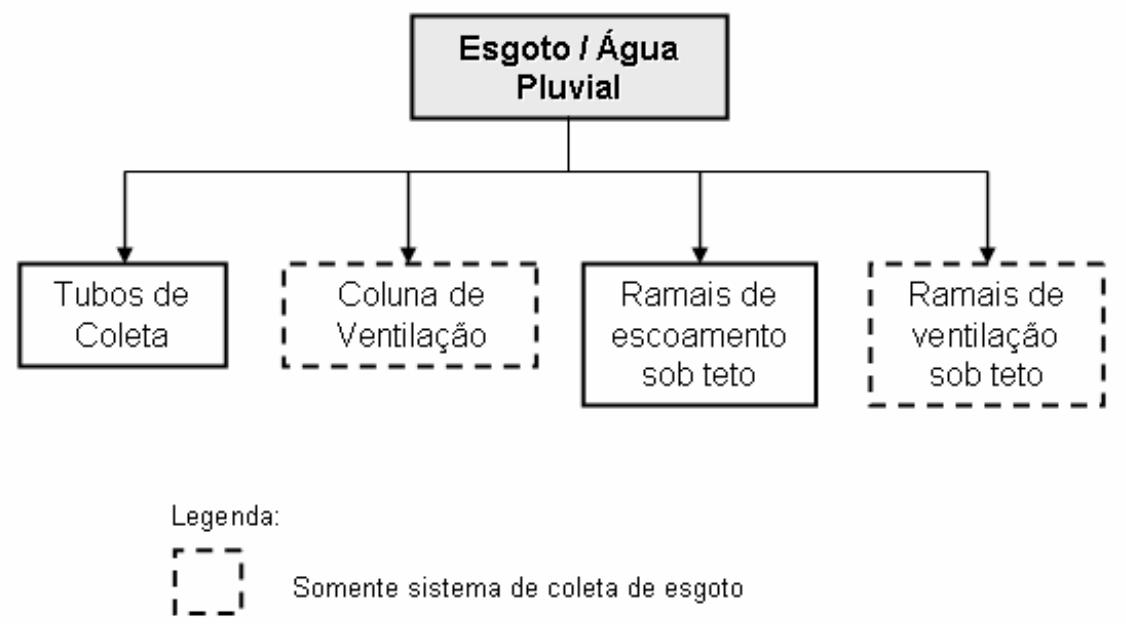

Figura 4.5 - Divisão dos sistemas prediais de coleta de esgoto sanitário e águas pluviais

\subsubsection{Subdivisão dos subsistemas/elementos prediais em componentes}

Após a divisão dos sistemas em seus respectivos subsistemas, procede-se ao detalhamento de cada um subdividindo-os em componentes (tubos e conexões). Em outras palavras, divide-se o conjunto tubos/conexões de um determinado subsistema/elemento em trechos de tubulações tendo-se como premissa a definição de que o trecho de tubulação consiste no comprimento de tubo delimitado pelas conexões localizadas em suas extremidades (Figura 4.6a), conforme diretriz apresentada anteriormente. Há casos em que em uma extremidade do trecho há mais de uma conexão, como é o caso, por exemplo, de trechos delimitados por registro de gaveta (Figura 4.6b). 

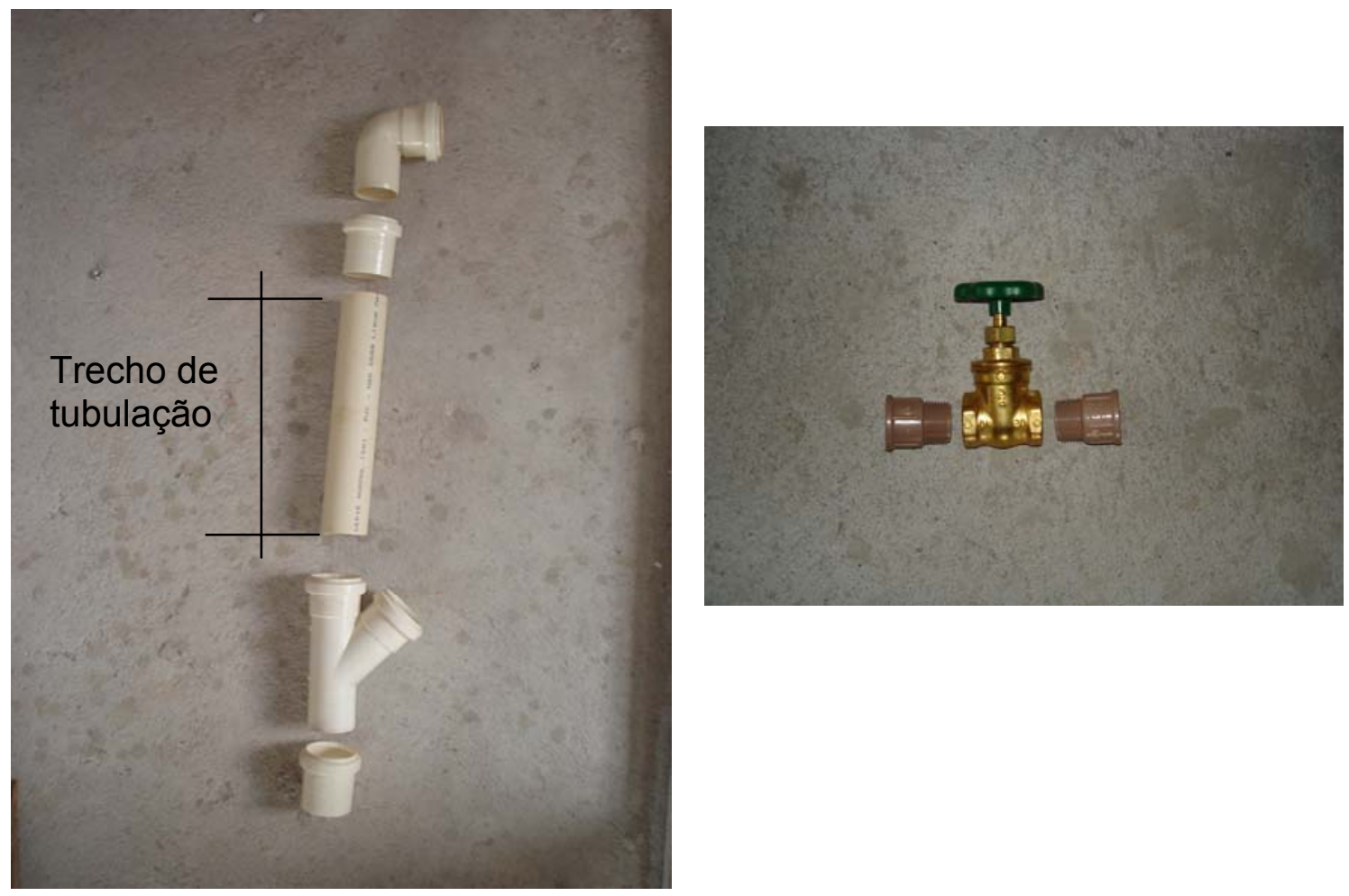

(a)

(b)

Figura 4.6 - Exemplo de trecho de tubulação com mais de uma conexão em uma de suas extremidades: (a) tubo de esgoto sanitário delimitado por duas conexões em cada extremidade; (b) registro de gaveta e o uso de adaptadores para junção com o trecho de tubulação

A representação destes elementos pode ser feita em planta, vistas ou até mesmo em esquema isométrico. O importante é ressaltar as conexões existentes entre cada trecho de tubulação (Figura 4.7). 


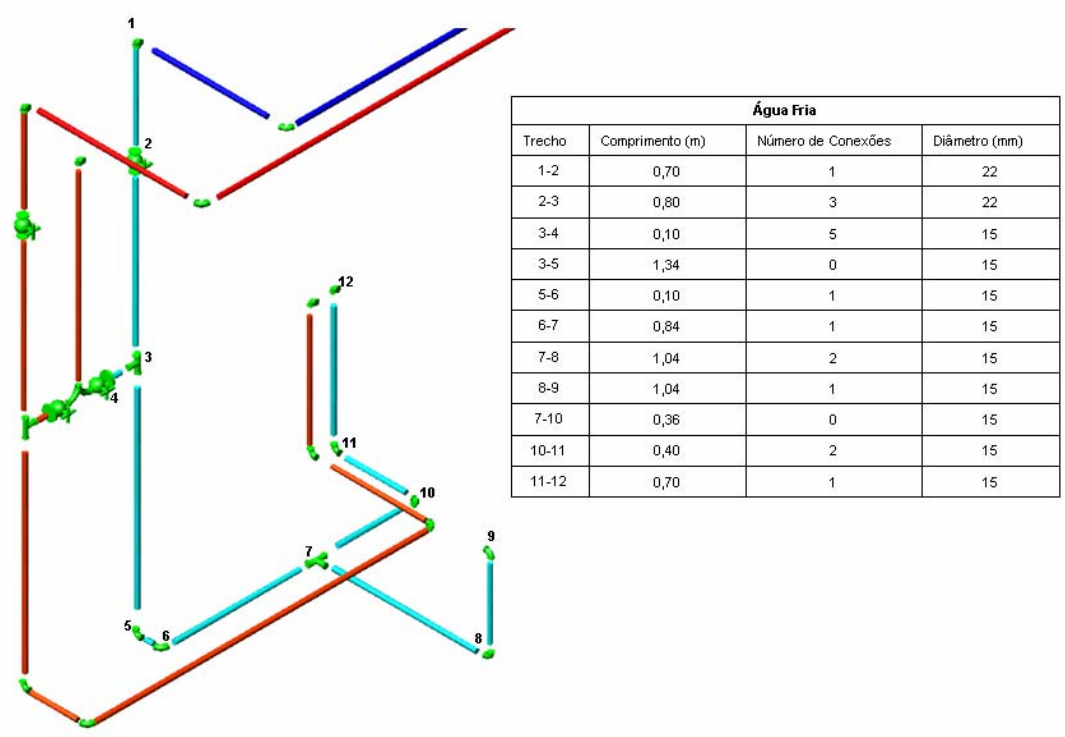

Figura 4.7 - Exemplo de isométrica com ênfase nas conexões

Este procedimento será muito útil, principalmente para a quantificação do número de conexões entre cada trecho e do número total de conexões por subsistema.

\subsubsection{Caracterização dos trechos quanto ao seu comprimento, número de conexões e diâmetro}

Após definição dos trechos de um determinado subsistema/elemento, parte-se para o levantamento das suas características, ou seja, o seu comprimento (em metros), número de conexões e diâmetro (comercial e nominal) da tubulação (em milímetros). O número de conexões é definido como o somatório de conexões presentes a montante de cada trecho de tubulação. Assim, para o exemplo ilustrado na Figura 4.7, especificamente para os ramais e sub-ramais de suprimento de água fria, obtêm-se as informações apresentadas na própria figura. 


\subsubsection{Elaboração de planilhas de dados eletrônicas primárias (Planilhas "Fonte")}

Conforme ressaltado anteriormente, a coleta de dados deve ser feita levando-se em consideração os resultados a serem alcançados e os meios de processamento destes dados.

Destaca-se aqui uma distinção na formatação destas planilhas. No primeiro conjunto de planilhas os dados são organizados em uma matriz, sendo cada linha desta matriz um registro contendo como campos (colunas), o código da obra, sistema predial, subsistema, tipo de material, forma de execução (kits ou in loco), número do trecho de tubulação, comprimento do trecho, número de conexões, diâmetro comercial e diâmetro nominal (Apêndice A).

Este conjunto servirá de base para os propósitos do levantamento do consumo unitário e produtividade da mão-de-obra. No primeiro caso, sua formatação permite que se trabalhe diretamente com recursos de Tabela Dinâmica do Excel® no sentido de se obterem os indicadores de consumo unitário de materiais. No entanto, em se tratando do levantamento da produtividade da mão-de-obra, há ainda que se reorganizar os dados de tal forma a permitir que o pesquisador consiga, em campo, ser direcionado ao local da execução dos serviços.

Para isto, destas planilhas foram obtidas outras planilhas, aqui também denominadas de fontes quanto aos propósitos do levantamento da produtividade da mão-de-obra, onde as informações características dos trechos, ou seja, as variáveis de interesse (comprimento da tubulação, número de conexões e diâmetro) foram reorganizadas formando uma matriz, na qual as linhas correspondem ao pavimento da edificação, enquanto que as colunas correspondem à identificação dos locais no pavimento-tipo em que os sistemas prediais ocorrem, partindo-se de uma identificação mais ampla (apartamento, por exemplo) até a mais específica (como a identificação de um 
determinado trecho de tubulação de um sistema predial específico de um determinado ambiente).

Desta forma são elaboradas 3 planilhas "Fonte" (ou Primárias), sendo uma associada ao comprimento do trecho, outra ao número de conexões existentes neste trecho e, finalmente, a última que diz respeito ao diâmetro nominal (Figura 4.8).

Obra:
Serviço:

\begin{tabular}{|c|c|c|c|c|c|c|c|c|c|c|}
\hline Apto & & & partam & & & & Aparta & ento " $n$ " & & \\
\hline Ambientes & & mbiente & & & te B & & te $x$ & $\mathrm{Am}$ & & \\
\hline Pav. & $1-2$ & $2-3$ & 3-4 & $4-5$ & $5-6$ & $10-11$ & $11-12$ & $20-21$ & $21 \ldots$ & $\ldots \ldots$ \\
\hline $\begin{array}{l}20 \\
19\end{array}$ & & & & & & & & & & \\
\hline$\frac{19}{18}$ & & & & & & & & & & \\
\hline ..... & $\ldots \ldots .$. & $\ldots \ldots . .$. & $\ldots \ldots \ldots$. & $\ldots \ldots \ldots .$. & $\ldots \ldots \ldots$ & $\ldots \ldots \ldots$ & $\ldots \ldots \ldots$ & $\ldots . .$. & $\ldots \ldots$ & $\ldots \ldots \ldots$ \\
\hline & & & & & & & & & & \\
\hline & & & $\ldots$ & & Lomp & ento & & & $\ldots$ & .......... \\
\hline & & 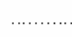 & & & - d & exõe & & $\ldots .$. & & \\
\hline & & & & & & & & & & ...... \\
\hline ..... & …... & $\ldots \ldots \ldots$. & $\ldots \ldots \ldots$ & & àmetrc & mine & nm) & & ....... & …... \\
\hline & & ................. & & $\ldots$ & $\ldots \ldots \ldots$ & $\ldots \ldots . .$. & $\ldots \ldots \ldots \ldots$ & $\ldots . .$. & & ............ \\
\hline & $\ldots \ldots$. & $\ldots$ & ........... & $\ldots \ldots \ldots$. & & .......... & ……....... & $\ldots \ldots \ldots$ & & ......... \\
\hline$\cdots$ & $\cdots$ & …….... & & & & & & & & $\cdots \cdots$ \\
\hline & & & & & & & & & & \\
\hline
\end{tabular}

Figura 4.8 - Exemplo de planilha eletrônica para a quantificação do comprimento dos trechos de tubulação, número de conexões e diâmetro

Partindo destas planilhas o pesquisador poderá organizar outras de acordo com suas necessidades de coleta. Por exemplo, ele poderá selecionar e compor um conjunto de planilhas de coleta e processamento considerando apenas os trechos que serão embutidos na parede do apartamento-tipo, com a finalidade de se obter a produtividade da mão-de-obra no corte e rasgo das paredes. O mesmo se aplica a outras situações, como a distinção entre ramais que são executados com kits ou in Ioco, entre outras. Na Figura 4.9 ilustra-se este procedimento. 


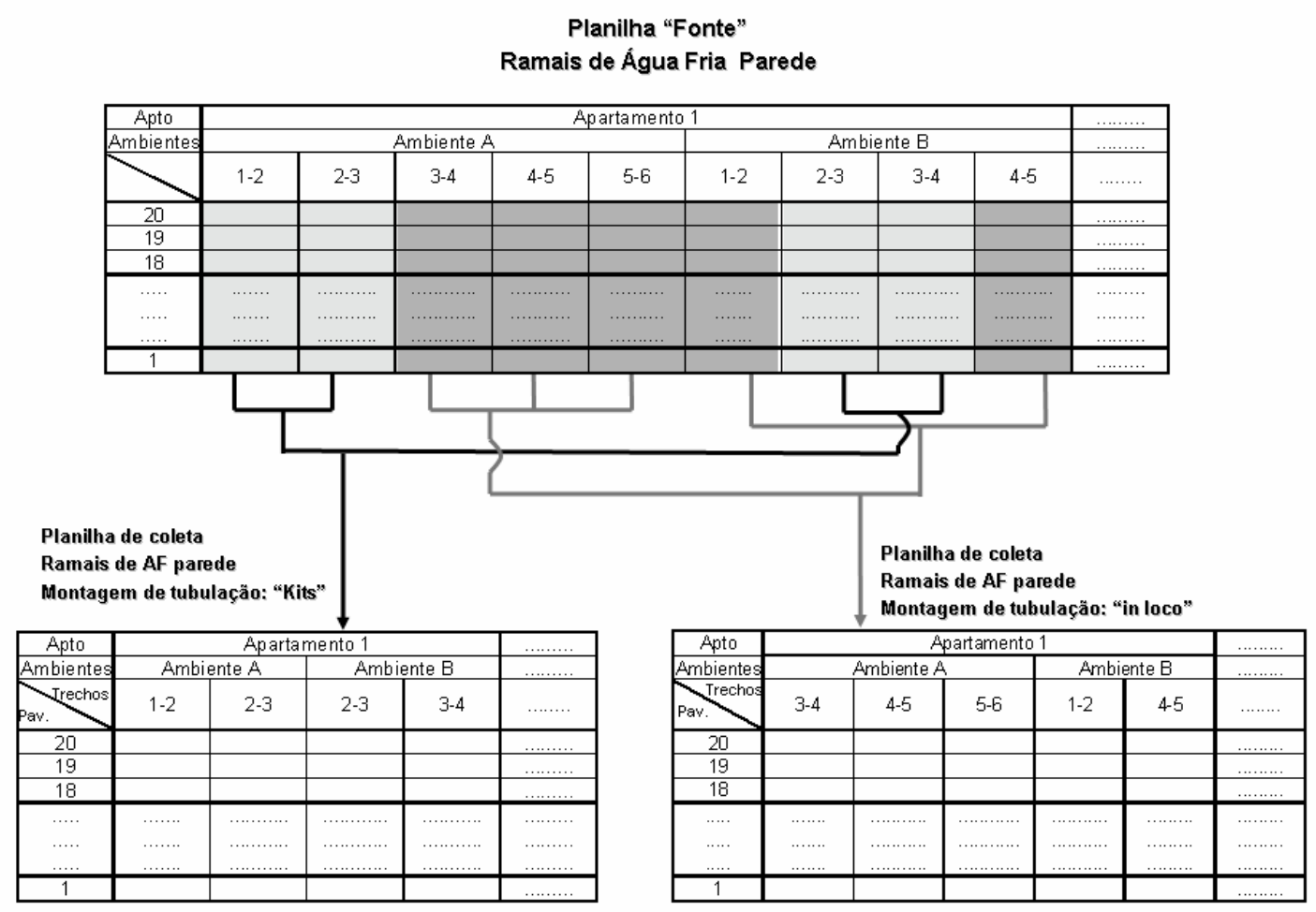

Figura 4.9 - Exemplo de elaboração de planilhas de coleta a partir das planilhas "Fonte"

Além de cumprirem o papel de fonte primária de referência de informações para a confecção de outras planilhas, elas já se constituem também em fonte de informação para o cálculo do consumo unitário de materiais, cuja associação a outros indicadores de projeto (fatores influenciadores de conteúdo) permitirá o estabelecimento dos modelos de prognóstico deste consumo.

Mais do que isto, este formato de planilha foi proposto pensando tanto no processamento das informações coletadas quanto na coleta de dados propriamente dita, na medida em que o pesquisador, ao anotar a data em que determinado trecho de determinado pavimento-tipo foi executado, automaticamente estará realizando um mapeamento dos trechos já executados em todos os pavimentos e os que ainda terão que ser executados ao longo da coleta. 
Note-se que a primeira coluna destas planilhas (Figura 4.9) representa o número dos pavimentos-tipo da edificação e, propositalmente, optou-se em representá-los na ordem em que os pavimentos são identificados no edifício, ou seja, utilizando-se uma numeração crescente dos pavimentos inferiores aos superiores.

No caso dos elementos posicionados horizontalmente (sob a laje, como é o caso dos ramais de esgoto sanitário, ramais de distribuição de água fria/quente entre outros) utilizou-se uma nomenclatura um pouco diferente para representar os pavimentos de forma a não gerar confusão no momento da coleta de dados no canteiro de obras. $\mathrm{Na}$ coluna relativa aos pavimentos são representados dois números separados por um hífen. O primeiro número indica o pavimento em que o pesquisador está pisando (piso) e o segundo o pavimento cuja laje de piso encontra-se imediatamente acima da tubulação.

Por exemplo, a notação “3 - 4" nesta coluna indica que o pesquisador está coletando dados dos ramais de esgoto sanitário relativo ao $4^{\circ}$ pavimento-tipo, ou seja, cujas tubulações passam sob a laje de teto do $3^{\circ}$ pavimento ou sob o piso do $4^{\circ}$ pavimento.

No Apêndice B apresenta-se um exemplo de Planilha de coleta de dados derivada de uma planilha "Fonte" para o caso da montagem de tubulações de ramais de esgoto sanitário sob o teto.

\subsubsection{Divisão dos serviços em tarefas e subtarefas}

Além da divisão dos sistemas prediais em suas partes (subsistemas, elementos e componentes), o que atende perfeitamente ao estudo do consumo unitário de materiais, em se tratando do estudo da produtividade da mão-de-obra há que se pensar também no processo de execução destes sistemas. Tomando-se como exemplo a execução das prumadas de água quente (para o caso de se ter um sistema 
de aquecimento central coletivo), além da atividade de montagem da tubulação, outras atividades devem ser executadas para sua finalização, como, por exemplo, a fixação destas tubulações e a colocação de isolante térmico.

Este procedimento consiste em dividir o serviço em diversos níveis, ou seja, em suas respectivas tarefas e subtarefas. Assim, os indicadores de produtividade são preferencialmente atrelados às subtarefas, considerando-se que, a partir do entendimento das partes estar-se-á entendendo o todo. Esta divisão foi baseada no método executivo destes sistemas prediais e que pode ser resumido nas figuras 4.10 , 4.11 e 4.12, apresentadas na seqüência. Salienta-se que estas figuras representam um esquema genérico da execução destes sistemas prediais, podendo haver diferenças, dependendo da postura adotada em cada obra e de detalhes particulares de concepção de cada um (por exemplo, há casos em que os ramais nas paredes não são embutidos nas mesmas, ficando rente as mesmas e encobertos posteriormente por carenagens; não necessitando do corte e rasgos das paredes).

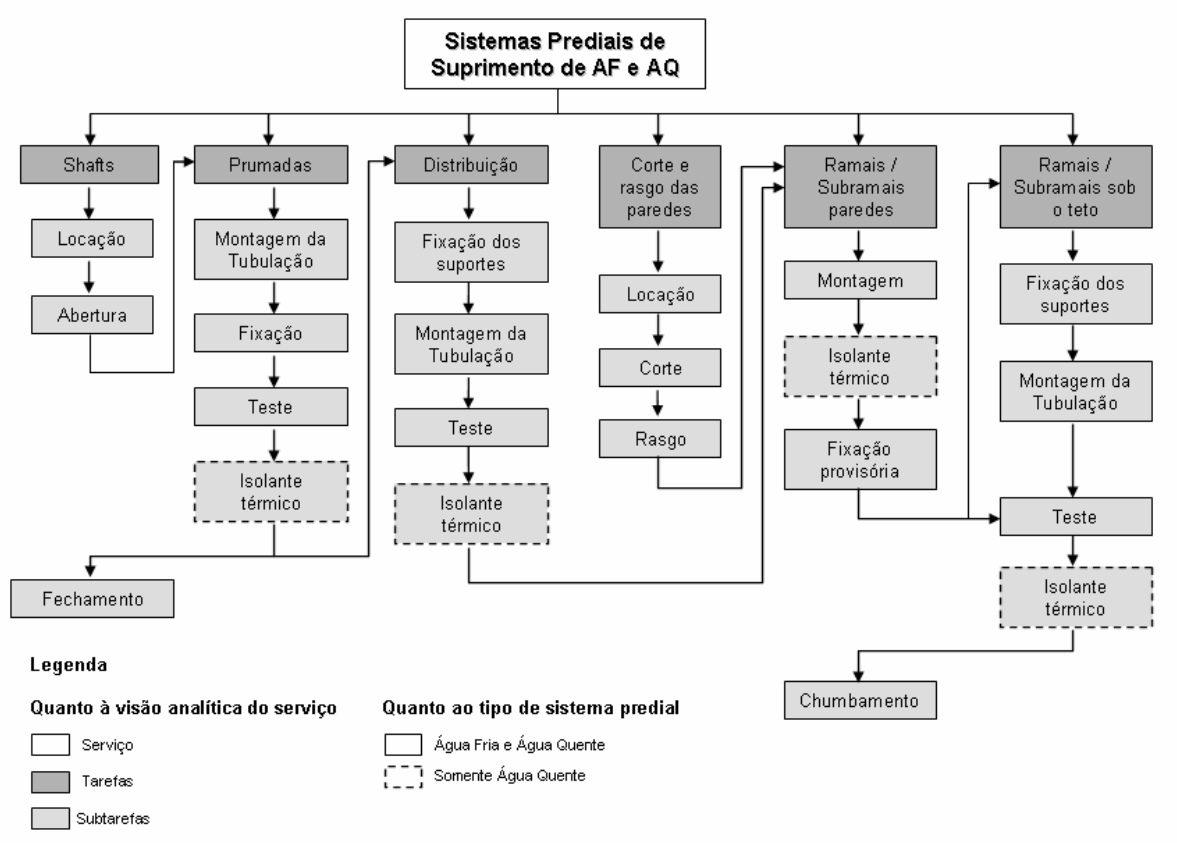

Figura 4.10 - Divisão da execução dos sistemas de suprimento de água fria e água quente em tarefas e subtarefas 


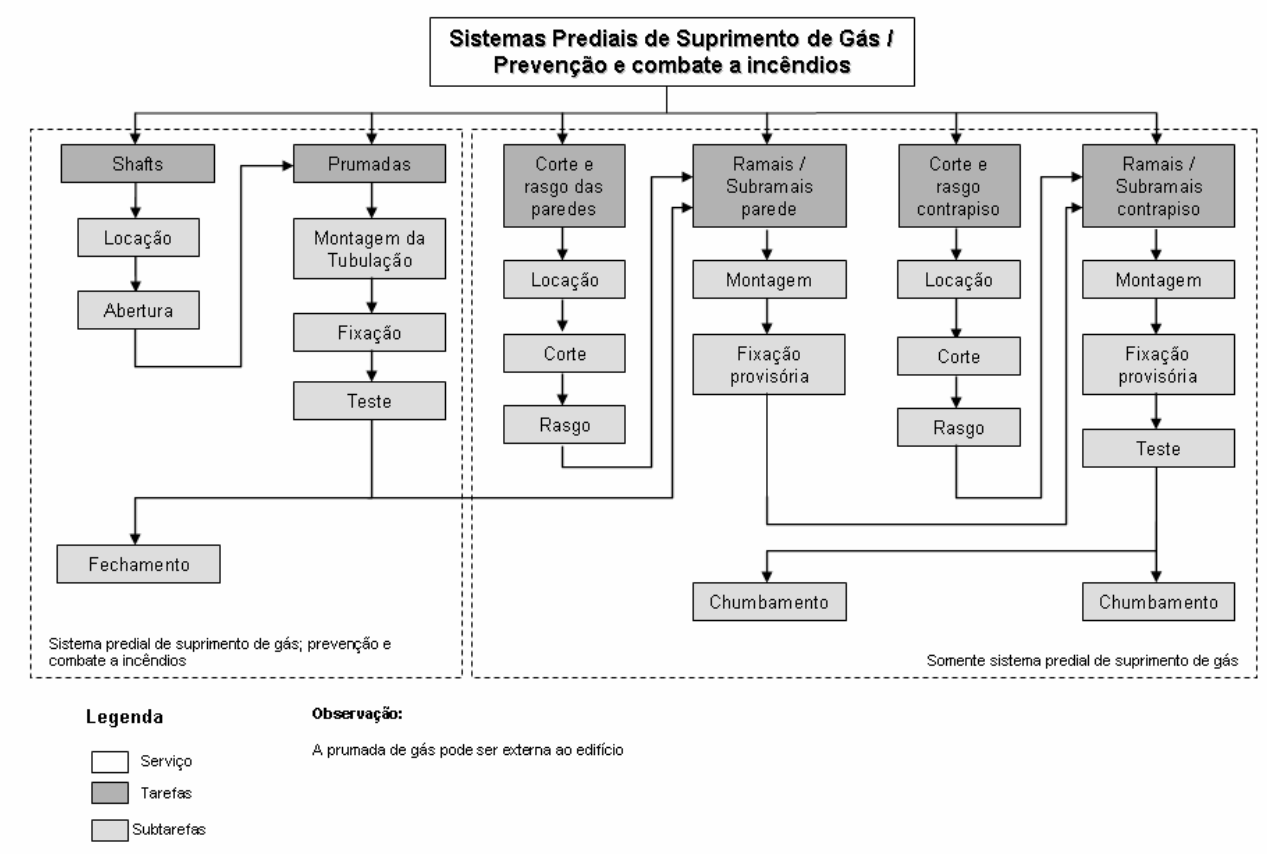

Figura 4.11 - Divisão da execução dos sistemas de suprimento gás e prevenção e combate a incêndios em tarefas e subtarefas

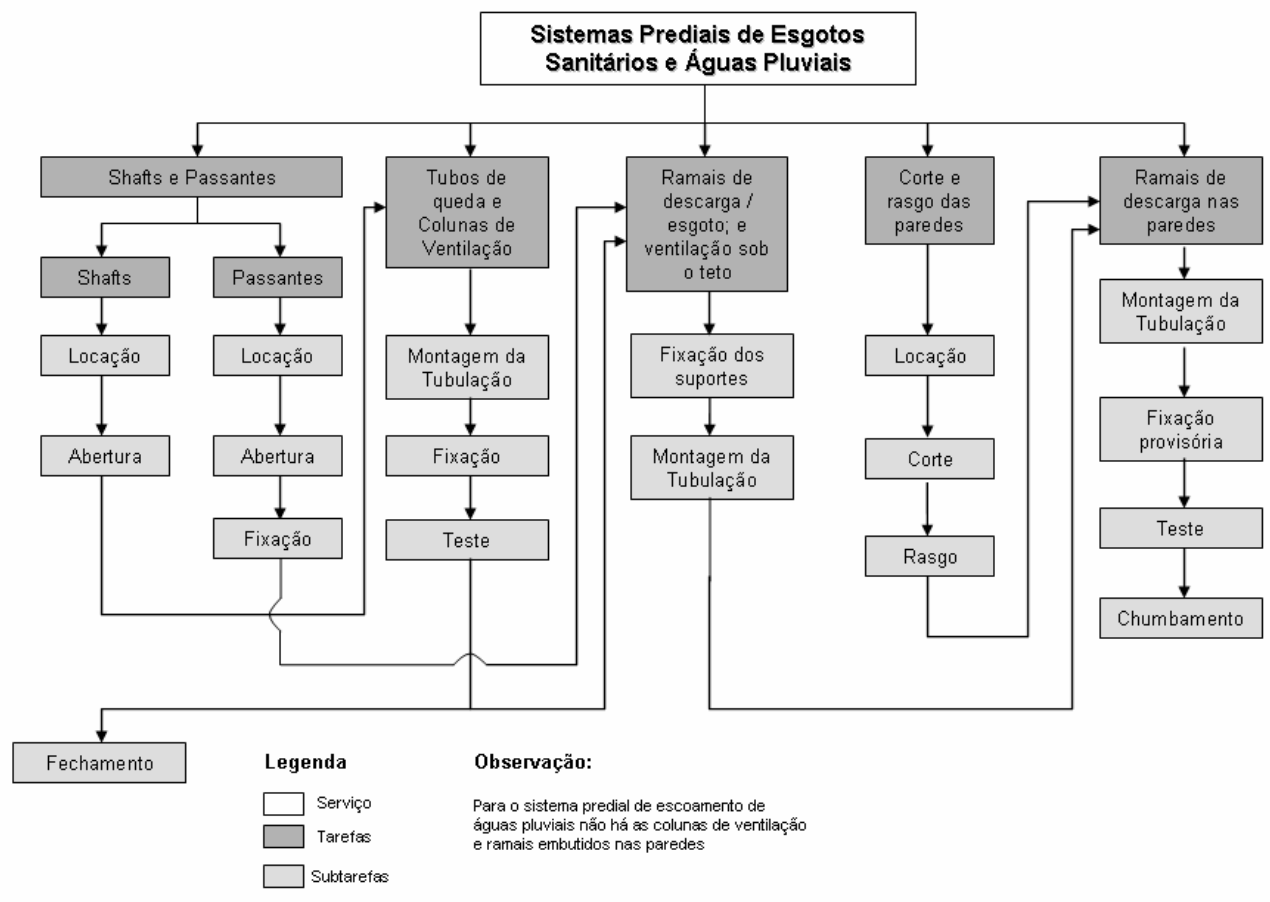

Figura 4.12 - Divisão da execução dos sistemas de esgoto sanitário e águas pluviais em tarefas e subtarefas 
Embora a obtenção dos indicadores de produtividade da mão-de-obra ao nível das subtarefas seja mais interessante, nem sempre é possível realizar este procedimento com precisão, pois isto depende da forma como a execução dos serviços está organizada.

Tomando-se como exemplo a execução dos ramais de esgoto sanitário, que podem ser decompostos nas subtarefas "Montagem das tubulações" e "Fixação das tubulações", os indicadores de produtividade da mão-de-obra para estas subtarefas são de fácil obtenção quando estas forem executadas em momentos distintos (primeiro faz-se a montagem da tubulação e, somente num segundo momento, faz-se a fixação desta na laje), ao contrário da situação em que as duas subtarefas são executadas simultaneamente (faz-se a fixação da tubulação imediatamente após sua montagem).

Em não se tendo a distinção do tempo demandado pelo operário em cada subtarefa, obtém-se, então, o indicador de produtividade relacionado a um nível superior, no caso, a tarefa, com a indicação de que tal número abrange tanto a montagem da tubulação quanto sua fixação.

Esta é a grande dificuldade em se obterem indicadores de produtividade da mão-deobra no nível das tarefas e subtarefas ou, na sua forma mais específica, ao nível das operações (Por exemplo: produtividade da mão-de-obra no corte dos tubos versus produtividade da mão-de-obra na montagem da tubulação).

Portanto, deve-se estabelecer um limite mínimo de subdivisão aceitável que atenda, ao mesmo tempo, aos propósitos de orçamentação e aos propósitos de controle da produtividade da mão-de-obra durante a execução de um determinado serviço. 


\subsubsection{Entendimento da forma de organização da produção}

Outro aspecto importante relacionado ao planejamento da coleta, que de certa forma deriva do item apresentado anteriormente, consiste em saber com o encarregado da execução dos sistemas prediais como a equipe será organizada e como cada parte dos sistemas prediais será executada.

Esta informação é muito importante, pois a partir dela, e somada às outras informações de projeto, podem-se elaborar planilhas de coleta de dados relativas à quantificação dos serviços no canteiro de obras, conforme já exemplificado no item 4.3.5.

Mais do que confeccionar estes instrumentos de coleta, o pesquisador deverá estabelecer um procedimento de coleta de informações de acordo com a estratégia de execução adotada, principalmente no que diz respeito à quantidade de homens-hora demandada na execução das tarefas e subtarefas.

$\mathrm{Na}$ medida em que se busca relacionar os homens-hora demandados na execução destas tarefas/subtarefas, isto se torna mais fácil quando o encarregado designar um operário ou uma equipe de operários para realizar uma única tarefa/subtarefa durante o dia de trabalho ou com duração definida através de marcos significativos (até a hora do almoço ou após o almoço etc.).

No entanto, pode-se deparar com uma situação muito desfavorável à obtenção destas informações como, por exemplo, a adoção da estratégia na qual os operários, durante o dia de trabalho, executam, simultaneamente ou seqüencialmente, todos os sistemas prediais de um ambiente somado ao agravante de que os componentes empregados no sistema de suprimento de água fria e quente, por exemplo, sejam de materiais diferentes (cobre para água quente e PVC para água fria). 
Nestes casos, o pesquisador deve utilizar-se de artifícios para obter as informações da forma mais precisa possível, como solicitar à mão-de-obra para anotar com giz, nas próprias vedações dos ambientes, os horários de início e fim de cada tarefa ou subsistema executado ou, até mesmo, em formulários específicos para tal.

Por todos estes aspectos justifica-se a preocupação em se conhecer previamente as condições de execução destes sistemas, além da constituição e funções de cada integrante da equipe executora, de acordo com a primeira diretriz apresentada no item 4.1.2.

\subsubsection{Elaboração de planilhas de coleta de dados no canteiro de obras}

De posse das planilhas "Fonte" e conhecida a forma como os sistemas prediais serão executados, parte-se para a elaboração dos instrumentos de coleta de dados que, no caso, serão representados por planilhas eletrônicas impressas e procedimentos (roteiro) para registro fotográfico no canteiro de obras.

\subsubsection{Quantidade de serviço executado}

As planilhas relacionadas às quantidades de serviços deverão ser elaboradas de acordo com a relação de serviços que estão e serão executados no período previsto de coleta.

A partir das planilhas "Fonte", o pesquisador deverá elaborar as planilhas de coleta, divididas em duas categorias: Quantitativo de Projeto e Coleta em Obra (Figura 4.13). A primeira categoria é composta por 3 planilhas, de mesmo formato, diferindo apenas na informação a ser inserida em cada uma: comprimento do trecho, número de conexões e diâmetro. A segunda categoria de planilhas se resume apenas a uma, 
também de mesmo formato das planilhas da categoria anterior, na qual o pesquisador deverá anotar na coluna correspondente ao trecho executado e na linha correspondente ao pavimento em execução a data de execução deste. Um exemplo destas planilhas pode ser visualizado no Apêndice $B$, para o caso dos ramais de esgoto sanitário sob o teto (montagem).

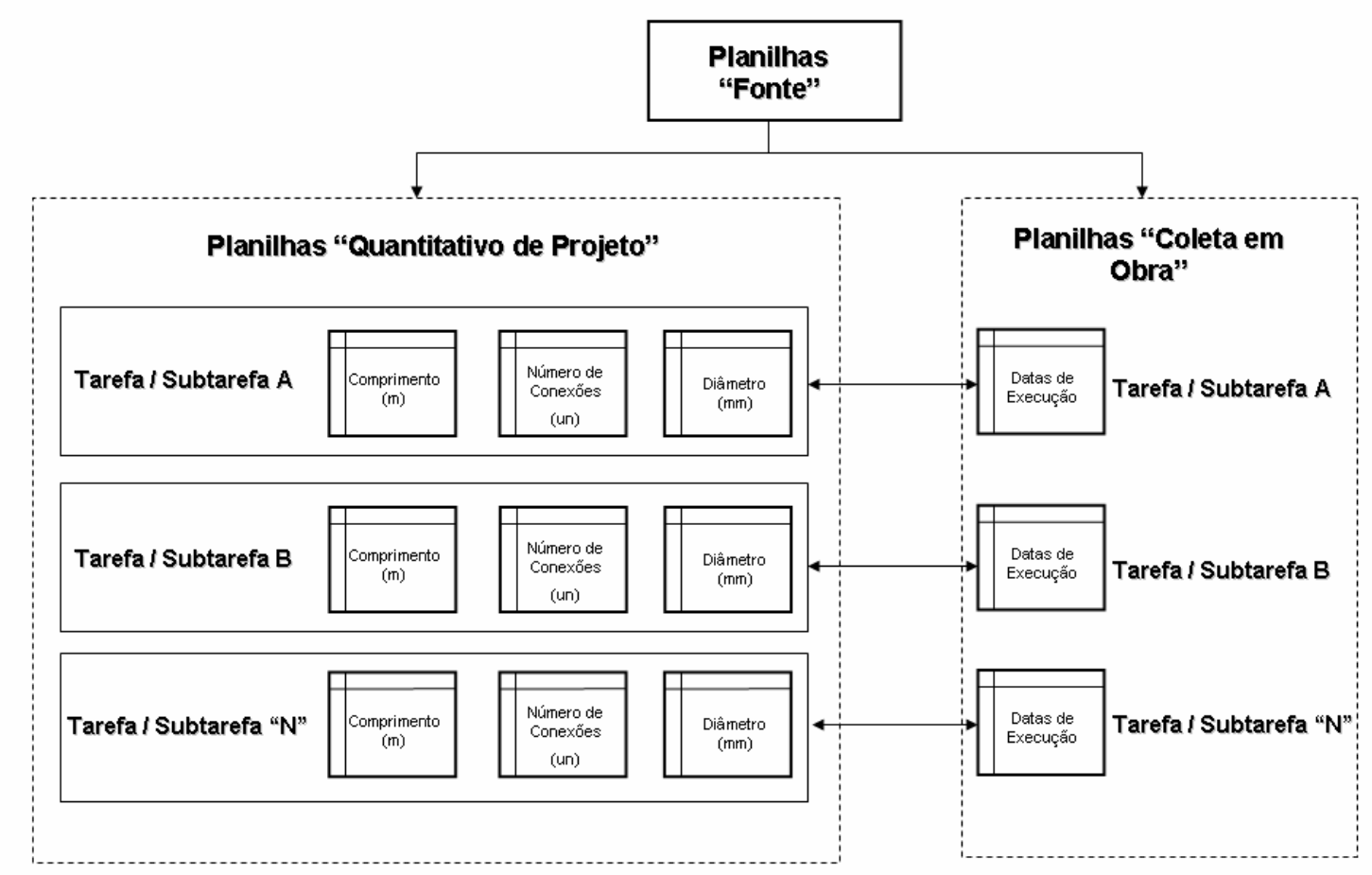

Figura 4.13 - Esquema geral das planilhas para quantificação dos serviços executados no canteiro de obras

Evidentemente, a necessidade ou não das planilhas relativas ao número de conexões e ao diâmetro associados aos trechos de tubulações dependerá do tipo de tarefa/subtarefa analisada. Assim, haverá situações em que tais informações não serão necessárias, como é o caso da tarefa "Cortar paredes".

Para facilitar a coleta de dados, no verso de cada planilha de coleta deve ser impresso o desenho (planta, vista ou perspectiva) referente à tarefa/subtarefa em questão (vide verso da planilha de Coleta em obra apresentada no Apêndice B). 
Finalmente, o pesquisador não necessita levar para o canteiro de obras todo o conjunto de planilhas relacionadas a uma tarefa ou subtarefa, sendo essencial apenas a planilha na qual se deve anotar a data em que determinado trecho de determinada tarefa/subtarefa foi executado, ou seja, a planilha de Coleta em Obra, além da relacionada à coleta dos homens-hora demandados, objeto de discussão do próximo item.

Ressalta-se novamente que, por questões de processamento de dados, as planilhas elaboradas para cada tarefa/subtarefa deverão ter o mesmo formato (mesmo número de colunas e linhas) e as colunas deverão possuir o mesmo cabeçalho. Caso contrário haverá erro no processamento das informações para o cálculo da produtividade da mão-de-obra.

\subsubsection{Homens-hora demandados para a execução dos serviços}

Os valores de produtividade da mão-de-obra serão calculados diariamente. Portanto, há várias possibilidades de composição de planilha com o objetivo de coletar a quantidade de homens demandada na execução de determinado serviço, conforme divisão deste em suas respectivas tarefas e subtarefas, durante o dia de trabalho, assim como a quantidade de horas demandadas nesta execução.

Optou-se por elaborar uma planilha que privilegiasse a facilidade de preenchimento e, ao mesmo tempo, que representasse as várias atividades executadas pelos operários durante o dia de trabalho.

Para atender a estes requisitos a planilha traz em seu corpo as subdivisões dos serviços nas suas respectivas tarefas e subtarefas, restando ao pesquisador apenas a marcação diária das horas (marcação com "X" nas respectivas colunas) em que cada operário se ocupou com a sua execução (Figura 4.14). 


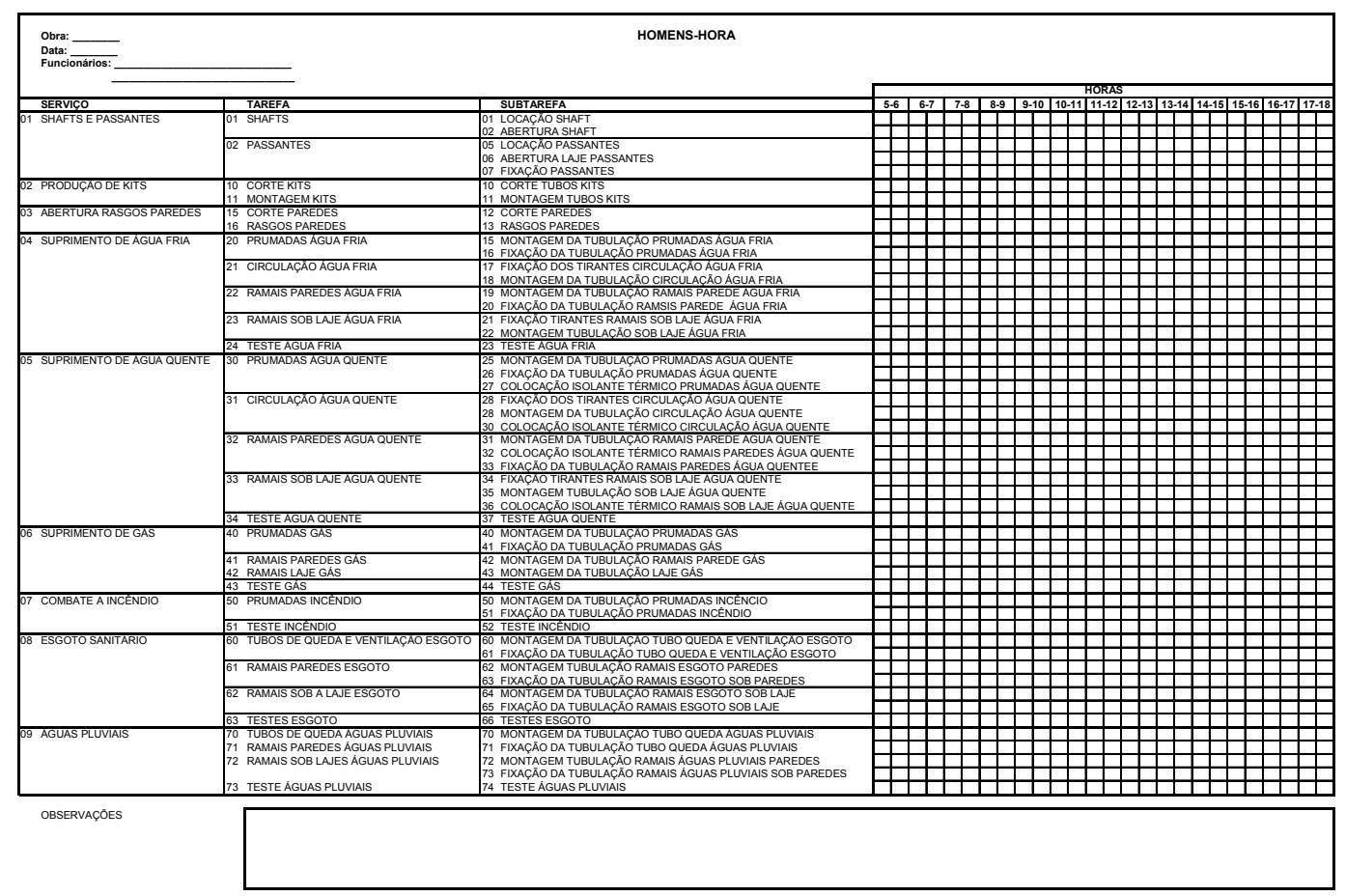

Figura 4.14 - Exemplo de planilha para anotação do serviço ou suas respectivas tarefas e subtarefas durante o dia de trabalho

Nesta planilha também há um campo destinado às observações importantes de ordem de organização do trabalho como, por exemplo, a execução de determinada atividade sob o regime de tarefa; ou relacionadas à maior ou menor dificuldade de realização dos serviços (dia chuvoso; operário adoecido, descontente entre outros aspectos). Tais informações são importantes para a explicação de possíveis variações da produtividade da mão-de-obra entre os dias observados.

\subsubsection{Caracterização da edificação e dos sistemas prediais}

Além das informações necessárias ao cálculo dos indicadores, há que se coletar também informações relativas aos possíveis indicadores influenciadores destes indicadores. 
Estes fatores estão relacionados tanto às condições de execução dos serviços quanto a questões de concepção de projeto dos sistemas (tipo de material, por exemplo) e até mesmo a questões de arquitetura da edificação (número de ambientes molháveis, por exemplo).

Alguns dos fatores já estão contemplados nas planilhas de quantificação dos serviços, como é o caso do número de conexões e diâmetro mediano, restando, portanto, abordar os outros fatores, relacionados, principalmente, às características destes sistemas e à arquitetura da edificação.

Visando esta caracterização, elaborou-se um conjunto de planilhas, as quais podem ser encontradas no Apêndice C.

\subsection{Coleta de dados}

Cabe, neste momento, uma distinção entre a coleta de dados para o cálculo do consumo unitário e a coleta de dados para o cálculo da produtividade da mão-de-obra. No primeiro caso, a coleta de dados terá como principal fonte de informação o projeto e, eventualmente, o encarregado da execução ou engenheiro responsável pela obra quando houver dúvidas.

Já a coleta de dados para o cálculo da produtividade da mão-de-obra abrange não só a coleta de dados em projeto (quantidade de serviço de projeto), como também a quantidade de serviço executada diariamente e os homens-hora demandados nesta execução. 


\subsubsection{Relativa ao cálculo da produtividade da mão-de-obra}

\subsubsection{Coleta diária}

A dinâmica da coleta de dados consiste em o pesquisador visitar diariamente o canteiro de obras com o objetivo de obter tais informações, preenchendo as planilhas específicas de acordo com o serviço executado.

A experiência deste pesquisador permite afirmar que o melhor momento para se coletar estas informações é o começo da manhã, no início da execução dos serviços. Neste momento, o pesquisador deverá perguntar ao encarregado da execução qual a programação dos serviços para o dia, alocando a cada tarefa/subtarefa os funcionários da equipe. Neste momento deve-se perguntar também se algum operário estará trabalhando sob o regime de tarefa e se houve algo de anormal que pudesse ter influenciado a produtividade da mão-de-obra do dia anterior.

Além das informações pertinentes ao dia em questão, o pesquisador deve perguntar também ao encarregado se houve alguma alteração na programação informada na manhã do dia anterior.

É comum deparar-se com situações em que o operário executará uma atividade não prevista na planilha de coleta ou que não seja de interesse como, por exemplo, descarregamento de materiais, arrumar estoque, limpeza entre outras. Nestas situações, o pesquisador deve anotar esta atividade no campo destinado às observações e, para efeito de processamento dos dados, consideram-se estas atividades como sendo "Outros Serviços".

Outra situação particular a ser observada consiste no retrabalho, ou seja, quando o operário tem que refazer o serviço já executado anteriormente, seja por ele ou por outro operário como, por exemplo, inverter a posição da prumada de gás no shaft, 
realinhar os ramais de água fria e água quente já chumbados nas paredes em função da espessura do revestimento etc ${ }^{27}$.

De posse destas informações, o pesquisador deverá se encaminhar para os pavimentos nos quais houve execução dos serviços no dia anterior e fazer sua quantificação, que consiste em anotar na, intersecção pavimento/trecho, a data em que este trecho foi executado, no caso, a data do dia anterior.

Ao término da coleta de dados no canteiro de obras, o pesquisador deve lançar os dados coletados diretamente na planilha eletrônica para a realização dos cálculos pertinentes.

\subsubsection{Mapeamento inicial dos serviços}

Antes de proceder à coleta diária das informações nos canteiros de obras, o pesquisador deverá fazer o mapeamento dos serviços, que consiste em anotar quais pavimentos, ambientes do pavimento e, até mesmo, trechos de determinado sistema predial em determinado ambiente de um determinado pavimento foram executados até a presente data.

Para os trechos já executados, deve-se fazer uma anotação singular indicando a sua execução, como, por exemplo, a abreviação de all correct $(\mathrm{OK})^{28}$. Visando a não ocorrência de erros, este mapeamento deve ser feito no final do dia anterior ao início da coleta de dados. Após conversa prévia com o encarregado, parte-se para os pavimentos procedendo este mapeamento, inclusive visitando pavimentos inferiores

\footnotetext{
${ }^{27}$ Neste caso, a RUP Diária será infinita, uma vez que a quantidade de serviço (denominador da equação) é igual a zero.

${ }^{28}$ A origem desta abreviação é confusa. O primeiro registro data de 1839 , quando um jornal de Boston usou esta abreviatura humoristicamente levando-se em consideração a sua pronúncia ("oll korrect") com sentido de "all correct". Outra versão se refere à marcação feita pelos soldados americanos ao voltarem para o Quartel durante a Guerra de Secessão, que terminou em 1865. Neste retorno, marcavam em um quadro a abreviação "0 k" (zero killed) para informar a não ocorrência de baixas. Com o tempo, isto passou a significar "tudo bem". Mas esta abreviação foi popularizada pelo presidente Martin Van Buren, que tentava sua reeleição em 1840. Apelidado de Old Kinderhook usou as iniciais deste apelido como slogan de campanha, aproveitando o trocadilho com o sentido de "all correct". Fonte: Revista Aventuras na História. p.22. Edição 22. Junho de 2005. Editora Abril.
} 
ao informado pelo encarregado com o objetivo de anotar possíveis trechos ainda não executados de determinados sistemas prediais em decorrência de alguma anormalidade, como a falta de material, por exemplo.

\subsubsection{Relativa ao cálculo do consumo unitário de materiais}

Ao se elaborarem as planilhas "fonte", automaticamente se estarão organizando as informações para o cálculo do consumo de materiais (tubos e conexões), bastando apenas manipular estas planilhas de tal forma a obter as informações necessárias.

Assim, caberá ao pesquisador organizar as informações que porventura ainda não estejam no formato adequado à totalização dos metros de tubos e de conexões relacionados a cada subsistema.

\subsubsection{Relativa à caracterização da edificação e dos sistemas prediais}

A coleta de dados relativos à caracterização da edificação e dos sistemas prediais deve ser feita na medida em que se avança no entendimento dos projetos. Muitas das informações podem ser obtidas diretamente com o engenheiro responsável ou com o encarregado da execução.

\subsection{Processamento dos dados}

O processamento dos dados envolve o cálculo do consumo de material por unidade de área (metros de tubos $/ \mathrm{m}^{2}$ ) e da produtividade da mão-de-obra (homens-hora por unidade de serviço), além dos fatores influenciadores destes dois indicadores. 
No caso específico do consumo unitário de materiais, conforme já ressaltado anteriormente, o processamento é simplificado na medida em que se resume na totalização de algumas variáveis de interesse (comprimento dos trechos e número de conexões) e cálculo da mediana dos diâmetros dos tubos, valores estes associados a cada subsistema.

Ao contrário deste processamento, o processamento das informações relativas à produtividade da mão-de-obra é mais complexo, pois, de acordo com a organização dos dados, há que se vincular, a partir da data anotada na planilha de "Coleta em Obra", os respectivos valores de comprimento, diâmetro e número de conexões, além dos homens-hora demandados na execução do serviço. Mais do que isto, além desta vinculação, busca-se a totalidade de metros de tubulação de uma determinada tarefa/subtarefa executada nesta data, a totalidade de conexões e o diâmetro mediano.

Tal vinculação seria mais fácil de ser realizada se as informações fossem organizadas sob a forma de registros e não sob a forma de matriz (as linhas representam os pavimentos e as colunas, na sua forma mais restrita, os trechos de tubulações). No entanto, optou-se por esta postura pela necessidade de se ter uma visão ampla da evolução dos serviços ao longo do período de coleta. Desta forma, o pesquisador inicia sua coleta de dados exatamente do ponto onde o serviço parou em datas anteriores, o que não fica claro se os dados forem organizados sob a forma de registro ${ }^{29}$.

Embora os programas de planilhas eletrônicas possuam comandos que permitam transpor os dados sob a forma de matriz para a formatação ordenada de registros, este pesquisador preferiu manter os dados sob a forma de matriz, uma vez que um ${ }^{29}$ Por exemplo, no Excel®, o registro é representado por uma linha e as colunas correspondem ao campo deste
registro. 
único comando permite fazer a vinculação das datas às variáveis de cálculo (comprimento, conexões e diâmetro).

\subsubsection{Produtividade da mão-de-obra}

Uma grande dificuldade na elaboração deste trabalho residiu no processamento das informações para a obtenção dos valores da quantidade diária de serviço realizado, número de conexões e diâmetro mediano relacionado a cada dia de coleta. Esta dificuldade foi amenizada com a utilização de fórmulas matriciais, um recurso existente no Microsoft Excel $®$.

Estas fórmulas matriciais agem sobre dois ou mais conjuntos de valores, sendo que cada conjunto constitui um argumento matricial. No entanto, para que se tenha sucesso na aplicação destas fórmulas matriciais, os argumentos matriciais precisam ter o mesmo número de linhas e colunas. Na Figura 4.15, a seguir, exemplifica-se o que venha a ser argumento matricial, utilizando-se como variáveis os dados de projeto relacionados aos trechos de tubulação. 


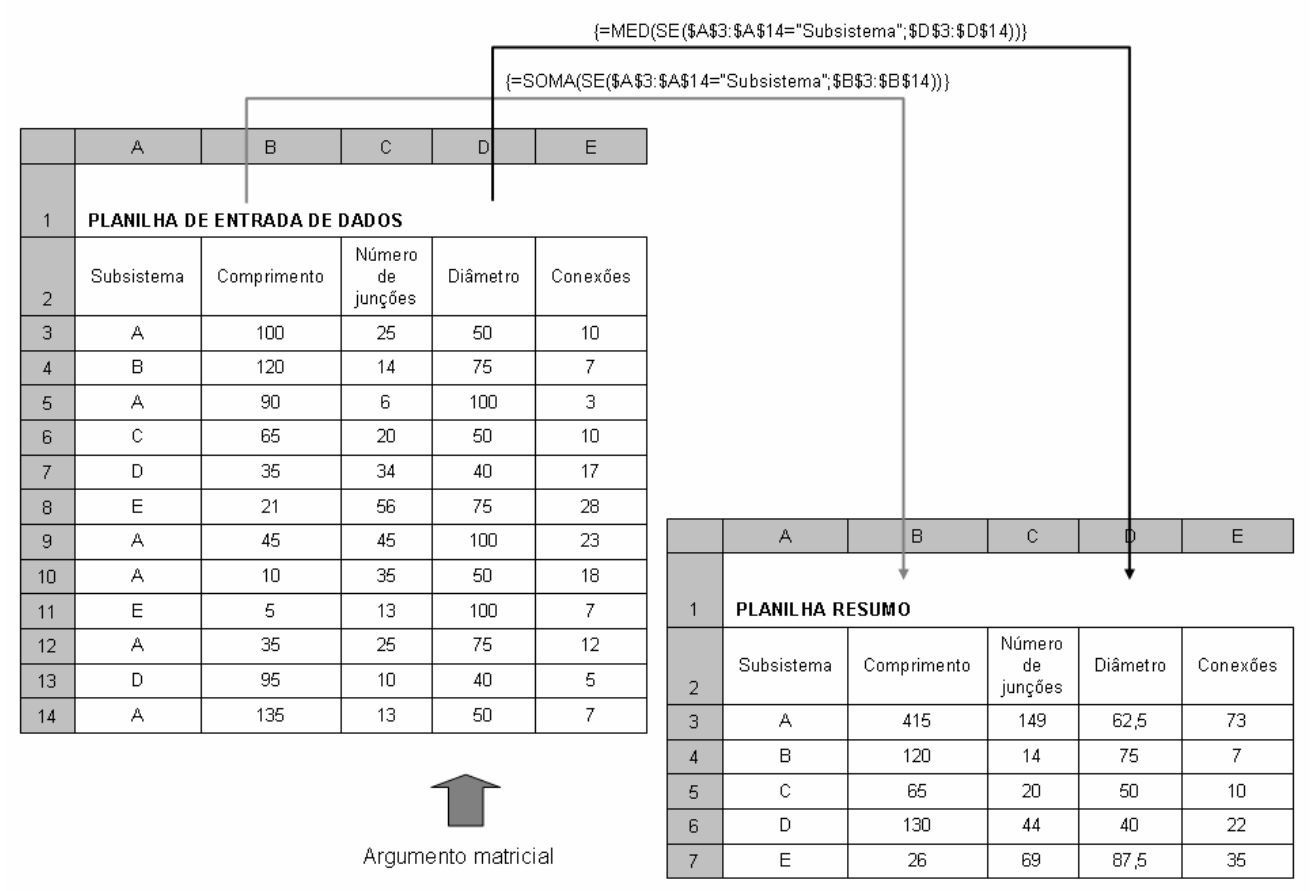

Figura 4.15 - Exemplo de utilização de argumentos matriciais no processamento dos dados

Cada coluna da planilha representada nesta figura constitui um argumento matricial, ou seja, o "Subsistema", o "Comprimento", o "Diâmetro" e o "Número de Conexões", que são representados, respectivamente, pelos seguintes conjuntos de células: “A3:A14”; “B3:B14”; “D3:D14” e "E3:E14”.

Cada célula de um argumento está diretamente associada à célula com o mesmo número de linha em outro argumento como, por exemplo, (“A1 e D1”); (“A4 e E4") e assim sucessivamente.

Para se calcular, por exemplo, o somatório do comprimento de tubulação do Subsistema "A" seria necessário utilizar a função "SOMA" e relacionar o argumento matricial que representa os subsistemas (delimitado pelas células "A3:A14") ao argumento matricial que contém o comprimento de tubulação de cada subsistema (delimitado pelas células "B3:B14"). 
Utilizando a função "SE", o Microsoft Excel $®$ analisa quais células do argumento matricial "A1:A12" possuem o valor "A" e retorna os valores das mesmas linhas do campo "Comprimento" do argumento matricial delimitado pelas células "B3:B14" na função "SOMA" (Vide Planilha Resumo na Figura 4.15).

No entanto, ao final da composição de cada fórmula, deve-se selecioná-la com o auxílio do mouse e, em seguida, pressionar as teclas shift + control + enter. Este procedimento fará com que a fórmula seja delimitada por chaves, ponto essencial para que o processamento seja realizado.

Este mesmo raciocínio pode ser aplicado aos demais argumentos matriciais e, inclusive, utilizando-se outras funções, como a mediana ou média, por exemplo.

Para o caso do cálculo da produtividade da mão-de-obra, do número de conexões, do comprimento mediano de tubulação, diâmetro mediano e outras informações de interesse, o argumento matricial não se resumiu apenas na coluna, e sim na matriz (linha $\mathrm{x}$ coluna) presentes em pastas de trabalho diferentes, tornando este procedimento um pouco mais complexo.

$\mathrm{Na}$ Figura 4.16 apresenta-se um fluxograma no qual se identifica de onde as informações foram extraídas para a obtenção da "Planilha Resumo Final" relacionada a cada tarefa/subtarefa, que congrega, além dos valores de produtividade da mão-deobra, alguns fatores de conteúdo potencialmente influenciadores. 


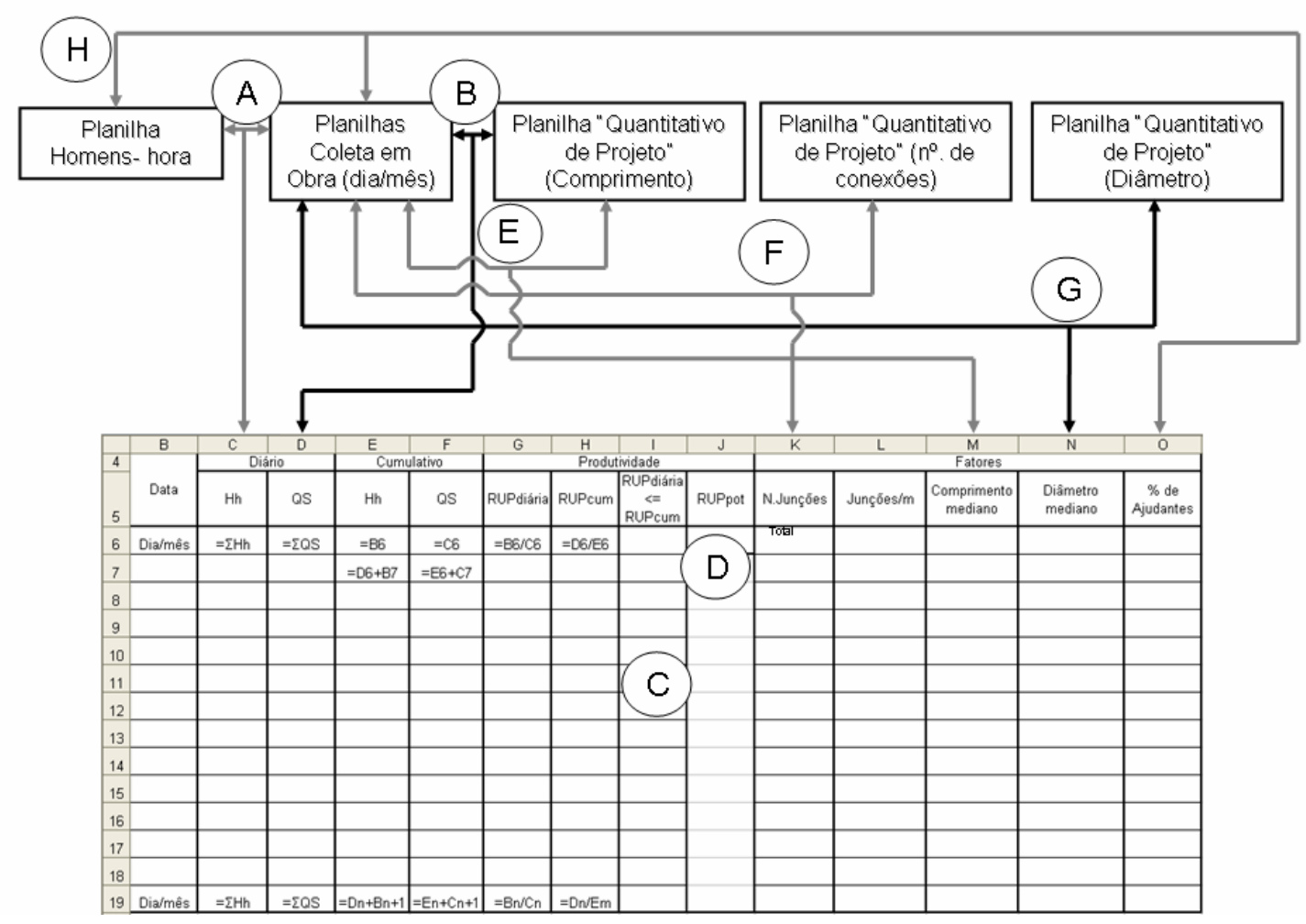

Figura 4.16 - Fluxograma para obtenção do indicador de produtividade da mão-de-obra a partir das planilhas "Fonte", "Coleta em Obra" e de "Quantitativo de Projeto"

A relação "A", indicada na figura, envolve os argumentos matriciais "Data de Execução", "Homens-hora" da Planilha "Homens-hora" e "Data de Execução" da Planilha "Coleta em Obra", com o objetivo de se obter a totalização de Homens-hora demandados para a execução de determinada tarefa/subtarefa em cada dia.

As relações "B", "F”, "E" e "G" envolvem o argumento matricial "Data de Execução" da Planilha "Coleta em Obra" com os argumentos matriciais "comprimento", "número de conexões" e "diâmetro" pertencentes às planilhas "Quantitativos de Projeto" com a finalidade de se obter a totalização do comprimento de tubulação e número de conexões e a mediana do diâmetro e comprimento para cada tarefa/subtarefa analisada. 
Note-se que em algumas colunas da tabela apresentada nesta figura contém as fórmulas gerais para o cálculo da RUP Diária e RUP Cumulativa. A RUP Potencial (representada pela letra "D" na figura) é calculada fazendo-se a mediana das RUP's Diárias menores ou iguais à RUP Cumulativa (letra "C" da figura), conforme definições apresentadas no capítulo 2 .

\subsubsection{Consumo unitário de materiais}

Em comparação ao processamento dos dados para obtenção dos indicadores de produtividade da mão-de-obra, o processamento dos dados para o cômputo do consumo unitário de materiais é simples, bastando ao pesquisador utilizar comandos básicos do Microsoft Excel®. A Figura 4.17 traz um fluxograma de como os resultados do consumo unitário são obtidos.

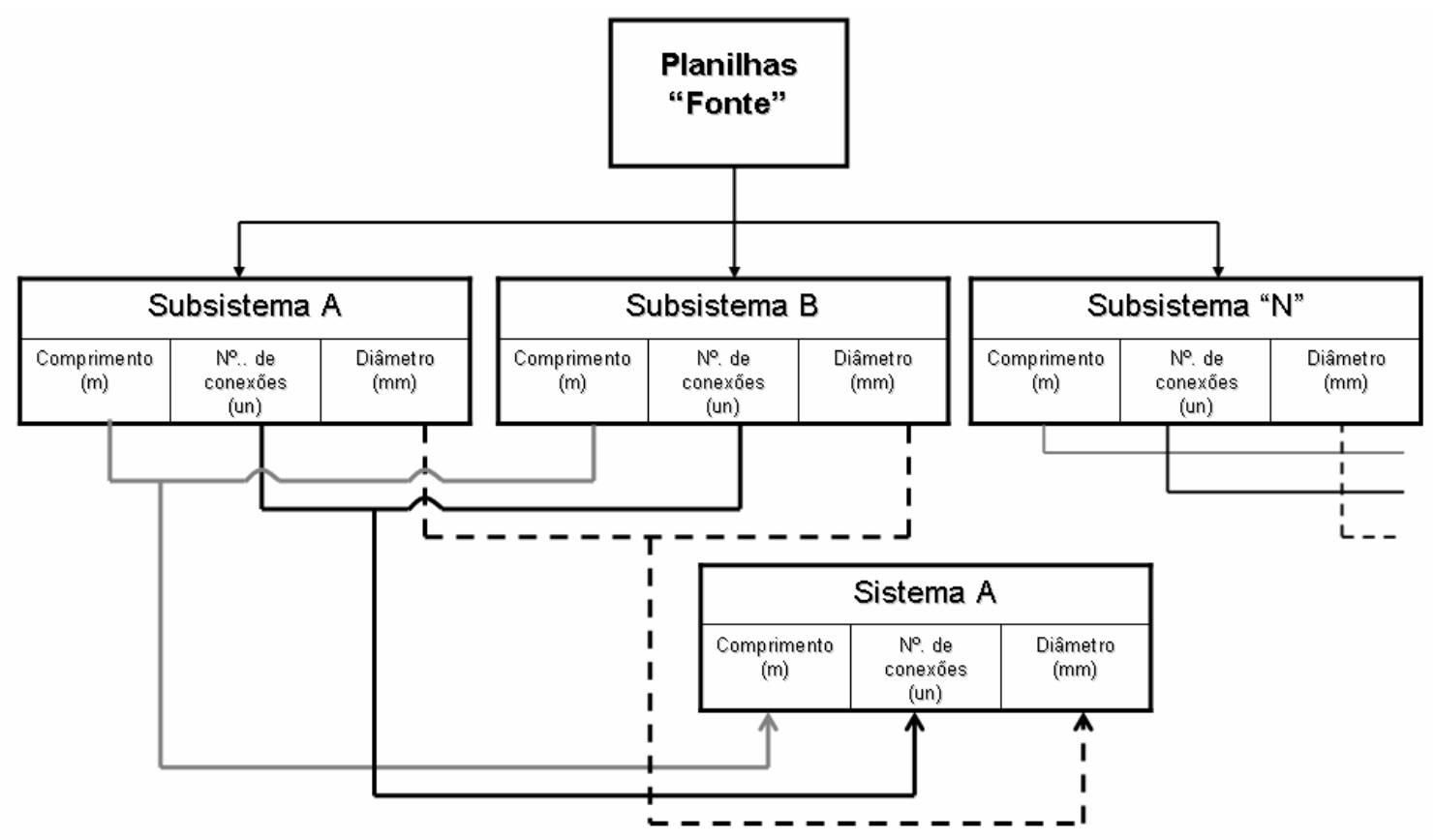

Figura 4.17 - Fluxograma para a obtenção do consumo unitário a partir das planilhas "Fonte" 


\subsubsection{Caracterização da edificação e dos sistemas prediais}

Finalmente, o processamento das informações relacionadas à caracterização da edificação e dos sistemas prediais é o mais simplificado de todos, uma vez que muitas se resumem na consideração de qual característica representa o sistema ou a informação da edificação pertinente ao entendimento dos indicadores de produtividade da mão-de-obra ou consumo unitário de materiais. 


\section{Capítulo 5}

\section{ESTUDOS DE CASO}

Neste capítulo é dada ênfase aos Estudos de Caso realizados no que diz respeito ao levantamento da produtividade da mão-de-obra e consumo unitário de materiais. São apresentadas as principais características das edificações e dos sistemas prediais empregados em cada uma. Apenas para as obras onde se realizou o estudo da produtividade da mão-de-obra, apresenta-se o método executivo, assim como a composição da equipe de trabalho encarregada da execução nestas obras (vide Tabela 1.2).

É importante ressaltar que, embora se tenha procurado abordar os aspectos considerados importantes na caracterização dos Estudos de Caso, sua complementação pode ser feita consultando-se o Anexo A, no qual foram transcritas as principais partes dos projetos das obras, uma vez que seria inviável anexar os projetos na sua totalidade. Neste anexo podem ser visualizados, para cada obra, além da planta do pavimento-tipo, o detalhamento dos sistemas prediais em cada ambiente, além de um esquema vertical simplificado do sistema predial de suprimento de água fria elaborado a partir dos projetos originais. 


\subsection{Características gerais dos Estudos de Caso}

Neste item são apresentadas as principais características das obras analisadas no que diz respeito, principalmente, a sua arquitetura, sistemas prediais empregados, método executivo e composição das equipes responsáveis pela execução dos sistemas das obras onde se realizou o levantamento da produtividade da mão-de-obra.

\subsubsection{SP0101}

Trata-se de um conjunto residencial de alto padrão composto por duas torres de 20 pavimentos, sendo dois subsolos, um pavimento térreo/mezanino, 16 pavimentos-tipo (com dois apartamentos por pavimento), cobertura e ático, onde se localizam dois reservatórios de água, casa de máquinas dos elevadores separando estes dois reservatórios e bomba de incêndio. A vista geral desta obra pode ser observada na Figura 5.1.

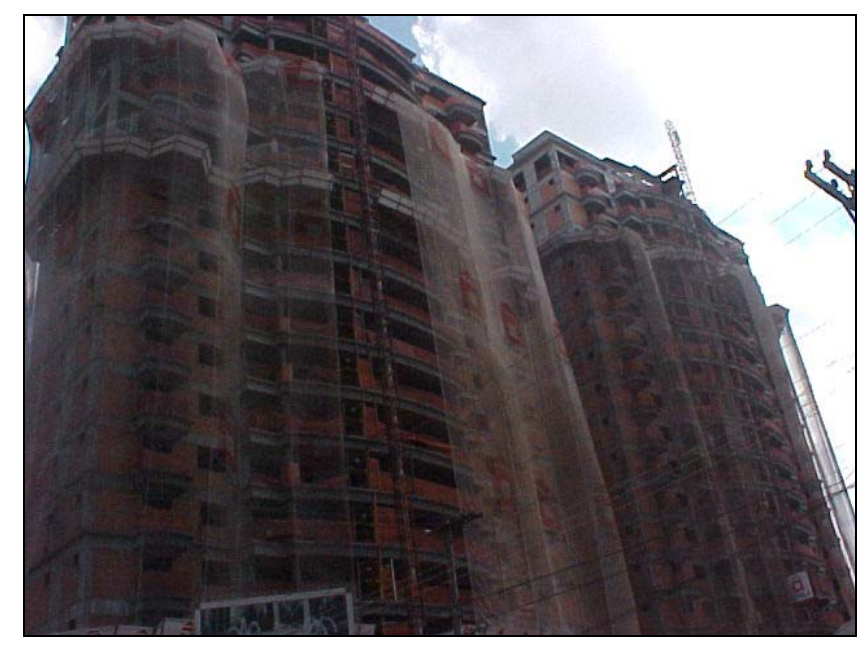

Figura 5.1 - Vista Geral da obra SP0101

A estrutura reticulada de concreto armado moldado in loco foi concebida em laje maciça. Sua vedação é composta por alvenarias de blocos cerâmicos, que serão 
revestidos internamente de gesso, nas áreas não molháveis, e argamassa, nas áreas molháveis, sendo estas últimas posteriormente revestidas com placas cerâmicas.

\subsubsection{SP0201}

A obra SP0201 consiste em um edifício residencial de alto padrão em estrutura convencional de concreto armado moldado in loco de 18 pavimentos, sendo 1 subsolo, térreo, 13 pavimentos-tipos (com dois apartamentos por pavimento) e 1 duplex, além da cobertura e ático onde estão localizados o reservatório superior, casa de máquinas dos elevadores e bomba de incêndio.

Da mesma forma que o edifício anterior, sua estrutura de concreto armado foi moldada in loco e apresenta laje maciça como elemento estrutural de superfície. As vedações são em paredes de blocos cerâmicos e receberão argamassa nas áreas molháveis e gesso liso nas demais dependências. A vista geral desta obra pode ser observada na Figura 5.2.

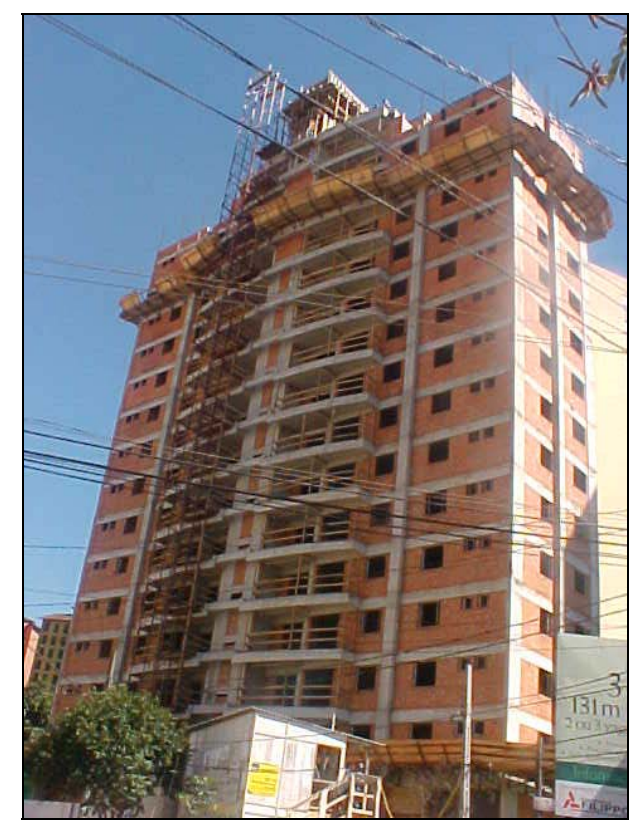

Figura 5.2 - Vista Geral da obra SP0201 


\subsubsection{SP0301}

A obra SP0301 consiste em um edifício residencial de alto padrão de 28 pavimentos, sendo 3 subsolos, pavimento térreo, 20 pavimentos-tipo com um apartamento cada e 2 pavimentos com apartamento duplex, além da cobertura e ático onde se localizam a casa de máquinas dos elevadores, bomba de incêndio e reservatório de água. Com estrutura reticulada de concreto armado moldado in loco, o edifício é vedado por alvenaria de blocos de concreto. A vista geral desta obra pode ser observada na Figura 5.3.

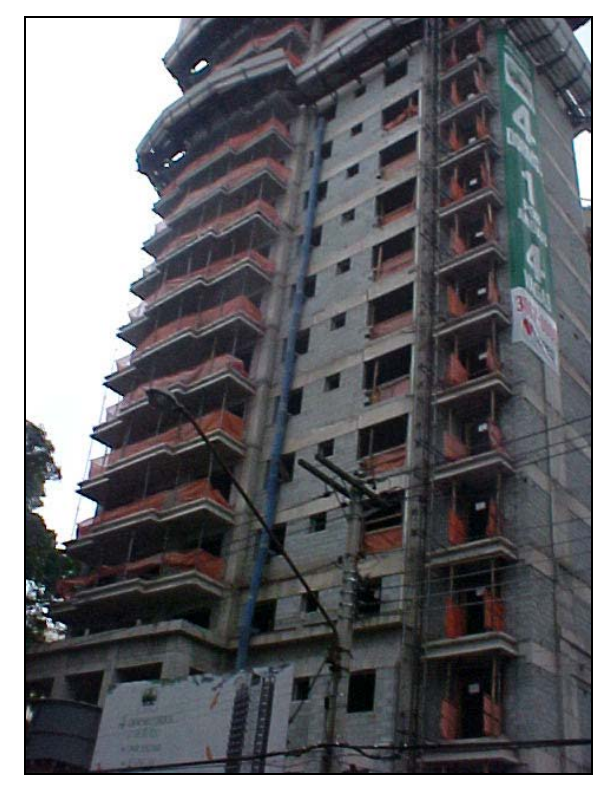

Figura 5.3 - Vista Geral da obra SP0301

\subsubsection{SP0401}

Trata-se de um conjunto residencial de médio padrão localizado no interior do Estado de São Paulo, composto por duas torres de 22 pavimentos, sendo um subsolo, pavimento, 17 apartamentos-tipo (com 4 apartamentos por pavimento), um duplex e cobertura e ático, onde se localizam o reservatório de água, casa de máquinas dos elevadores e bomba de incêndio. Como diferencial em relação às demais obras 
destaca-se o fato de a laje estrutural ser nervurada, executada com fôrmas de polipropileno.

Sua vedação é composta por alvenarias de blocos cerâmicos, que serão revestidas internamente de gesso, nas áreas não molháveis, e argamassa, nas áreas molháveis, sendo estas últimas posteriormente revestidas com placas cerâmicas.

\subsubsection{SP0501}

A obra SP0501 consiste em um edifício residencial de 22 pavimentos-tipo e 2 subsolos, além do pavimento térreo, cobertura e ático, voltado à classe média, com 4 apartamentos por andar localizado na capital paulistana. A estrutura reticulada em concreto armado moldado in loco e vedação de paredes de blocos de concreto receberão revestimento externo de argamassa e revestimento interno de pasta de gesso nas áreas não molháveis.

\subsubsection{SP0601}

Trata-se de um edifício residencial voltado à classe alta localizado na capital paulistana concebido em estrutura de concreto armado moldado in loco composto por 22 pavimentos-tipo com 1 apartamento por andar e um pavimento com apartamento duplex, 2 subsolos, térreo, cobertura e ático, onde se localizam o reservatório de água, casa de máquinas dos elevadores e bomba de incêndio (Figura 5.4). O apartamentotipo conta com um grande terraço com churrasqueira, dois dormitórios e 2 suítes. As paredes de blocos cerâmicos serão revestidas com argamassa (fachada) e pasta de gesso (ambientes internos não molháveis). 


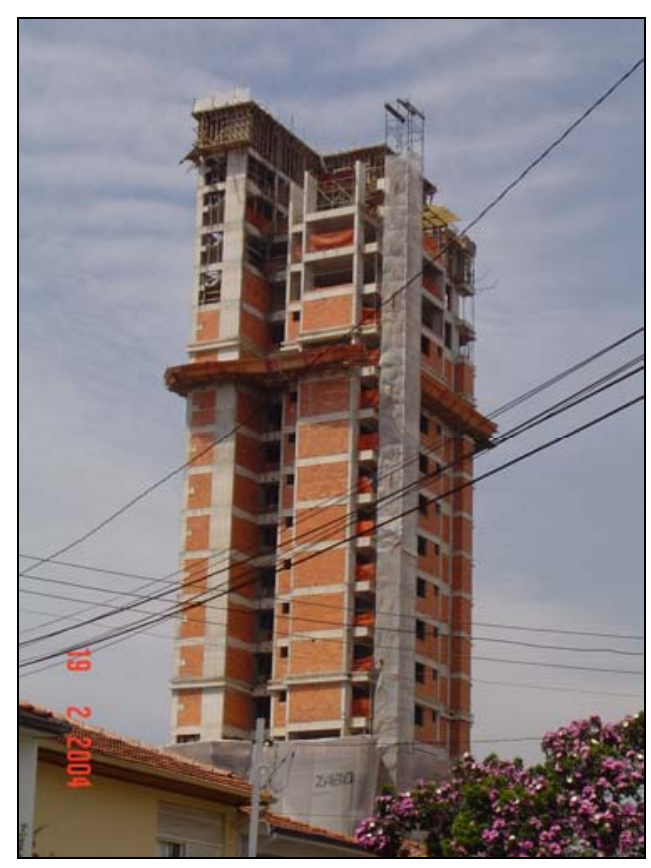

Figura 5.4 - Vista Geral da obra SP0601

\subsubsection{SP0701}

Trata-se de um edifício residencial voltado à classe média também localizado na capital paulistana composto por 13 pavimentos-tipo, térreo, 2 subsolos, cobertura e ático. Cada pavimento tipo é composto por 2 apartamentos, além do hall social e de serviço. Com estrutura reticulada de concreto armado moldado in loco e lajes maciças e vedação vertical em paredes de blocos cerâmicos com posterior revestimento de argamassa (fachada) e pasta de gesso (paredes dos ambientes não-molháveis), a construção deste edifício, inicialmente pertencente à ENCOL, foi retomada por uma empresa construtora local para sua finalização, compreendendo todos os serviços de sistemas prediais e acabamentos em geral. Na Figura 5.5 ilustra-se uma vista geral do edifício. 


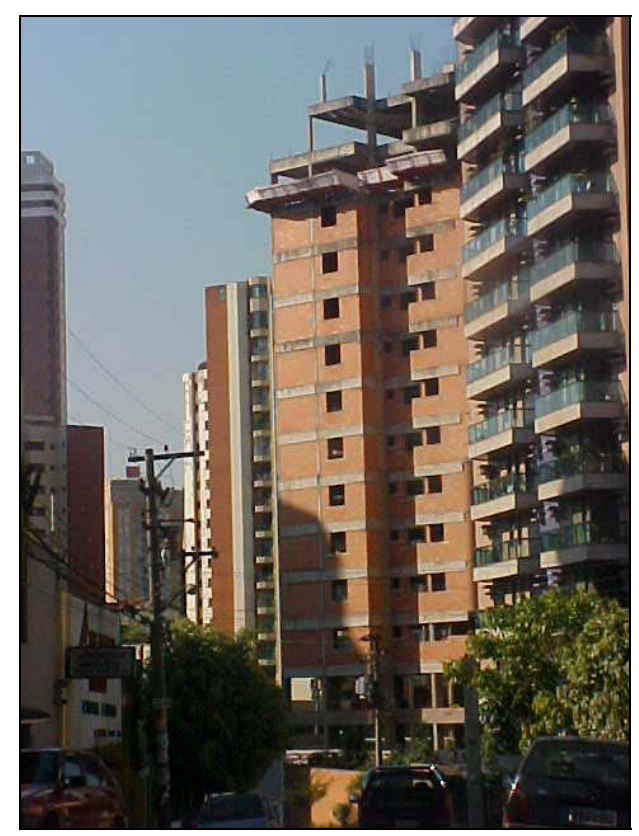

Figura 5.5 - Vista Geral da obra SP0701

\subsubsection{SP0702}

Trata-se de um edifício residencial cuja obra foi interrompida pela ENCOL, e os serviços foram retomados recentemente por uma empresa atuante na cidade de São Paulo. Possui 17 apartamentos-tipo, com 2 apartamentos por andar, duplex inferior e superior, pavimento térreo, 2 subsolos, cobertura e ático, concebido em estrutura reticulada de concreto armado moldado in loco, vedação vertical com paredes de blocos cerâmicos e revestimento externo em argamassa e interno em pasta de gesso.

\subsubsection{SP0801}

Trata-se de um edifício residencial destinado à classe média localizado na capital paulistana composto por 12 pavimentos-tipo com 4 apartamentos cada, duplex inferior e superior, térreo, 1 subsolo, cobertura e ático, em estrutura de concreto armado moldado in loco e vedação em paredes de blocos cerâmicos (Figura 5.6). 


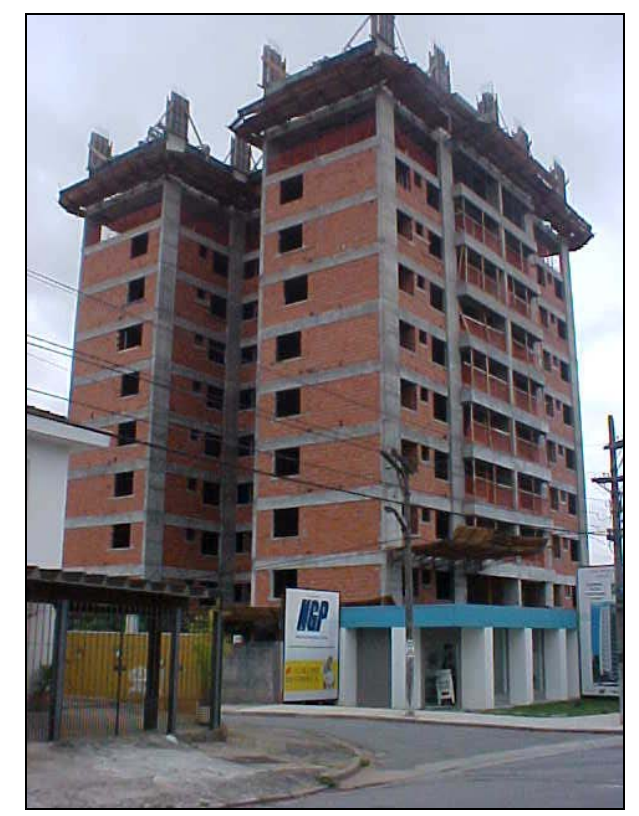

Figura 5.6 - Vista Geral da obra SP0801

\subsubsection{SP0901}

Trata-se de um edifício residencial voltado à classe média localizado na cidade de São Paulo, composto por 19 pavimentos-tipo, térreo, cobertura e ático, além de 2 subsolos, em estrutura reticulada de concreto armado e vedação vertical em blocos de concreto. O pavimento tipo possui 6 apartamentos sendo 4 com dois dormitórios, suíte, banheiro social, banheiro de empregada, sala de estar/jantar, terraço social, além da cozinha e área de serviço (SP0901a) e 2 apartamentos, de área menor, com dois dormitórios e banheiro social, além da cozinha, área de serviço, sala de estar/jantar e terraço social (SP0901b).

\subsubsection{SP1001}

Trata-se de um edifício residencial de alto padrão localizado na cidade de São Paulo, composto por 18 pavimentos-tipo, duplex inferior e superior, pavimento térreo, 
cobertura e ático, além de 2 subsolos, em estrutura reticulada de concreto armado e vedação vertical em blocos de concreto. Com apenas um apartamento por andar, como particularidade destaca-se o fato de possuir 4 suítes e uma grande área social. Nos ambientes molháveis e nos corredores nos quais passarão tubulações está previsto o uso de forro falso em gesso acartonado.

\subsubsection{SP1002}

Este edifício residencial, também de alto padrão, é composto por 17 pavimentos-tipo, duplex inferior e superior, cobertura e ático, mezanino e pavimento térreo e 3 subsolos. Concebido em estrutura de concreto armado moldado in loco e vedação vertical de paredes de blocos de concreto, possui dois apartamentos por andar.

\subsubsection{Resumo}

Nas tabelas 5.1 e 5.2 são resumidas, respectivamente, as características das edificações e do pavimento-tipo/apartamento-tipo. 
Tabela 5.1 Características gerais das edificações

\begin{tabular}{|c|c|c|c|c|c|c|c|c|c|c|c|c|c|}
\hline CARACTERÍSTICAS & SP0101 & SP0201 & SP0301 & SP0401 & SP0501 & SP0601 & SP0701 & SP0702 & SP0801 & SP0901a & SP0901b & SP1001 & SP1002 \\
\hline Número de torres & 2 & 1 & 1 & 2 & 1 & 1 & 1 & 1 & 1 & 1 & 1 & 1 & 1 \\
\hline Tipo de torre & Residencial & Residencial & Residencial & Residencial & Residencial & Residencial & Residencial & Residencial & Residencial & Residencial & Residencial & Residencial & Residencial \\
\hline $\begin{array}{l}\text { Número de } \\
\text { pavimentos-tipo }\end{array}$ & 16 & 13 & 20 & 17 & 22 & 22 & 13 & 17 & 12 & 19 & 19 & 18 & 17 \\
\hline Mezanino & 1 & 0 & 0 & 0 & 0 & 0 & 0 & 0 & 0 & 0 & 0 & 0 & 1 \\
\hline Número de subsolos & 2 & 1 & 3 & 1 & 2 & 2 & 2 & 2 & 1 & 2 & 2 & 2 & 3 \\
\hline $\begin{array}{l}\text { Apartamentos com } \\
\text { duplex inferior e } \\
\text { superior (Sim; Não) }\end{array}$ & Não & Sim & Sim & Sim & Não & Sim & Sim & Sim & Sim & Não & Não & Sim & Sim \\
\hline $\begin{array}{l}\text { Número de } \\
\text { pavimentos }^{30}\end{array}$ & 22 & 19 & 28 & 23 & 27 & 29 & 20 & 24 & 18 & 24 & 24 & 25 & 26 \\
\hline Estrutura & $\begin{array}{l}\text { Reticulada } \\
\text { de } \\
\text { concreto } \\
\text { armado }\end{array}$ & $\begin{array}{l}\text { Reticulada } \\
\text { de } \\
\text { concreto } \\
\text { armado }\end{array}$ & $\begin{array}{l}\text { Reticulada } \\
\text { de } \\
\text { concreto } \\
\text { armado }\end{array}$ & $\begin{array}{l}\text { Reticulada } \\
\text { de } \\
\text { concreto } \\
\text { armado }\end{array}$ & $\begin{array}{l}\text { Reticulada } \\
\text { de } \\
\text { concreto } \\
\text { armado }\end{array}$ & $\begin{array}{l}\text { Reticulada } \\
\text { de } \\
\text { concreto } \\
\text { armado }\end{array}$ & $\begin{array}{l}\text { Reticulada } \\
\text { de } \\
\text { concreto } \\
\text { armado }\end{array}$ & $\begin{array}{l}\text { Reticulada } \\
\text { de } \\
\text { concreto } \\
\text { armado }\end{array}$ & $\begin{array}{c}\text { Reticulada } \\
\text { de } \\
\text { concreto } \\
\text { armado }\end{array}$ & $\begin{array}{l}\text { Reticulada } \\
\text { de } \\
\text { concreto } \\
\text { armado }\end{array}$ & $\begin{array}{l}\text { Reticulada } \\
\text { de } \\
\text { concreto } \\
\text { armado }\end{array}$ & $\begin{array}{l}\text { Reticulada } \\
\text { de } \\
\text { concreto } \\
\text { armado }\end{array}$ & $\begin{array}{c}\text { Reticulada } \\
\text { de } \\
\text { concreto } \\
\text { armado }\end{array}$ \\
\hline Tipologia da laje & Maciça & Maciça & Maciça & Nervurada & Maciça & Maciça & Maciça & Maciça & Maciça & Maciça & Maciça & Maciça & Maciça \\
\hline
\end{tabular}

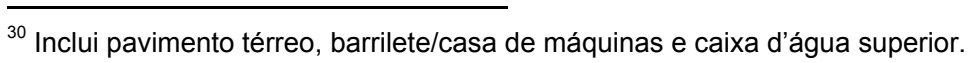

$\vec{D}$ 
Tabela 5.2 - Características gerais do pavimento-tipo/apartamento-tipo

\begin{tabular}{|c|c|c|c|c|c|c|c|c|c|c|c|c|c|}
\hline CARACTERÍSTICAS & SP0101 & SP0201 & SP0301 & SP0401 & SP0501 & SP0601 & SP0701 & SP0702 & SP0801 & SP0901a & SP0901b & SP1001 & SP1002 \\
\hline $\begin{array}{l}\text { Componente de } \\
\text { vedação }\end{array}$ & $\begin{array}{l}\text { Bloco } \\
\text { cerâmico }\end{array}$ & $\begin{array}{l}\text { Bloco } \\
\text { cerâmico }\end{array}$ & $\begin{array}{l}\text { Bloco de } \\
\text { concreto }\end{array}$ & $\begin{array}{l}\text { Bloco } \\
\text { cerâmico }\end{array}$ & $\begin{array}{l}\text { Bloco de } \\
\text { concreto }\end{array}$ & $\begin{array}{l}\text { Bloco } \\
\text { cerâmico }\end{array}$ & $\begin{array}{l}\text { Bloco } \\
\text { cerâmico }\end{array}$ & $\begin{array}{l}\text { Bloco } \\
\text { cerâmico }\end{array}$ & $\begin{array}{l}\text { Bloco } \\
\text { cerâmico }\end{array}$ & $\begin{array}{l}\text { Bloco de } \\
\text { concreto }\end{array}$ & $\begin{array}{l}\text { Bloco de } \\
\text { concreto }\end{array}$ & $\begin{array}{l}\text { Bloco de } \\
\text { concreto }\end{array}$ & $\begin{array}{l}\text { Bloco de } \\
\text { concreto }\end{array}$ \\
\hline $\begin{array}{l}\text { Número de } \\
\text { apartamentos por } \\
\text { pavimento-tipo }\end{array}$ & 2 & 2 & 1 & 4 & 4 & 1 & 2 & 2 & 4 & 6 & 6 & 1 & 2 \\
\hline \multicolumn{14}{|c|}{ Número de ambientes (apartamento-tipo) } \\
\hline Copa/Cozinha & 1 & 1 & 1 & 1 & 1 & 1 & 1 & 1 & 1 & 1 & 1 & 1 & 1 \\
\hline Área de serviço & 1 & 1 & 1 & 1 & 1 & 1 & 1 & 1 & 1 & 1 & 1 & 1 & 1 \\
\hline Salas estar/jantar & 2 & 1 & 1 & 1 & 1 & 2 & 1 & 1 & 1 & 1 & 1 & 2 & 1 \\
\hline Sala de almoço & 0 & 0 & 0 & 0 & 0 & 1 & 0 & 0 & 0 & 0 & 0 & 1 & 0 \\
\hline Sala TV & 1 & 0 & 0 & 0 & 0 & 0 & 0 & 0 & 0 & 0 & 0 & 0 & 0 \\
\hline Dormitório & 1 & 0 & 2 & 2 & 2 & 2 & 2 & 2 & 2 & 2 & 2 & 0 & 2 \\
\hline Suíte & 2 & 3 & 2 & 1 & 1 & 2 & 1 & 2 & 1 & 1 & 0 & 4 & 2 \\
\hline Sala íntima & 0 & 0 & 0 & 0 & 0 & 0 & 0 & 0 & 1 & 0 & 0 & 0 & 0 \\
\hline Banheiro social & 1 & 0 & 1 & 1 & 1 & 1 & 1 & 1 & 1 & 1 & 1 & 0 & 1 \\
\hline Lavabo & 1 & 1 & 1 & 0 & 0 & 1 & 1 & 1 & 1 & 0 & 0 & 1 & 1 \\
\hline
\end{tabular}


Tabela 5.2 - Características gerais do pavimento-tipo/apartamento-tipo (continuação)

\begin{tabular}{|c|c|c|c|c|c|c|c|c|c|c|c|c|c|}
\hline CARACTERÍSTICAS & SP0101 & SP0201 & SP0301 & SP0401 & SP0501 & SP0601 & SP0701 & SP0702 & SP0801 & SP0901a & SP0901b & SP1001 & SP1002 \\
\hline Hall social & 1 & 1 & 1 & 0 & 1 & 0 & 1 & 1 & 1 & 1 & 1 & 0 & 0 \\
\hline Hall privativo & 1 & 0 & 1 & 0 & 0 & 1 & 0 & 0 & 0 & 0 & 0 & 1 & 1 \\
\hline Hall serviço & 0 & 0 & 1 & 0 & 1 & 1 & 1 & 1 & 1 & 0 & 0 & 1 & 1 \\
\hline Elevador privativo & 1 & 1 & 2 & 0 & 0 & 1 & 0 & 0 & 0 & 0 & 0 & 1 & 1 \\
\hline Vestíbulo & 1 & 0 & 0 & 0 & 0 & 0 & 0 & 0 & 0 & 0 & 0 & 0 & 0 \\
\hline Terraço & 2 & 1 & 2 & 1 & 1 & 2 & 2 & 1 & 1 & 1 & 1 & 3 & 4 \\
\hline Closet & 1 & 0 & 1 & 0 & 1 & 1 & 0 & 0 & 0 & 0 & 0 & 0 & 0 \\
\hline Despensa & 0 & 0 & 0 & 0 & 1 & 0 & 0 & 1 & 0 & 1 & 0 & 0 & 0 \\
\hline $\begin{array}{l}\text { Dependências de } \\
\text { empregada }\end{array}$ & 1 & 1 & 1 & 0 & 0 & 1 & 1 & 0 & 0 & 0 & 0 & 1 & 1 \\
\hline $\begin{array}{l}\text { Banheiros de } \\
\text { empregada }\end{array}$ & 1 & 1 & 1 & 0 & 1 & 1 & 1 & 1 & 1 & 1 & 0 & 1 & 1 \\
\hline $\begin{array}{l}\text { Número de ambientes } \\
\text { molháveis }\end{array}$ & 9 & 8 & 9 & 5 & 6 & 9 & 8 & 8 & 7 & 6 & 4 & 11 & 11 \\
\hline \multicolumn{14}{|c|}{ Área $\left(\mathrm{m}^{2}\right)$} \\
\hline Pavimento-tipo & 374,09 & 304,19 & 231,25 & 361,86 & 391,28 & 248,27 & 225,79 & 285,47 & 418,63 & 461,93 & 461,93 & 236,28 & 355,62 \\
\hline Apartamento-tipo & 173,83 & 134,98 & 200,56 & 73,98 & 82,20 & 226,08 & 92,66 & 126,05 & 92,03 & 78,27 & 45,61 & 213,04 & 165,72 \\
\hline Área comum & 26,43 & 34,23 & 30,69 & 65,94 & 62,48 & 22,19 & 40,47 & 33,37 & 50,51 & 66,82 & 66,82 & 23,24 & 24,18 \\
\hline
\end{tabular}


Tabela 5.2 - Características gerais do pavimento-tipo/apartamento-tipo (continuação)

\begin{tabular}{|l|c|c|c|c|c|c|c|c|c|c|c|c|c|c|}
\hline CARACTERÍSTICAS & SP0101 & SP0201 & SP0301 & SP0401 & SP0501 & SP0601 & SP0701 & SP0702 & SP0801 & SP0901a & SP0901b & SP1001 & SP1002 \\
\hline \multicolumn{7}{|c|}{} \\
\hline Pavimento-tipo & 102,76 & 93,45 & 72,88 & 105,29 & 95,76 & 76,63 & 75,71 & 80,98 & 126,88 & 108,51 & 108,51 & 69,63 & 104,14 \\
\hline Apartamento-tipo & 69,20 & 51,41 & 48,90 & 32,25 & 40,73 & 70,05 & 55,30 & 59,09 & 44,02 & 39,33 & 29,54 & 63,68 & 63,64 \\
\hline Área comum & 25,45 & 30,02 & 23,98 & 36,65 & 51,60 & 19,14 & 39,03 & 34,03 & 45,16 & 46,07 & 46,07 & 20,27 & 22,22 \\
\hline Altura (piso a piso) (m) & 2,88 & 2,80 & 2,88 & 2,97 & 2,75 & 2,88 & 2,80 & 2,80 & 2,78 & 2,98 & 2,98 & 3,00 & 2,96 \\
\hline
\end{tabular}




\subsection{Características dos sistemas prediais}

Na seqüência são apresentadas as principais características dos sistemas prediais das edificações analisadas neste trabalho. Na Tabela 5.3 são resumidos os tipos de sistemas prediais previstos em cada edificação analisada, assim como os materiais dos componentes empregados em cada um.

Tabela 5.3 - Tipos de sistemas prediais existentes nas obras analisadas e os materiais empregados

\begin{tabular}{|c|c|c|c|c|c|c|}
\hline \multirow[t]{2}{*}{ Obras } & \multicolumn{6}{|c|}{ Sistemas prediais } \\
\hline & Água Fria & $\begin{array}{c}\text { Água } \\
\text { Quente }\end{array}$ & $\begin{array}{l}\text { Águas } \\
\text { Pluviais }\end{array}$ & Esgoto & Gás & Incêndio \\
\hline SP0101 & Cobre & Cobre & PVC & PVC & Cobre & Cobre \\
\hline SP0201 & PVC & Cobre & PVC & PVC & Cobre & Cobre \\
\hline SP0301 & Cobre & Cobre & PVC & PVC & Cobre & Cobre \\
\hline SP0401 & PVC & - & PVC & PVC & Cobre & Cobre \\
\hline SP0501 & PVC & Cobre & PVC & PVC & Cobre & Cobre \\
\hline SP0601 & PVC & Cobre & PVC & PVC & Cobre & Cobre \\
\hline SP0701 & PVC & Cobre & PVC & PVC & Cobre & Cobre \\
\hline SP0702 & PVC & Cobre & PVC & PVC & Cobre & Cobre \\
\hline SP0801 & PVC & Cobre & PVC & PVC & Cobre & Cobre \\
\hline SP0901a & PVC & Cobre & PVC & PVC & Cobre & Cobre \\
\hline SP0901b & PVC & Cobre & PVC & PVC & Cobre & Cobre \\
\hline SP1001 & PPR & PPR & PVC & PVC & Cobre & Cobre \\
\hline SP1002 & PPR & PPR & PVC & PVC & Cobre & Cobre \\
\hline
\end{tabular}

\subsubsection{Sistema predial de suprimento de água fria}

Todas as obras utilizaram o sistema de abastecimento indireto prevendo-se um reservatório inferior e outro superior. Observou-se também que este sistema foi concebido de tal forma que a alimentação de água fria nos apartamentos fosse feita a 
partir de uma única prumada localizada geralmente no hall de serviço ou na área de serviço de cada apartamento, possibilitando, assim, a medição individualizada do consumo de água.

Em função do limite da pressão estática de 40 m.c.a. (metros de coluna d'água) exigida pela NBR 5626 (ABNT, 1998), quase que na totalidade das obras analisadas houve a necessidade de se utilizar uma estação redutora de pressão, sistema de redução de pressão, criando-se duas zonas de alimentação: pavimentos alimentados diretamente do barrilete da caixa d'água superior e pavimentos alimentados a partir da válvula redutora de pressão, geralmente localizada no $1^{\circ}$ subsolo. A partir desta prumada, a água fria chega aos ambientes molháveis de cada apartamento através de um ramal de distribuição localizado, na maioria das obras, sob a laje de teto do apartamento e, em alguns casos, sob a laje de piso do apartamento.

Nos ambientes molháveis, os aparelhos sanitários são alimentados por ramais e subramais cujo traçado das tubulações era feito totalmente pelas paredes e, em alguns casos, pela parede e sob a laje de piso do apartamento. Na seqüência é feito um detalhamento deste sistema das obras estudadas.

\subsubsection{SP0101}

\section{Reservação e esquema vertical}

O subsistema de reservação é composto por dois reservatórios localizados no subsolo 2 de 56.000 litros cada, totalizando um volume de 112.000 litros, e dois reservatórios na cobertura, separados pela casa de máquinas, com capacidade total de 32.880 litros, sendo 12.400 litros destinados a reserva para prevenção e combate a incêndios. 
De cada reservatório superior partem duas prumadas específicas para cada apartamento do pavimento-tipo, sendo uma destinada à alimentação dos ambientes molháveis e outra para alimentação da torneira de lavagem existente no terraço social dos pavimentos superiores ao $8^{\circ}$ pavimento-tipo.

De cada reservatório partem também uma prumada para alimentação do sistema de aquecimento localizado no $1^{\circ}$ subsolo, e outra que liga este barrilete a um conjunto de válvulas redutoras de pressão. A partir deste conjunto, tanto a água quente quanto a água fria chegam aos pavimentos inferiores através de prumadas específicas (uma para alimentação de água fria dos ambientes molháveis e outra para alimentação da torneira de lavagem existente no terraço social).

\section{Ramal de distribuição para os ambientes, ramais e sub-ramais nos ambientes}

Da prumada de água fria presente no shaft da área de serviço nasce o ramal de distribuição localizado sob a laje de teto destinado à alimentação dos ambientes. Deste ramal de distribuição desce, para cada ambiente molhável, embutido na parede, um ramal vertical, do qual derivam ramais e sub-ramais que, dependendo do ambiente molhável, são posicionados sob a laje de piso do apartamento ou são totalmente embutidos nas paredes.

A concepção de ramais e sub-ramais "parede/sob a laje" foi adotada em todos os banheiros; na cozinha e área de serviço estes ramais e sub-ramais são todos embutidos na parede. Tanto os ramais e sub-ramais localizados sob a laje de piso quanto o ramal de distribuição localizado sob a laje de teto serão embutidos em um forro falso ou sanca. 


\subsubsection{SP0201}

\section{Reservação e esquema vertical}

O subsistema de reservação é composto por um reservatório superior de duas células com capacidade para 22.330 litros alimentado pelo reservatório inferior localizado no $1^{\circ}$ subsolo com capacidade para 22.970 litros através de uma tubulação de recalque localizada no shaft do hall de serviço.

Do barrilete do reservatório superior saem quatro conjuntos de prumadas de água fria distintas para cada apartamento dos pavimentos: uma para alimentar os ambientes molháveis do apartamento duplex, uma para alimentar os ambientes molháveis dos apartamentos dos pavimentos-tipo, uma para alimentar o sistema de aquecimento central privado e outra para alimentar a pia localizada no terraço social provido de churrasqueira. À exceção desta última prumada, as anteriores passam pelo shaft localizado entre a cozinha e a área de serviço de cada apartamento.

Para atender aos níveis de pressão exigidos pela NBR 5626 (ABNT, 1998), o subsistema de distribuição de água fria é dividido em duas partes: subsistema "alta" (que alimenta os pavimentos superiores ao quarto pavimento) e subsistema "baixa" (que alimenta os pavimentos inferiores ao quinto). Pelo shaft localizado no hall de serviço passa uma prumada específica que liga o barrilete do reservatório superior a duas válvulas redutoras de pressão localizadas no $1^{\circ}$ subsolo. De uma delas deriva a prumada para alimentação do sistema de aquecimento central privado dos pavimentos inferiores e da outra deriva a prumada que alimenta os ambientes molháveis e a pia do terraço social destes pavimentos.

$\mathrm{Na}$ extremidade da prumada que alimenta o sistema de aquecimento coletivo privado nos pavimentos inferiores há uma válvula de admissão de ar. O mesmo acontece na 
prumada que alimenta este sistema nos pavimentos superiores localizada na extremidade a montante.

Finalmente, o esquema vertical de suprimento de água fria contém também uma tubulação de aviso que passa pelo shaft do hall de serviço cuja extremidade inferior se localiza no piso do $1^{\circ}$ subsolo.

\section{Ramal de distribuição para os ambientes, ramais e sub-ramais nos ambientes}

Da prumada de água fria existente no shaft que divide a cozinha da área de serviço parte um ramal de distribuição interna ao pavimento-tipo, situado sob a laje de teto do apartamento, que alimenta os ambientes molháveis. A montante desta tubulação há a previsão para a instalação de um medidor de consumo de água localizado próximo ao teto. A partir da área de serviço, este ramal alimenta o banheiro de empregada, passando pela cozinha, chegando até o lavabo. A partir deste ponto há uma ramificação deste ramal: uma para alimentar o banheiro de suíte 1 e outra para alimentar os banheiros das suítes 2 e 3 . Os ramais que alimentam os banheiros das suítes 2 e 3 têm seu traçado localizado sobre a alvenaria de vedação. No restante, este ramal é fixado por meio de fita Walsywa chumbada na laje de teto do apartamento. Quando não se localiza sobre a alvenaria, o seu embutimento é feito através de sanca ou forro falso de gesso.

A alimentação dos ambientes é feita por ramais verticais embutidos na parede, geralmente localizados na parede do chuveiro. Os ramais e sub-ramais horizontais e verticais que alimentam os aparelhos sanitários têm seu traçado feito totalmente pelas paredes exigindo, portanto, que seja feito o prévio corte e rasgo destas paredes. 


\subsubsection{SP0301}

\section{Reservação e esquema vertical}

O subsistema de reservação é composto por 2 reservatórios, sendo o inferior localizado no $3^{\circ}$ subsolo com capacidade para 49.000 litros de água e o superior localizado no ático com capacidade para 57.300 litros, destinando-se deste último 12.000 litros para a reserva de combate a incêndios.

Do barrilete do reservatório superior partem uma prumada específica para alimentar os aparelhos sanitários do duplex inferior e superior e outros três conjuntos de prumadas para alimentação dos pavimentos-tipo. O primeiro conjunto consiste de duas prumadas para alimentar os aparelhos sanitários dos ambientes dos pavimentos. A primeira prumada alimenta os pavimentos superiores $\left(20^{\circ}\right.$ pavimento-tipo ao $10^{\circ}$ pavimento-tipo) e segue diretamente para uma válvula redutora de pressão localizada no $1^{\circ}$ subsolo. Após passar por esta válvula, vem alimentando os pavimentos inferiores ao $10^{\circ}$ pavimento e, a partir deste, sobe diretamente para a cobertura do edifício configurando-se, assim, em uma tubulação de respiro.

O segundo conjunto de prumadas segue o mesmo princípio do primeiro, diferindo apenas no que diz respeito a sua finalidade. Neste caso, este conjunto serve para alimentar o aquecedor localizado na área de serviço do apartamento-tipo.

Finalmente, o terceiro conjunto é composto apenas por uma prumada para alimentação de uma torneira destinada de lavagem existente no terraço da sala de estar. Do barrilete do reservatório superior parte uma prumada que alimenta o terraço da sala de estar dos pavimentos-tipo superiores (do $20^{\circ}$ ao $10^{\circ}$ pavimento-tipo) enquanto que os pavimentos-tipo inferiores ao $10^{\circ}$ são alimentados por uma prumada derivada da válvula redutora de pressão localizada no $1^{\circ}$ subsolo. 
Todas estas prumadas, à exceção da que alimenta a torneira do terraço da sala de estar, passam pelo shaft localizado entre a área de serviço e banheiro de empregada do apartamento-tipo enquanto que da tubulação de recalque, juntamente com a prumada de incêndio, localizam-se no shaft do hall de serviço.

\section{Ramal de distribuição para os ambientes, ramais e sub-ramais nos ambientes}

Da prumada de alimentação de água fria nos pavimentos parte o ramal de distribuição cujo traçado é feito sob a laje de teto de cada apartamento (embutimento por meio de forro falso ou sanca de gesso) tendo, no seu início, a previsão de instalação do medidor de consumo de água. A partir deste medidor, este ramal de distribuição ramifica-se em duas partes. A primeira para suprir a área de serviço, cozinha e lavabo, enquanto que a segunda se destina à alimentação do banheiro social e banheiro das suítes.

Deste ramal de distribuição, deriva, para cada ambiente, um ramal vertical junto ao shaft provido de registro. Este ramal, além de alimentar o chuveiro (exceto no lavabo), alimenta também os outros pontos de consumo de água fria do ambiente na medida em que, da extremidade inferior do mesmo, localizado abaixo da laje de piso do pavimento, partem os ramais horizontais para alimentação dos sub-ramais que, por sua vez, alimentam os outros aparelhos sanitários, tais como duchas higiênicas, bacia sanitária e lavatórios.

Esta concepção (ramais pela parede e sob o teto de piso do apartamento) se aplica aos banheiros e lavabos. No caso da área de serviço e cozinha, os ramais e subramais são totalmente embutidos nas paredes, ou seja, não passam sob a laje de piso do pavimento até chegar aos pontos de consumo (pias, tanque(s) e máquina de lavar roupas). 


\subsubsection{SP0401}

\section{Reservação e esquema vertical}

Esta obra tem como particularidade a inexistência de um sistema de aquecimento central. O sistema de abastecimento de água fria é dividido em duas partes em função da necessidade de redução da pressão estática nas tubulações: uma para alimentação dos pavimentos superiores (do duplex superior ao $9^{\circ}$ pavimento-tipo) e outra para alimentação dos pavimentos inferiores ao $9^{\circ}$ pavimento-tipo.

Do barrilete do reservatório superior com capacidade total de 48.000 litros, sendo 18.000 destinados à prevenção e combate a incêndios, parte uma prumada de água fria para alimentação dos pavimentos superiores e outra para alimentação da válvula redutora de pressão localizada no subsolo. A partir desta válvula redutora de pressão, parte uma prumada para alimentação dos pavimentos inferiores.

Estas prumadas, assim como a de aviso e de recalque se localizam no shaft presente no hall comum aos apartamentos.

\section{Ramal de distribuição para os ambientes, ramais e sub-ramais nos ambientes}

A partir de uma única prumada de alimentação (seja proveniente do reservatório superior ou da válvula redutora de pressão) partem os ramais de distribuição independentes para cada apartamento-tipo.

A montante destes ramais, há a previsão de instalação de medidor de consumo de água. A partir deste, cada ramal de distribuição segue pelo teto (sob a laje de teto do apartamento) até o respectivo apartamento-tipo e alimenta os ambientes molháveis, passando inicialmente pela cozinha e área de serviço e chegando, ao seu final, aos banheiros social e da suíte. 
A alimentação da cozinha e da área de serviço é feita por um único ramal vertical que deriva desta distribuição, prolonga-se por debaixo da laje de piso do apartamento e chega aos pontos de consumo rente às paredes. Os sub-ramais verticais rentes às paredes serão embutidos em carenagens. A mesma concepção é aplicada aos banheiros social e da suíte. Um único ramal vertical deriva do ramal de distribuição para alimentação dos dois ambientes.

\subsubsection{SP0501}

\section{Reservação e esquema vertical}

Esta obra possui 4 reservatórios pré-fabricados cilíndricos (interligados em grupos de dois) localizados no $2^{\circ}$ subsolo com capacidade de 15.000 litros cada. A água é recalcada destes reservatórios até o reservatório superior de concreto armado dividido em duas células com capacidade total de 50.000 litros, sendo 18.000 litros destinados à reserva de incêndio através de uma tubulação de recalque localizada no shaft do hall de serviço do edifício.

Do barrilete do reservatório superior partem quatro prumadas (uma para cada apartamento) que alimentam os ambientes molháveis dos pavimentos superiores (do $20^{\circ}$ ao $11^{\circ}$ pavimento-tipo) através do shaft localizado junto ao banheiro de empregada e uma única prumada que desce até a válvula redutora de pressão localizada no pavimento térreo, da qual derivam prumadas independentes para cada apartamento-tipo dos pavimentos inferiores ao $11^{\circ}$.

A alimentação dos apartamentos-tipo do $21^{\circ}$ e do $22^{\circ}$ pavimentos é feita por prumadas independentes dos demais pavimentos. Estas prumadas partem do barrilete e passam por um sistema de pressurização antes de seguirem para os mesmos. 
Além das prumadas de alimentação, destaca-se também a tubulação de aviso que sai do reservatório superior e desce pelo shaft junto ao banheiro de empregada de um dos apartamentos do pavimento-tipo prolongando-se até o pavimento térreo.

\section{Ramal de distribuição para os ambientes, ramais e sub-ramais nos ambientes}

Internamente aos apartamentos-tipo, a distribuição da água fria até os ambientes molháveis é feita por um ramal localizado sob a laje de teto de cada apartamento passando pelo banheiro de empregada, área de serviço, banheiro social, chegando até ao banheiro da suíte.

Nos ambientes, a alimentação de água aos aparelhos sanitários é feita por ramais e sub-ramais cujo traçado se concentra totalmente nas paredes. A alimentação de água da cozinha é feita através da extensão do ramal da área de serviço.

\subsubsection{SP0601}

\section{Reservação e esquema vertical}

A água fria deste edifício é recalcada do reservatório inferior de concreto armado com duas células com capacidade total de 37.200 litros até o reservatório superior, também de concreto armado, com capacidade de 39.800 litros, sendo 15.000 litros destinados à prevenção e combate a incêndio através de uma tubulação de recalque localizada no shaft do hall de serviço.

Do barrilete do reservatório superior partem três conjuntos de prumadas. O primeiro deles, composto por duas prumadas, uma para alimentar os aparelhos sanitários dos apartamentos-tipo e outra para alimentar o aquecedor localizado na área de serviço 
destes apartamentos, que se estendem até o $12^{\circ}$ pavimento-tipo. $O$ segundo conjunto de prumadas tem a mesma finalidade, porém, se destina à alimentação dos pavimentos inferiores ao $12^{\circ}$ pavimento-tipo. Assim, as prumadas partem do barrilete e chegam diretamente às válvulas redutoras de pressão localizadas no $1^{\circ}$ subsolo para, em seguida, alimentar, respectivamente, os aparelhos sanitários e os aquecedores destes pavimentos. Destas, a prumada que alimenta os aparelhos sanitários tem seu comprimento interrompido no $11^{\circ}$ pavimento-tipo, enquanto a que alimenta os aquecedores prolonga-se diretamente até a cobertura do edifício de forma a conduzir os possíveis vapores formados no sistema de aquecimento.

Finalmente, $\circ 3^{\circ}$ conjunto, que é composto por uma única prumada que passa pelo terraço social e tem o objetivo de provê-lo de água fria, uma vez que está prevista a construção de uma churrasqueira no mesmo. Os ambientes molháveis do duplex superior são alimentados por uma prumada distinta dos demais pavimentos em função da necessidade de a água passar por um sistema de pressurização antes de chegar aos pontos de consumo deste pavimento.

\section{Ramal de distribuição para os ambientes, ramais e sub-ramais nos ambientes}

No apartamento-tipo, o ramal de distribuição de água fria, posicionado sob a laje de teto, alimenta os ambientes molháveis, passando pela área de serviço e ramificandose para os demais. Traçado semelhante possui também o ramal exclusivo de alimentação do aquecedor de acumulação localizado na área de serviço do apartamento-tipo. Nos ambientes molháveis, a água fria chega até os pontos de consumo através de ramais e sub-ramais localizados exclusivamente nas paredes. 


\subsubsection{SP0701}

\section{Reservação e esquema vertical}

A água fria é recalcada do reservatório inferior de concreto armado com capacidade para 29.460 litros através de uma tubulação de recalque situada no shaft do hall de serviço até o reservatório superior, também de concreto armado, ambos com duas células.

O subsistema de distribuição vertical de água fria deste edifício é dividido em três partes: uma destinada para alimentar o pavimento duplex e $13^{\circ}$ e $12^{\circ}$ pavimentos-tipo, outra para alimentação dos pavimentos abaixo deste último, porém até $04^{\circ}$ pavimento-tipo e uma terceira parte para o abastecimento dos pavimentos-tipo inferiores a este, provida de válvula redutora de pressão localizada no $1^{\circ}$ subsolo.

Assim, em se tratando da primeira situação, a água fria antes de chegar aos pontos de consumo, passa por um sistema de pressurização localizado na cobertura. A partir deste sistema derivam-se duas prumadas (uma para cada apartamento dos pavimentos).

A alimentação dos pavimentos superiores, porém abaixo do $12^{\circ}$ pavimento-tipo, é feita por duas prumadas independentes (uma para cada apartamento) que passam pelo shaft localizado na área de serviço de cada um. A prumada de um destes apartamentos prolonga-se até o subsolo e alimenta uma válvula redutora de pressão localizada neste pavimento. A partir dela, é feita a distribuição da água fria através de duas prumadas independentes para alimentação dos pavimentos inferiores ao $4^{\circ}$ pavimento. Na extremidade destas prumadas há a previsão da instalação de ventosas. 


\section{Ramal de distribuição para os ambientes, ramais e sub-ramais nos ambientes}

A alimentação de água fria em cada apartamento é feita por um ramal de distribuição situado abaixo da laje de teto. Do shaft da área de serviço, este ramal ramifica-se para alimentar o banheiro de empregada, cozinha e demais ambientes molháveis. Nestes ambientes, a água chega aos pontos de consumo através de ramais e sub-ramais embutidos nas paredes (cozinha, área de serviço, banheiro de empregada) ou também situados sob a laje de piso do apartamento (banheiro social e banheiro da suíte).

\subsubsection{SP0702}

\section{Reservação e esquema vertical}

O esquema vertical de distribuição de água fria entre os pavimentos desta obra se assemelha em parte ao da obra anterior. Em função da questão do atendimento dos valores mínimo e máximo de pressão estática, este subsistema possui uma prumada específica para atender aos pavimentos superiores (duplex, $16^{\circ}$ e $17^{\circ}$ pavimentos-tipo) associada a um sistema de pressurização.

Além desta prumada, outra deriva do barrilete do pavimento superior e alimenta os pavimentos inferiores ao $16^{\circ}$, até o $8^{a}$ pavimento-tipo. Os pavimentos inferiores a este são atendidos por uma prumada associada a um sistema de redução de pressão (válvula redutora de pressão) instalada no $1^{\circ}$ subsolo do edifício. A água, para chegar a estes apartamentos, sai do barrilete do reservatório superior, desce por uma tubulação específica até a válvula redutora de pressão e é encaminhada até estes por esta prumada. Tanto estas prumadas quanto a tubulação de recalque e de limpeza/aviso passam pelo shaft localizado no hall de serviço do edifício. 


\section{Ramal de distribuição para os ambientes, ramais e sub-ramais nos ambientes}

O subsistema de distribuição nos pavimentos, ao contrário das outras obras, é um pouco diferenciado. Esta diferença consiste no fato de o ramal de distribuição passar não somente sob a laje de teto do pavimento, mas sim em partes, também sob a laje de piso do pavimento. O ramal de distribuição vem sob a laje de teto de cada apartamento a partir da prumada localizada no shaft do hall de serviço e alimenta o banheiro de empregada e área de serviço. A partir destes ambientes, toda a distribuição de água fria para os demais ambientes é feito sob a laje de piso de cada apartamento.

Como decorrência, a alimentação dos banheiros é feita por um ramal rente à parede posicionado abaixo dos lavatórios, local onde é instalado o registro de gaveta para, em seguida, ter seu traçado voltado novamente para abaixo da laje de piso para alimentar outros aparelhos sanitários destes ambientes. Em particular, pelo fato de se ter dois banheiros adjacentes (o banheiro social localiza-se ao lado do banheiro de uma das suítes) a alimentação de água fria do banheiro social é feita diretamente por um ramal vindo do banheiro da suíte, não possuindo, portanto, um registro de controle específico para este ambiente.

\subsubsection{SP0801}

\section{Reservação e esquema vertical}

Dos reservatórios superiores, com capacidade para 34.980 litros saem as tubulações que alimentam os pavimentos. Ao contrário do observado nos sistemas das obras anteriormente apresentadas, esta não é provida de sistema de redução de pressão. A água fria chega a cada apartamento por prumadas específicas. Estas prumadas alimentam os apartamentos inferiores ao $12^{\circ}$ pavimento. Os pavimentos superiores a 
este são alimentados por prumadas associadas a um sistema de pressurização de forma a garantir a pressão dinâmica mínima nos pontos de consumo dos apartamentos destes pavimentos. A prumada que alimenta cada apartamento desce pelo shaft localizado na área de serviço, enquanto que a tubulação de recalque juntamente com a de incêndio se localizam no shaft do hall de serviço. A tubulação de limpeza e extravasão (ladrão) termina na própria laje de cobertura.

\section{Ramal de distribuição para os ambientes, ramais e sub-ramais nos ambientes}

A distribuição de água fria nos apartamentos é feita por um ramal situado abaixo da laje de teto de cada apartamento. Dela, para cada ambiente derivam ramais verticais providos de registro de gaveta para alimentação dos pontos de consumo. Estes ramais, assim como os sub-ramais têm seu traçado totalmente feito pelas paredes.

\subsubsection{SP0901a e SP0901b}

\section{Reservação e esquema vertical}

A edificação possui em sua cobertura, oito caixas d'água pré-fabricadas cilíndricas divididas em dois conjuntos de quatro caixas. Cada conjunto alimenta três apartamentos por andar com prumadas individuais para cada apartamento. Estas prumadas servem os pavimentos superiores e descem para um conjunto de válvulas redutoras de pressão localizadas no $1^{\circ}$ subsolo. Deste conjunto de válvulas, partem as prumadas para alimentação dos pavimentos inferiores. 


\section{Ramal de distribuição para os ambientes, ramais e sub-ramais nos ambientes}

De cada prumada que passa pelo shaft do banheiro social nos apartamentos com suíte (SP0901a) e pelo shaft da área de serviço nos apartamentos sem suíte (SP0901b) deriva, sob a laje de teto do apartamento, um ramal de distribuição com previsão para futura instalação de medidor de consumo de água. Esta tubulação desce pelo mesmo shaft e alimenta os ambientes sob a laje de piso do apartamento. Para cada ambiente molhável, do ramal de distribuição localizado sob a laje de piso, parte um ramal vertical provido de registro de gaveta a 2,10 m em relação ao piso acabado. Um pouco acima da posição deste registro, o ramal desce novamente para abaixo da laje de piso do pavimento para a alimentação dos pontos de consumo do ambiente.

\subsubsection{SP1001}

\section{Reservação e esquema vertical}

Por questões de limitação da pressão estática máxima nas tubulações e de forma a garantir a pressão dinâmica mínima nos pontos de consumo, o esquema vertical de distribuição de água fria deste edifício faz uso de válvula redutora de pressão localizada no $1^{\circ}$ subsolo, e de um sistema de pressurização para a prumada de alimentação dos pavimentos superiores.

Assim, do barrilete do reservatório superior com capacidade de armazenamento de 68.000 litros de água, sendo 18.000 litros para o combate a incêndios, parte uma prumada para alimentação dos pavimentos superiores (duplex superior e inferior) provida deste sistema de pressurização. Deste mesmo barrilete, parte outra prumada para o abastecimento dos pavimentos inferiores ao duplex inferior, até o $9^{a}$ pavimento, 
e uma específica para alimentar a pia existente no terraço social. Os pavimentos inferiores a este são alimentados por uma prumada que tem a montante um conjunto de válvulas redutoras de pressão. Destas válvulas, partem uma prumada que alimenta os ambientes internos do apartamento e outra prumada específica de água fria localizada terraço social. A água fria chega ao conjunto de válvulas através de uma tubulação específica que sai do barrilete do reservatório superior. As tubulações de recalque de água fria e distribuição vertical para os pavimentos se localizam no shaft do hall de serviço.

\section{Ramal de distribuição para os ambientes, ramais e sub-ramais nos ambientes}

Da prumada deriva o ramal de distribuição que tem por finalidade levar a água fria aos ambientes molháveis. A montante deste ramal há a previsão de instalação de medidor de consumo de água. Este ramal ramifica-se pelo apartamento sob a laje de teto do mesmo. Ao passar ou chegar a um ambiente molhável (banheiro, cozinha etc.) deriva um ramal vertical provido de registro de gaveta. Deste, partem os ramais e sub-ramais que alimentam os pontos de consumo de cada ambiente exclusivamente pela parede.

\subsubsection{SP1002}

\section{Reservação e esquema vertical}

Do reservatório inferior em concreto armado, com capacidade para 21.900 litros, a água é recalcada através de uma tubulação até o reservatório superior, com capacidade total de 55.000 litros, sendo 18.000 para combate a incêndios. Do barrilete deste reservatório derivam duas prumadas (uma para cada apartamento) para alimentação dos pavimentos superiores (do duplex superior ao $8^{\circ}$ pavimento tipo) e 
outra, cuja extremidade passa por um conjunto de válvulas redutoras de pressão localizado no mezanino do edifício. Deste conjunto derivam prumadas específicas para alimentação dos pavimentos inferiores ao $8^{\circ}$ pavimento-tipo. Além das prumadas destinadas à alimentação dos ambientes internos aos pavimentos, do barrilete do reservatório superior parte também uma prumada destinada ao abastecimento das pias localizadas nos terraços sociais dos apartamentos dos pavimentos superiores ao $7^{\circ}$ pavimento-tipo. Este pavimento e os inferiores a este são abastecidos pela prumada que sai da válvula redutora de pressão.

\section{Ramal de distribuição para os ambientes, ramais e sub-ramais nos ambientes}

Da prumada específica para alimentação de cada apartamento deriva um ramal de distribuição cujo traçado se situa abaixo da laje de teto do apartamento, tendo-se, no seu início, a previsão para instalação do medidor de consumo de água. Este ramal alimenta os ambientes molháveis do apartamento através de um ramal vertical provido de registro de gaveta, do qual derivam ramais e sub-ramais embutidos nas paredes que levam a água até os pontos de consumo. Apenas o lavabo possui um ramal que localizado sob a laje de teto. Nos demais, estes ramais e sub-ramais estão embutidos na sua totalidade nas paredes.

\subsubsection{Resumo das características do sistema predial de suprimento de água fria}

Na Tabela 5.4 apresenta-se um resumo das características deste sistema descritas anteriormente. 
Tabela 5.4 - Resumo das características do sistema predial de suprimento de água fria das obras analisadas

\begin{tabular}{|c|c|c|c|c|c|c|c|c|c|c|c|c|c|}
\hline CARACTERÍSTICAS & SP0101 & SP0201 & SP0301 & SP0401 & SP0501 & SP0601 & SP0701 & SP0702 & SP0801 & SP0901a & SP0901b & SP1001 & SP1002 \\
\hline $\begin{array}{l}\text { Volume do reservatório } \\
\text { inferior }\left(\mathrm{m}^{3}\right)\end{array}$ & 56,00 & 22,97 & 49,00 & - & 60,00 & 37,20 & 29,46 & - & 79,00 & - & - & - & 21,90 \\
\hline $\begin{array}{l}\text { Volume total do } \\
\text { reservatório superior } \\
\left(\mathrm{m}^{3}\right)\end{array}$ & 32,88 & 22,33 & 57,30 & 50,00 & 39,80 & - & 44,00 & 34,98 & 34,98 & - & - & 68,00 & 55,00 \\
\hline $\begin{array}{l}\text { Necessidade de válvula } \\
\text { redutora de pressão? }\end{array}$ & Sim & Sim & Sim & Sim & Sim & Sim & Sim & Sim & Não & Sim & Sim & Sim & Sim \\
\hline $\begin{array}{l}\text { Prumada específica } \\
\text { para alimentação da } \\
\text { válvula redutora de } \\
\text { pressão? }\end{array}$ & Sim & Sim & Não & Sim & Sim & Sim & Não & Sim & N.S.A. & Não & Não & Sim & Sim \\
\hline $\begin{array}{l}\text { Necessidade de } \\
\text { pressurização para } \\
\text { atender pavimentos } \\
\text { superiores? }\end{array}$ & Não & Não & Sim & Não & Sim & Sim & Sim & Sim & Sim & Não & Não & Sim & Sim \\
\hline $\begin{array}{l}\text { Prumada independente } \\
\text { no terraço? }\end{array}$ & Sim & Sim & Sim & N.S.A. & N.S.A. & Sim & N.S.A. & N.S.A. & N.S.A. & N.S.A. & N.S.A. & Sim & Sim \\
\hline $\begin{array}{l}\text { Prumada específica por } \\
\text { apartamento? }\end{array}$ & Sim & Sim & Sim & Não & Sim & Sim & Sim & Não & Sim & Sim & Sim & Sim & Sim \\
\hline $\begin{array}{l}\text { Prumada exclusiva } \\
\text { para alimentação do } \\
\text { aquecedor? }\end{array}$ & Sim & Sim & Sim & N.S.A. & Não & Sim & Não & Não & Não & Não & Não & Não & Não \\
\hline
\end{tabular}

Observação: N.S.A. = Não se aplica. 
Tabela 5.4 - Resumo das características do sistema predial de suprimento de água fria das obras analisadas (continuação)

\begin{tabular}{|c|c|c|c|c|c|c|c|c|c|c|c|c|c|}
\hline CARACTERÍSTICAS & SP0101 & SP0201 & SP0301 & SP0401 & SP0501 & SP0601 & SP0701 & SP0702 & SP0801 & SP0901a & SP0901b & SP1001 & SP1002 \\
\hline $\begin{array}{l}\text { Posicionamento do } \\
\text { ramal de distribuição }\end{array}$ & $\begin{array}{l}\text { Sob a laje } \\
\text { de teto }\end{array}$ & $\begin{array}{c}\text { Sob a laje } \\
\text { de teto }\end{array}$ & $\begin{array}{l}\text { Sob a laje } \\
\text { de teto }\end{array}$ & $\begin{array}{l}\text { Sob a laje } \\
\text { de teto }\end{array}$ & $\begin{array}{l}\text { Sob a laje } \\
\text { de teto }\end{array}$ & $\begin{array}{l}\text { Sob a laje } \\
\text { de teto }\end{array}$ & $\begin{array}{l}\text { Sob a laje } \\
\text { de teto }\end{array}$ & $\begin{array}{l}\text { Sob a laje } \\
\text { de teto e } \\
\text { de piso }\end{array}$ & $\begin{array}{c}\text { Sob a laje } \\
\text { de teto }\end{array}$ & $\begin{array}{l}\text { Sob a laje } \\
\text { de piso }\end{array}$ & $\begin{array}{l}\text { Sob a laje } \\
\text { de piso }\end{array}$ & $\begin{array}{l}\text { Sob a laje } \\
\text { de teto }\end{array}$ & $\begin{array}{l}\text { Sob a laje } \\
\text { de teto }\end{array}$ \\
\hline $\begin{array}{l}\text { Posicionamento dos } \\
\text { ramais e sub-ramais } \\
\text { nos ambientes } \\
\text { molháveis }\end{array}$ & $\begin{array}{c}\text { Embutidos } \\
\text { nas } \\
\text { paredes }\end{array}$ & $\begin{array}{c}\text { Embutidos } \\
\text { nas } \\
\text { paredes }\end{array}$ & $\begin{array}{c}\text { Embutidos } \\
\text { nas } \\
\text { paredes e } \\
\text { sob a laje } \\
\text { de piso }\end{array}$ & $\begin{array}{c}\text { Embutidos } \\
\text { nas } \\
\text { paredes e } \\
\text { sob a laje } \\
\text { de piso }\end{array}$ & $\begin{array}{c}\text { Embutidos } \\
\text { nas } \\
\text { paredes }\end{array}$ & $\begin{array}{c}\text { Embutidos } \\
\text { nas } \\
\text { paredes }\end{array}$ & $\begin{array}{l}\text { Embutidos } \\
\text { nas } \\
\text { paredes e } \\
\text { sob a laje } \\
\text { de piso }\end{array}$ & $\begin{array}{l}\text { Embutidos } \\
\text { nas } \\
\text { paredes e } \\
\text { sob a laje } \\
\text { de piso }\end{array}$ & $\begin{array}{c}\text { Embutidos } \\
\text { nas } \\
\text { paredes }\end{array}$ & $\begin{array}{c}\text { Embutidos } \\
\text { nas } \\
\text { paredes e } \\
\text { sob a laje } \\
\text { de piso }\end{array}$ & $\begin{array}{c}\text { Embutidos } \\
\text { nas } \\
\text { paredes e } \\
\text { sob a laje } \\
\text { de piso }\end{array}$ & $\begin{array}{c}\text { Embutidos } \\
\text { nas } \\
\text { paredes }\end{array}$ & $\begin{array}{c}\text { Embutidos } \\
\text { nas } \\
\text { paredes }\end{array}$ \\
\hline
\end{tabular}




\subsubsection{Sistema predial de suprimento de água quente}

Das obras analisadas, somente na SP0401 não se fez a previsão de um sistema de aquecimento central privado ou central coletivo. As demais foram concebidas prevendo-se um sistema de aquecimento, seja de passagem ou de acumulação ou, ainda, através da associação destes dois tipos de sistema tendo-se o gás como fonte de energia.

Como diferenças, podem ser apontadas, além do tipo de sistema de aquecimento, a existência ou não de tubulação de circulação (retorno) da água quente no apartamento e a alimentação do aquecedor por prumada exclusiva ou não.

O traçado do ramal de distribuição nos apartamentos e ramais e sub-ramais nos ambientes molháveis seguem o mesmo princípio adotado para os de água fria apresentados anteriormente, e as tubulações seguem em paralelo aos da água fria.

As principais características deste sistema são apresentadas na Tabela 5.5, a seguir. A omissão de informações nesta tabela se deve ao fato do autor não ter tido o acesso ao projeto completo dos sistemas prediais, e não pela falta de especificação no projeto. 
Tabela 5.5 - Resumo das características do sistema predial de suprimento de água quente das obras analisadas

\begin{tabular}{|c|c|c|c|c|c|c|c|c|c|c|c|c|c|}
\hline CARACTERÍSTICAS & SP0101 & SP0201 & SP0301 & SP0401 & SP0501 & SP0601 & SP0701 & SP0702 & SP0801 & SP0901a & SP0901b & SP1001 & SP1002 \\
\hline Tipo & $\begin{array}{l}\text { Central } \\
\text { coletivo }\end{array}$ & $\begin{array}{l}\text { Central } \\
\text { privado }\end{array}$ & $\begin{array}{l}\text { Central } \\
\text { privado }\end{array}$ & N.S.A. & $\begin{array}{l}\text { Central } \\
\text { privado }\end{array}$ & $\begin{array}{l}\text { Central } \\
\text { privado }\end{array}$ & $\begin{array}{l}\text { Central } \\
\text { privado }\end{array}$ & $\begin{array}{l}\text { Central } \\
\text { privado }\end{array}$ & $\begin{array}{l}\text { Central } \\
\text { privado }\end{array}$ & $\begin{array}{l}\text { Central } \\
\text { privado }\end{array}$ & $\begin{array}{l}\text { Central } \\
\text { privado }\end{array}$ & $\begin{array}{l}\text { Central } \\
\text { privado }\end{array}$ & $\begin{array}{l}\text { Central } \\
\text { privado }\end{array}$ \\
\hline $\begin{array}{l}\text { Geração de água } \\
\text { quente }\end{array}$ & $\begin{array}{l}\text { Aquecedor } \\
\text { de } \\
\text { passagem } \\
\text { conjugado } \\
\text { com } \\
\text { tanque de } \\
\text { acum. }\end{array}$ & $\begin{array}{l}\text { Aquecedor } \\
\text { de acum. }\end{array}$ & $\begin{array}{l}\text { Aquecedor } \\
\text { de } \\
\text { passagem } \\
\text { conjugado } \\
\text { com } \\
\text { tanque de } \\
\text { acum. }\end{array}$ & N.S.A. & $\begin{array}{l}\text { Aquecedor } \\
\text { de } \\
\text { passagem }\end{array}$ & $\begin{array}{l}\text { Aquecedor } \\
\text { de acum. }\end{array}$ & $\begin{array}{l}\text { Aquecedor } \\
\text { de } \\
\text { passagem }\end{array}$ & $\begin{array}{l}\text { Aquecedor } \\
\text { de } \\
\text { passagem }\end{array}$ & $\begin{array}{l}\text { Aquecedor } \\
\text { de } \\
\text { passagem }\end{array}$ & $\begin{array}{l}\text { Aquecedor } \\
\text { de } \\
\text { passagem }\end{array}$ & $\begin{array}{l}\text { Aquecedor } \\
\text { de } \\
\text { passagem }\end{array}$ & $\begin{array}{l}\text { Aquecedor } \\
\text { de } \\
\text { passagem } \\
\text { conjugado } \\
\text { com } \\
\text { tanque de } \\
\text { acum. }\end{array}$ & $\begin{array}{c}\text { Aquecedor } \\
\text { de } \\
\text { passagem } \\
\text { conjugado } \\
\text { com } \\
\text { tanque de } \\
\text { acum. }\end{array}$ \\
\hline Fonte de energia & Gás & Gás & Gás & N.S.A. & Gás & Gás & Gás & Gás & Gás & Gás & Gás & Gás & Gás \\
\hline $\begin{array}{l}\text { Capacidade de } \\
\text { acumulação (litros) }\end{array}$ & $\begin{array}{l}2000 \text { por } \\
\text { torre }\end{array}$ & $\begin{array}{l}150 \text { por } \\
\text { apto. }\end{array}$ & $\begin{array}{l}200 \text { por } \\
\text { apto. }\end{array}$ & N.S.A & - & $\begin{array}{l}300 \text { por } \\
\text { apto. }\end{array}$ & - & - & - & - & - & 200 & 200 \\
\hline $\begin{array}{l}\text { Capacidade de } \\
\text { aquecimento } \\
\text { (litros/min) }\end{array}$ & - & - & 20 & N.S.A & - & - & 20 & 30 & 20 & 30 & 30 & 30 & 30 \\
\hline Potência (kcal/hora) & - & 45.000 & - & N.S.A & 38.000 & - & 24.400 & 41.400 & - & - & - & - & - \\
\hline $\begin{array}{l}\text { Ramal de circulação } \\
\text { no apartamento? }\end{array}$ & Sim & Não & Não & N.S.A. & Não & Não & Não & Não & Não & Não & Não & Sim & Sim \\
\hline
\end{tabular}

Observação: N.S.A. = Não se aplica 


\subsubsection{SP0101}

Esta obra caracteriza-se pela presença de um sistema de aquecimento de água central coletivo. $\mathrm{O}$ aquecimento da água fria é feito no $1^{\circ}$ subsolo onde estão instalados os aquecedores de passagem a gás (duas unidades) para cada tanque de água quente, num total de quatro tanques para as duas torres. Para cada torre há um tanque que alimenta os pavimentos inferiores (inferiores ao $9^{\circ}$ pavimento-tipo) e outro destinado à alimentação dos pavimentos superiores (do $9^{\circ}$ ao $16^{\circ}$ pavimento-tipo) com volume de 1.000 litros cada.

Tanto os tanques destinados ao abastecimento dos pavimentos superiores quanto os destinados ao abastecimento dos pavimentos inferiores são alimentados diretamente por uma prumada específica que sai do barrilete do reservatório superior, diferindo-se apenas no fato de que, antes da alimentação destes últimos, a água fria passa por uma estação redutora de pressão.

De cada tanque parte uma prumada específica para alimentação dos pavimentos. No caso dos pavimentos inferiores, esta prumada, após alimentar estes pavimentos, prolonga-se até a cobertura constituindo o respiro do sistema. No caso dos pavimentos superiores, a prumada segue do tanque ao $8^{\circ}$ pavimento sem qualquer tipo de derivação até chegar ao $9^{\circ}$ pavimento-tipo, a partir do qual há a derivação de um ramal de distribuição interno ao apartamento para alimentação dos ambientes molháveis. Esta prumada também se estende até a cobertura constituindo-se na tubulação de respiro deste sistema.

Além das prumadas que alimentam os pavimentos com água quente, há também uma prumada que promove a circulação da água quente entre os pavimentos e os tanques de aquecimento juntamente com um ramal de distribuição de circulação existente no apartamento-tipo. Assim, em função da temperatura na tubulação, a mesma retorna 
por este ramal, passa pela prumada de retorno e chega ao sistema de aquecimento localizado no $1^{\circ}$ subsolo.

Como ponto particular, em função do comprimento dos tubos verticais que conduzem água quente e das temperaturas envolvidas, destaca-se o fato de todas as prumadas deste sistema serem providas de junta de expansão localizadas no $4^{\circ}$ ou $5^{\circ}$ pavimento (sistema baixa) e no $12^{\circ}$ ou $13^{\circ}$ (sistema alta).

Com relação ao ramal de distribuição, este tem um traçado paralelo ao da água fria, tendo-se como complemento um ramal de circulação que deriva do ramal principal na região da cozinha e alimenta a prumada de retorno localizada no shaft da área de serviço, conforme já ressaltado anteriormente.

\subsubsection{SP0201}

O sistema predial de suprimento de água quente é composto por um aquecedor de acumulação a gás com capacidade de 150 litros de água quente, alimentado por uma prumada específica. Do aquecedor, localizado na área de serviço de cada apartamento, a água quente chega até aos pontos de consumo seguindo um traçado paralelo ao de água fria (ramal de distribuição sob a laje teto). Dos ambientes molháveis, o banheiro de empregada e a área de serviço não são supridos de água quente. Nos outros ambientes, os ramais e sub-ramais são embutidos nas paredes após a colocação do isolante térmico.

\subsubsection{SP0301}

O aquecimento da água é feito individualmente em cada apartamento, com aquecedor a gás de passagem, de alta pressão e reservatório de 200 litros, instalados na área de 
serviço, que abastece os ambientes molháveis à exceção do lavabo, banheiro de empregada e a própria área de serviço.

O traçado das tubulações dentro apartamento-tipo segue a mesma concepção do sistema predial de água fria, ou seja, do aquecedor, a água quente segue por um ramal de distribuição ao lado do ramal de distribuição da água fria localizado sob a laje de teto do apartamento, desce para ambientes, geralmente junto aos seus shafts (providos de registro) e seguem por debaixo da laje de piso do apartamento até os outros pontos de consumo (aparelhos sanitários). Na cozinha, estes ramais são embutidos na parede.

\subsubsection{SP0501 e SP0801}

Os sistemas de aquecimento destas obras caracterizam-se pela presença de um aquecedor de passagem, a gás, localizado na área de serviço. A alimentação deste aquecedor é feita pelo ramal de distribuição de água fria ligado à prumada de água fria destinada também ao suprimento de água fria dos ambientes molháveis.

Do aquecedor, parte um ramal de distribuição que alimenta os banheiros social e da suíte do apartamento, posicionado paralelamente ao ramal de distribuição de água fria, abaixo da laje de teto. Nestes ambientes, a água quente chega aos pontos de consumo através de ramais e sub-ramais embutidos nas paredes. Apenas a cozinha da obra SP0801 é provida de água quente.

\subsubsection{SP0601}

O sistema de aquecimento desta obra caracteriza-se pela presença de um aquecedor de acumulação, a gás, localizado na área de serviço, com capacidade para 
armazenamento de 300 litros de água quente. A alimentação deste aquecedor é feita pelo ramal de distribuição de água fria ligado à prumada específica localizada no shaft do hall de serviço. Deste aquecedor, parte o ramal de distribuição destinado à alimentação dos banheiros das suítes e do banheiro social. A água quente chega até os pontos de consumo deste ambientes por ramais e sub-ramais embutidos nas paredes. O lavabo e banheiro de empregada não são providos de água quente enquanto que na cozinha fez-se a previsão da instalação de um aquecedor individual de passagem, a eletricidade.

\subsubsection{SP0701 e SP0702}

Os sistemas de aquecimento destas obras são semelhantes e caracterizam-se pelo uso de um aquecedor passagem, a gás, localizado na área de serviço, diferindo apenas no que diz respeito à potência e capacidade de aquecimento da água, conforme já exposto anteriormente na Tabela 5.5 .

A alimentação do aquecedor não é feita através de uma prumada específica e sim a partir do ramal de distribuição de água fria destinado à alimentação dos ambientes molháveis. Do aquecedor parte o ramal de distribuição de água quente paralelamente ao de água fria para alimentação do(s) banheiro(s) da(s) suíte(s), banheiro social e cozinha. No caso da obra SP0701, a água quente chega até os pontos de consumo nestes ambientes através de ramais e sub-ramais embutidos nas paredes e localizados sob a laje de piso, à exceção da cozinha, cujos ramais e sub-ramais são totalmente embutidos nas paredes. Já na obra SP0702, a alimentação destes ambientes é feita sob a laje de piso do apartamento. 


\subsubsection{SP0901a e SP0901b}

Esta obra utiliza também o aquecedor de passagem a gás como forma de aquecimento da água fria. Porém, ao contrário das outras obras, cuja alimentação é feita pelo ramal de distribuição localizado abaixo da laje de teto do apartamento, nesta a alimentação é feita por um ramal localizado abaixo da laje de piso. Após o aquecimento, a distribuição da água quente é feita por um ramal também localizado abaixo da laje de piso, chegando até os ambientes molháveis, no caso o banheiro social e cozinha (SP0901b) e também o banheiro da suíte (SP0901a).

\subsubsection{SP1001 e SP1002}

Os sistemas de aquecimento de água nestas obras se assemelham ao da obra SP0301. São constituídos por um aquecedor de passagem e um reservatório para armazenamento da água quente (horizontal na obra SP1001 e vertical na obra SP1002). Os aquecedores de passagem são alimentados pelo ramal de distribuição derivado de uma prumada específica. Do reservatório de água quente parte o ramal de distribuição, sob a laje de teto do apartamento, para alimentação dos ambientes molháveis. Nos ambientes molháveis, a água quente chega aos pontos de consumo através de ramais e sub-ramais embutidos nas paredes.

Como diferencial destas obras destaca-se o fato de haver também a circulação da água quente no ramal de distribuição através da sua ligação com um ramal de retorno ligando este ramal ao reservatório de água quente. 


\subsubsection{Sistema predial de suprimento de gás}

Este sistema foi previsto em todas as obras analisadas havendo diferenças no que diz respeito ao tipo de gás (gás liquefeito de petróleo ou gás natural), localização do medidor de consumo, número e localização de prumadas no pavimento-tipo.

Das obras analisadas somente a SP0401 utiliza gás liquefeito de petróleo (GLP) enquanto as demais, talvez por se localizarem na capital paulistana, utilizam o gás natural. Quanto à posição das prumadas, em duas das obras observou-se que as prumadas de gás são aparentes, enquanto que nas demais, as prumadas foram enclausuradas nas paredes dos shafts presentes na área de serviço ou entre este ambiente e a cozinha e no hall de serviço. Em todas as obras verificou-se a presença de uma prumada exclusiva para cada apartamento-tipo, à exceção da obra SP0401 onde o ramal de distribuição dos quatro apartamentos-tipo deriva de uma única prumada localizada no shaft do hall de serviço. Observou-se também que os ramais de distribuição destinados à alimentação do aquecedor e fogão seguiam enclausurados no contrapiso e nas paredes em algumas obras (principalmente naquelas onde a prumada se localiza no hall de serviço) e, em outras, enclausurados somente nas paredes.

Em todas as obras está previsto um sistema de medição individualizada de consumo de gás, seja ele remoto (nas obras em que este sistema se localiza dentro do apartamento-tipo) ou in loco (nas obras em que este sistema se localiza fora do apartamento-tipo, mais especificamente, no hall de serviço). Nas obras em que este sistema se localiza no hall de serviço fez-se a previsão de uma prumada de ventilação ao longo dos pavimentos. Nas demais, a ventilação se deu com aberturas no próprio ambiente de acordo com as prescrições da NBR 13103 (ABNT, 2006). As principais características apontadas para este sistema estão reunidas na Tabela 5.6. 
Tabela 5.6 - Resumo das características do sistema predial de suprimento de gás das obras analisadas

\begin{tabular}{|c|c|c|c|c|c|c|c|c|c|c|c|c|c|}
\hline CARACTERÍSTICAS & SP0101 & SP0201 & SP0301 & SP0401 & SP0501 & SP0601 & SP0701 & SP0702 & SP0801 & SP0901a & SP0901b & SP1001 & SP1002 \\
\hline Tipo & $\begin{array}{l}\text { Gás } \\
\text { Natural }\end{array}$ & $\begin{array}{l}\text { Gás } \\
\text { Natural }\end{array}$ & $\begin{array}{l}\text { Gás } \\
\text { Natural }\end{array}$ & $\begin{array}{c}\text { Gás } \\
\text { Liquefeito } \\
\text { de } \\
\text { Petróleo }\end{array}$ & $\begin{array}{l}\text { Gás } \\
\text { Natural }\end{array}$ & $\begin{array}{c}\text { Gás } \\
\text { Natural }\end{array}$ & $\begin{array}{l}\text { Gás } \\
\text { Natural }\end{array}$ & $\begin{array}{l}\text { Gás } \\
\text { Natural }\end{array}$ & $\begin{array}{c}\text { Gás } \\
\text { Natural }\end{array}$ & $\begin{array}{l}\text { Gás } \\
\text { Natural }\end{array}$ & $\begin{array}{l}\text { Gás } \\
\text { Natural }\end{array}$ & $\begin{array}{l}\text { Gás } \\
\text { Natural }\end{array}$ & $\begin{array}{l}\text { Gás } \\
\text { Natural }\end{array}$ \\
\hline $\begin{array}{l}\text { Localização da } \\
\text { prumada }\end{array}$ & $\begin{array}{c}\text { Enclausu- } \\
\text { rada no } \\
\text { shaft da } \\
\text { área de } \\
\text { serviço }\end{array}$ & $\begin{array}{c}\text { Enclausu- } \\
\text { rada na } \\
\text { parede do } \\
\text { shaft } \\
\text { existente } \\
\text { entre a } \\
\text { cozinha e } \\
\text { área de } \\
\text { serviço }\end{array}$ & $\begin{array}{c}\text { Enclausu- } \\
\text { rada na } \\
\text { parede do } \\
\text { shaft } \\
\text { existente } \\
\text { entre a } \\
\text { cozinha e } \\
\text { área de } \\
\text { serviço }\end{array}$ & $\begin{array}{c}\text { Enclausu- } \\
\text { rada no } \\
\text { shaft do } \\
\text { hall de } \\
\text { serviço }\end{array}$ & $\begin{array}{l}\text { Aparente } \\
\text { localizada } \\
\text { junto à } \\
\text { face } \\
\text { externa da } \\
\text { parede do } \\
\text { dormitório }\end{array}$ & $\begin{array}{c}\text { Enclausu- } \\
\text { rada na } \\
\text { parede do } \\
\text { shaft } \\
\text { existente } \\
\text { entre a } \\
\text { cozinha e } \\
\text { área de } \\
\text { serviço }\end{array}$ & $\begin{array}{l}\text { Aparente } \\
\text { localizada } \\
\text { junto à } \\
\text { face } \\
\text { externa da } \\
\text { parede da } \\
\text { área de } \\
\text { serviço }\end{array}$ & $\begin{array}{c}\text { Enclausu- } \\
\text { rada no } \\
\text { shaft do } \\
\text { hall de } \\
\text { serviço }\end{array}$ & $\begin{array}{c}\text { Enclausu- } \\
\text { rada na } \\
\text { parede do } \\
\text { shaft } \\
\text { existente } \\
\text { entre a } \\
\text { cozinha e } \\
\text { área de } \\
\text { serviço }\end{array}$ & $\begin{array}{l}\text { Localizada } \\
\text { junto à } \\
\text { face } \\
\text { externa da } \\
\text { parede da } \\
\text { área de } \\
\text { serviço, } \\
\text { porém, } \\
\text { enclausu- } \\
\text { rada } \\
\end{array}$ & $\begin{array}{l}\text { Localizada } \\
\text { junto à } \\
\text { face } \\
\text { externa da } \\
\text { parede da } \\
\text { área de } \\
\text { serviço, } \\
\text { porém, } \\
\text { enclausu- } \\
\text { rada }\end{array}$ & $\begin{array}{c}\text { Enclausu- } \\
\text { rada junto } \\
\text { à parede } \\
\text { divisória } \\
\text { da área de } \\
\text { serviço e } \\
\text { cozinha }\end{array}$ & $\begin{array}{c}\text { Enclausu- } \\
\text { rada junto } \\
\text { à parede } \\
\text { divisória } \\
\text { da área de } \\
\text { serviço e } \\
\text { dormitório }\end{array}$ \\
\hline $\begin{array}{l}\text { Prumada única para } \\
\text { cada apartamento }\end{array}$ & Sim & Sim & Sim & Não & Sim & $\mathrm{Sim}^{31}$ & Sim & Não & Sim & Sim & Sim & $\mathrm{Sim}^{2}$ & Sim \\
\hline Medição remota & Sim & Sim & Sim & Não & Sim & Sim & Sim & Não & Sim & Sim & Sim & Sim & Sim \\
\hline $\begin{array}{l}\text { Localização do medidor } \\
\text { de gás }\end{array}$ & $\begin{array}{l}\text { Área de } \\
\text { serviço }\end{array}$ & $\begin{array}{l}\text { Área de } \\
\text { serviço }\end{array}$ & $\begin{array}{l}\text { Área de } \\
\text { serviço }\end{array}$ & $\begin{array}{l}\text { Hall de } \\
\text { serviço }\end{array}$ & $\begin{array}{l}\text { Área de } \\
\text { serviço }\end{array}$ & $\begin{array}{l}\text { Área de } \\
\text { serviço }\end{array}$ & $\begin{array}{l}\text { Área de } \\
\text { serviço }\end{array}$ & $\begin{array}{l}\text { Hall de } \\
\text { serviço }\end{array}$ & $\begin{array}{l}\text { Área de } \\
\text { serviço }\end{array}$ & $\begin{array}{l}\text { Área de } \\
\text { serviço }\end{array}$ & $\begin{array}{l}\text { Área de } \\
\text { serviço }\end{array}$ & $\begin{array}{l}\text { Área de } \\
\text { serviço }\end{array}$ & $\begin{array}{l}\text { Área de } \\
\text { serviço }\end{array}$ \\
\hline $\begin{array}{l}\text { Diâmetro da tubulação } \\
\text { da prumada }(\mathrm{mm})\end{array}$ & $\begin{array}{c}\text { Variável } \\
(66,54 \text { e } \\
42)\end{array}$ & $\begin{array}{c}\text { Variável } \\
(66,54 \text { e } \\
42)\end{array}$ & $\begin{array}{c}\text { Variável } \\
(66,54 \text { e } \\
42)\end{array}$ & 54 & $\begin{array}{l}\text { Variável } \\
\text { (66 e } 54)\end{array}$ & $\begin{array}{l}\text { Variável } \\
(54,42, \\
35 \text { e } 28)\end{array}$ & $\begin{array}{c}\text { Variável } \\
(66,54 \text { e } \\
28)\end{array}$ & $\begin{array}{c}\text { Variável } \\
(79,66, \\
54,42 \text { e } \\
35)\end{array}$ & $\begin{array}{c}\text { Variável } \\
(66,54 \text { e } \\
42)\end{array}$ & $\begin{array}{l}\text { Variável } \\
(66,54 \\
42 \text { e } 28)\end{array}$ & $\begin{array}{l}\text { Variável } \\
(66,54 \\
42 \text { e } 28)\end{array}$ & $\begin{array}{c}\text { Variável } \\
(66,54, \\
42,35 \text { e } \\
28)\end{array}$ & $\begin{array}{l}\text { Variável } \\
(54,42, \\
35 \text { e } 28)\end{array}$ \\
\hline $\begin{array}{l}\text { Posição das tubulações } \\
\text { dos ramais }\end{array}$ & Parede & $\begin{array}{l}\text { Contrapi- } \\
\text { so e } \\
\text { parede }\end{array}$ & $\begin{array}{l}\text { Contrapi- } \\
\text { so e } \\
\text { parede }\end{array}$ & $\begin{array}{l}\text { Contrapi- } \\
\text { so e } \\
\text { parede }\end{array}$ & Parede & $\begin{array}{l}\text { Contrapi- } \\
\text { so e } \\
\text { parede }\end{array}$ & Parede & $\begin{array}{l}\text { Contrapi- } \\
\text { so e } \\
\text { parede }\end{array}$ & Parede & $\begin{array}{l}\text { Contrapi- } \\
\text { so e } \\
\text { parede }\end{array}$ & $\begin{array}{l}\text { Contrapi- } \\
\text { so e } \\
\text { parede }\end{array}$ & Parede & $\begin{array}{l}\text { Parede e } \\
\text { piso }\end{array}$ \\
\hline
\end{tabular}

\footnotetext{
${ }^{31}$ Um apartamento por andar
} 


\subsubsection{Sistema predial de coleta de esgoto sanitário}

Os tubos de queda de esgoto estão distribuídos pelos shafts existentes no pavimentotipo, sendo providos ou não de ventilação secundária.

Em todas as obras verificou-se que os tubos de queda destinados ao escoamento do esgoto proveniente da cozinha e área de serviço são providos apenas de ventilação primária, ou seja, do prolongamento do tubo de queda acima do nível da cobertura.

No que diz respeito ao escoamento do esgoto proveniente da área de serviço (ralo, tanque e máquina de lavar roupa), verificou-se adoção de tubos de queda independentes para o esgoto espumoso proveniente da máquina de lavar roupa e do(s) tanque(s).

Para evitar o transbordo de espuma nos pontos de captação localizados na área de serviço dos pavimentos inferiores, em algumas obras foram previstos tubos de queda específicos para coletar o esgoto destes pavimentos, variando com relação ao pavimento a partir do qual esta coleta é efetuada.

Em alguns casos, este tubo de queda complementar não foi previsto. Mas nestes casos, o esgoto proveniente do ralo presente na área de serviço foi destinado para um tubo de queda distinto ao do escoamento do esgoto da máquina de lavar roupa e tanque(s).

No que diz respeito aos tubos de queda destinados ao escoamento dos esgotos dos banheiros e lavabos, estes foram providos de ventilação secundária. Em alguns casos, esta ventilação era feita através do ramal de ventilação e, em outros, através da comunicação direta da coluna de ventilação com o tubo de queda.

Ainda com relação a estes tubos de queda, alguns foram projetados para garantir o escoamento do esgoto de mais de um ambiente. Como exemplos, citam-se a obra 
SP0401 (tubo de queda servindo tanto o banheiro social quanto o banheiro da suíte), a obra SP0201 (tubo de queda servindo os banheiros das suítes 1 e 2 e tubo de queda servindo o banheiro da suíte 1 e lavabo) entre outras.

Finalmente, foram previstos tubos de queda para o escoamento do esgoto proveniente das pias localizadas nos terraços das obras providas de churrasqueira. Nestes casos, os tubos de queda são providos apenas de ventilação primária.

As principais características deste sistema predial estão reunidas na Tabela 5.7. 
Tabela 5.7 - Resumo das características do sistema predial de esgoto sanitário das obras analisadas

\begin{tabular}{|c|c|c|c|c|c|c|c|c|c|c|c|c|c|}
\hline CARACTERÍSTICAS & SP0101 & SP0201 & SP0301 & SP0401 & SP0501 & SP0601 & SP0701 & SP0702 & SP0801 & SP0901a & SP0901b & SP1001 & SP1002 \\
\hline $\begin{array}{l}\text { Número de tubos de } \\
\text { queda por apartamento }\end{array}$ & 8 & 6 & 8 & 3 & 5 & 9 & 8 & 8 & 6 & 4 & 3 & 6 & 7 \\
\hline $\begin{array}{l}\text { Número de tubos de } \\
\text { queda somente com } \\
\text { ventilação primária }\end{array}$ & 3 & 3 & 3 & 2 & 2 & 4 & 4 & 2 & 3 & 1 & 2 & 2 & 3 \\
\hline $\begin{array}{l}\text { Número de tubos de } \\
\text { queda com ventilação } \\
\text { primária e secundária }\end{array}$ & 5 & 3 & 5 & 1 & 3 & 5 & 4 & 6 & 3 & 13 & 1 & 4 & 4 \\
\hline $\begin{array}{l}\text { Número de tubos de } \\
\text { queda com ventilação } \\
\text { secundária por ramais }\end{array}$ & 1 & 3 & 5 & 1 & 3 & 5 & 4 & 6 & 2 & 3 & 1 & 4 & 0 \\
\hline $\begin{array}{l}\text { Número de tubos de } \\
\text { queda com ventilação } \\
\text { secundária diretamente } \\
\text { no tubo de queda }\end{array}$ & 4 & 0 & 0 & 0 & 0 & 0 & 0 & 0 & 1 & 0 & 0 & 0 & 4 \\
\hline $\begin{array}{l}\text { Número de tubos de } \\
\text { queda que recebe } \\
\text { esgoto de mais de um } \\
\text { ambiente }\end{array}$ & 0 & 2 & 0 & 1 & 0 & 0 & 1 & 2 & 1 & 1 & 0 & 2 & 2 \\
\hline $\begin{array}{l}\text { Coluna de ventilação } \\
\text { comum a mais de um } \\
\text { tubo de queda }\end{array}$ & 0 & 0 & 1 & 0 & 0 & 0 & 0 & 0 & 0 & 0 & 0 & 0 & 0 \\
\hline $\begin{array}{l}\text { Tubo de queda para } \\
\text { captar esgoto } \\
\text { espumoso dos } \\
\text { pavimentos inferiores }\end{array}$ & $\begin{array}{l}\text { A partir } \\
\text { do } 3^{\circ} \\
\text { pav.-tipo }\end{array}$ & $\begin{array}{l}\text { A partir } \\
\text { do } 4^{\circ} \\
\text { pav.-tipo }\end{array}$ & $\begin{array}{l}\text { A partir } \\
\text { do } 1^{\circ} \\
\text { pav.-tipo }\end{array}$ & N.I & Não & $\begin{array}{l}\text { A partir } \\
\text { do } 4^{\circ} \\
\text { pav.-tipo }\end{array}$ & Não & $\begin{array}{l}\text { A partir } \\
\text { do } 4^{\circ} \\
\text { pav.-tipo }\end{array}$ & Não & N.I. & N.I. & $\begin{array}{l}\text { A partir } \\
\text { do } 1^{\circ} \\
\text { pav.-tipo }\end{array}$ & $\begin{array}{l}\text { A partir } \\
\text { do } 1^{\circ} \\
\text { pav.-tipo }\end{array}$ \\
\hline
\end{tabular}

Observação: N.I = Não identificado no projeto. 
Tabela 5.7 - Resumo das características do sistema predial de esgoto sanitário das obras analisadas (continuação)

\begin{tabular}{|c|c|c|c|c|c|c|c|c|c|c|c|c|c|}
\hline CARACTERÍSTICAS & SP0101 & SP0201 & SP0301 & SP0401 & SP0501 & SP0601 & SP0701 & SP0702 & SP0801 & SP0901a & SP0901b & SP1001 & SP1002 \\
\hline $\begin{array}{l}\text { Tubo de queda no } \\
\text { terraço (pia da } \\
\text { churrasqueira)? }\end{array}$ & Não & Sim & Não & Não & Não & Sim & Não & Não & Não & Não & Não & Não & Não \\
\hline $\begin{array}{l}\text { Esgoto da máquina de } \\
\text { lavar roupas e } \\
\text { tanque(s) segue para o } \\
\text { mesmo tubo de queda? }\end{array}$ & Sim & Sim & Não & Sim & Sim & Sim & Não & Não & Não & Sim & Sim & Sim & Sim \\
\hline $\begin{array}{l}\text { Esgoto proveniente do } \\
\text { ralo da área de serviço } \\
\text { é escoado pelo mesmo } \\
\text { tubo de queda } \\
\text { destinado ao esgoto da } \\
\text { máquina de lavar } \\
\text { roupas e(ou) } \\
\text { tanque(s)? }\end{array}$ & Não & Não & Não & Não & Não & Não & Não & Não & Sim & Não & Sim & Não & Não \\
\hline $\begin{array}{l}\text { Ângulo da junção entre } \\
\text { ramal de esgoto e tubo } \\
\text { de queda }\end{array}$ & $45^{\circ}$ & $90^{\circ}$ & $45^{\circ}$ & $90^{\circ}$ & $90^{\circ}$ & $90^{\circ}$ & $45^{\circ}$ & $45^{\circ}$ & $90^{\circ}$ & $90^{\circ}$ & $90^{\circ}$ & $45^{\circ}$ & $45^{\circ}$ \\
\hline
\end{tabular}




\subsubsection{Sistema predial de coleta de águas pluviais}

Como característica principal deste sistema destaca-se o fato de, em todas as obras, não existir telhado, a não ser em regiões localizadas em algumas delas. Desta forma, nenhum tubo de queda de escoamento de águas pluviais é aparente, ou seja, não corre junto à fachada e sim dentro de shafts distribuídos ao longo dos pavimentos.

Dentre os tubos de queda observados, alguns captam água exclusivamente dos pavimentos superiores (cobertura, ático e eventualmente duplex superior) e a encaminham diretamente para os coletores e subcoletores localizados abaixo da laje de teto do $1^{\circ}$ subsolo que a conduzem até caixas de inspeção e, posteriormente, para o passeio.

Outros, além da captação das águas pluviais provenientes destes pavimentos, servem também para a captação das águas pluviais provenientes dos terraços existentes nos pavimentos-tipo.

Finalmente, há também casos em que os tubos de queda se destinam apenas à captação de águas pluviais destes terraços, havendo situações em que se adota um único tubo de queda para captar as águas pluviais de dois terraços simultaneamente, ou tubos de queda independentes para cada terraço, mesmo nos casos em que se tenham terraços contíguos. A caracterização deste sistema é apresentada na Tabela 5.8. 
Tabela 5.8 - Resumo das características do sistema predial de escoamento de águas pluviais das obras analisadas

\begin{tabular}{|c|c|c|c|c|c|c|c|c|c|c|c|c|c|}
\hline CARACTERÍSTICAS & SP0101 & SP0201 & SP0301 & SP0401 & SP0501 & SP0601 & SP0701 & SP0702 & SP0801 & SP0901a & SP0901b & SP1001 & SP1002 \\
\hline $\begin{array}{l}\text { Número total de tubos } \\
\text { de queda }\end{array}$ & 5 & 4 & 6 & 3 & 3 & 8 & 6 & 4 & 3 & 4 & 2 & 7 & 6 \\
\hline $\begin{array}{l}\text { Número de tubos de } \\
\text { queda localizados nos } \\
\text { shafts do apartamento- } \\
\text { tipo }\end{array}$ & 5 & 2 & 6 & 3 & 3 & 8 & 5 & 4 & 3 & 3 & 1 & 6 & 6 \\
\hline $\begin{array}{l}\text { Número de tubos de } \\
\text { queda localizados no(s) } \\
\text { shaft(s) da área comum } \\
\text { (hall de serviço, por } \\
\text { exemplo) }\end{array}$ & 0 & 2 & 0 & 0 & 0 & 0 & 1 & 0 & 0 & 1 & 1 & 1 & 0 \\
\hline $\begin{array}{l}\text { Número de tubos de } \\
\text { queda destinados à } \\
\text { captação de água } \\
\text { pluvial da } \\
\text { cobertura/ático }\end{array}$ & 3 & 3 & 3 & 2 & 2 & 4 & 4 & 2 & 2 & 3 & 1 & 3 & 2 \\
\hline $\begin{array}{l}\text { Número de tubos de } \\
\text { queda destinados } \\
\text { exclusivamente à } \\
\text { captação de água } \\
\text { pluvial do(s) terraço(s) }\end{array}$ & 2 & 0 & 2 & 1 & 1 & 4 & 2 & 1 & 1 & 1 & 1 & 4 & 3 \\
\hline $\begin{array}{l}\text { Número de tubos de } \\
\text { queda destinados à } \\
\text { captação de água } \\
\text { pluvial da } \\
\text { cobertura/atiço e do(s) } \\
\text { terraço(s) }\end{array}$ & 0 & 1 & 1 & 0 & 0 & 0 & 0 & 0 & 0 & 0 & 0 & 0 & 1 \\
\hline
\end{tabular}


Tabela 5.8 - Resumo das características do sistema predial de escoamento de águas pluviais das obras analisadas (continuação)

\begin{tabular}{|c|c|c|c|c|c|c|c|c|c|c|c|c|c|}
\hline CARACTERÍSTICAS & SP0101 & SP0201 & SP0301 & SP0401 & SP0501 & SP0601 & SP0701 & SP0702 & SP0801 & SP0901a & SP0901b & SP1001 & SP1002 \\
\hline $\begin{array}{l}\text { Tubo de queda comum } \\
\text { a mais de um terraço? }\end{array}$ & Não & Não & Não & $\mathrm{Sim}^{32}$ & $\mathrm{Sim}^{33}$ & Não & Não & Sim & Não & $\mathrm{Sim}^{34}$ & Não & Não & $\mathrm{Sim}^{3}$ \\
\hline $\begin{array}{l}\text { Terraço com grelha } \\
(\mathrm{S}, \mathrm{N}) ?\end{array}$ & Não & Não & Não & Não & Não & Sim & Não & Não & Não & Não & Não & Não & Não \\
\hline
\end{tabular}

${ }^{32}$ Em dois tubos de queda (terraço e duplex inferior)

34 Terraço

Cobertura

$\vec{\oplus}$ 


\subsubsection{Sistema predial de prevenção e combate a incêndios}

Todas as obras são providas de hidrantes, extintores manuais, além de outros sistemas de prevenção e combate a incêndios previstos no Decreto nº. 46.076 do Corpo de Bombeiros da cidade de São Paulo, tais como iluminação e saídas de emergência.

O primeiro sistema (hidrantes), de interesse deste trabalho, é compreendido por uma tubulação que sai da laje de fundo do reservatório superior, passa por um sistema de pressurização existente na cobertura, com o objetivo de garantir a pressão mínima nos pavimentos nos quais não se consegue garanti-la somente por gravidade, e desce junto ao shaft existente, geralmente no hall de serviço, e prolonga-se até o registro de recalque situado no passeio. Em cada pavimento-tipo há um hidrante localizado na área de circulação, com comprimento de mangueira variável de obra para obra. Em particular, a obra SP0901 possui dois hidrantes em cada pavimento-tipo, enquanto que nas demais há apenas um. 


\subsection{Caracterização da execução dos serviços}

Neste item é feita a caracterização da execução dos serviços das obras onde se realizou o estudo da produtividade da mão-de-obra. São abordadas a seqüência de execução, as principais atividades desenvolvidas pela equipe executora e as técnicas utilizadas. Pela extensão das atividades (tarefas) desenvolvidas pelas equipes executoras, optou-se em resumir apenas àquelas em que o levantamento da produtividade da mão-de-obra foi realizado, e eventualmente outras consideradas relevantes para o entendimento da execução dos serviços.

\subsubsection{Estocagem e transporte}

O estoque de tubos de PVC da obra SP0101 era feito no pavimento térreo, em uma posição intermediária entre as duas torres, sendo de livre acesso aos operários (Figura 5.7a) enquanto que os tubos de cobre eram armazenados em prateleiras de madeira em um almoxarifado fechado, com acesso restrito aos operários, porém sem a presença de um almoxarife. Já as conexões e acessórios foram armazenados em outro local e sua retirada era controlada por um almoxarife da empresa construtora.

Na obra SP0201, o estoque de tubos, tanto de cobre quanto de PVC se localizava no pavimento térreo (Figura 5.7b), junto à sala destinada à subempreiteira responsável pela execução dos sistemas prediais. Já as conexões e acessórios ficavam estocados na sala da subempreiteira, cujo acesso era permitido apenas aos operários desta.

A estocagem de todos os componentes utilizados na execução dos sistemas prediais da obra SP0301 foi feita na sala da subempreiteira contratada localizada no $1^{\circ}$ subsolo (Figura 5.7c). Já na obra SP0401, a estocagem dos tubos de PVC e de cobre foi feita 
no pavimento térreo, ao lado do almoxarifado central, onde eram estocados os acessórios e as conexões e (Figura 5.7d).

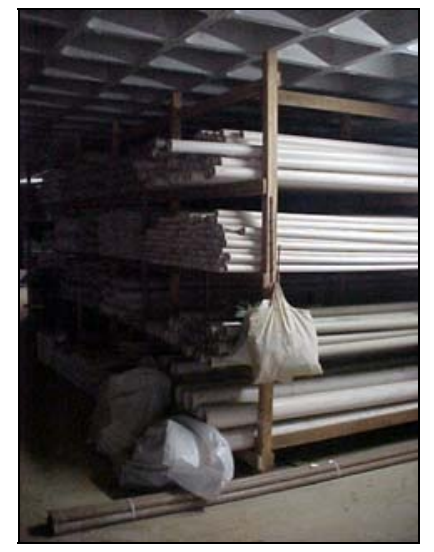

(a)

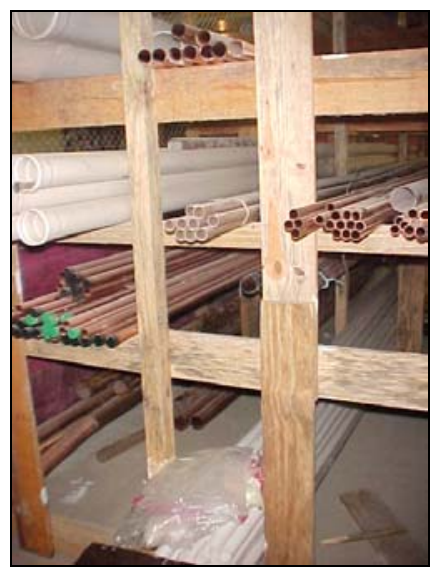

(c)

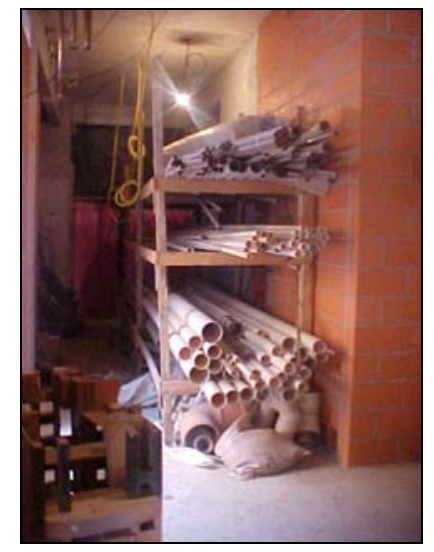

(b)

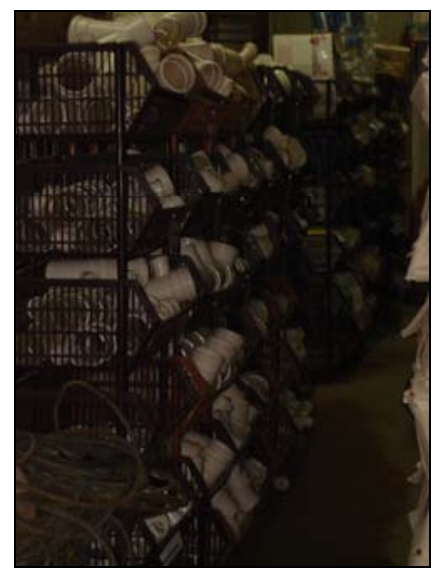

(d)

Figura 5.7 - Estocagem dos componentes utilizados na execução dos sistemas prediais: (a) Estoque de tubos - SP0101; (b) Estoque de tubos - SP0201; (c) Estoque de tubos SP0301; (d) Estoque de conexões - SP0401

Em todas as obras os tubos eram transportados pelo elevador de cargas até o pavimento pela própria equipe de trabalho. No início do dia, cada equipe, a partir da distribuição de serviços efetuada pelo encarregado se encaminhava para os locais de estocagem para a retirada do material necessário. Não havia uma regra quanto à quantidade a ser retirada (quantidade para um dia ou vários dias de trabalho, 
quantidade para um pavimento ou vários pavimentos). Diante da inexistência desta regra, observou-se em alguns casos, o transporte de componentes entre pavimentos. As sobras de tubos de PVC eram colocadas em um cercado feito de madeira compensada localizado ao lado do estoque de tubos na obra SP0101 (Figura 5.8a), enquanto que as sobras dos tubos de cobre eram armazenadas em tambores localizados junto ao estoque destes (Figura 5.8b).

Na obra SP0201, as sobras de PVC eram jogadas diretamente na caçamba de entulho estacionada em frente da obra, enquanto que as sobras de cobre eram transportadas diretamente para a sala da subempreiteira.

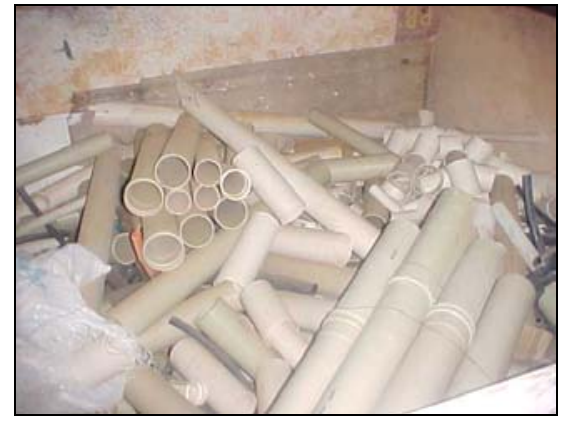

(a)

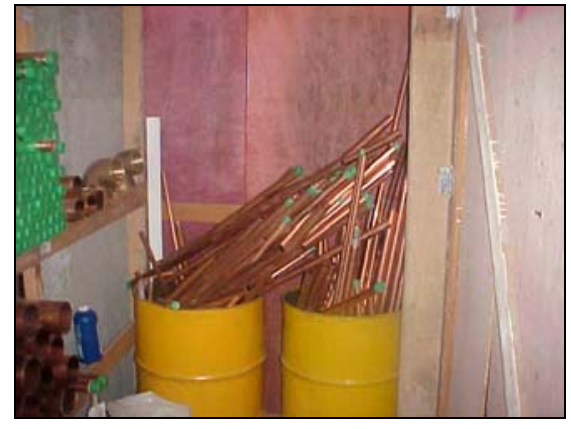

(b)

Figura 5.8 - Sobras de tubos - SP0101: (a) PVC; (b) Cobre

\subsubsection{Método executivo}

\subsubsection{SP0101}

\section{Corte e rasgo de paredes}

Após o prévio chapiscamento das paredes, a demarcação da área de parede a ser cortada e rasgada foi feita com auxílio de uma régua com nível de bolha e um prego. Após esta demarcação, realizou-se o corte utilizando-se uma serra de corte com disco 
adiamantado. O rasgo, por sua vez, foi realizado manualmente com auxílio de talhadeira de marreta. Na Figura 5.9 pode-se observar as fases deste processo.

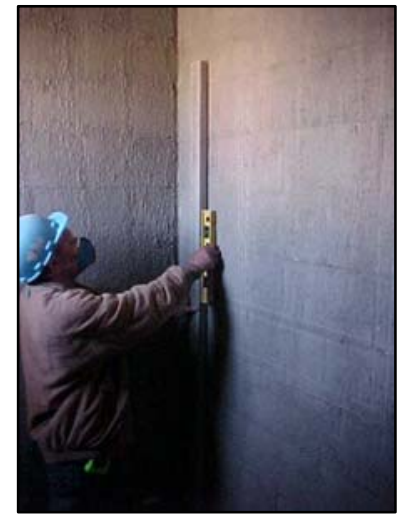

(a)

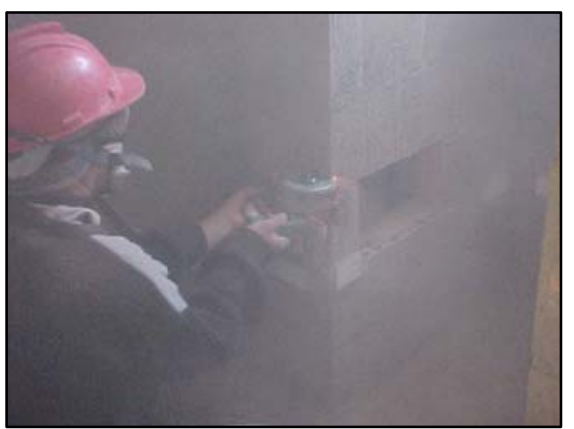

(c)

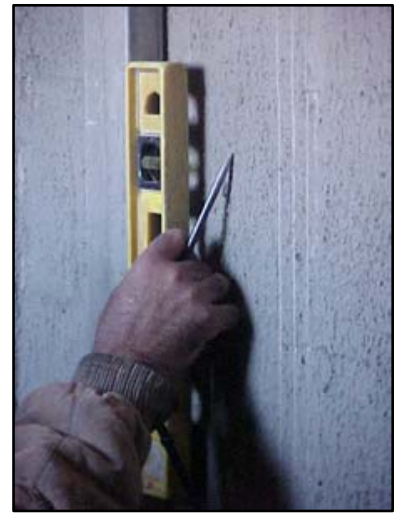

(b)

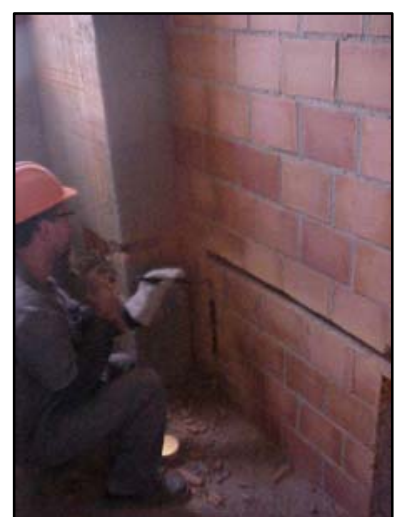

(d)

Figura 5.9 - Marcação e corte das paredes para embutimento das instalações - SP0101: (a) e (b) execução do risco no prumo; (c) execução do corte das paredes; (d) execução dos rasgos nas paredes

\section{Produção de kits}

Algumas partes das instalações de cobre, principalmente aquelas providas de componentes roscáveis (registro de pressão e misturadores, por exemplo), foram produzidas em uma central de produção localizada próxima ao local de estocagem dos 
tubos de PVC e cobre (Figura 5.10a). A partir de uma análise dos projetos, o encarregado determinou os kits a serem produzidos, sendo na sua maioria, constituídos por ramais de água fria, água quente e gás, principalmente aqueles que derivam do ramal de distribuição (figuras 5.10b e 5.10c).
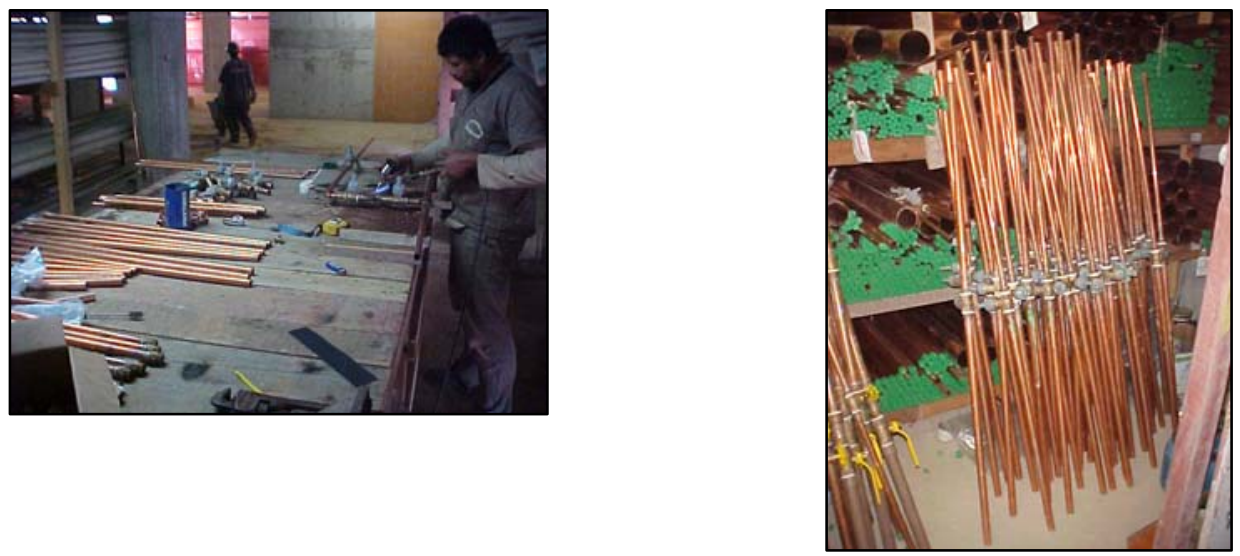

(a)

(b)

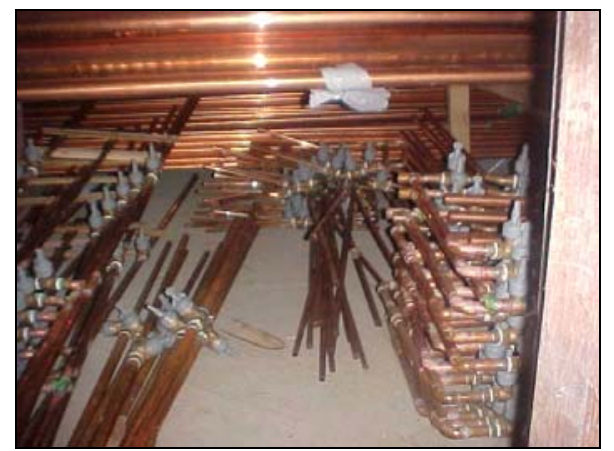

(c)

Figura 5.10 - Produção de kits de instalações - SP0101: (a) operário trabalhando na bancada na produção de kits (b) e (c) kits produzidos e estocados em sala reservada 


\section{Prumadas de água fria, água quente, gás e incêndio}

Durante a concretagem das lajes dos pavimentos foram previstos blocos de isopor como forma de delimitar a região dos shafts. Após sua retirada pela equipe executora dos sistemas prediais, iniciou-se a montagem das tubulações das prumadas.

No caso desta obra, as tubulações de cobre se localizavam apenas no shaft entre a área de serviço e cozinha de cada apartamento (prumadas de água fria, gás e incêndio) e no shaft do hall de serviço (tubulação de recalque, incêndio). Como ponto particular desta obra em relação às demais em que o estudo sobre a produtividade da mão-de-obra foi realizado consiste na presença de juntas de expansão em determinados pontos ao longo das prumadas de água quente.

Imediatamente após a montagem ou ao final do dia, a equipe executora providenciava a fixação das tubulações junto a um perfil metálico fixado na parede de fundo do shaft utilizando braçadeiras. Após a montagem das tubulações num certo conjunto de pavimentos, a equipe retornava aos pavimentos inferiores para a vedação horizontal dos shafts, preenchendo o espaço com argamassa a fim de promover o isolamento vertical entre as unidades.

Cabe salientar que, com o intuito de evitar a corrosão galvânica entre o metal da braçadeira e o tubo de cobre, a equipe utilizava um anel de PVC como isolante. Nas prumadas de água quente, a equipe já colocava o isolante térmico neste trecho para desempenhar esta função. A colocação do isolante térmico, por sua vez, em toda a extensão da prumada de água quente era feita por outra equipe e em outro momento. Na Figura 5.11 ilustra-se o processo descrito anteriormente. 

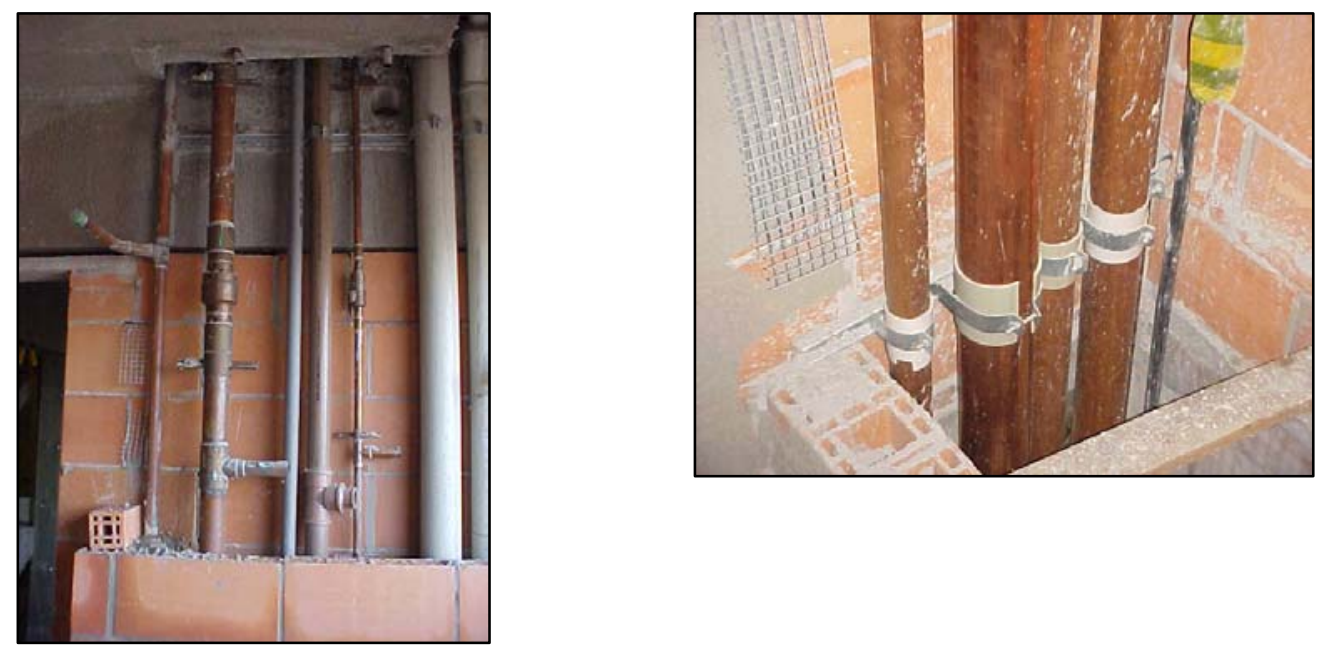

(a)

(b)

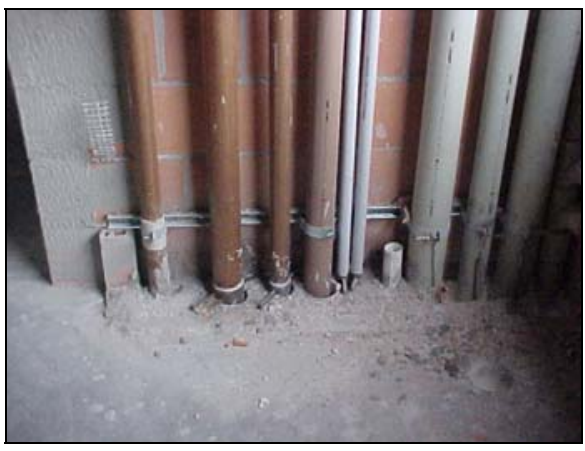

(c)

Figura 5.11 - Execução das prumadas - SP0101: (a) vista das prumadas do shaft da área de serviço (b) vista das prumadas do shaft do hall de serviço com detalhe para a proteção entre a braçadeira e as tubulações de cobre; (c) Prumadas fixadas e chumbadas no shaft

Ramais de distribuição: água quente e água fria

Os ramais de distribuição de água fria e água quente junto à laje de teto do apartamento foram fixados individualmente por meio de fitas Walsywa fixadas 
diretamente na laje com uso de pino e revolver de pressão e espaçadas de acordo com as especificações constantes no projeto.

Inicialmente, os operários fixavam todas as fitas ao longo do trajeto das tubulações. Feito isto, retornavam ao ponto inicial para a colocação e montagem simultânea das tubulações em cada trecho. Antes da colocação da tubulação do ramal de distribuição de água quente, esta já era revestida em grande parte pelo isolante térmico, sendo apenas as pontas da tubulação desprovidas deste em função da solda com as conexões. Ao término da montagem, retornavam para a complementação dos trechos com o isolante térmico.

Quando tarefados, os operários adotavam outra postura com relação à montagem. Em vez de realizarem a colocação e montagem simultânea da tubulação, optaram inicialmente por distribuir as tubulações ao longo de todo o trajeto para, em seguida, retornarem ao trecho inicial fazendo a montagem destas, ou seja, conectando os tubos.

Caso os ramais verticais de água fria e água quente já se encontravam embutidos na parede dos ambientes, os operários responsáveis pela execução dos ramais de distribuição já faziam a ligação com os mesmos. Caso contrário, posteriormente um outro operário fazia esta complementação no momento em que executava os ramais e sub-ramais localizados sob a laje de piso do apartamento. Na Figura 5.12 pode-se observar as fases deste processo. 


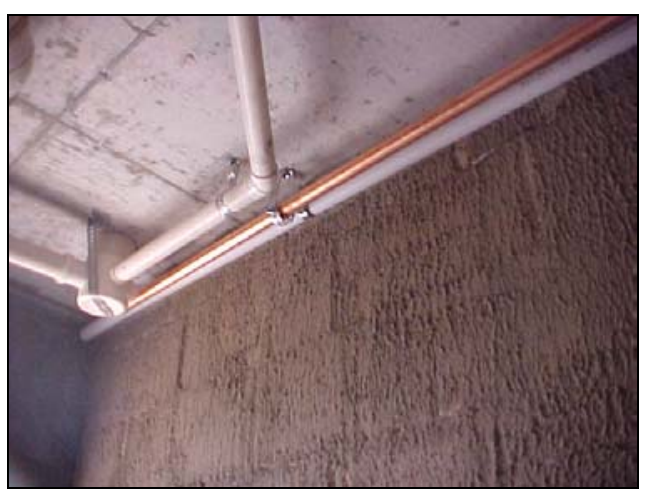

(a)

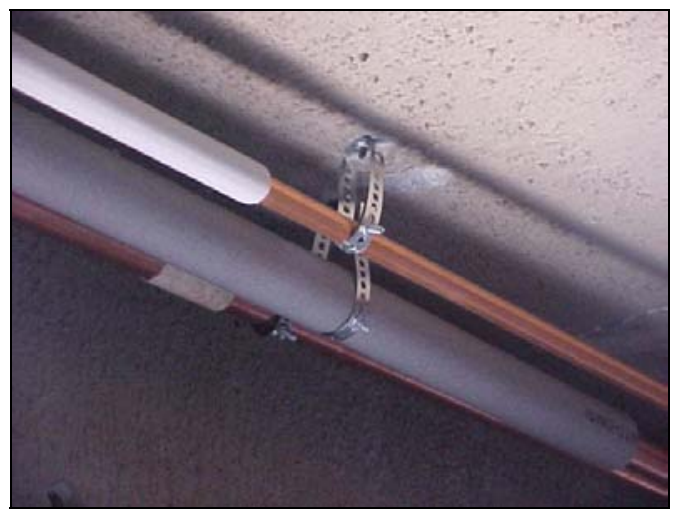

(c)

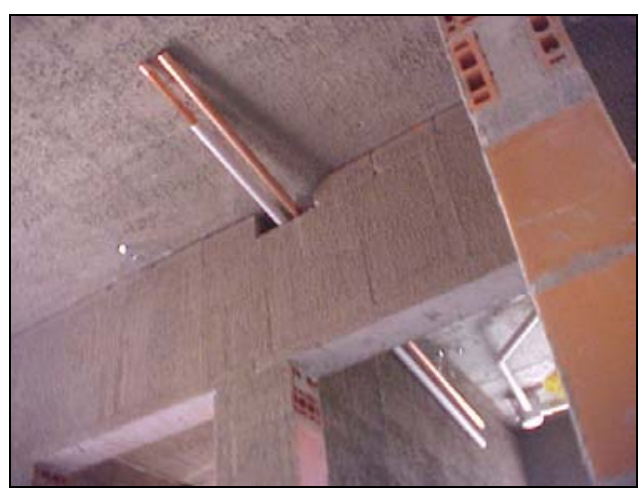

(b)

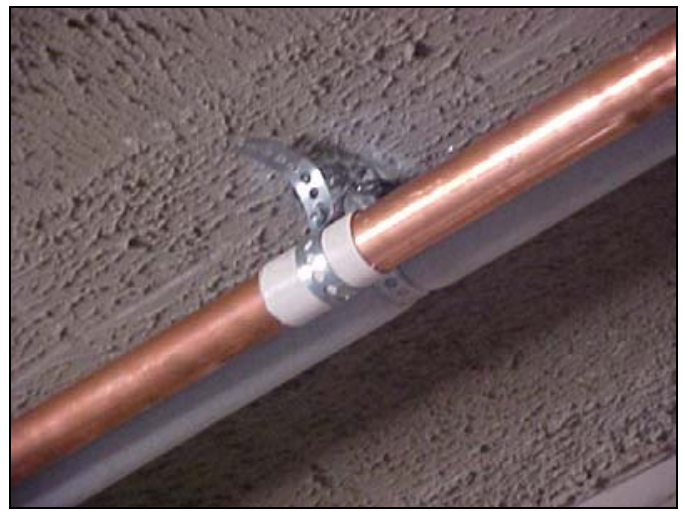

(d)

Figura 5.12 - Execução dos ramais de distribuição de água fria e água quente - SP0101: (a) tubulações fixadas junto à laje de teto do apartamento (b) tubulações posicionadas sobre a alvenaria para posterior montagem; (c) e (d) detalhe da fixação das tubulações na laje de teto do apartamento

\section{Ramais e sub-ramais: gás, água quente e água fria}

Após o corte e rasgo das paredes, os operários iniciavam a montagem dos ramais e sub-ramais que, por concepção de projeto, se estendiam também sob a laje de piso do apartamento até os pontos de consumo.

Assim, havia uma divisão clara deste serviço: uma equipe de operários se encarregava da execução dos ramais e sub-ramais sob a laje, enquanto outra se 
dedicava aos embutidos nas paredes. No que diz respeito a estes últimos, havia ainda uma distinção quanto à colocação de kits ou montagem das tubulações in loco.

Para a montagem destes ramais, os ambientes já deveriam estar taliscados, ou seja, a espessura do revestimento de argamassa já deveria ter sido definida de forma a fornecer uma referência ao operário executor dos ramais e sub-ramais quanto à profundidade em que os mesmos deveriam ser posicionados para evitar problemas posteriores com o acabamento dos registros.

De posse desta referência, o operário fixava um ou mais sarrafos de madeira junto à parede (parte inferior e superior do kit, por exemplo) de forma a posicionar inicialmente o kit a ser assente. Com auxílio de linhas, pregos e régua nível, o operário conferia o prumo e nível do kit a ser assente, assim como a sua posição relativa em relação à espessura do revestimento tendo-se como referência as taliscas. Ao posicioná-lo corretamente, o operário realizava seu chumbamento definitivo com argamassa de cimento produzida no próprio pavimento. Na Figura 5.13 pode-se observar as fases deste processo.

Estes mesmos cuidados eram tomados também na execução dos ramais e sub-ramais montados in loco. No entanto, dispensava-se o uso dos sarrafos uma vez que sua execução era feita por trechos. Ao término de cada trecho procedia-se sua fixação provisória com arame e ao final da execução de um conjunto de trechos realizava-se seu chumbamento. 


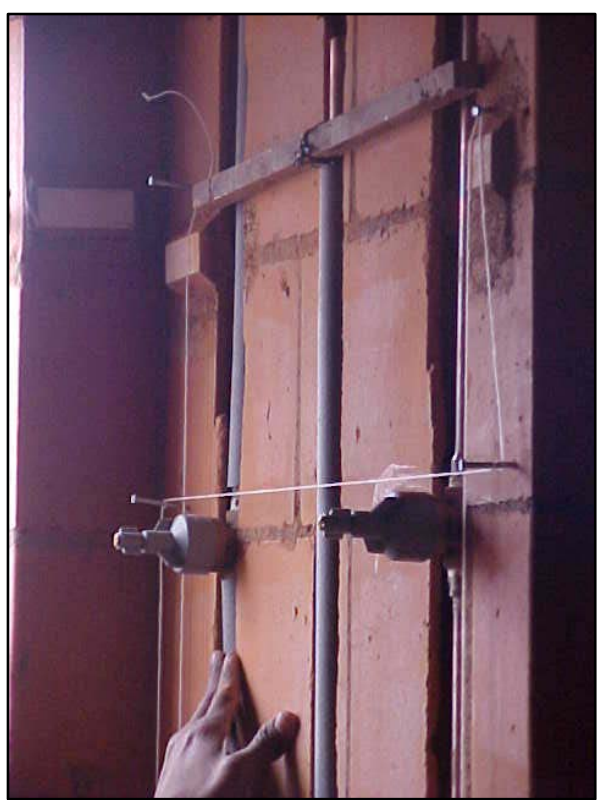

(a)

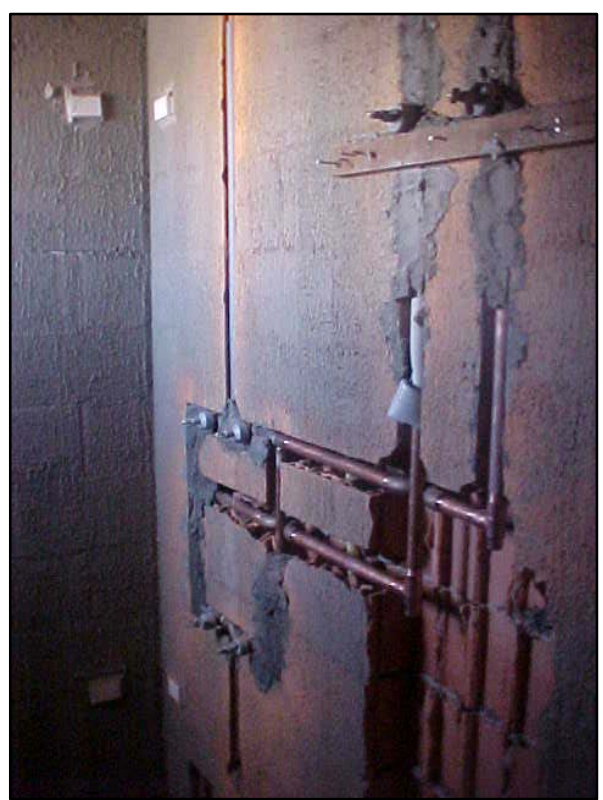

(b)

Figura 5.13 - Execução dos ramais e sub-ramais de água fria e água quente nos rasgos das paredes (kits) - SP0101; (a) nivelamento e aprumo do kit na parede (b) exemplo de um kit chumbado na parede

Os sub-ramais de alimentação de aparelhos sanitários juntos aos pilares eram posicionados rente aos mesmos enquanto que, os de alimentação de aparelhos sanitários juntos à parede de vedação eram embutidos na mesma. Os sub-ramais enquadrados na primeira situação eram totalmente recobertos posteriormente por argamassa. Mas, este serviço era de responsabilidade da equipe de revestimentos. $\mathrm{Na}$ Figura 5.14 pode-se observar estas duas situações. 


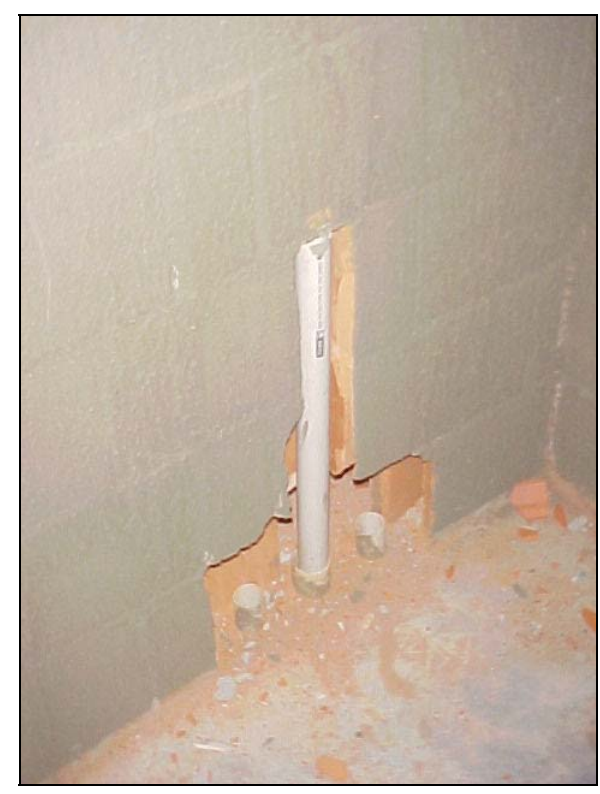

(a)

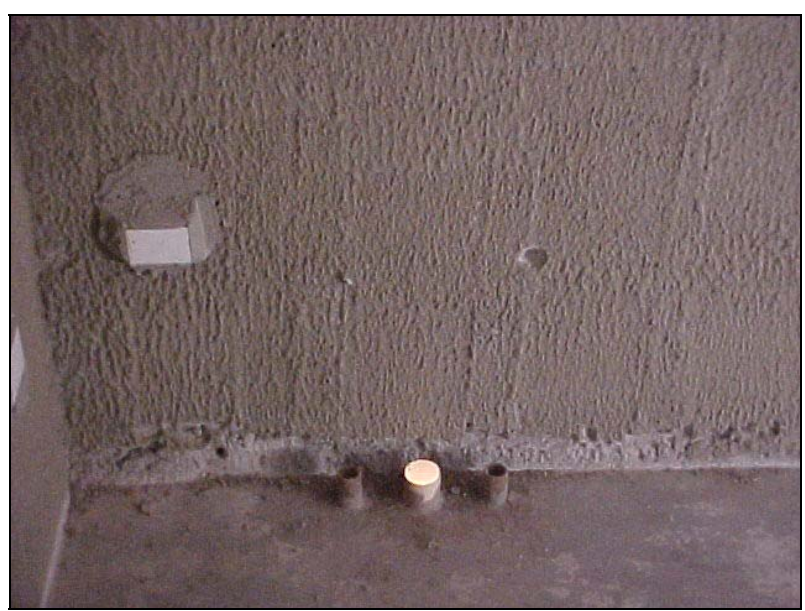

(b)

Figura 5.14 - Execução do ramal de esgoto - SP0101: (a) ramal de esgoto embutido na parede; (b) passante para execução do ramal de esgoto junto ao pilar

\section{Tubos de queda/colunas de ventilação esgoto/tubos de queda - águas pluviais}

Após a retirada do bloco de isopor da laje, inicialmente fazia-se a fixação de um perfil metálico junto à face interna da abertura do shaft de forma a se fazer a fixação das tubulações de PVC junto ao mesmo com auxílio de fita Walsywa. Este procedimento era realizado nos vários shafts do pavimento e para um conjunto de pavimentos. Após esta fixação, a equipe executora fazia a montagem das tubulações in loco e se encaminhava para o pavimento seguinte somente após a montagem das tubulações de todos os shafts de um pavimento. Imediatamente após a montagem das tubulações de um shaft as fixavam junto ao perfil metálico instalado. Na Figura 5.15 pode-se observar as fases deste processo. 


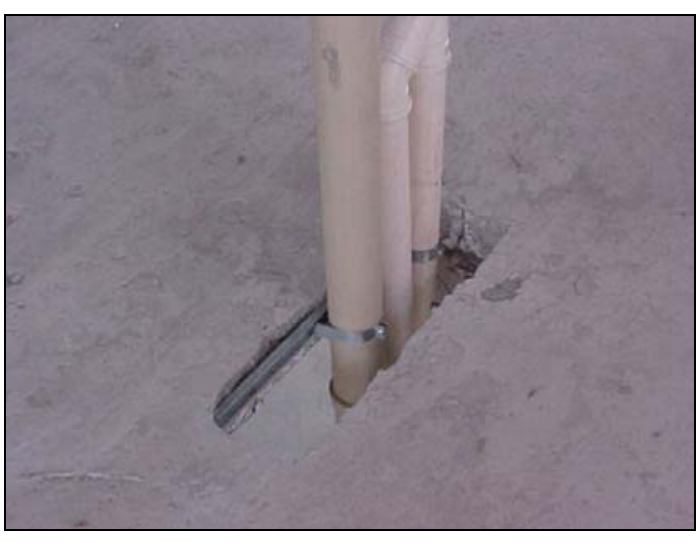

(a)

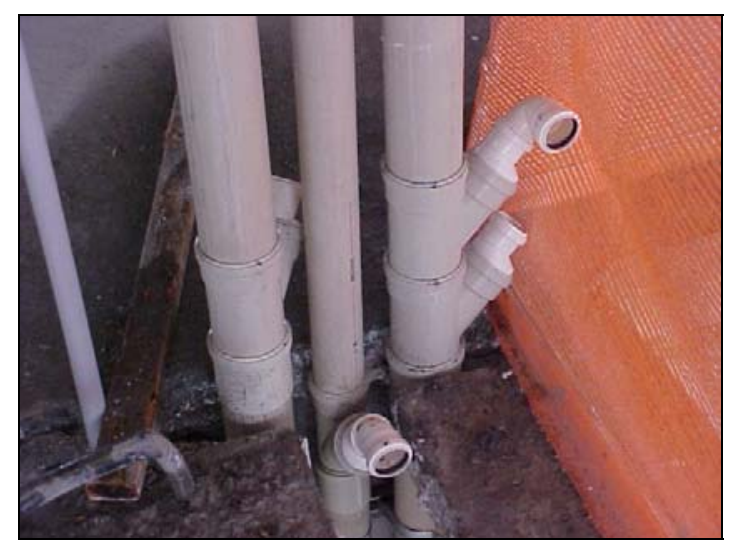

(b)

Figura 5.15 - Execução dos tubos de queda (esgoto, águas pluviais) e colunas de ventilação - SP0101: (a) tubos de queda fixados junto ao perfil metálico (b) vista das tubulações de esgoto do shaft da área de serviço

\section{Ramais de esgoto/águas pluviais - tetos; ramais de esgoto paredes}

Após a montagem das tubulações verticais nos shafts, a equipe executora se encarregava da execução dos ramais de esgoto e de descarga dos ambientes molháveis. A execução destes ramais sob a laje iniciava-se com a fixação dos pinos na laje para sustentação das tubulações com auxílio de um revólver. Estes pinos eram fixados lateralmente aos passantes da bacia sanitária e caixa sifonada e em posições intermediárias de trechos de tubulações de maior comprimento. Simultaneamente à montagem dos trechos de tubulações destes ramais os operários as fixavam junto ao pino por meio de fita Walsywa. Na Figura 5.16 pode-se observar as fases deste processo. 


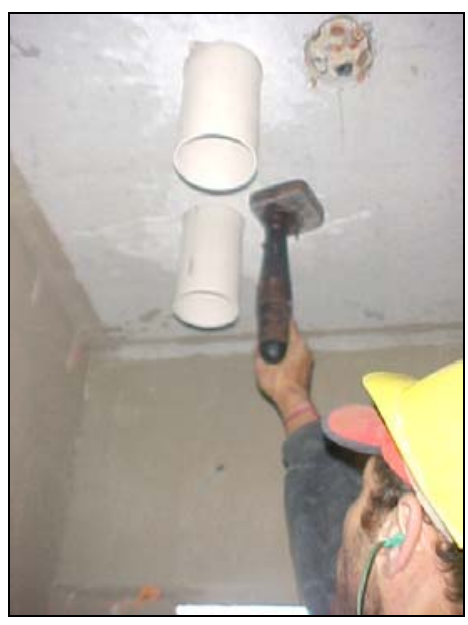

(a)

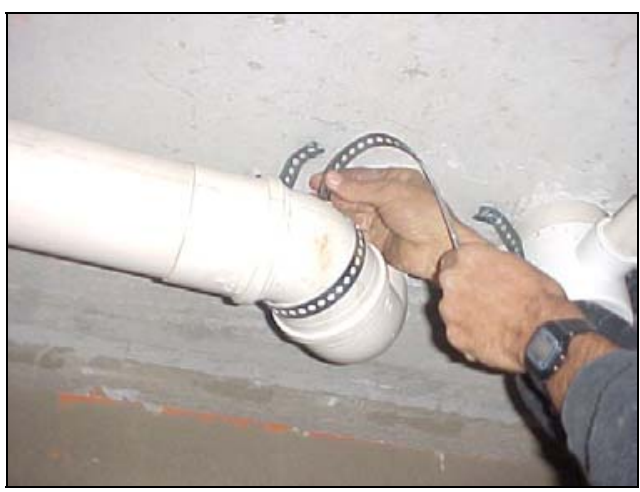

(c)

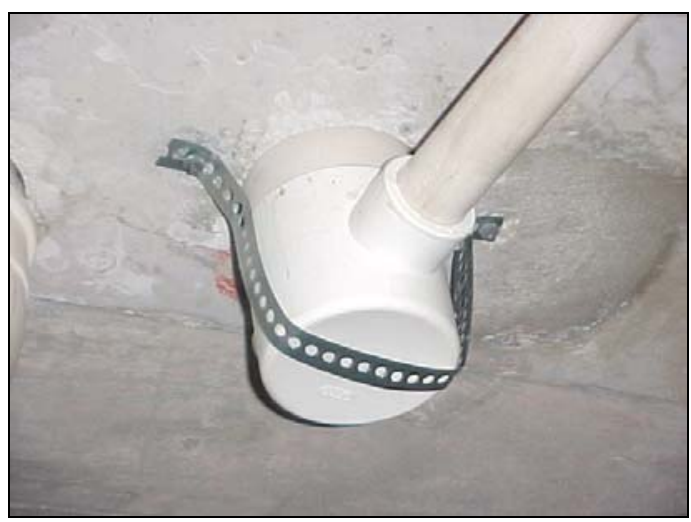

(b)

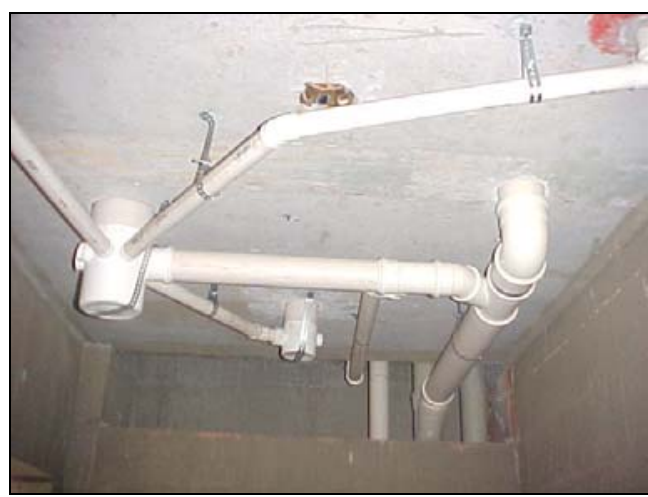

(d)

Figura 5.16 - Execução dos ramais de esgoto - SP0101: (a) fixação do pino junto à laje; (b) fita Walsywa já colocada sobre o ralo sifonado; (c) colocação da fita Walsywa junto à tubulação de esgoto; (d) vista geral dos ramais de esgoto já devidamente fixados

Com relação aos ramais verticais, estes foram executados segundo o mesmo princípio dos sub-ramais de água fria e água quente. 


\subsubsection{SP0201}

\section{Fixação da tubulação nas paredes}

Ao contrário do procedimento de execução utilizado na obra SP0101, nesta obra o chumbamento das tubulações nos rasgos das paredes foi realizado em momento distinto a sua montagem. A argamassa de cimento e areia era produzida no próprio pavimento, sobre uma carriola, e o operário percorria os ambientes molháveis do pavimento chumbando as tubulações. Esta atividade consistia em verificar o nível, prumo, profundidade das tubulações nos rasgos e lançar a argamassa em determinados pontos dos trechos de tubulações. As tubulações seriam cobertas posteriormente pelo revestimento de argamassa. Na Figura 5.17 pode-se observar as fases deste processo.

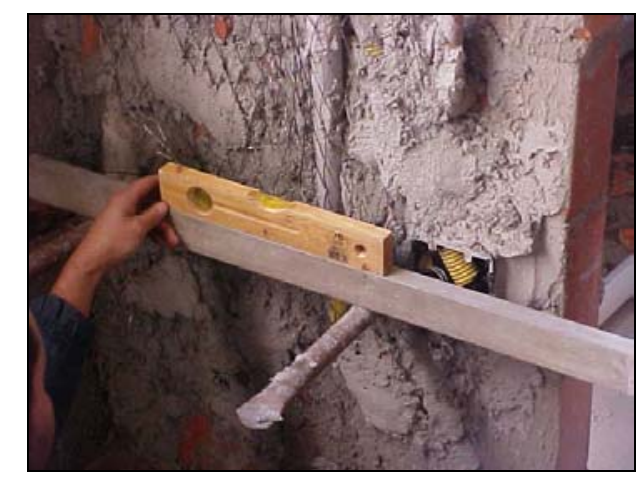

(a)

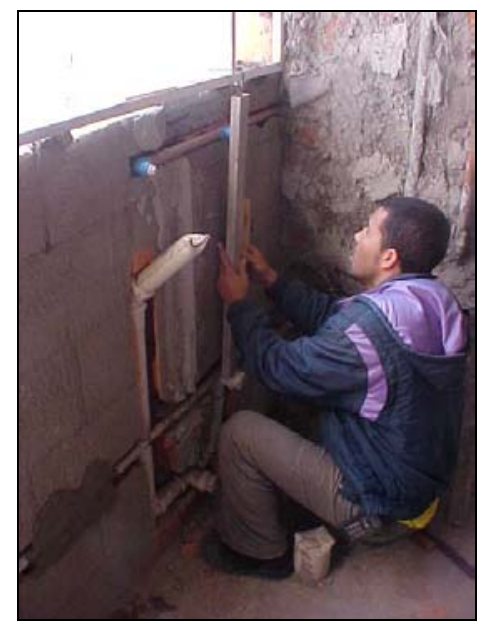

(b)

Figura 5.17 - Chumbamento das tubulações nas paredes - SP0201: (a) verificação do nível do trecho de tubulação (b) verificação do prumo do trecho de tubulação 


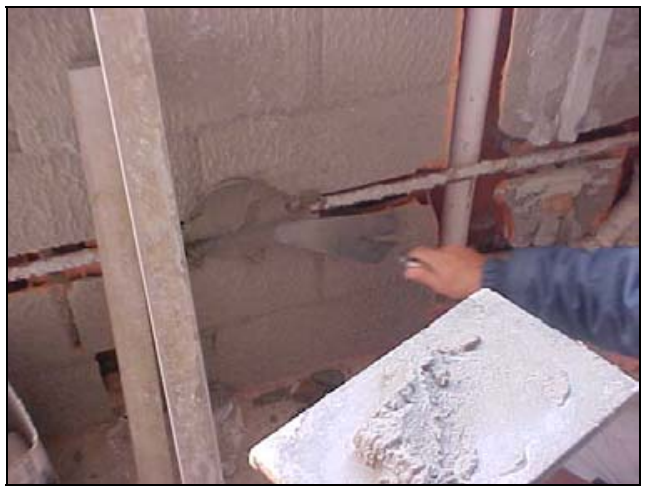

(c)

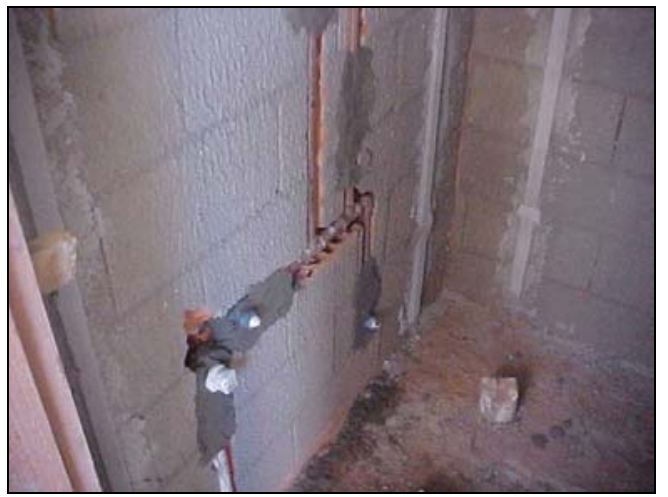

(d)

Figura 5.17 - Chumbamento das tubulações nas paredes - SP0201: (c) chumbamento da tubulação com argamassa de cimento; (d) tubulações chumbadas nas paredes (continuação)

\section{Produção de Kits}

Foi aplicado o mesmo raciocínio quanto às partes dos trechos dos ramais e subramais de água fria, água quente e gás a serem produzidas em uma central. A diferença, neste caso, para as demais obras que se verificou esta postura, reside no fato de se produzir também kits de tubulações de PVC, além dos compostos por tubulações de cobre.

A central de produção se localizava na própria sala reservada à subempreiteira responsável pela execução dos sistemas prediais. Inclusive, os componentes também estavam estocados nesta sala. Em relação à obra SP0101, as condições de produção destes kits eram mais precárias, inexistindo uma bancada específica para tal. $\mathrm{Na}$ Figura 5.18 pode-se observar as fases deste processo. 


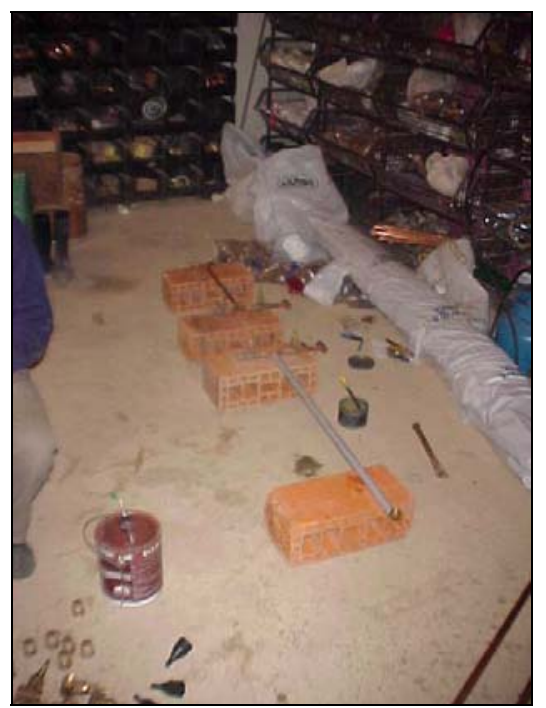

(a)

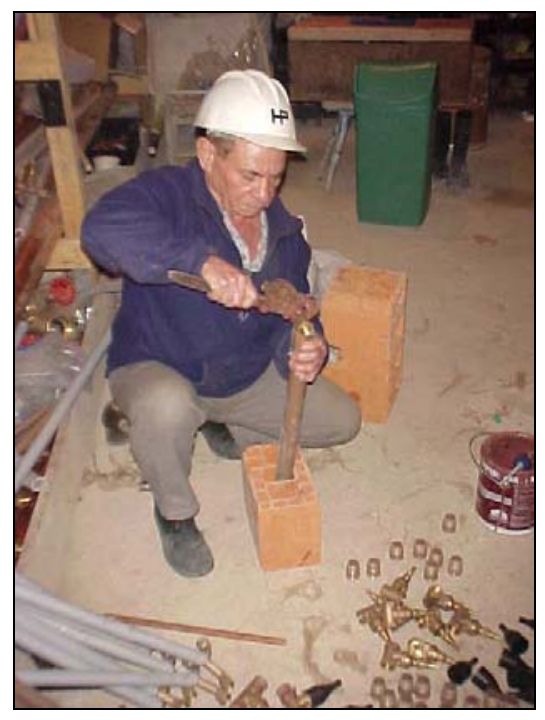

(b)

Figura 5.18 - Produção de kits - SP0201: (a) e (b) bancada improvisada

\section{Ramais de distribuição: água fria (PVC) e água quente (Cobre)}

Os ramais de distribuição de água fria (em PVC) e de água quente (em cobre) foram executados seguindo-se os mesmos procedimentos técnicos adotados na obra SP0101, no entanto, diferindo quanto à estratégia de execução. Enquanto que na obra SP0101 fazia-se inicialmente a fixação dos pinos na laje em toda a extensão do trajeto das tubulações para sua posterior montagem e fixação com fita Walsywa nesta obra, esta operação era feita trecho a trecho, ou seja, para cada trecho a equipe executora fincava o pino na superfície inferior da laje com auxílio de um revólver a pólvora, montava a tubulação e a fixava com braçadeiras metálicas junto ao pino.

Também, como particularidade desta obra, destaca-se o fato de que, em alguns trechos, estes ramais de distribuição estar posicionados sobre a última fiada de alvenaria, sendo embutidos posteriormente na camada de fixação entre a alvenaria e a laje. Na Figura 5.19 pode-se observar as fases deste processo. 


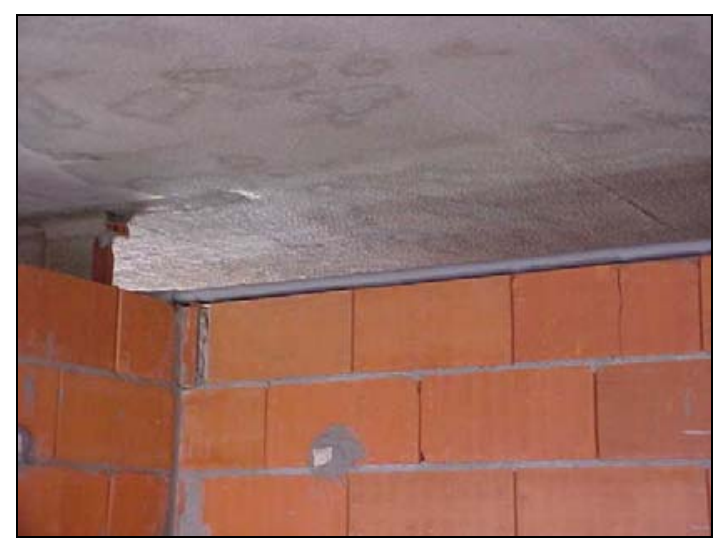

(a)

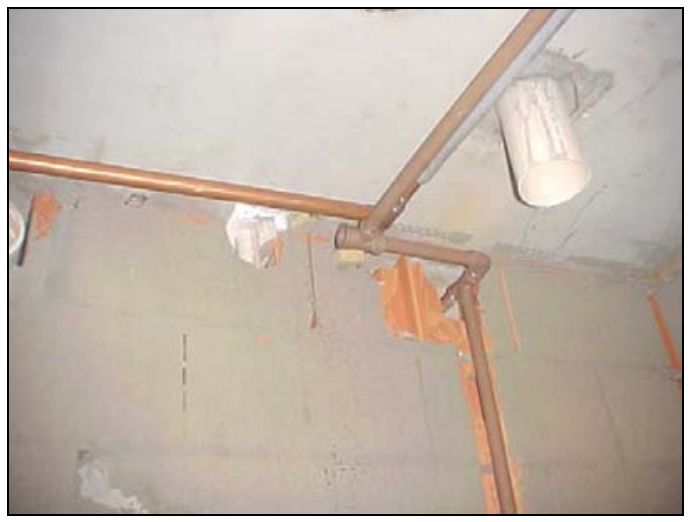

(c)

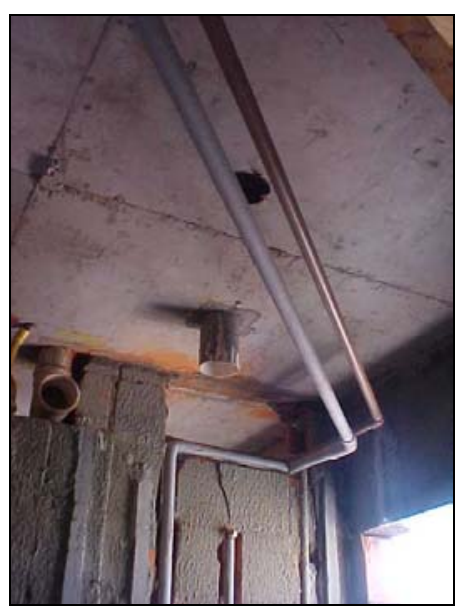

(b)

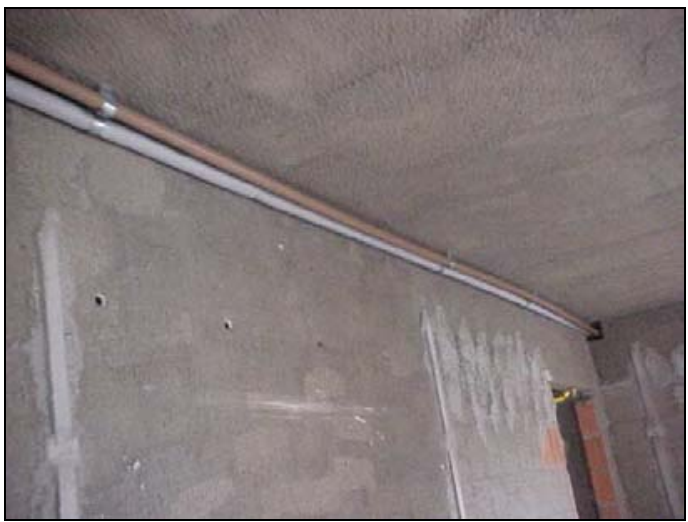

(d)

Figura 5.19 - Ramais de distribuição de água fria - SP0201: (a) sobre a última fiada de alvenaria; (b) e (c) sob a laje de teto; (d) sob a laje de teto, porém fixadas com braçadeiras

Ramais e sub-ramais: gás, água quente (cobre) e água fria (PVC)

Os ramais e sub-ramais de água fria e água quente embutidos nas paredes foram divididos, em sua maioria, em kits. Portanto, sua execução consistia em alojá-los corretamente (considerando prumo, nível e profundidade) nos rasgos previamente executados. Eventualmente, a interligação entre diferentes kits em um mesmo ambiente era feito in loco pela própria equipe encarregada da colocação dos kits. 
Eram posicionados nos rasgos e fixados provisoriamente com arame e os acertos de profundidade da tubulação em relação às taliscas do revestimento de argamassa eram feitos aprofundando-se os rasgos nas paredes ou acrescentando-se cacos de blocos atrás da tubulação de forma a diminuir a profundidade do rasgo em determinados casos. A fixação definitiva destes ramais, ou seja, seu chumbamento com argamassa de cimento, conforme já ressaltado anteriormente, era feita posteriormente por uma equipe específica. Na Figura 5.20 pode-se observar as fases deste processo.

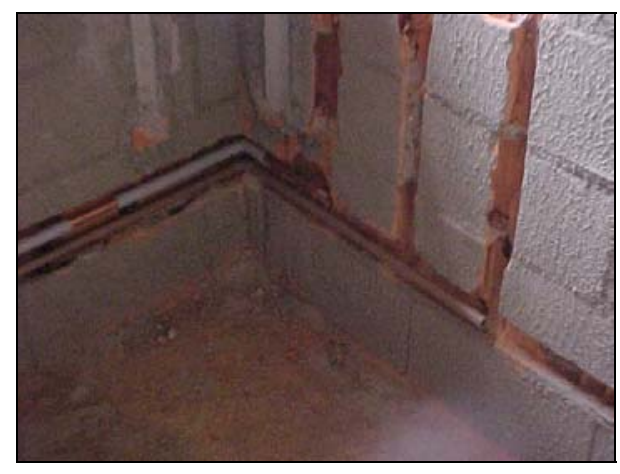

(a)

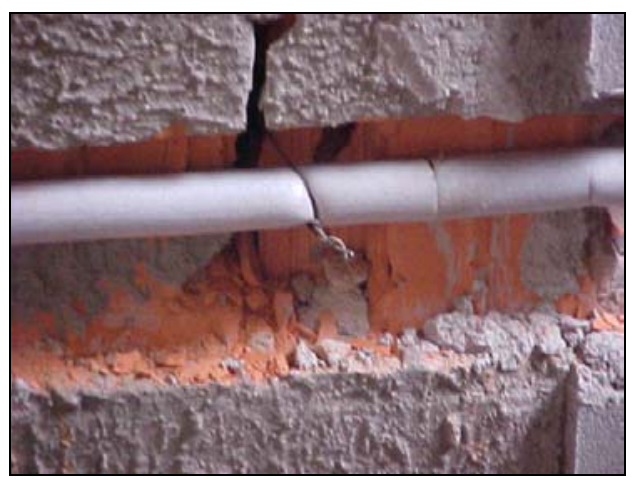

(c)

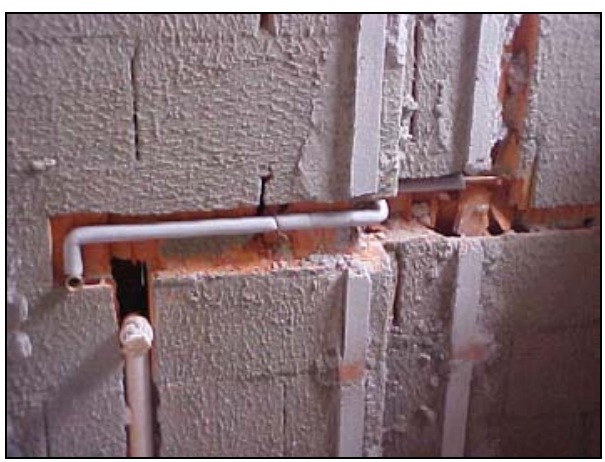

(b)

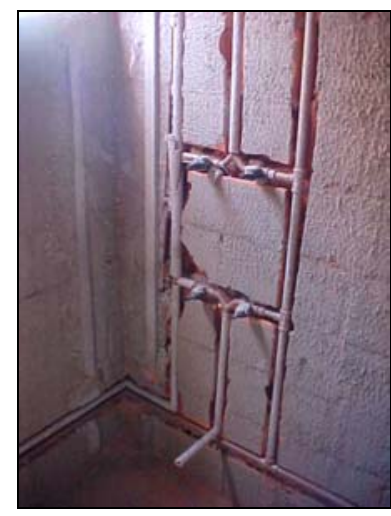

(d)

Figura 5.20 - Ramais e sub-ramais de água fria e água quente - SP0201: (a) e (b) ramais e sub-ramais fixados provisoriamente nos rasgos das paredes; (c) detalhe da fixação provisória da tubulação de água quente; (d) kit de ramal e sub-ramal de água quente e água quente fixado provisoriamente nos rasgos da parede 


\section{Ramais de esgoto/águas pluviais - tetos; ramais de esgoto paredes}

A execução dos ramais de esgoto e descarga iniciou-se, em cada pavimento, após a execução dos tubos de queda e colunas de ventilação nos shafts. A equipe executora iniciava a execução pela tubulação de maior diâmetro, ou seja, pelo ramal de esgoto, ligando o tubo passante da bacia sanitária ao tubo de queda. Os outros trechos eram executados em seguida, completando assim o esgoto sob a laje teto de um ambiente molhável. Em relação à obra SP0101, destaca-se o fato de não se realizar a fixação das tubulações ao longo dos trechos de tubulações e nem junto às conexões aos tubos passantes. Na Figura 5.21 são ilustrados os ramais de descarga e esgoto executados nesta obra.

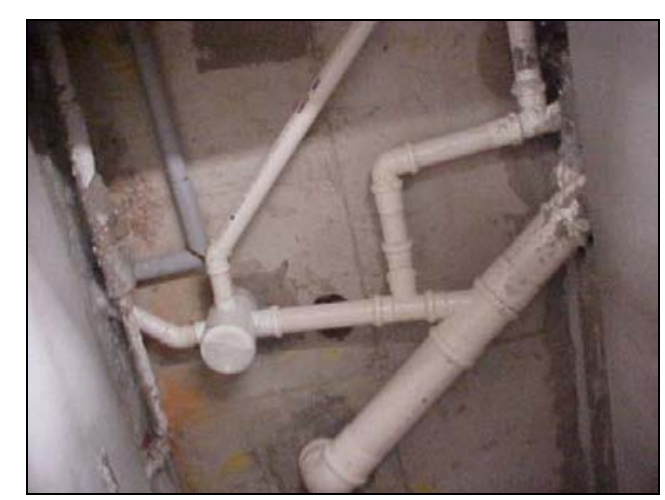

(a)

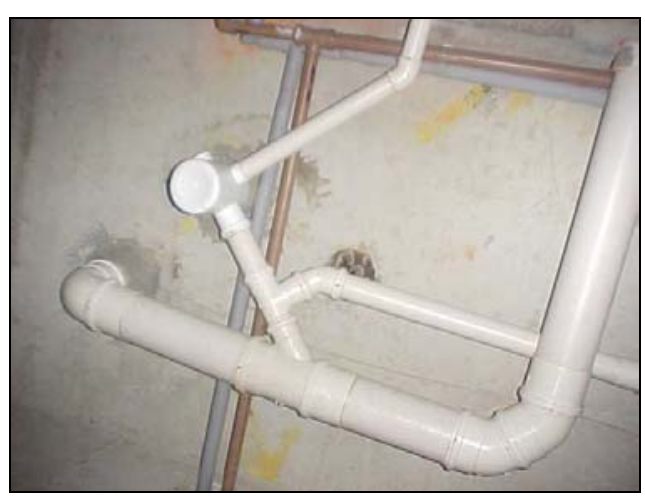

(b)

Figura 5.21 - Ramais de esgoto sob a laje de teto - SP0201: (a) e (b) ramais de esgoto dos banheiros das suítes

Já os ramais de esgoto embutidos nas paredes foram executados seguindo-se os mesmos procedimentos adotados para os ramais e sub-ramais de água fria e água quente. Na Figura 5.22 pode-se observar os ramais executados na cozinha e em um dos banheiros das suítes. 


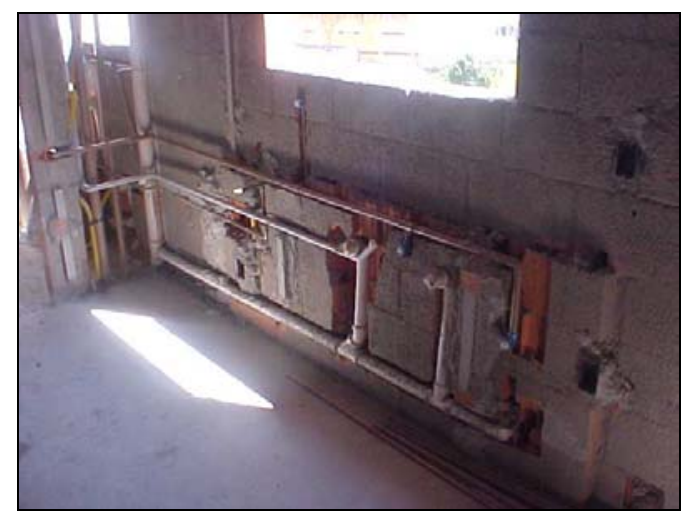

(a)

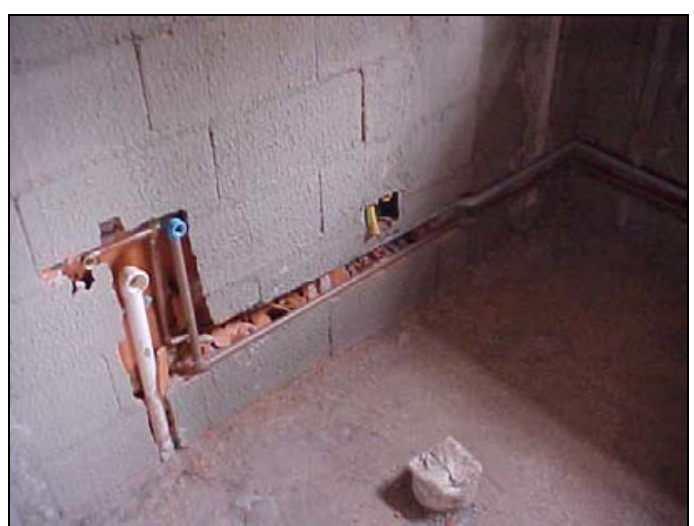

(b)

Figura 5.22 - Ramais de esgoto embutidos nas paredes - SP0201: (a) cozinha; (b) banheiro de suíte

\subsubsection{SP0301}

\section{Corte e rasgo de paredes}

O corte e rasgo das paredes foram executados da mesma forma do que nas outras obras, diferindo apenas no fato de as paredes serem de blocos de concreto enquanto nas demais as paredes eram de blocos cerâmicos.

\section{Produção de kits}

Foi providenciada uma bancada para a produção de kits dos ramais e sub-ramais de água fria e água quente nas proximidades da sala da subempreiteira responsável pela execução dos sistemas prediais. As partes a serem produzidas também se resumem àquelas em que têm em sua configuração conexões roscáveis. Na Figura 5.23 ilustrase a bancada utilizada pelos operários na execução dos kits assim como o detalhe do esboço feito pelo encarregado dos kits a serem produzidos. 


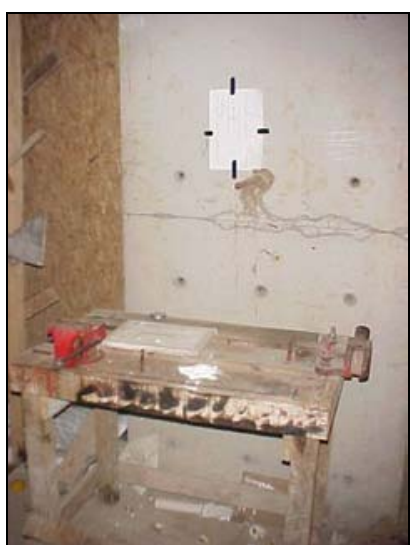

(a)

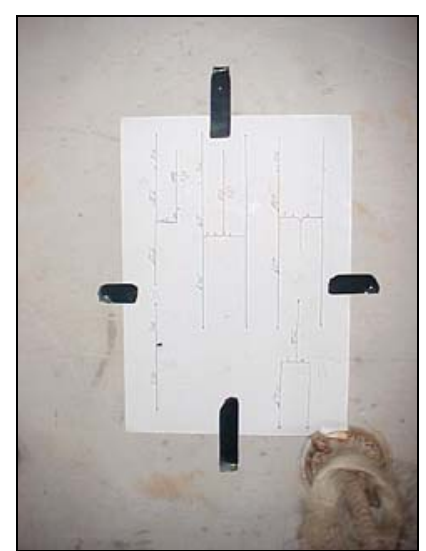

(b)

Figura 5.23 - Produção de kits - SP0301: (a) bancada localizada no $1^{\circ}$ subsolo; (b) esboço dos kits a serem produzidos

\section{Prumadas de água fria, água quente, gás e incêndio}

Foi acompanhada a execução das prumadas dos últimos pavimentos do edifício. Durante os dias de coleta, observou-se apenas a montagem das tubulações dos últimos pavimentos do edifício, não se observando, portanto, sua fixação e chumbamento. As tubulações, assim como as conexões eram transportadas para o pavimento. Os acessórios, tais como o botijão de gás, se encontravam no próprio pavimento. Observou-se que, em alguns casos, as prumadas de cobre foram executadas em shafts nos quais as tubulações de PVC já estavam presentes. Na Figura 5.24 pode-se observar fases do procedimento de execução das prumadas nesta obra. 


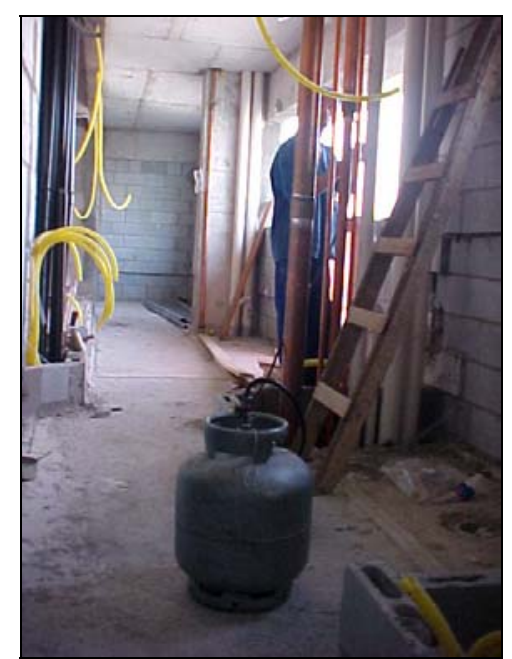

(a)

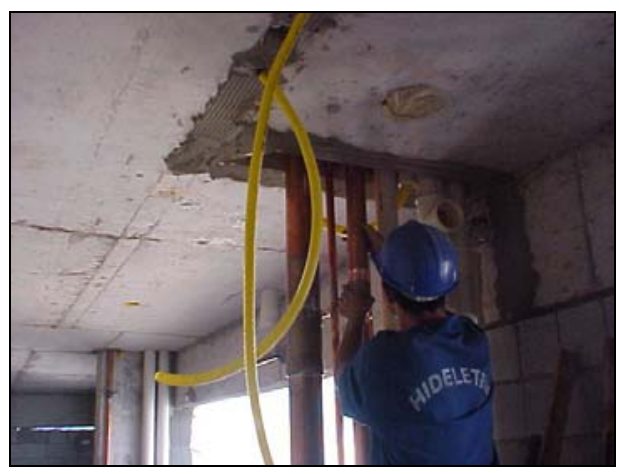

(b)

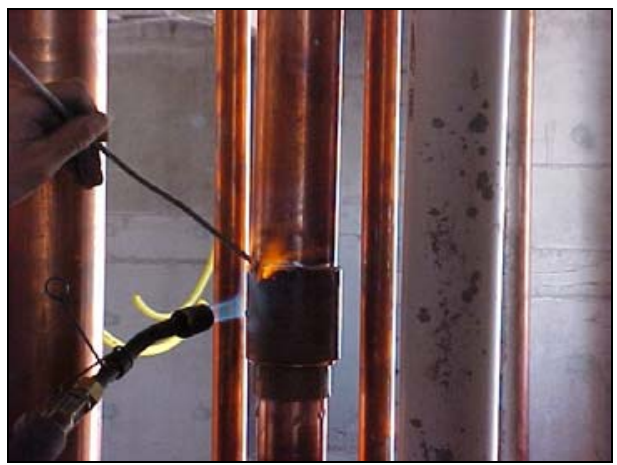

(c)

Figura 5.24 - Execução das prumadas - SP0301: (a) operário lixando o topo da tubulação; (b) operário colocando o tubo na conexão; (c) operário realizando a solda entre a conexão e o tubo

Ramais de distribuição: água fria e água quente

A equipe encarregada da execução destes ramais inicialmente fazia a locação e fixação dos pinos dos suportes destas tubulações ao longo do seu trajeto em todo o apartamento. Enquanto que nas obras anteriores esta fixação das tubulações sob a laje de teto foi executada com uso de fita Walsywa, nesta adotou-se um suporte metálico aparafusado com bucha na laje. Este suporte é dotado de um perfil sob o 
qual caminham as duas tubulações: a de água fria e a de água quente. Após a montagem, colocava-se o isolante térmico na tubulação de água quente. Não se verificou a preocupação com relação à possibilidade de ocorrência de corrosão galvânica entre o tubo de cobre do ramal de distribuição de água fria e o suporte, uma vez que não se colocou nenhum componente isolante entre os mesmos. Na Figura 5.25 pode-se observar as fases deste processo.

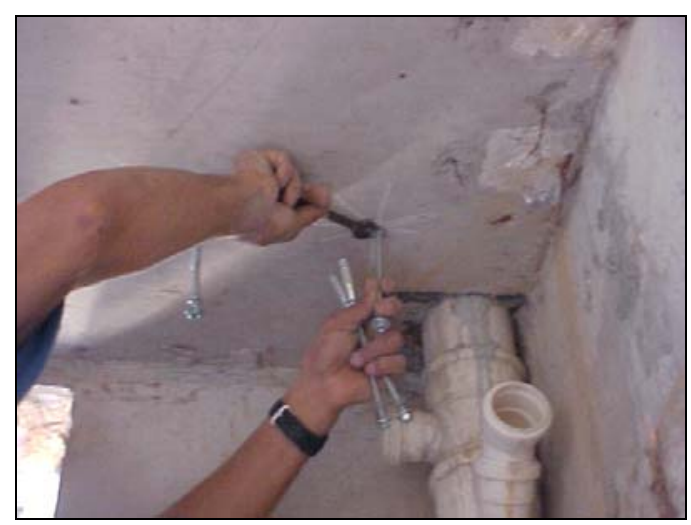

(a)

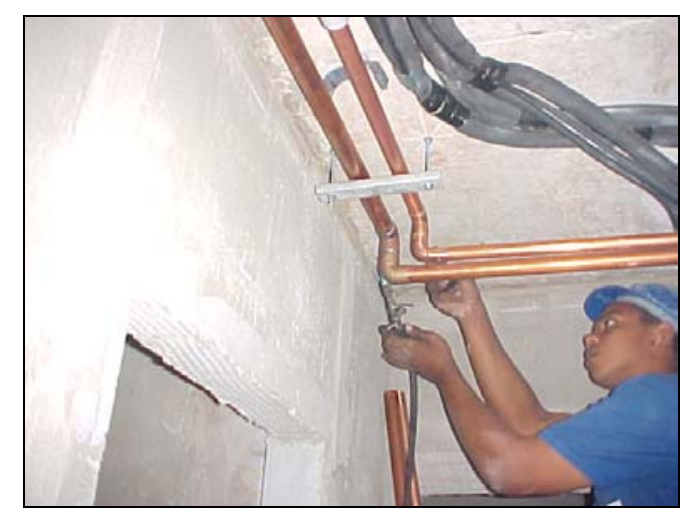

(b)

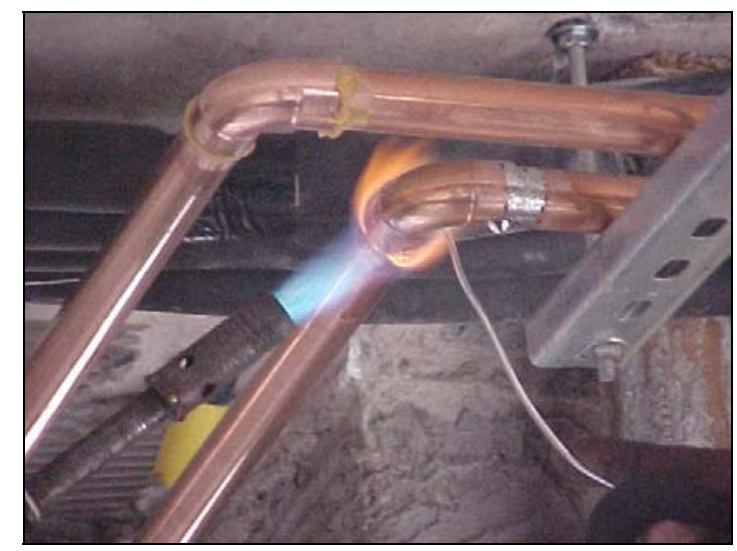

(c)

Figura 5.25 - Ramais de distribuição de água fria e água quente - SP0301: (a) fixação do piso com rosca para montagem do suporte das tubulações; (b) montagem do ramal de distribuição água fria e água quente, (c) detalhe da solda da tubulação com a conexão, com destaque para o suporte utilizado nesta obra 


\section{Ramais e sub-ramais: gás, água quente e água fria}

Em se tratando dos ramais e sub-ramais de água fria e água quente identifica-se duas situações distintas: ambientes com ramais e sub-ramais embutidos na parede e sob a laje de piso do apartamento (banheiros e lavabos) e ramais e sub-ramais embutidos nas paredes (cozinha e área de serviço).

No que diz respeito à última situação, o processo de execução se assemelha às obras SP0101 e SP0201, ou seja, uma equipe se encarregava de fazer a locação, corte e rasgo da alvenaria e outra equipe, em outro momento, fazia a montagem das tubulações e respectiva fixação (chumbamento).

Os sub-ramais de água fria e água quente dos outros ambientes (primeira situação) diferem dos anteriormente descritos por ser configurarem em apenas uma tubulação vertical embutida no rasgo da alvenaria, atravessando a laje de piso do ambiente e conectando-se aos ramais localizados sob a laje de piso. Nestes locais, antes da concretagem foram fixados blocos de isopor para sua posterior retirada e chumbamento desta tubulação.

Após a execução dos ramais responsáveis pela condução da água fria e água quente do ramal de distribuição aos ramais e sub-ramais que alimentam os pontos de consumo do ambiente e da execução dos sub-ramais embutidos nas paredes, conforme descrito no parágrafo anterior, a equipe de execução reunia as condições necessárias para a execução dos ramais e sub-ramais localizados sob a laje de piso deste ambiente, completando, assim, a execução dos ramais em cada ambiente.

Finalmente, destaca-se que os ramais de água fria e água quente que interligam, respectivamente, os ramais de distribuição de água fria e água quente, foram produzidos em uma central de produção de kits. Portanto, sua execução consiste apenas em chumbá-los no nível e prumos corretos nos rasgos previamente feitos nas 
paredes. Na Figura 5.26 pode-se observar o kit de ramais de água fria e água quente instalado na parede e os sub-ramais (pontos de alimentação do lavatório) de um dos banheiros das suítes.

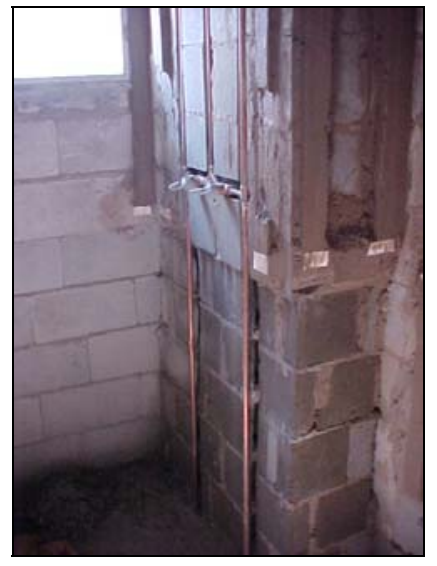

(a)

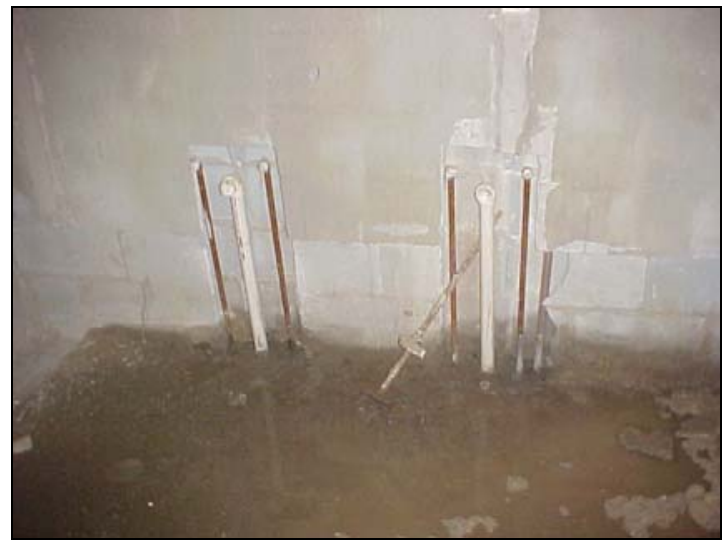

(b)

Figura 5.26 - Ramais de água fria e água quente - SP0301: (a) ramais destinados à condução de água fria (direita) e água quente (esquerda) do ramal de distribuição aos ramais e sub-ramais que alimentam os pontos de consumo do ambiente; (b) sub-ramais de água fria e água quente de um dos banheiros das suítes

Tubos de queda/colunas de ventilação esgoto/tubos de queda - águas pluviais

A montagem dos tubos de queda nesta obra seguiu o mesmo procedimento da obra SP0101. No entanto, durante o período de coleta observou-se apenas a montagem destas tubulações, não se tendo a oportunidade de acompanhar sua fixação e chumbamento nos shafts.

\section{Ramais de esgoto/águas pluviais - tetos; ramais de esgoto paredes}

Da mesma forma que para os tubos de queda e colunas de ventilação, os ramais de esgoto e águas pluviais localizados sob a laje de teto e os ramais de esgoto embutidos nas paredes foram executados seguindo-se os mesmos procedimentos adotados na 
obra SP0101 e SP0201, tendo-se como semelhança com esta última o fato de não se fazer também a fixação ao longo das tubulações de maior comprimento e na região dos passantes junto à laje.

Os ramais de esgoto embutidos nas paredes dos banheiros, que se resumem ao ramal dos lavatórios, foram executados juntamente com os sub-ramais de água fria e água quente, conforme ilustrado na Figura 5.26 anteriormente apresentada.

\subsubsection{SP0401}

\section{Abertura de laje e colocação de passantes}

Nesta obra teve-se a oportunidade de se acompanhar a abertura das lajes e colocação dos passantes de ralos e de bacias sanitárias. Após a sua locação, tendo-se como referência o revestimento já executado, a equipe executora fazia a abertura destes pontos já providos de blocos de vermiculita posicionados antes da concretagem das lajes com auxílio de furadeira ou talhadeira. Após a abertura, colocava-se um anteparo de madeira compensada na face inferior da laje amarrado com arame em duas barras de aço posicionadas na parte superior da mesma. Em seguida posicionava-se o tubo passante, previamente pintado com betume e com areia grossa aderida junto ao

mesmo. Ao final deste processo, procedia-se o seu chumbamento utilizando argamassa de cimento. Na Figura 5.27 pode-se observar as fases deste processo. 


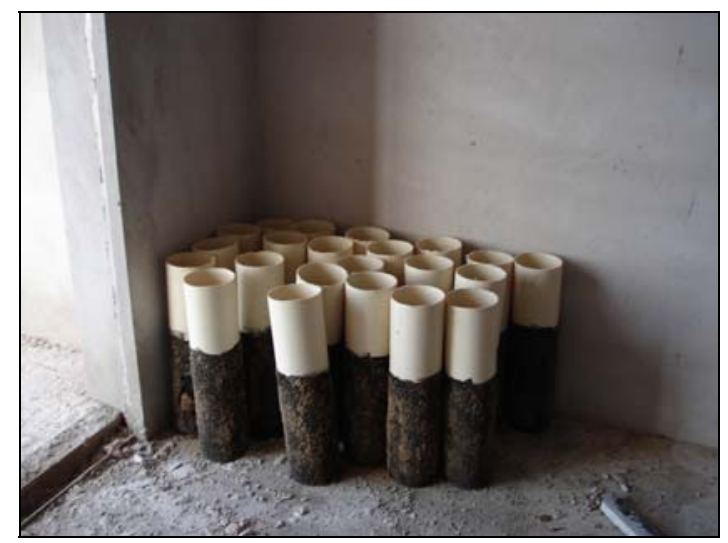

(a)

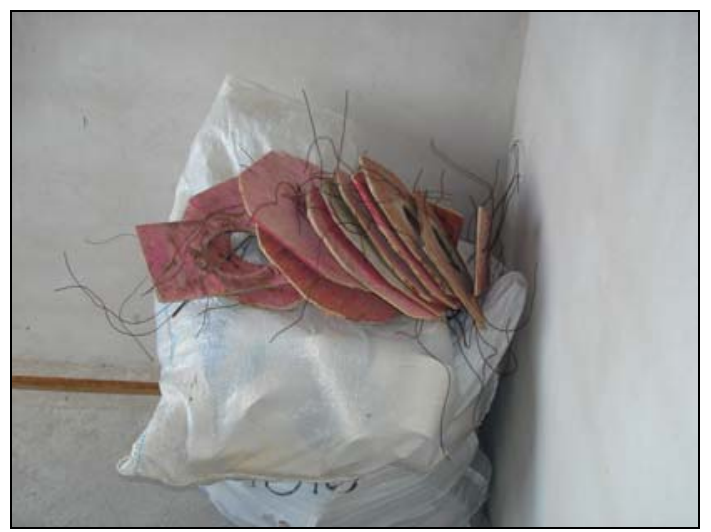

(c)

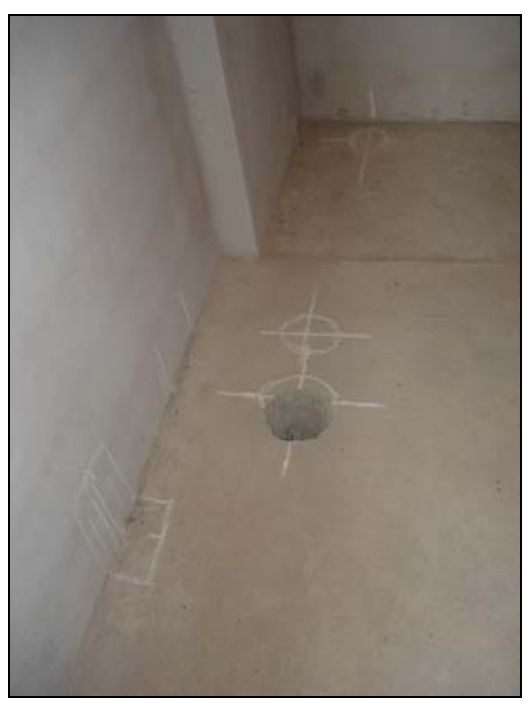

(b)

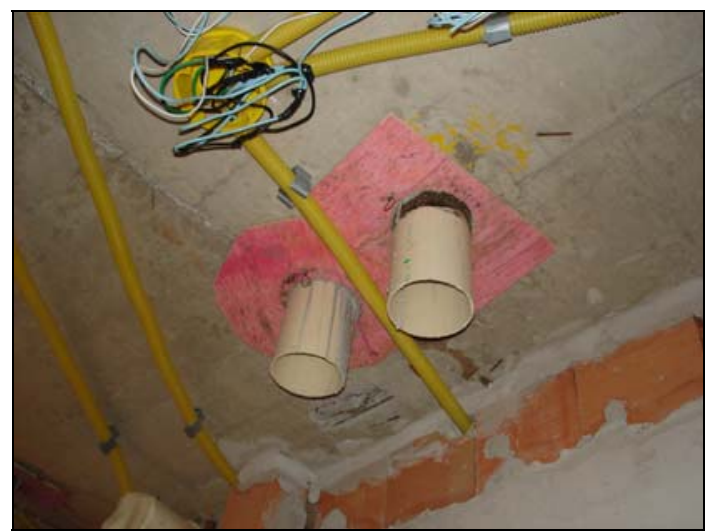

(d)

Figura 5.27 - Abertura da laje e chumbamento dos passantes - SP0401: (a) estoque de tubos passantes; (b) locação e abertura de furo na laje; (c) estoque de anteparo de madeira compensada resinada; (d) tubos passantes chumbados

\section{Ramal de distribuição de água fria (PVC)}

A execução dos ramais de distribuição de água fria ocorreu seguindo-se os mesmos procedimentos adotados na obra SP0201. Como diferença destaca-se apenas o fato de que nesta obra, estes ramais foram fixados por arames junto à laje (Figura 5.28), ao contrário da obra SP0201, onde se utilizava fita Walsywa. 


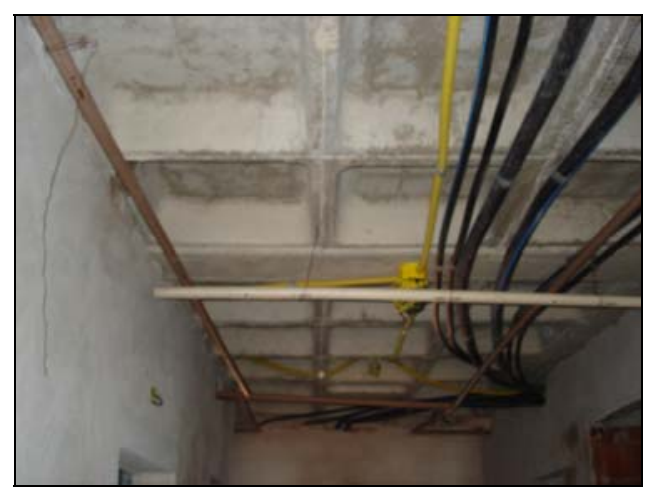

(a)

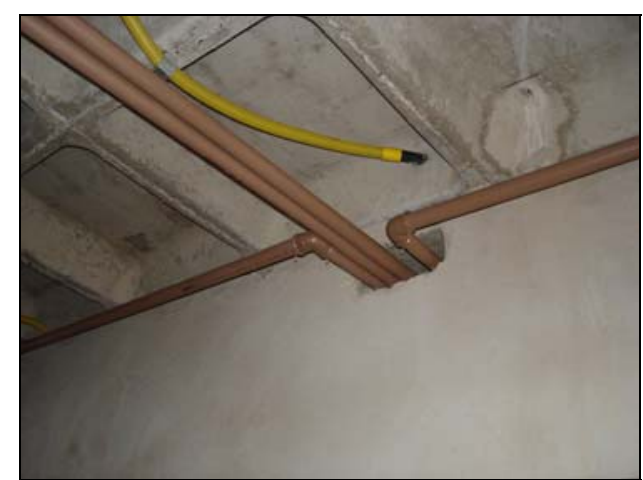

(b)

Figura 5.28 - Execução dos ramais de distribuição de água fria: (a) ramal fixado por arame junto à laje; (b) ramal sem fixação junto à laje

\section{Montagem dos ramais e sub-ramais de água fria e esgoto junto às paredes}

Esta obra tem como particularidade no que diz respeito aos sub-ramais de água fria e ramais de esgoto dos banheiros, o fato de os mesmos ficarem embutidos em uma carenagem junto à parede, não havendo, portanto, a necessidade de se rasgá-las para o seu embutimento. Para sua execução, a equipe executora inicialmente faz a abertura dos pontos providos de blocos de vermiculita previamente locados antes da concretagem das lajes. Esta abertura é feita com auxílio de uma furadeira. Após a sua abertura, fixam-se sarrafos de madeira junto à parede e neles são fixados provisoriamente os sub-ramais de água fria e ramal de esgoto. Após o acerto do prumo e altura correta, procede-se o chumbamento destas tubulações. Para este chumbamento, prende-se um anteparo de madeira compensada na parte inferior da laje com auxílio de arames amarrados em duas barras de aço posicionadas na parte superior da laje. Em seguida, faz-se o chumbamento destas tubulações com argamassa de cimento produzida no próprio pavimento. Na Figura 5.29 pode-se observar fases deste processo. 


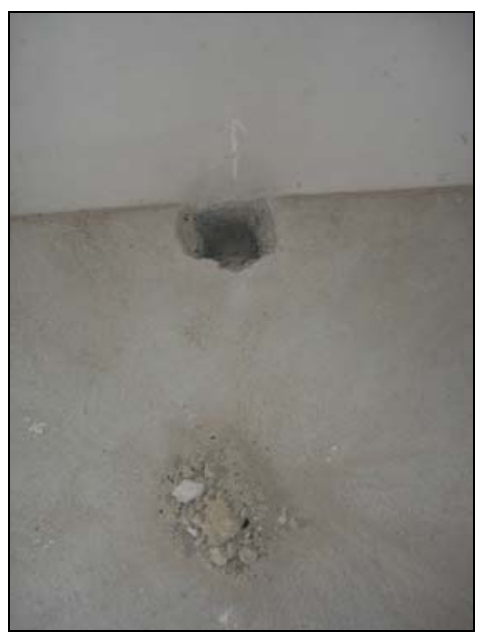

(a)

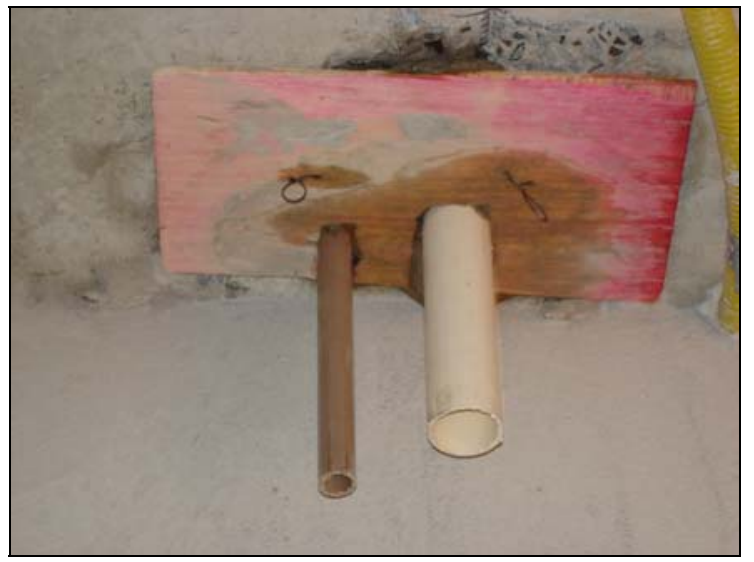

(c)

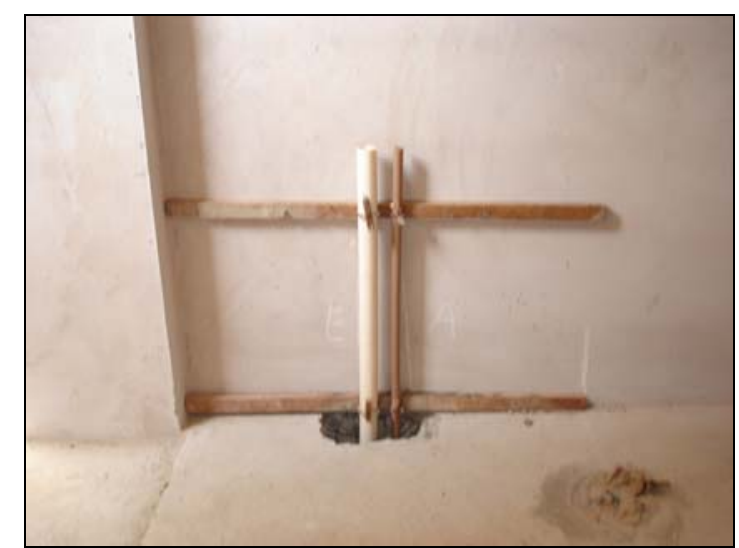

(b)

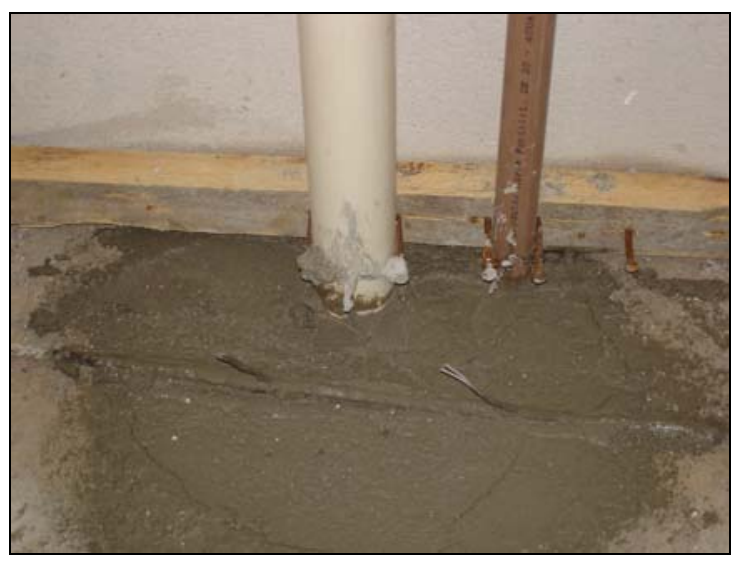

(d)

Figura 5.29 - Sub-ramal de água fria e ramal de esgoto - SP0401: (a) furo na laje para colocação das tubulações; (b) tubulações fixadas junto aos sarrafos presos à parede; (c) anteparo de madeira compensada para o chumbamento das tubulações; (d) tubulações chumbadas com argamassa de cimento (detalhe: barras de aço utilizada para sustentação do anteparo)

Tubos de queda/colunas de ventilação esgoto/tubos de queda - águas pluviais

Para esta obra, a execução dos tubos de queda de esgoto, colunas de ventilação e tubos de queda de águas pluviais consistiu na montagem in loco das respectivas tubulações nos shafts distribuídos pelo pavimento-tipo. Nos locais previstos para os 
shafts foram posicionados blocos de vermiculita antes da concretagem das lajes. Antes da montagem das tubulações, a equipe executora fazia a abertura em pontos nos quais as tubulações iriam ser montadas. Estas, durante a montagem, eram fixadas provisoriamente com arame junto às paredes. Em seguida, a equipe executora realizava o chumbamento das tubulações junto aos shafts. Esta atividade não foi acompanhada nesta obra. Na Figura 5.30 pode-se observar fases deste processo.

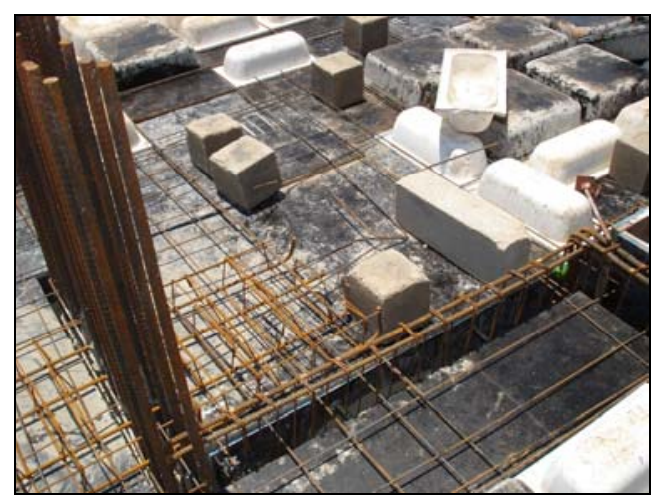

(a)

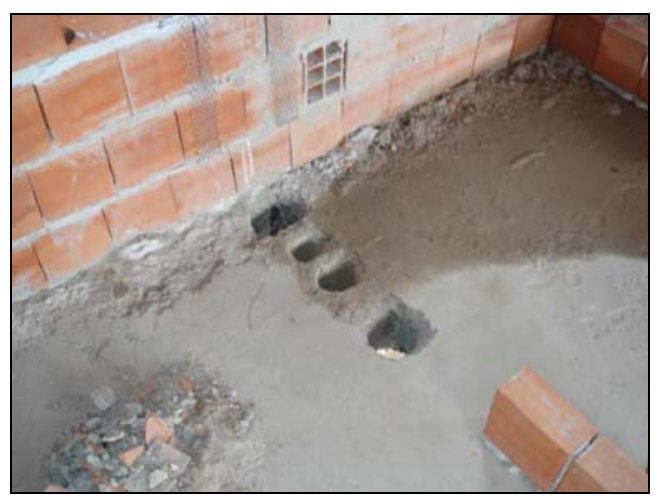

(b)

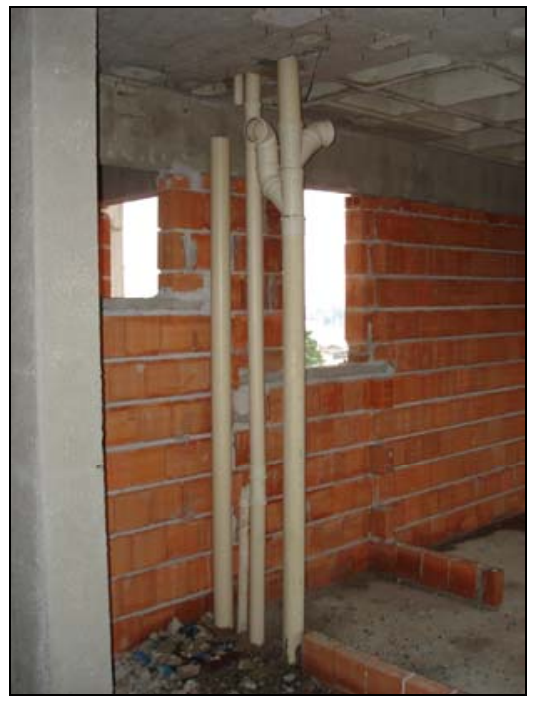

(c)

Figura 5.30 - Execução dos tubos de queda de esgoto, colunas de ventilação e tubos de queda de águas pluviais - SP0401: (a) Posicionamento dos blocos de vermiculita na posição dos shafts antes da concretagem da laje; (b) abertura de furos para passagem das tubulações; (c) tubulações montadas no shaft 


\section{Ramais de esgoto/águas pluviais - tetos; ramais de esgoto paredes}

Para a execução destes ramais foram seguidos os mesmos procedimentos descritos para a obra SP0101. Na Figura 5.31 são ilustrados os ramais de esgoto sob o teto já executados.

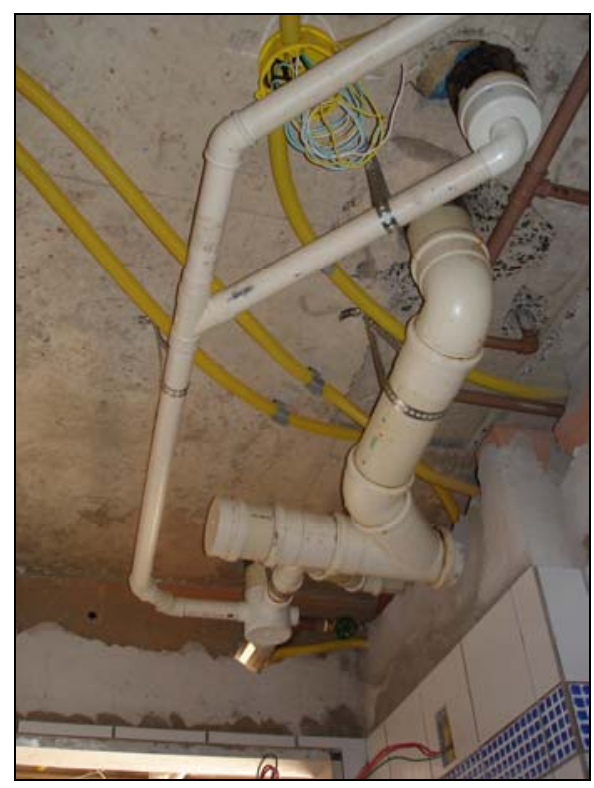

(a)

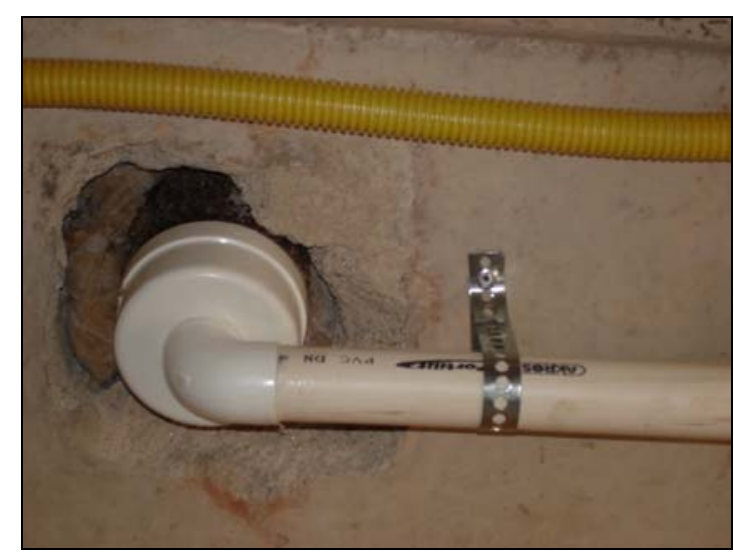

(b)

Figura 5.31 - Execução dos ramais de esgoto - SP0401: (a) Ramais de esgoto do banheiro; (b) detalhe da fixação da tubulação na laje

\subsection{Composição das equipes de trabalho}

Neste item é descrita a composição da equipe executora dos sistemas prediais nas obras onde se realizou o estudo da produtividade da mão-de-obra. Cabe destacar que em todas as obras a execução destes sistemas ficou sobre a responsabilidade de subempreiteiras contratada para tal.

Além da composição, são descritas em linhas gerais, as funções de cada operário durante o período em que se realizou o estudo da produtividade. Por comodidade, 
optou-se em identificá-los pelo próprio nome ou apelido, tal como se anotou nas planilhas de coleta e não por um código específico.

\subsubsection{SP0101}

A equipe encarregada pela execução dos sistemas prediais hidráulicos e sanitários da obra SP0101 era formada, além do encarregado, por mais 19 operários, dentre os quais 9 oficiais, 3 meio-oficiais e 7 ajudantes (Tabela 5.9).

Tabela 5.9 - Composição da equipe de trabalho - SP0101

\begin{tabular}{|c|c|c|}
\hline Número & Nome & Cargo \\
\hline 1 & Clemente & Encarregado \\
\hline 2 & Gilmar & Oficial \\
\hline 3 & Solinha & Oficial \\
\hline 4 & Expedito & Oficial \\
\hline 5 & Geraldo & Oficial \\
\hline 6 & Givano & Oficial \\
\hline 7 & José Hélio & Oficial \\
\hline 8 & Luís José & Oficial \\
\hline 9 & Augustino & Oficial \\
\hline 10 & Luís & Oficial \\
\hline 11 & Antônio Edmilson & $1 / 2$ Oficial \\
\hline 12 & Sabino & $1 / 2$ Oficial \\
\hline 13 & Manuel Fortuoso & 1/2 Oficial \\
\hline 14 & Cícero & Ajudante \\
\hline 15 & Erivonaldo & Ajudante \\
\hline 16 & Ivan & Ajudante \\
\hline 17 & Reginaldo & Ajudante \\
\hline 18 & Ruimar & Ajudante \\
\hline 19 & Tião & Ajudante \\
\hline 20 & Gilson & Ajudante \\
\hline
\end{tabular}


O encarregado não participava diretamente da execução dos serviços e sua função basicamente residia na programação diária dos serviços, além de relacionar diretamente com o engenheiro responsável pela obra.

A equipe era organizada da seguinte forma:

- Antonio Edmilson: era encarregado de locar e fixar os passantes. Os furos eram feitos por uma empresa especializada com o uso de uma perfuratriz, quando não havia frente de trabalho, era alocado em outros serviços, tais como a colocação de isolante térmico nas tubulações de cobre para o transporte de água quente;

- Augustino e Expedito: formavam uma equipe de execução dos ramais de esgoto no teto;

- Luís José e Cícero: compunha outra equipe fixa na execução das instalações de cobre, principalmente os ramais de distribuição nos apartamentos e prumadas;

- José Hélio e Geraldo: eram encarregados pela marcação dos shafts nas fôrmas, antes da concretagem. Passavam o dia fazendo isto e acompanhando a concretagem;

- Ruimar e Gilmar: após serem alocados em atividades de montagem de tubulação nos pavimentos, receberam a tarefa de produzirem os kits contendo registros e tê misturador do chuveiro e banheira;

- Erivonaldo: execução de ramais de cobre kits e in loco nas paredes e ramais sob o teto;

- Gilson, Givano, Ivan e Manoel Fortuoso: estes têm em comum o fato de permanecerem muito pouco na obra. O Gilson e o Ivan ficaram responsáveis 
pelo corte das paredes. Já o Manoel Fortuoso, quando vinha, se ocupava com a colocação de isolante térmico nas tubulações de cobre para o transporte de água fria. O Givano trabalhou poucos dias na execução das instalações do apartamento do Zelador;

- Luís: este operário circulava pelas várias obras nas quais a subempreiteira estava executando os sistemas prediais com o objetivo de realizar os testes das tubulações de gás;

- Tião: ficou muito pouco na obra, mas no tempo em que trabalhou na mesma ficou encarregado de cortar e rasgar as paredes. Em relação aos outros operários destinados para este serviço, este era muito mais produtivo, principalmente pelo seu porte físico;

- Reginaldo: este operário era o "coringa" do encarregado. Cada dia ele estava alocado em um serviço: cortar parede, prumada de cobre, colocação de isolante térmico, realização de testes etc.;

- Sabino: veio de outra obra para executar os ramais de cobre nas paredes da cozinha e área de serviço;

- Solinha: também ficou muito pouco tempo na obra e se ocupou com a produção de kits e seu assentamento nas paredes, juntamente com o Erivonaldo.

Era prática comum do encarregado "tarefar" os funcionários na execução dos serviços, dentre os quais a produção de kits, ramais de esgoto sob a laje de teto e parede, ramais de distribuição entre outros. 


\subsubsection{SP0201}

A equipe encarregada pela execução dos sistemas prediais hidráulicos e sanitários da obra SP0101 era formada, além dos dois encarregados, por mais 4 operários, dentre os quais 2 oficiais e 2 ajudantes (Tabela 5.10).

Tabela 5.10 - Composição da equipe de trabalho - SP0201

\begin{tabular}{|c|c|c|}
\hline Número & Nome & Cargo \\
\hline 1 & Antônio & Encarregado \\
\hline 2 & Xuxa (José Almir) & Encarregado \\
\hline 3 & Renildo & Oficial \\
\hline 4 & Zé Maria & Oficial \\
\hline 5 & Seu Antônio & Ajudante \\
\hline 6 & Geraldo & Ajudante \\
\hline
\end{tabular}

Ao contrário da equipe da obra anterior, os encarregados desta obra também participavam ativamente da execução dos serviços, assumindo tarefas tais como o chumbamento das tubulações nas paredes com argamassa e produção de kits.

Era prática de alguns dos oficiais ficarem além do horário de expediente normal de trabalho com o propósito de terminar o serviço iniciado. Da mesma forma, era comum trabalharem aos sábados também. Assim, ganhavam hora-extra ou descontavam estas horas adicionais quando necessitassem.

A equipe era organizada da seguinte forma:

- Antonio: embora tivesse a função de encarregado, assumiu durante o período de coleta de dados a execução dos ramais de água fria e água quente nas paredes;

- Geraldo: ajudou os encarregados tanto na produção de kits quanto na execução dos ramais e sub-ramais de água fria e água quente nas paredes; 
- Renildo: alocado provisoriamente nesta obra. Durante o curto período em que permaneceu ficou incumbido da execução de ramais de esgoto sob o teto e realização de testes;

- Seu Antonio: ajudou na execução dos ramais de distribuição de água fria e água quente;

- Xuxa (José Almir): embora fosse encarregado, se incumbiu da fixação dos ramais e sub-ramais de água fria, água quente, gás e esgoto nas paredes com argamassa;

- Zé Maria: predominou a execução dos ramais de distribuição de água fria e água quente nos apartamentos-tipo.

\subsubsection{SP0301}

A equipe encarregada pela execução dos sistemas prediais hidráulicos e sanitários da obra SP0301 era formada, além dos dois encarregados, por mais 7 operários, dentre os quais 5 oficiais e 2 ajudantes (Tabela 5.11).

Tabela 5.11 - Composição da equipe de trabalho - SP0301

\begin{tabular}{|c|l|l|}
\hline Número & Nome & Cargo \\
\hline 1 & Osmar & Encarregado \\
\hline 2 & Benedito & Oficial \\
\hline 3 & Carlos & Oficial \\
\hline 4 & Marconi & Oficial \\
\hline 5 & Quaresma & Oficial \\
\hline 6 & Claudemir & Oficial \\
\hline 7 & Antonio & Ajudante \\
\hline 8 & Arlindo & Ajudante \\
\hline
\end{tabular}


O encarregado não participava diretamente da execução dos serviços e sua função basicamente residia na programação diária dos serviços, além de relacionar diretamente com o engenheiro responsável pela obra.

A equipe era organizada da seguinte forma:

- Antonio e Arlindo: compunham uma equipe para a execução dos passantes e os sub-ramais de água fria, água quente e esgoto dos sanitários; Antonio executou também os ramais de água pluvial nos terraços do edifício;

- Benedito: ficou encarregado da execução dos ramais e sub-ramais de água fria e água quente da cozinha e área de serviço;

- Carlos: durante o período de coleta se ocupou com a execução dos ramais de distribuição de água fria e água quente sob o teto;

- Claudemir: foi contratado quando a coleta de dados já estava adiantada. Ocupou-se inicialmente da execução das prumadas nos shafts e assumiu também a execução dos ramais de distribuição de água fria e água quente sob a laje de teto, porém em andar distinto do Carlos, ou seja, não formavam uma equipe trabalhando no mesmo pavimento;

- Marconi: durante o período de coleta de dados este operário foi responsável pela execução dos ramais de esgoto sanitário sob o teto. Alternava este serviço, quando havia falta de material, com o chumbamento das prumadas. Estava descontente com o serviço e acabou demitido antes do fim da coleta de dados realizada por este pesquisador;

- Quaresma: contratado no lugar do Marconi, assumiu a execução dos ramais de esgotos sanitário sob a laje de teto. 


\subsubsection{SP0401}

Ao contrário das outras obras, o encarregado da execução dos sistemas prediais desta obra não permanecia o tempo todo nela, pois era encarregado também da execução destes sistemas em outras obras localizadas, inclusive, em outras cidades.

Sua empresa era responsável também pela execução dos sistemas prediais elétricos e de telefonia. Assim, passava com freqüência na obra, em horários diversos para delegar atribuições aos oficiais e analisar a evolução dos serviços.

A equipe de execução em relação as demais é reduzida, contanto com apenas 4 operários (mas sempre trabalhavam em 3 operários por dia), sendo um deles atuando na execução tanto dos sistemas hidráulicos e sanitários quanto nos sistemas elétricos e de telefonia.

Além desta particularidade em relação ao encarregado, destaca-se ainda o fato de haver dois irmãos trabalhando juntos na execução destes sistemas. A composição desta equipe pode ser visualizada na Tabela 5.12.

Tabela 5.12 - Composição da equipe de trabalho - SP0401

\begin{tabular}{|c|l|l|}
\hline Número & Nome & Cargo \\
\hline 1 & Arara & oficial \\
\hline 2 & Cícero & oficial \\
\hline 3 & Flávio & oficial \\
\hline 4 & Ararinha & ajudante \\
\hline
\end{tabular}

A equipe era organizada da seguinte forma:

- Arara: constitui no oficial mais experiente trabalhando na execução deste serviço. Atuou na execução dos ramais de distribuição de água fria e nos ramais de esgoto sanitário sob o teto; 
- Ararinha: irmão mais novo do operário anterior; ficou encarregado da execução dos passantes e marcação das lajes a serem concretadas;

- Cícero: operário da execução dos sistemas prediais elétricos e de telefonia trabalhou esporadicamente na execução dos sistemas prediais hidráulicos e sanitários nesta obra;

- Flávio: funcionário contratado durante o período de coleta de dados; compõe, juntamente, com o Arara, uma equipe para a execução dos ramais de distribuição de água fria e ramal de esgoto sob o teto. 


\section{Capitulo 6}

\section{RESULTADOS: CONSUMO UNITÁRIO DE MATERIAIS}

Este capítulo é dedicado à apresentação dos resultados relativos ao consumo unitário de materiais (tubos e conexões), no que diz respeito aos seus valores e fatores potencialmente influenciadores.

Considerando os trechos de todos os sistemas prediais envolvidos e todas as obras analisadas, os resultados apresentados neste capítulo são frutos da análise de mais 3.000 registros de trechos de tubulações, cada qual contendo uma série de informações necessárias ao cálculo dos indicadores de consumo.

Pelo fato de a proposta desta tese de estabelecer dois métodos de prognóstico de consumo de materiais em função do nível de informações existentes em cada momento de sua aplicação (estudo de viabilidade e anteprojeto de arquitetura), a seqüência de apresentação dos indicadores de consumo segue o mesmo raciocínio.

Assim, os resultados apresentados neste capítulo são reunidos em três conjuntos distintos, sendo os dois primeiros destinados à elaboração do método simplificado e o último destinado ao método analítico. 
O primeiro conjunto de informações se refere ao indicador metros de tubulação por área de apartamento-tipo $\left(\mathrm{m} / \mathrm{m}^{2}\right.$ de apartamento-tipo) enquanto que o segundo se refere ao número de conexões por área de apartamento-tipo (conexões $\left./ \mathrm{m}^{2}\right)$.

Já o terceiro conjunto de resultados reúne os resultados de consumo de metros de tubulação por pontos atendidos (ou pontos de consumo ou captação), tendo-se como base de levantamento os ambientes dos apartamentos e não o apartamento como um todo, a não ser para o caso dos ramais de distribuição de água fria, água quente e gás.

A este indicador são associados, respectivamente, o indicador relativo ao número de conexões por metro de tubulação, e seus fatores potencialmente influenciadores, tais como a concepção do traçado da tubulação (somente pela parede ou pela parede e teto, aparelhos sanitários em uma única parede ou mais de uma entre outros).

Finalmente, ressalta-se que os valores intermediários utilizados para o cálculo dos indicadores de consumo de materiais apresentados neste capítulo encontram-se no Apêndice D. Ao final deste capítulo são apresentadas as estatísticas gerais (valores máximo, mediana e mínimo) para o conjunto de dados levantados. 
6.1 Metros de tubos por área de apartamento-tipo

\subsubsection{Sistema predial de suprimento de água fria}

\subsubsection{Prumadas}

Tabela 6.1 - Metros de tubos por área de apartamento-tipo: prumadas de água específicas a cada apartamento

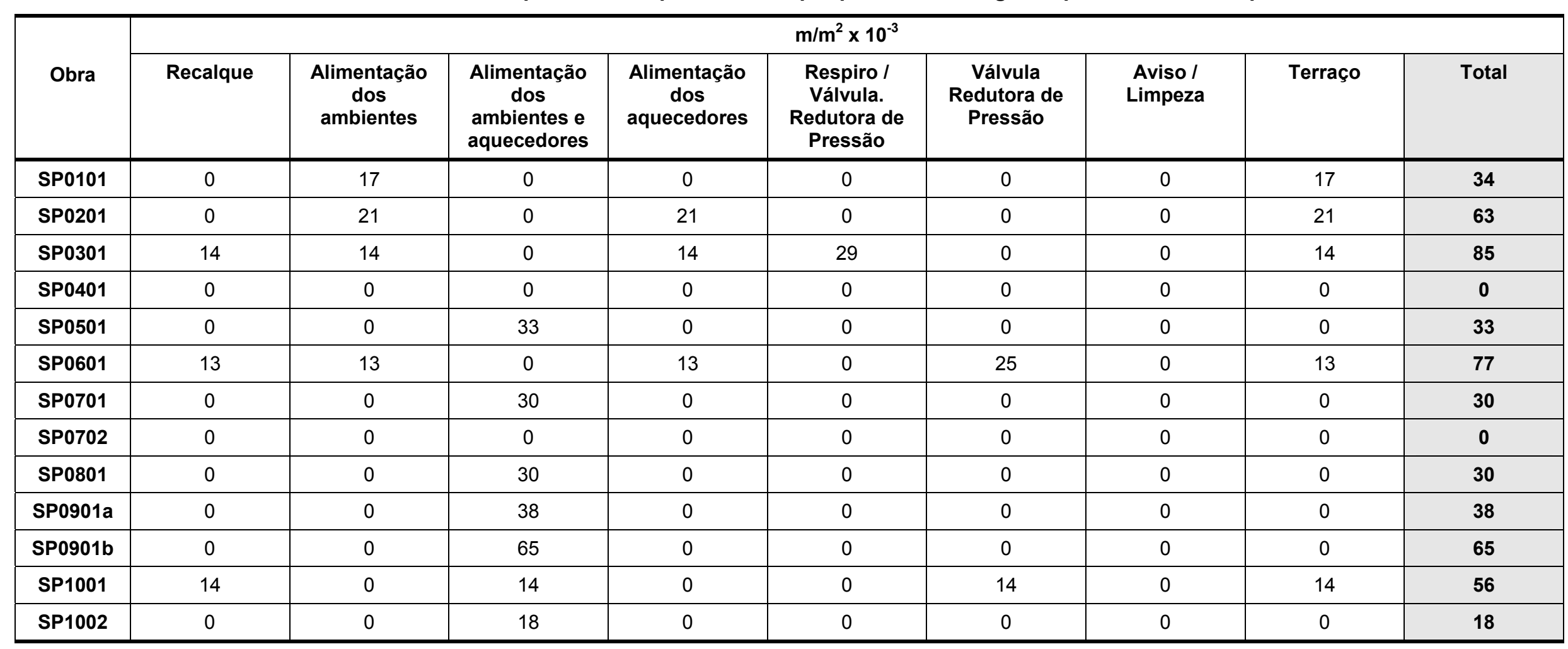


Tabela 6.2 - Metros de tubos por área de apartamento-tipo: prumadas de água fria comuns aos apartamentos

\begin{tabular}{|c|c|c|c|c|c|c|c|c|c|}
\hline \multirow[b]{2}{*}{ Obra } & \multicolumn{9}{|c|}{$\mathrm{m} / \mathrm{m}^{2} \times 10^{-3}$} \\
\hline & Recalque & $\begin{array}{c}\text { Alimentação } \\
\text { dos } \\
\text { ambientes }\end{array}$ & $\begin{array}{c}\text { Alimentação } \\
\text { dos } \\
\text { ambientes e } \\
\text { aquecedores }\end{array}$ & $\begin{array}{c}\text { Alimentação } \\
\text { dos } \\
\text { aquecedores }\end{array}$ & $\begin{array}{c}\text { Respiro / } \\
\text { Válvula. } \\
\text { Redutora de } \\
\text { Pressão }\end{array}$ & $\begin{array}{l}\text { Válvula } \\
\text { Redutora de } \\
\text { Pressão }\end{array}$ & $\begin{array}{c}\text { Aviso / } \\
\text { Limpeza }\end{array}$ & Terraço & Total \\
\hline SP0101 & 8 & 0 & 0 & 8 & 0 & 8 & 0 & 0 & 24 \\
\hline SP0201 & 10 & 0 & 0 & 0 & 0 & 10 & 10 & 0 & 30 \\
\hline SP0301 & 0 & 0 & 0 & 0 & 0 & 0 & 0 & 0 & 0 \\
\hline SP0401 & 10 & 10 & 0 & 0 & 0 & 10 & 10 & 0 & 40 \\
\hline SP0501 & 8 & 0 & 0 & 0 & 0 & 8 & 0 & 0 & 16 \\
\hline SP0601 & 0 & 0 & 0 & 0 & 0 & 0 & 0 & 0 & 0 \\
\hline SP0701 & 15 & 0 & 0 & 0 & 0 & 0 & 15 & 0 & 30 \\
\hline SP0702 & 11 & 0 & 11 & 0 & 0 & 11 & 11 & 0 & 44 \\
\hline SP0801 & 8 & 0 & 0 & 0 & 0 & 0 & 0 & 0 & 8 \\
\hline SP0901a & 6 & 0 & 0 & 0 & 0 & 6 & 6 & 0 & 18 \\
\hline SP0901b & 11 & 0 & 0 & 0 & 0 & 11 & 11 & 0 & 33 \\
\hline SP1001 & 0 & 0 & 0 & 0 & 0 & 0 & 0 & 0 & 0 \\
\hline SP1002 & 9 & 0 & 0 & 0 & 0 & 9 & 9 & 9 & 36 \\
\hline
\end{tabular}




\subsubsection{Ramal de distribuição}

Tabela 6.3 - Metros de tubos por área de apartamento-tipo: ramal de distribuição de água fria

\begin{tabular}{|c|c|c|c|}
\hline \multirow{2}{*}{ Obra } & \multicolumn{3}{|c|}{$\mathrm{m}^{\prime} \mathrm{m}^{2} \times 10^{-3}$} \\
\cline { 2 - 4 } & Sob a laje & $\begin{array}{c}\text { Alimentação dos } \\
\text { aquecedores }\end{array}$ & Total \\
\hline SP0101 & 200 & 0 & $\mathbf{2 0 0}$ \\
\hline SP0201 & 175 & 39 & $\mathbf{2 1 4}$ \\
\hline SP0301 & 194 & 18 & $\mathbf{2 0 4}$ \\
\hline SP0401 & 204 & 0 & $\mathbf{2 9 1}$ \\
\hline SP0501 & 272 & 19 & $\mathbf{1 2 9}$ \\
\hline SP0601 & 119 & 10 & $\mathbf{2 8 3}$ \\
\hline SP0701 & 264 & 19 & $\mathbf{3 3 1}$ \\
\hline SP0702 & 315 & 16 & $\mathbf{2 0 6}$ \\
\hline SP0801 & 194 & 12 & $\mathbf{3 4 3}$ \\
\hline SP0901a & 323 & 20 & $\mathbf{3 9 0}$ \\
\hline SP0901b & 335 & 55 & $\mathbf{2 8 6}$ \\
\hline SP1001 & 223 & 63 & $\mathbf{2 3 5}$ \\
\hline SP1002 & 154 & 81 & \\
\hline
\end{tabular}




\subsubsection{Ramais e sub-ramais}

Tabela 6.4 - Metros de tubos por área de apartamento-tipo: ramais e sub-ramais de água fria

\begin{tabular}{|c|c|c|c|c|c|c|c|c|c|c|c|c|}
\hline \multirow{3}{*}{ Obra } & \multicolumn{12}{|c|}{$\mathrm{m} / \mathrm{m}^{2} \times 10^{-3}$} \\
\hline & \multicolumn{6}{|c|}{ Banheiros social e das suítes } & \multirow{2}{*}{$\begin{array}{l}\text { Banheiro de } \\
\text { Empregada }\end{array}$} & \multirow[t]{2}{*}{ Lavabo } & \multirow{2}{*}{$\begin{array}{l}\text { Área de } \\
\text { serviço }\end{array}$} & \multirow[t]{2}{*}{ Cozinha } & \multirow[t]{2}{*}{ Terraço } & \multirow[t]{2}{*}{ Total } \\
\hline & Social & Suíte 1 & Suíte 2 & Suíte 3 & Suíte 4 & Total & & & & & & \\
\hline SP0101 & 48 & 53 & 27 & 0 & 0 & 128 & 25 & 17 & 21 & 34 & 6 & 231 \\
\hline SP0201 & 0 & 58 & 34 & 38 & 0 & 130 & 32 & 29 & 29 & 44 & 15 & 279 \\
\hline SP0301 & 33 & 74 & 33 & 0 & 0 & 140 & 37 & 27 & 15 & 45 & 1 & 265 \\
\hline SP0401 & 104 & 84 & 0 & 0 & 0 & 188 & 0 & 0 & 51 & 81 & 0 & 320 \\
\hline SP0501 & 46 & 65 & 0 & 0 & 0 & 111 & 45 & 0 & 22 & 56 & 0 & 234 \\
\hline SP0601 & 26 & 33 & 28 & 0 & 0 & 87 & 32 & 14 & 10 & 26 & 24 & 193 \\
\hline SP0701 & 61 & 81 & 0 & 0 & 0 & 142 & 60 & 47 & 22 & 91 & 0 & 362 \\
\hline SP0702 & 47 & 55 & 38 & 0 & 0 & 140 & 43 & 32 & 14 & 23 & 0 & 252 \\
\hline SP0801 & 52 & 52 & 0 & 0 & 0 & 104 & 61 & 33 & 17 & 38 & 0 & 253 \\
\hline SP0901a & 83 & 70 & 0 & 0 & 0 & 153 & 82 & 0 & 22 & 8 & 0 & 265 \\
\hline SP0901b & 121 & 0 & 0 & 0 & 0 & 121 & 0 & 0 & 30 & 13 & 0 & 164 \\
\hline SP1001 & 0 & 41 & 33 & 33 & 31 & 138 & 30 & 20 & 17 & 16 & 9 & 230 \\
\hline SP1002 & 29 & 55 & 37 & 0 & 0 & 121 & 48 & 46 & 17 & 56 & 9 & 297 \\
\hline
\end{tabular}




\subsubsection{Sistema predial de suprimento de água quente}

Tabela 6.5 - Metros de tubos por área de apartamento-tipo: sistema predial de suprimento de água quente

\begin{tabular}{|c|c|c|c|c|c|c|c|c|c|c|c|c|c|c|}
\hline \multirow{3}{*}{ Obra } & \multicolumn{14}{|c|}{$\mathrm{m} / \mathrm{m}^{2} \times 10^{-3}$} \\
\hline & \multirow[b]{2}{*}{ Prumadas } & \multicolumn{3}{|c|}{ Ramal de distribuição } & \multicolumn{6}{|c|}{ Ramais banheiros } & \multirow[b]{2}{*}{ Lavabo } & \multirow[b]{2}{*}{ Coz. } & \multirow{2}{*}{$\begin{array}{c}\text { Total } \\
\text { ramais }\end{array}$} & \multirow[b]{2}{*}{ Geral } \\
\hline & & $\begin{array}{l}\text { Distrib. } \\
\text { sob laje }\end{array}$ & Retorno & Total & Social & Suíte 1 & Suíte 2 & Suíte 3 & Suíte 4 & Empreg. & & & & \\
\hline SP0101 & 67 & 183 & 40 & 223 & 50 & 57 & 27 & 0 & 0 & 16 & 0 & 20 & 170 & 460 \\
\hline SP0201 & - & 193 & 0 & 193 & 0 & 59 & 34 & 30 & 0 & 0 & 0 & 44 & 167 & 360 \\
\hline SP0301 & - & 153 & 0 & 153 & 35 & 73 & 34 & 0 & 0 & 0 & 0 & 21 & 163 & 316 \\
\hline SP0401 & - & - & - & - & - & - & - & - & - & - & - & - & - & - \\
\hline SP0501 & - & 153 & 0 & 153 & 52 & 55 & 0 & 0 & 0 & 0 & 0 & 36 & 143 & 296 \\
\hline SP0601 & - & 74 & 0 & 74 & 26 & 38 & 28 & 0 & 0 & 0 & 0 & 0 & 92 & 166 \\
\hline SP0701 & - & 163 & 0 & 163 & 61 & 79 & 0 & 0 & 0 & 0 & 0 & 45 & 185 & 348 \\
\hline SP0702 & - & 198 & 0 & 198 & 51 & 54 & 44 & 0 & 0 & 0 & 0 & 7 & 156 & 354 \\
\hline SP0801 & - & 178 & 0 & 178 & 55 & 55 & 0 & 0 & 0 & 0 & 0 & 32 & 142 & 320 \\
\hline SP0901a & - & 176 & 0 & 176 & 110 & 108 & 0 & 0 & 0 & 0 & 0 & 8 & 226 & 402 \\
\hline SP0901b & - & 340 & 0 & 340 & 186 & 0 & 0 & 0 & 0 & 0 & 0 & 13 & 199 & 539 \\
\hline SP1001 & - & 175 & 187 & 362 & 0 & 42 & 32 & 27 & 34 & 0 & 17 & 16 & 168 & 530 \\
\hline SP1002 & - & 152 & 120 & 272 & 31 & 55 & 25 & 0 & 0 & 0 & 0 & 23 & 134 & 406 \\
\hline
\end{tabular}




\subsubsection{Sistema predial de suprimento de gás}

Tabela 6.6 - Metros de tubos por área de apartamento-tipo: sistema predial de suprimento de gás

\begin{tabular}{|c|c|c|c|c|c|c|c|c|}
\hline \multirow{3}{*}{ Obra } & \multicolumn{8}{|c|}{$\mathrm{m} / \mathrm{m}^{2} \times 10^{-3}$} \\
\hline & \multicolumn{3}{|c|}{ Prumadas } & \multirow[t]{2}{*}{ Distribuição } & \multicolumn{3}{|c|}{ Ramais } & \multirow[t]{2}{*}{ Total Gera } \\
\hline & $\begin{array}{c}\text { Específicas ao } \\
\text { apto. }\end{array}$ & $\begin{array}{c}\text { Comum aos } \\
\text { aptos. }\end{array}$ & Total & & Aquecedor & Fogão & Total & \\
\hline SP0101 & 17 & 0 & 17 & 14 & 16 & 3 & 19 & 50 \\
\hline SP0201 & 21 & 0 & 21 & 22 & 5 & 19 & 24 & 67 \\
\hline SP0301 & 14 & 0 & 14 & 18 & 27 & 16 & 43 & 75 \\
\hline SP0601 & 13 & 0 & 13 & 5 & 7 & 31 & 38 & 56 \\
\hline SP0701 & 30 & 0 & 30 & 15 & 4 & 1 & 5 & 50 \\
\hline SP0702 & 0 & 11 & 11 & 89 & 19 & 11 & 30 & 130 \\
\hline SP0801 & 30 & 0 & 30 & 23 & 23 & 25 & 48 & 101 \\
\hline SP0901a & 38 & 0 & 38 & 16 & 6 & 68 & 74 & 128 \\
\hline
\end{tabular}




\subsubsection{Sistema predial de prevenção e combate a incêndios}

Tabela 6.7 - Metros de tubos por área de apartamento-tipo e número de conexões por metro de tubulação: sistema predial de prevenção e combate a incêndios

\begin{tabular}{|c|c|c|}
\hline Obra & Metros de prumadas & $\mathrm{m} / \mathrm{m}^{2} \times 10^{-3}$ \\
\hline SP0101 & 1,44 & $\mathbf{8}$ \\
\hline SP0201 & 1,40 & $\mathbf{1 0}$ \\
\hline SP0301 & 2,88 & $\mathbf{1 4}$ \\
\hline SP0401 & 0,74 & $\mathbf{1 0}$ \\
\hline SP0501 & 0,69 & $\mathbf{8}$ \\
\hline SP0601 & 2,88 & $\mathbf{1 3}$ \\
\hline SP0701 & 1,40 & $\mathbf{1 5}$ \\
\hline SP0702 & 1,40 & $\mathbf{1 1}$ \\
\hline SP0801 & 0,70 & $\mathbf{8}$ \\
\hline SP0901a & 0,99 & $\mathbf{1 3}$ \\
\hline SP0901b & 0,99 & $\mathbf{2 2}$ \\
\hline SP1001 & 3,00 & $\mathbf{1 4}$ \\
\hline SP1002 & 1,48 & $\mathbf{9}$ \\
\hline
\end{tabular}




\subsubsection{Sistema predial de coleta de esgoto sanitário}

\subsubsection{Tubos de queda e colunas de ventilação}

Tabela 6.8 - Metros de tubos por área de apartamento-tipo: tubos de queda e coluna de ventilação

\begin{tabular}{|c|c|c|c|c|c|c|c|c|c|c|}
\hline \multirow[t]{3}{*}{ Obra } & \multicolumn{10}{|c|}{$\mathrm{m} / \mathrm{m}^{2} \times 10^{-3}$} \\
\hline & \multicolumn{5}{|c|}{ Tubos de queda e colunas de ventilação comuns aos apartamentos } & \multicolumn{5}{|c|}{ Tubos de queda e colunas de ventilação específicos a cada apartamento } \\
\hline & $\mathrm{EE}$ & EG & ES & VES & Total & EE & EG & ES & VES & Total \\
\hline SP0201 & 0 & 0 & 0 & 0 & 0 & 21 & 41 & 62 & 84 & 208 \\
\hline SP0301 & 0 & 0 & 0 & 0 & 0 & 29 & 14 & 72 & 77 & 192 \\
\hline SP0401 & 0 & 0 & 0 & 0 & 0 & 40 & 40 & 40 & 54 & 174 \\
\hline SP0601 & 0 & 0 & 0 & 0 & 0 & 25 & 25 & 51 & 69 & 170 \\
\hline SP0701 & 0 & 0 & 15 & 21 & 36 & 91 & 30 & 91 & 123 & 335 \\
\hline SP0702 & 0 & 0 & 11 & 15 & 26 & 44 & 22 & 67 & 90 & 223 \\
\hline SP0801 & 0 & 0 & 8 & 10 & 18 & 60 & 30 & 60 & 82 & 232 \\
\hline SP0901a & 0 & 0 & 0 & 8 & 8 & 38 & 38 & 76 & 102 & 254 \\
\hline
\end{tabular}




\subsubsection{Ramais}

Tabela 6.9 - Metros de tubos por área de apartamento-tipo: ramais de esgoto e de ventilação

\begin{tabular}{|c|c|c|c|c|c|c|c|c|c|c|c|c|}
\hline \multirow{3}{*}{ Obra } & \multicolumn{12}{|c|}{$\mathrm{m} / \mathrm{m}^{2} \times 10^{-3}$} \\
\hline & \multicolumn{6}{|c|}{ Banheiros social e das suítes } & \multirow{2}{*}{$\begin{array}{l}\text { Banheiro de } \\
\text { Empregada }\end{array}$} & \multirow[t]{2}{*}{ Lavabo } & \multirow{2}{*}{$\begin{array}{l}\text { Área de } \\
\text { serviço }\end{array}$} & \multirow[t]{2}{*}{ Cozinha } & \multirow{2}{*}{ Terraço } & \multirow{2}{*}{ Total } \\
\hline & Social & Suíte 1 & Suíte 2 & Suíte 3 & Suíte 4 & Total & & & & & & \\
\hline SP0101 & 22 & 52 & 29 & 0 & 0 & 103 & 22 & 18 & 17 & 20 & 0 & 180 \\
\hline SP0201 & 0 & 48 & 34 & 36 & 0 & 118 & 39 & 41 & 64 & 16 & 11 & 289 \\
\hline SP0301 & 28 & 74 & 32 & 0 & 0 & 134 & 21 & 22 & 17 & 29 & 0 & 223 \\
\hline SP0401 & 46 & 69 & 0 & 0 & 0 & 115 & 0 & 0 & 22 & 43 & 0 & 180 \\
\hline SP0501 & 42 & 40 & 0 & 0 & 0 & 82 & 4 & 0 & 23 & 27 & 0 & 136 \\
\hline SP0601 & 17 & 29 & 16 & 0 & 0 & 62 & 19 & 8 & 8 & 14 & 6 & 117 \\
\hline SP0701 & 26 & 52 & 0 & 0 & 0 & 78 & 27 & 19 & 40 & 12 & 0 & 176 \\
\hline SP0702 & 34 & 39 & 32 & 0 & 0 & 105 & 27 & 24 & 43 & 6 & 0 & 205 \\
\hline SP0801 & 27 & 27 & 0 & 0 & 0 & 54 & 15 & 15 & 5 & 8 & 0 & 97 \\
\hline SP0901a & 42 & 32 & 0 & 0 & 0 & 74 & 32 & 0 & 60 & 39 & 0 & 205 \\
\hline SP0901b & 56 & 0 & 0 & 0 & 0 & 56 & 0 & 0 & 27 & 42 & 0 & 125 \\
\hline SP1001 & 0 & 49 & 15 & 27 & 17 & 108 & 16 & 11 & 35 & 18 & 0 & 188 \\
\hline SP1002 & 16 & 38 & 27 & 0 & 0 & 81 & 28 & 17 & 14 & 11 & 6 & 157 \\
\hline
\end{tabular}




\subsubsection{Sistema predial de coleta de águas pluviais}

Tabela 6.10 - Metros de tubos por área de apartamento-tipo: tubos de queda

\begin{tabular}{|c|c|c|c|c|c|c|c|c|c|}
\hline \multirow{3}{*}{ Obra } & \multicolumn{9}{|c|}{$\mathrm{m} / \mathrm{m}^{2} \times 10^{-3}$} \\
\hline & \multicolumn{3}{|c|}{$\begin{array}{c}\text { Tubos de queda específicos a cada } \\
\text { apartamento }\end{array}$} & \multicolumn{3}{|c|}{ Tubos de queda comuns a todos apartamentos } & \multicolumn{3}{|c|}{$\begin{array}{l}\text { Tubos de queda comuns aos apartamentos } \\
\text { adjacentes }\end{array}$} \\
\hline & $\begin{array}{l}\text { Captação } \\
\text { comente da } \\
\text { cobertura }\end{array}$ & $\begin{array}{c}\text { Captação } \\
\text { somente dos } \\
\text { terraços }\end{array}$ & $\begin{array}{c}\text { Captação da } \\
\text { cobertura e } \\
\text { terraços }\end{array}$ & $\begin{array}{l}\text { Captação } \\
\text { comente da } \\
\text { cobertura }\end{array}$ & $\begin{array}{c}\text { Captação } \\
\text { somente dos } \\
\text { terraços }\end{array}$ & $\begin{array}{l}\text { Captação da } \\
\text { cobertura e } \\
\text { terraços }\end{array}$ & $\begin{array}{l}\text { Captação } \\
\text { comente da } \\
\text { cobertura }\end{array}$ & $\begin{array}{c}\text { Captação } \\
\text { somente dos } \\
\text { terraços }\end{array}$ & $\begin{array}{c}\text { Captação da } \\
\text { cobertura e } \\
\text { terraços }\end{array}$ \\
\hline SP0101 & 50 & 33 & 0 & 0 & 0 & 0 & 0 & 0 & 0 \\
\hline SP0201 & 62 & 0 & 21 & 0 & 0 & 0 & 0 & 0 & 0 \\
\hline SP0301 & 29 & 29 & 14 & 0 & 0 & 0 & 0 & 0 & 0 \\
\hline SP0401 & 40 & 0 & 0 & 0 & 0 & 0 & 0 & 20 & 0 \\
\hline SP0501 & 33 & 0 & 0 & 0 & 0 & 0 & 0 & 17 & 0 \\
\hline SP0601 & 51 & 51 & 0 & 0 & 0 & 0 & 0 & 0 & 0 \\
\hline SP0701 & 60 & 60 & 0 & 30 & 0 & 0 & 0 & 0 & 0 \\
\hline SP0702 & 67 & 0 & 0 & 0 & 11 & 0 & 0 & 0 & 0 \\
\hline SP0801 & 60 & 30 & 0 & 0 & 0 & 0 & 0 & 0 & 0 \\
\hline SP0901a & 38 & 38 & 0 & 0 & 0 & 0 & 19 & 0 & 0 \\
\hline SP0901b & 0 & 65 & 0 & 0 & 0 & 0 & 0 & 0 & 0 \\
\hline SP1001 & 42 & 42 & 14 & 0 & 0 & 0 & 0 & 0 & 0 \\
\hline SP1002 & 36 & 54 & 0 & 0 & 0 & 9 & 0 & 0 & 0 \\
\hline
\end{tabular}


Tabela 6.11 - Metros de tubos por área de apartamento-tipo: resumo dos tubos de queda e ramais

\begin{tabular}{|c|c|c|c|c|c|c|c|c|c|c|c|}
\hline \multirow[t]{3}{*}{ Obra } & \multicolumn{11}{|c|}{$\mathrm{m} / \mathrm{m}^{2} \times 10^{-3}$} \\
\hline & \multicolumn{4}{|c|}{ Total: tubos de queda } & \multicolumn{6}{|c|}{ Ramais dos terraços } & \multirow[t]{2}{*}{ Total Geral } \\
\hline & $\begin{array}{c}\text { Específicos } \\
\text { a cada } \\
\text { apto. }\end{array}$ & $\begin{array}{c}\text { Comuns a } \\
\text { todos } \\
\text { aptos. }\end{array}$ & $\begin{array}{l}\text { Comuns } \\
\text { aos aptos. } \\
\text { adjacentes }\end{array}$ & Geral & $\begin{array}{l}\text { Área de } \\
\text { serviço }\end{array}$ & Dormitório & $\begin{array}{c}\text { Sala de } \\
\text { estar }\end{array}$ & $\begin{array}{l}\text { Sala de } \\
\text { jantar }\end{array}$ & Suíte1 & Total & \\
\hline SP0101 & 83 & 0 & 0 & 83 & 0 & 0 & 34 & 0 & 2 & 36 & 119 \\
\hline SP0201 & 83 & 0 & 0 & 83 & 0 & 0 & 34 & 0 & 0 & 34 & 117 \\
\hline SP0301 & 72 & 0 & 0 & 72 & 3 & 0 & 26 & 0 & 1 & 30 & 102 \\
\hline SP0401 & 40 & 0 & 20 & 60 & 0 & 0 & 1 & 0 & 0 & 1 & 61 \\
\hline SP0501 & 33 & 0 & 17 & 50 & 0 & 0 & 1 & 0 & 0 & 1 & 51 \\
\hline SP0601 & 102 & 0 & 0 & 102 & 1 & 0 & 1 & 0 & 1 & 3 & 105 \\
\hline SP0701 & 120 & 30 & 0 & 150 & 0 & 0 & 3 & 3 & 0 & 6 & 156 \\
\hline SP0702 & 67 & 11 & 0 & 78 & 0 & 0 & 2 & 0 & 0 & 2 & 80 \\
\hline SP0801 & 90 & 0 & 0 & 90 & 0 & 0 & 2 & 0 & 0 & 2 & 92 \\
\hline SP0901a & 76 & 0 & 19 & 95 & 0 & 0 & 3 & 0 & 0 & 3 & 98 \\
\hline SP0901b & 65 & 0 & 0 & 65 & 0 & 0 & 4 & 0 & 0 & 4 & 69 \\
\hline SP1001 & 98 & 0 & 0 & 98 & 0 & 0 & 1 & 5 & 1 & 7 & 105 \\
\hline SP1002 & 90 & 9 & 0 & 99 & 2 & 2 & 2 & 0 & 2 & 8 & 107 \\
\hline
\end{tabular}


6.2 Número de conexões por área de apartamento-tipo

\subsubsection{Sistema predial de suprimento de água fria}

\subsubsection{Prumadas}

Tabela 6.12 - Número de conexões por área de apartamento-tipo: prumadas de água fria específicas a cada apartamento

\begin{tabular}{|c|c|c|c|c|c|c|c|c|c|}
\hline \multirow[b]{2}{*}{ Obra } & \multicolumn{9}{|c|}{ Conexões $/ \mathrm{m}^{2} \times 10^{-3}$} \\
\hline & Recalque & $\begin{array}{c}\text { Alimentação } \\
\text { dos } \\
\text { ambientes }\end{array}$ & $\begin{array}{c}\text { Alimentação } \\
\text { dos } \\
\text { ambientes e } \\
\text { aquecedores }\end{array}$ & $\begin{array}{c}\text { Alimentação } \\
\text { dos } \\
\text { aquecedores }\end{array}$ & $\begin{array}{c}\text { Respiro / } \\
\text { Válvula. } \\
\text { Redutora de } \\
\text { Pressão }\end{array}$ & $\begin{array}{l}\text { Válvula } \\
\text { Redutora de } \\
\text { Pressão }\end{array}$ & $\begin{array}{c}\text { Aviso / } \\
\text { Limpeza }\end{array}$ & Terraço & Total \\
\hline SP0101 & 0 & 6 & 0 & 0 & 0 & 0 & 0 & 6 & 12 \\
\hline SP0201 & 0 & 7 & 0 & 7 & 0 & 0 & 0 & 7 & 21 \\
\hline SP0301 & 5 & 5 & 0 & 5 & 0 & 10 & 0 & 5 & 30 \\
\hline SP0401 & 0 & 0 & 0 & 0 & 0 & 0 & 0 & 0 & 0 \\
\hline SP0501 & 0 & 0 & 12 & 0 & 0 & 0 & 0 & 0 & 12 \\
\hline SP0601 & 4 & 4 & 0 & 4 & 0 & 9 & 0 & 4 & 25 \\
\hline SP0701 & 0 & 0 & 11 & 0 & 0 & 0 & 0 & 0 & 11 \\
\hline SP0702 & 0 & 0 & 0 & 0 & 0 & 0 & 0 & 0 & 0 \\
\hline SP0801 & 0 & 0 & 11 & 0 & 0 & 0 & 0 & 0 & 11 \\
\hline SP0901a & 0 & 0 & 13 & 0 & 0 & 0 & 0 & 0 & 13 \\
\hline SP0901b & 0 & 0 & 22 & 0 & 0 & 0 & 0 & 0 & 22 \\
\hline SP1001 & 5 & 0 & 5 & 0 & 0 & 5 & 0 & 5 & 20 \\
\hline SP1002 & 0 & 0 & 6 & 0 & 0 & 0 & 0 & 0 & 6 \\
\hline
\end{tabular}


Tabela 6.13 - Número de conexões por área de apartamento-tipo: prumadas de água fria comuns aos apartamentos

\begin{tabular}{|c|c|c|c|c|c|c|c|c|c|}
\hline \multirow[b]{2}{*}{ Obra } & \multicolumn{9}{|c|}{ Conexões $/ \mathrm{m}^{2} \times 10^{-3}$} \\
\hline & Recalque & $\begin{array}{c}\text { Alimentação } \\
\text { dos } \\
\text { ambientes }\end{array}$ & $\begin{array}{c}\text { Alimentação } \\
\text { dos } \\
\text { ambientes e } \\
\text { aquecedores }\end{array}$ & $\begin{array}{l}\text { Alimentação } \\
\text { dos } \\
\text { aquecedores }\end{array}$ & $\begin{array}{c}\text { Respiro / } \\
\text { Válvula. } \\
\text { Redutora de } \\
\text { Pressão }\end{array}$ & $\begin{array}{l}\text { Válvula } \\
\text { Redutora de } \\
\text { Pressão }\end{array}$ & $\begin{array}{c}\text { Aviso / } \\
\text { Limpeza }\end{array}$ & Terraço & Total \\
\hline SP0101 & 3 & 0 & 0 & 3 & 0 & 3 & 0 & 0 & 9 \\
\hline SP0201 & 4 & 0 & 0 & 0 & 0 & 4 & 4 & 0 & 12 \\
\hline SP0301 & 0 & 0 & 0 & 0 & 0 & 0 & 0 & 0 & 0 \\
\hline SP0401 & 4 & 4 & 0 & 0 & 0 & 4 & 4 & 0 & 16 \\
\hline SP0501 & 4 & 0 & 0 & 0 & 0 & 4 & 0 & 0 & 8 \\
\hline SP0601 & 0 & 0 & 0 & 0 & 0 & 0 & 0 & 0 & 0 \\
\hline SP0701 & 5 & 0 & 0 & 0 & 0 & 0 & 5 & 0 & 10 \\
\hline SP0702 & 4 & 0 & 4 & 0 & 0 & 4 & 4 & 0 & 16 \\
\hline SP0801 & 3 & 0 & 0 & 0 & 0 & 0 & 0 & 0 & 3 \\
\hline SP0901a & 3 & 0 & 0 & 0 & 0 & 3 & 3 & 0 & 9 \\
\hline SP0901b & 4 & 0 & 0 & 0 & 0 & 4 & 4 & 0 & 12 \\
\hline SP1001 & 0 & 0 & 0 & 0 & 0 & 0 & 0 & 0 & 0 \\
\hline SP1002 & 3 & 0 & 0 & 0 & 0 & 3 & 3 & 6 & 15 \\
\hline
\end{tabular}




\subsubsection{Ramal de distribuição}

Tabela 6.14 - Número de conexões por área de apartamento-tipo: ramal de distribuição de água fria

\begin{tabular}{|c|c|c|c|}
\hline \multirow{2}{*}{ Obra } & \multicolumn{3}{|c|}{ Conexões $/ \mathrm{m}^{2} \times 10^{-3}$} \\
\cline { 2 - 4 } & Sob a laje & $\begin{array}{c}\text { Alimentação dos } \\
\text { aquecedores }\end{array}$ & Total \\
\hline SP0101 & 178 & 0 & $\mathbf{1 7 8}$ \\
\hline SP0201 & 193 & 74 & $\mathbf{2 6 7}$ \\
\hline SP0301 & 170 & 55 & $\mathbf{2 7 0}$ \\
\hline SP0401 & 270 & 0 & $\mathbf{4 6 2}$ \\
\hline SP0501 & 389 & 73 & $\mathbf{1 7 3}$ \\
\hline SP0601 & 133 & 40 & $\mathbf{3 6 7}$ \\
\hline SP0701 & 291 & 76 & $\mathbf{3 5 0}$ \\
\hline SP0702 & 294 & 56 & $\mathbf{3 4 8}$ \\
\hline SP0801 & 261 & 87 & $\mathbf{4 4 7}$ \\
\hline SP0901a & 396 & 51 & $\mathbf{5 4 9}$ \\
\hline SP0901b & 417 & 132 & $\mathbf{2 8 2}$ \\
\hline SP1001 & 188 & 94 & $\mathbf{2 6 6}$ \\
\hline SP1002 & 145 & 121 & \\
\hline
\end{tabular}




\subsubsection{Ramal e sub-ramais}

Tabela 6.15 - Número de conexões por área de apartamento-tipo: ramais e sub-ramais de água fria

\begin{tabular}{|c|c|c|c|c|c|c|c|c|c|c|c|c|}
\hline \multirow{3}{*}{ Obra } & \multicolumn{12}{|c|}{ Conexões $/ \mathrm{m}^{2} \times 10^{-3}$} \\
\hline & \multicolumn{6}{|c|}{ Banheiros social e das suítes } & \multirow{2}{*}{$\begin{array}{l}\text { Banheiro de } \\
\text { Empregada }\end{array}$} & \multirow[t]{2}{*}{ Lavabo } & \multirow{2}{*}{$\begin{array}{l}\text { Área de } \\
\text { serviço }\end{array}$} & \multirow[t]{2}{*}{ Cozinha } & \multirow[t]{2}{*}{ Terraço } & \multirow[t]{2}{*}{ Total } \\
\hline & Social & Suíte 1 & Suíte 2 & Suíte 3 & Suíte 4 & Total & & & & & & \\
\hline SP0101 & 109 & 127 & 86 & 0 & 0 & 322 & 75 & 29 & 46 & 69 & 29 & 570 \\
\hline SP0201 & 0 & 163 & 111 & 126 & 0 & 400 & 96 & 67 & 74 & 74 & 67 & 778 \\
\hline SP0301 & 75 & 135 & 90 & 0 & 0 & 300 & 70 & 55 & 45 & 120 & 5 & 595 \\
\hline SP0401 & 216 & 176 & 0 & 0 & 0 & 392 & 0 & 0 & 54 & 135 & 0 & 581 \\
\hline SP0501 & 195 & 207 & 0 & 0 & 0 & 402 & 134 & 0 & 85 & 134 & 0 & 755 \\
\hline SP0601 & 84 & 106 & 80 & 0 & 0 & 270 & 75 & 31 & 31 & 93 & 49 & 549 \\
\hline SP0701 & 162 & 173 & 0 & 0 & 0 & 335 & 151 & 97 & 43 & 162 & 0 & 788 \\
\hline SP0702 & 111 & 151 & 135 & 0 & 0 & 397 & 111 & 103 & 40 & 48 & 0 & 699 \\
\hline SP0801 & 185 & 185 & 0 & 0 & 0 & 370 & 163 & 109 & 76 & 196 & 0 & 914 \\
\hline SP0901a & 230 & 230 & 0 & 0 & 0 & 460 & 204 & 0 & 102 & 26 & 0 & 792 \\
\hline SP0901b & 395 & 0 & 0 & 0 & 0 & 395 & 0 & 0 & 88 & 44 & 0 & 527 \\
\hline SP1001 & 0 & 113 & 113 & 113 & 117 & 456 & 66 & 52 & 52 & 47 & 19 & 692 \\
\hline SP1002 & 97 & 133 & 103 & 0 & 0 & 333 & 97 & 66 & 48 & 127 & 30 & 701 \\
\hline
\end{tabular}


6.2.2 Sistema Predial de suprimento de água quente

Tabela 6.16 - Número de conexões por área de apartamento-tipo - sistema predial de suprimento de água quente

\begin{tabular}{|c|c|c|c|c|c|c|c|c|c|c|c|c|c|c|}
\hline \multirow{3}{*}{ Obra } & \multicolumn{14}{|c|}{ Conexões $/ \mathrm{m}^{2} \times 10^{-3}$} \\
\hline & \multirow[b]{2}{*}{ Prumadas } & \multicolumn{3}{|c|}{ Ramal de distribuição } & \multicolumn{6}{|c|}{ Ramais banheiros } & \multirow[b]{2}{*}{ Lavabo } & \multirow[b]{2}{*}{ Coz. } & \multirow{2}{*}{$\begin{array}{l}\text { Total } \\
\text { ramais }\end{array}$} & \multirow[b]{2}{*}{ Geral } \\
\hline & & $\begin{array}{l}\text { Distrib. } \\
\text { sob laje }\end{array}$ & Retorno & Total & Social & Suíte 1 & Suíte 2 & Suíte 3 & Suíte 4 & Empreg. & & & & \\
\hline SP0101 & 24 & 121 & 40 & 161 & 92 & 150 & 81 & 0 & 0 & 52 & 0 & 40 & 415 & 600 \\
\hline SP0201 & 0 & 126 & 0 & 126 & 0 & 163 & 96 & 104 & 0 & 0 & 0 & 74 & 437 & 563 \\
\hline SP0301 & 0 & 105 & 0 & 105 & 70 & 140 & 70 & 0 & 0 & 0 & 0 & 40 & 320 & 425 \\
\hline SP0401 & - & - & - & - & - & - & - & - & - & - & - & - & - & - \\
\hline SP0501 & 0 & 207 & 0 & 207 & 170 & 158 & 0 & 0 & 0 & 0 & 0 & 73 & 401 & 608 \\
\hline SP0601 & 0 & 58 & 0 & 58 & 71 & 124 & 71 & 0 & 0 & 0 & 0 & 0 & 266 & 324 \\
\hline SP0701 & 0 & 119 & 0 & 119 & 140 & 151 & 0 & 0 & 0 & 0 & 0 & 86 & 377 & 496 \\
\hline SP0702 & 0 & 111 & 0 & 111 & 95 & 127 & 127 & 0 & 0 & 0 & 0 & 8 & 357 & 468 \\
\hline SP0801 & 0 & 163 & 0 & 163 & 196 & 196 & 0 & 0 & 0 & 0 & 0 & 76 & 468 & 631 \\
\hline SP0901a & 0 & 141 & 0 & 141 & 204 & 204 & 0 & 0 & 0 & 0 & 0 & 13 & 421 & 562 \\
\hline SP0901b & 0 & 351 & 0 & 351 & 351 & 0 & 0 & 0 & 0 & 0 & 0 & 22 & 373 & 724 \\
\hline SP1001 & 0 & 113 & 141 & 254 & 0 & 117 & 99 & 89 & 103 & 0 & 33 & 47 & 488 & 742 \\
\hline SP1002 & 0 & 121 & 302 & 423 & 84 & 127 & 78 & 0 & 0 & 0 & 0 & 42 & 331 & 754 \\
\hline
\end{tabular}


6.2.3 Sistema Predial de suprimento de gás

Tabela 6.17 - Número de conexões por área de apartamento-tipo: sistema predial de suprimento de gás

\begin{tabular}{|c|c|c|c|c|c|c|c|c|}
\hline \multirow{3}{*}{ Obra } & \multicolumn{8}{|c|}{ Conexões $/ \mathrm{m}^{2} \times 10^{-3}$} \\
\hline & \multicolumn{3}{|c|}{ Prumadas } & \multirow[t]{2}{*}{ Distribuição } & \multicolumn{3}{|c|}{ Ramais } & \multirow[t]{2}{*}{ Total Gera } \\
\hline & $\begin{array}{c}\text { Específicas ao } \\
\text { apto. }\end{array}$ & $\begin{array}{c}\text { Comum aos } \\
\text { aptos. }\end{array}$ & Total & & Aquecedor & Fogão & Total & \\
\hline SP0101 & 6 & 0 & 6 & 52 & 17 & 17 & 34 & 92 \\
\hline SP0201 & 7 & 0 & 7 & 59 & 22 & 22 & 44 & 110 \\
\hline SP0301 & 5 & 0 & 5 & 60 & 35 & 35 & 70 & 135 \\
\hline SP0601 & 4 & 0 & 4 & 44 & 22 & 22 & 44 & 92 \\
\hline SP0701 & 11 & 0 & 11 & 54 & 22 & 22 & 44 & 109 \\
\hline SP0702 & 0 & 4 & 4 & 63 & 32 & 24 & 56 & 123 \\
\hline SP0801 & 11 & 0 & 11 & 109 & 65 & 22 & 87 & 207 \\
\hline SP0901a & 13 & 0 & 13 & 51 & 38 & 64 & 102 & 166 \\
\hline
\end{tabular}


6.2.4 Sistema predial de prevenção e combate a incêndios

Tabela 6.18 -Número de conexões por área de apartamento-tipo: sistema predial de prevenção e combate a incêndios

\begin{tabular}{|c|c|c|}
\hline Obra & Número de conexões & Conexões $/ \mathbf{m}^{\mathbf{2}} \mathbf{\times} \mathbf{1 0}^{-3}$ \\
\hline SP0101 & 0,50 & $\mathbf{3}$ \\
\hline SP0201 & 0,50 & $\mathbf{4}$ \\
\hline SP0301 & 1,00 & $\mathbf{5}$ \\
\hline SP0401 & 0,25 & $\mathbf{3}$ \\
\hline SP0501 & 0,25 & $\mathbf{3}$ \\
\hline SP0601 & 1,00 & $\mathbf{4}$ \\
\hline SP0701 & 0,50 & $\mathbf{5}$ \\
\hline SP0702 & 0,50 & $\mathbf{4}$ \\
\hline SP0801 & 0,25 & $\mathbf{3}$ \\
\hline SP0901a & 0,33 & $\mathbf{4}$ \\
\hline SP0901b & 0,33 & $\mathbf{7}$ \\
\hline SP1001 & 1,00 & $\mathbf{5}$ \\
\hline SP1002 & 0,50 & $\mathbf{3}$ \\
\hline
\end{tabular}


6.2.5 Sistema predial de coleta de esgoto sanitário

\subsubsection{Tubos de queda e colunas de ventilação}

Tabela 6.19 - Número de conexões por área de apartamento-tipo: tubos de queda e coluna de ventilação

\begin{tabular}{|c|c|c|c|c|c|c|c|c|c|c|}
\hline \multirow[t]{3}{*}{ Obra } & \multicolumn{10}{|c|}{ Conexões $/ \mathrm{m}^{2} \times 10^{-3}$} \\
\hline & \multicolumn{5}{|c|}{ Tubos de queda e colunas de ventilação comuns aos apartamentos } & \multicolumn{5}{|c|}{ Tubos de queda e colunas de ventilação específicos a cada apartamento } \\
\hline & EE & EG & ES & VES & Total & EE & EG & ES & VES & Total \\
\hline SP0101 & 0 & 0 & 0 & 0 & 0 & 29 & 12 & 127 & 58 & 226 \\
\hline SP0201 & 0 & 0 & 0 & 0 & 0 & 7 & 15 & 59 & 44 & 125 \\
\hline SP0301 & 0 & 0 & 0 & 0 & 0 & 35 & 10 & 50 & 40 & 135 \\
\hline SP0401 & 0 & 0 & 0 & 0 & 0 & 41 & 14 & 68 & 27 & 150 \\
\hline SP0501 & 0 & 0 & 0 & 0 & 0 & 97 & 12 & 36 & 73 & 218 \\
\hline SP0601 & 0 & 0 & 0 & 0 & 0 & 13 & 13 & 18 & 35 & 79 \\
\hline SP0701 & 0 & 0 & 38 & 27 & 65 & 65 & 22 & 86 & 97 & 270 \\
\hline SP0702 & 0 & 0 & 24 & 8 & 32 & 32 & 32 & 71 & 48 & 183 \\
\hline SP0801 & 0 & 0 & 16 & 8 & 24 & 65 & 11 & 43 & 43 & 162 \\
\hline SP0901a & 0 & 0 & 0 & 4 & 4 & 26 & 26 & 51 & 51 & 154 \\
\hline SP0901b & 0 & 0 & 0 & 0 & 0 & 22 & 22 & 44 & 44 & 132 \\
\hline SP1001 & 0 & 0 & 0 & 0 & 0 & 19 & 9 & 38 & 38 & 104 \\
\hline SP1002 & 0 & 12 & 0 & 0 & 12 & 12 & 24 & 139 & 103 & 278 \\
\hline
\end{tabular}




\subsubsection{Ramais}

Tabela 6.20 - Número de conexões por área de apartamento-tipo: ramais de esgoto e de ventilação

\begin{tabular}{|c|c|c|c|c|c|c|c|c|c|c|c|c|}
\hline \multirow{3}{*}{ Obra } & \multicolumn{12}{|c|}{ Conexões $/ \mathrm{m}^{2} \times 10^{-3}$} \\
\hline & \multicolumn{6}{|c|}{ Banheiros social e das suítes } & \multirow{2}{*}{$\begin{array}{l}\text { Banheiro de } \\
\text { Empregada }\end{array}$} & \multirow{2}{*}{ Lavabo } & \multirow{2}{*}{$\begin{array}{l}\text { Área de } \\
\text { serviço }\end{array}$} & \multirow{2}{*}{ Cozinha } & \multirow{2}{*}{ Terraço } & \multirow{2}{*}{$\begin{array}{l}\text { Total } \\
\text { ramais }\end{array}$} \\
\hline & Social & Suíte 1 & Suíte 2 & Suíte 3 & Suíte 4 & Total & & & & & & \\
\hline SP0101 & 58 & 104 & 69 & 0 & 0 & 231 & 58 & 46 & 52 & 58 & 0 & 445 \\
\hline SP0201 & 0 & 133 & 96 & 74 & 0 & 303 & 74 & 74 & 96 & 52 & 22 & 621 \\
\hline SP0301 & 55 & 125 & 60 & 0 & 0 & 240 & 50 & 60 & 80 & 55 & 0 & 485 \\
\hline SP0401 & 230 & 270 & 0 & 0 & 0 & 500 & 0 & 0 & 54 & 81 & 0 & 635 \\
\hline SP0501 & 158 & 134 & 0 & 0 & 0 & 292 & 73 & 0 & 146 & 158 & 0 & 669 \\
\hline SP0601 & 71 & 102 & 71 & 0 & 0 & 244 & 66 & 49 & 49 & 31 & 13 & 452 \\
\hline SP0701 & 97 & 140 & 0 & 0 & 0 & 237 & 130 & 97 & 54 & 76 & 0 & 594 \\
\hline SP0702 & 95 & 95 & 95 & 0 & 0 & 285 & 111 & 87 & 71 & 56 & 0 & 610 \\
\hline SP0801 & 130 & 130 & 0 & 0 & 0 & 260 & 76 & 76 & 54 & 54 & 0 & 520 \\
\hline SP0901a & 128 & 166 & 0 & 0 & 0 & 294 & 141 & 0 & 115 & 64 & 0 & 614 \\
\hline SP0901b & 285 & 0 & 0 & 0 & 0 & 285 & 0 & 0 & 132 & 66 & 0 & 483 \\
\hline SP1001 & 0 & 136 & 84 & 56 & 70 & 346 & 61 & 56 & 52 & 38 & 0 & 553 \\
\hline SP1002 & 48 & 48 & 66 & 0 & 0 & 162 & 91 & 36 & 48 & 60 & 12 & 409 \\
\hline
\end{tabular}




\subsubsection{Sistema predial de coleta de águas pluviais}

Tabela 6.21 - Número de conexões por área de apartamento-tipo: tubos de queda

\begin{tabular}{|c|c|c|c|c|c|c|c|c|c|}
\hline \multirow{3}{*}{ Obra } & \multicolumn{9}{|c|}{ Conexões $/ \mathrm{m}^{2} \times 10^{-3}$} \\
\hline & \multicolumn{3}{|c|}{$\begin{array}{l}\text { Tubos de queda específicos a cada } \\
\text { apartamento }\end{array}$} & \multicolumn{3}{|c|}{ Tubos de queda comuns a todos apartamentos } & \multicolumn{3}{|c|}{$\begin{array}{l}\text { Tubos de queda comuns aos apartamentos } \\
\text { adjacentes }\end{array}$} \\
\hline & $\begin{array}{l}\text { Captação } \\
\text { comente da } \\
\text { cobertura }\end{array}$ & $\begin{array}{c}\text { Captação } \\
\text { somente dos } \\
\text { terraços }\end{array}$ & $\begin{array}{c}\text { Captação da } \\
\text { cobertura e } \\
\text { terraços }\end{array}$ & $\begin{array}{l}\text { Captação } \\
\text { comente da } \\
\text { cobertura }\end{array}$ & $\begin{array}{l}\text { Captação } \\
\text { somente dos } \\
\text { terraços }\end{array}$ & $\begin{array}{l}\text { Captação da } \\
\text { cobertura e } \\
\text { terraços }\end{array}$ & $\begin{array}{l}\text { Captação } \\
\text { comente da } \\
\text { cobertura }\end{array}$ & $\begin{array}{l}\text { Captação } \\
\text { somente dos } \\
\text { terraços }\end{array}$ & $\begin{array}{c}\text { Captação da } \\
\text { cobertura e } \\
\text { terraços }\end{array}$ \\
\hline SP0101 & 17 & 12 & 0 & 0 & 0 & 0 & 0 & 0 & 0 \\
\hline SP0201 & 22 & 0 & 7 & 0 & 0 & 0 & 0 & 0 & 0 \\
\hline SP0301 & 10 & 10 & 5 & 0 & 0 & 0 & 0 & 0 & 0 \\
\hline SP0401 & 14 & 0 & 0 & 0 & 0 & 0 & 0 & 20 & 0 \\
\hline SP0501 & 12 & 0 & 0 & 0 & 0 & 0 & 0 & 36 & 0 \\
\hline SP0601 & 18 & 18 & 0 & 0 & 0 & 0 & 0 & 0 & 0 \\
\hline SP0701 & 22 & 22 & 0 & 11 & 0 & 0 & 0 & 0 & 0 \\
\hline SP0702 & 24 & 0 & 0 & 0 & 16 & 0 & 0 & 0 & 0 \\
\hline SP0801 & 22 & 22 & 0 & 0 & 0 & 0 & 0 & 0 & 0 \\
\hline SP0901a & 13 & 13 & 0 & 0 & 0 & 0 & 6 & 0 & 0 \\
\hline SP0901b & 0 & 22 & 0 & 0 & 0 & 0 & 0 & 0 & 0 \\
\hline SP1001 & 14 & 28 & 9 & 0 & 0 & 0 & 0 & 0 & 0 \\
\hline SP1002 & 12 & 36 & 0 & 0 & 0 & 12 & 0 & 0 & 0 \\
\hline
\end{tabular}


Tabela 6.22 - Número de conexões por área de apartamento-tipo: resumo dos tubos de queda e ramais

\begin{tabular}{|c|c|c|c|c|c|c|c|c|c|c|c|}
\hline \multirow[b]{3}{*}{ Obra } & \multicolumn{11}{|c|}{ Conexões $/ \mathrm{m}^{2} \times 10^{-3}$} \\
\hline & \multicolumn{4}{|c|}{ Total: tubos de queda } & \multicolumn{6}{|c|}{ Ramais dos terraços } & \multirow[b]{2}{*}{ Total Geral } \\
\hline & $\begin{array}{c}\text { Específicos } \\
\text { a cada } \\
\text { apto. }\end{array}$ & $\begin{array}{c}\text { Comuns a } \\
\text { todos } \\
\text { aptos. }\end{array}$ & $\begin{array}{l}\text { Comuns } \\
\text { aos aptos. } \\
\text { adjacentes }\end{array}$ & Geral & $\begin{array}{l}\text { Área de } \\
\text { serviço }\end{array}$ & Dormitório & $\begin{array}{c}\text { Sala de } \\
\text { estar }\end{array}$ & $\begin{array}{l}\text { Sala de } \\
\text { jantar }\end{array}$ & Suíte1 & Total & \\
\hline SP0101 & 29 & 0 & 0 & 29 & 0 & 0 & 17 & 0 & 6 & 23 & 52 \\
\hline SP0201 & 29 & 0 & 0 & 29 & 0 & 0 & 37 & 0 & 0 & 37 & 66 \\
\hline SP0301 & 25 & 0 & 0 & 25 & 5 & 0 & 15 & 0 & 5 & 25 & 50 \\
\hline SP0401 & 14 & 0 & 20 & 34 & 0 & 0 & 14 & 0 & 0 & 14 & 48 \\
\hline SP0501 & 12 & 0 & 36 & 48 & 0 & 0 & 49 & 0 & 0 & 49 & 97 \\
\hline SP0601 & 36 & 0 & 0 & 36 & 4 & 0 & 9 & 0 & 4 & 17 & 53 \\
\hline SP0701 & 44 & 11 & 0 & 55 & 0 & 0 & 11 & 11 & 0 & 22 & 77 \\
\hline SP0702 & 24 & 16 & 0 & 40 & 0 & 0 & 8 & 0 & 0 & 8 & 48 \\
\hline SP0801 & 44 & 0 & 0 & 44 & 0 & 0 & 11 & 0 & 0 & 11 & 55 \\
\hline SP0901a & 26 & 0 & 6 & 32 & 0 & 0 & 13 & 0 & 0 & 13 & 45 \\
\hline SP0901b & 22 & 0 & 0 & 22 & 0 & 0 & 22 & 0 & 0 & 22 & 44 \\
\hline SP1001 & 51 & 0 & 0 & 51 & 0 & 0 & 9 & 5 & 9 & 23 & 74 \\
\hline SP1002 & 48 & 12 & 0 & 60 & 6 & 6 & 6 & 0 & 6 & 24 & 84 \\
\hline
\end{tabular}


6.3 Metros de tubulação por número de pontos de consumo/captação e número de conexões por metro de tubulação

\subsubsection{Sistema predial de suprimento de água fria}

\subsubsection{Ramal de distribuição}

Tabela 6.23 - Indicadores de consumo e fatores potencialmente influenciadores: ramal de distribuição de água fria

\begin{tabular}{|c|c|c|c|c|c|c|c|c|c|}
\hline Obra & $\begin{array}{c}\% \text { de } \\
\text { áreas } \\
\text { molháveis }\end{array}$ & $\begin{array}{l}\text { Compr. } \\
\text { (metros) }\end{array}$ & $\begin{array}{c}\text { Núm. de } \\
\text { ambientes } \\
\text { atendidos }\end{array}$ & $\begin{array}{l}\text { Núm. de conjuntos } \\
\text { de ambientes } \\
\text { molháveis }\end{array}$ & $\begin{array}{l}\text { Número de } \\
\text { conexões }\end{array}$ & $\begin{array}{l}\text { m/ambientes } \\
\text { atendidos }\end{array}$ & $\begin{array}{c}\mathrm{m} / \text { conjunto } \\
\text { de ambientes }\end{array}$ & Conex./metro & $\begin{array}{l}\text { Posição do ramal de } \\
\text { distribuição }\end{array}$ \\
\hline SP0101 & 30,56 & 34,81 & 7 & 3 & 31 & 4,97 & 11,60 & 0,89 & Teto \\
\hline SP0201 & 30,83 & 28,9 & 7 & 2 & 36 & 4,13 & 14,45 & 1,25 & Teto \\
\hline SP0301 & 27,01 & 42,46 & 7 & 3 & 45 & 6,07 & 14,15 & 1,06 & Teto \\
\hline SP0401 & 23,11 & 15,07 & 4 & 1 & 20 & 3,77 & 15,07 & 1,33 & Teto \\
\hline SP0501 & 25,06 & 23,88 & 5 & 2 & 38 & 4,78 & 11,94 & 1,59 & Teto \\
\hline SP0601 & 30,85 & 26,82 & 7 & 3 & 39 & 3,83 & 8,94 & 1,45 & Teto \\
\hline SP0701 & 29,92 & 17,12 & 6 & 2 & 34 & 2,85 & 8,56 & 1,99 & Teto \\
\hline SP0702 & 28,49 & 41,77 & 7 & 3 & 44 & 5,97 & 13,92 & 1,05 & Teto/Piso \\
\hline SP0801 & 25,51 & 18,97 & 6 & 3 & 32 & 3,16 & 6,32 & 1,69 & Teto \\
\hline SP0901a & 24,44 & 26,86 & 5 & 3 & 35 & 5,37 & 8,95 & 1,30 & Piso \\
\hline SP0901b & 26,62 & 17,8 & 3 & 2 & 25 & 5,93 & 8,90 & 1,40 & Piso \\
\hline SP1001 & 26,73 & 47,55 & 8 & 4 & 60 & 5,94 & 11,89 & 1,26 & Teto \\
\hline SP1002 & 34,23 & 38,95 & 7 & 3 & 44 & 5,56 & 12,98 & 1,13 & Teto \\
\hline
\end{tabular}




\subsubsection{Ramais e sub-ramais}

\section{Banheiros social e das suítes}

Tabela 6.24 - Indicadores de consumo e fatores potencialmente influenciadores: ramais e sub-ramais de água fria - banheiros das suítes e banheiro social

\begin{tabular}{|c|c|c|c|c|c|c|c|c|c|}
\hline Obra & Ambiente & $\begin{array}{l}\text { Área } \\
\left(\mathrm{m}^{2}\right)\end{array}$ & $\begin{array}{c}\text { Comprimento } \\
\text { (m) }\end{array}$ & $\begin{array}{l}\text { Número de } \\
\text { pontos de } \\
\text { consumo }\end{array}$ & $\begin{array}{l}\text { Número de } \\
\text { conexões }\end{array}$ & $\begin{array}{l}\text { Metros/ } \\
\text { pontos }\end{array}$ & Conex./metro & $\begin{array}{l}\text { Posição dos } \\
\text { ramais e sub- } \\
\text { ramais }\end{array}$ & $\begin{array}{l}\text { Pontos de } \\
\text { consumo em } \\
\text { uma única } \\
\text { parede? }\end{array}$ \\
\hline \multirow[t]{3}{*}{ SP0101 } & Banheiro social & 3,12 & 8,38 & 3 & 19 & 2,79 & 2,27 & Parede/Teto & Não \\
\hline & Banheiro suíte 1 & 4,90 & 9,16 & 5 & 22 & 1,83 & 2,40 & Parede/Teto & Não \\
\hline & Banheiro suíte 2 & 3,11 & 4,68 & 3 & 15 & 1,56 & 3,21 & Parede & Sim \\
\hline \multirow[t]{3}{*}{ SP0201 } & Banheiro suíte 1 & 3,78 & 7,80 & 5 & 22 & 1,56 & 2,82 & Parede & Não \\
\hline & Banheiro suíte 2 & 2,61 & 4,55 & 4 & 15 & 1,14 & 3,30 & Parede & Não \\
\hline & Banheiro suíte 3 & 2,60 & 5,10 & 4 & 17 & 1,28 & 3,33 & Parede & Não \\
\hline \multirow[t]{3}{*}{ SP0301 } & Banheiro suíte 1 & 6,58 & 14,86 & 6 & 27 & 2,48 & 1,82 & Parede/Teto & Não \\
\hline & Banheiro suíte 2 & 2,75 & 6,54 & 4 & 18 & 1,64 & 2,75 & Parede/Teto & Sim \\
\hline & Banheiro social & 3,03 & 6,54 & 4 & 15 & 1,64 & 2,29 & Parede/Teto & Não \\
\hline \multirow[t]{2}{*}{ SP0401 } & Banheiro suíte 1 & 2,91 & 6,21 & 4 & 13 & 1,55 & 2,09 & Parede/Teto & Sim \\
\hline & Banheiro social & 2,90 & 7,68 & 4 & 16 & 1,92 & 2,08 & Parede/Teto & Sim \\
\hline \multirow[t]{2}{*}{ SP0501 } & Banheiro suíte 1 & 2,77 & 5,35 & 4 & 17 & 1,34 & 3,18 & Parede & Não \\
\hline & Banheiro social & 2,43 & 3,79 & 4 & 16 & 0,95 & 4,22 & Parede & Sim \\
\hline
\end{tabular}


Tabela 6.24 - Indicadores de consumo de materiais e fatores potencialmente influenciadores: ramais e sub-ramais de água fria - banheiros das suítes e banheiro social - continuação

\begin{tabular}{|c|c|c|c|c|c|c|c|c|c|}
\hline Obra & Ambiente & $\begin{array}{l}\text { Área } \\
\left(m^{2}\right)\end{array}$ & $\begin{array}{l}\text { Comprimento } \\
(\mathrm{m})\end{array}$ & $\begin{array}{l}\text { Número de } \\
\text { pontos de } \\
\text { consumo }\end{array}$ & $\begin{array}{l}\text { Número de } \\
\text { conexões }\end{array}$ & $\begin{array}{l}\text { Metros/ } \\
\text { pontos }\end{array}$ & Conex./metro & $\begin{array}{l}\text { Posição dos } \\
\text { ramais e sub- } \\
\text { ramais }\end{array}$ & $\begin{array}{l}\text { Pontos de } \\
\text { consumo em } \\
\text { uma única } \\
\text { parede? }\end{array}$ \\
\hline \multirow[t]{3}{*}{ SP0601 } & Banheiro suíte 1 & 4,50 & 7,54 & 6 & 24 & 1,26 & 3,18 & Parede & Não \\
\hline & Banheiro suíte 2 & 2,53 & 6,30 & 4 & 18 & 1,58 & 2,86 & Parede & Sim \\
\hline & Banheiro social & 2,53 & 5,86 & 4 & 19 & 1,47 & 3,24 & Parede & Sim \\
\hline \multirow[b]{2}{*}{ SP0701 } & Banheiro social & 2,31 & 5,63 & 3 & 15 & 1,88 & 2,66 & Parede/Teto & Sim \\
\hline & Banheiro suíte 1 & 3,83 & 7,53 & 3 & 16 & 2,51 & 2,12 & Parede/Teto & Não \\
\hline \multirow[b]{3}{*}{ SP0702 } & Banheiro social & 3,19 & 5,93 & 3 & 14 & 1,98 & 2,36 & Parede/Teto & Sim \\
\hline & Banheiro suíte 1 & 4,01 & 6,93 & 3 & 19 & 2,31 & 2,74 & Parede/Teto & Sim \\
\hline & Banheiro suíte 2 & 2,5 & 4,85 & 3 & 17 & 1,62 & 3,51 & Parede/Teto & Sim \\
\hline \multirow[b]{2}{*}{ SP0801 } & Banheiro social & 2,76 & 4,75 & 3 & 17 & 1,58 & 3,58 & Parede & Sim \\
\hline & Banheiro suíte 1 & 2,76 & 4,75 & 3 & 17 & 1,58 & 3,58 & Parede & Sim \\
\hline \multirow[t]{2}{*}{ SP0901a } & Banheiro social & 2,49 & 6,46 & 4 & 18 & 1,62 & 2,79 & Parede/Teto & Não \\
\hline & Banheiro suíte 1 & 2,49 & 5,50 & 4 & 18 & 1,38 & 3,27 & Parede/Teto & Sim \\
\hline SP0901b & Banheiro social & 2,61 & 5,50 & 4 & 18 & 1,38 & 3,27 & Parede/Teto & Sim \\
\hline \multirow[t]{4}{*}{ SP1001 } & Banheiro suíte 1 & 7,62 & 8,69 & 7 & 24 & 1,24 & 2,76 & Parede & Não \\
\hline & Banheiro suíte 2 & 2,62 & 7,09 & 5 & 25 & 1,42 & 3,53 & Parede & Não \\
\hline & Banheiro suíte 3 & 2,77 & 7,00 & 5 & 24 & 1,40 & 3,43 & Parede & Não \\
\hline & Banheiro suíte 4 & 3,13 & 6,53 & 5 & 25 & 1,31 & 3,83 & Parede & Sim \\
\hline \multirow[t]{3}{*}{ SP1002 } & Banheiro social & 3,50 & 4,78 & 4 & 16 & 1,20 & 3,35 & Parede & Sim \\
\hline & Banheiro suíte 1 & 6,11 & 9,07 & 5 & 22 & 1,81 & 2,43 & Parede & Não \\
\hline & Banheiro suíte 2 & 2,84 & 6,15 & 4 & 17 & 1,54 & 2,76 & Parede & Não \\
\hline
\end{tabular}




\section{Banheiro de empregada}

Tabela 6.25 - Indicadores de consumo de materiais e fatores potencialmente influenciadores: ramais e sub-ramais de água fria - banheiro de empregada

\begin{tabular}{|c|c|c|c|c|c|c|c|c|}
\hline Obra & Área $\left(\mathrm{m}^{2}\right)$ & $\begin{array}{c}\text { Comprimento } \\
(\mathrm{m})\end{array}$ & $\begin{array}{l}\text { Número de } \\
\text { pontos de } \\
\text { consumo }\end{array}$ & $\begin{array}{l}\text { Número de } \\
\text { conexões }\end{array}$ & $\begin{array}{l}\text { Metros/ } \\
\text { pontos }\end{array}$ & Conex./metro & $\begin{array}{l}\text { Posição dos } \\
\text { ramais e sub- } \\
\text { ramais }\end{array}$ & $\begin{array}{l}\text { Pontos de } \\
\text { consumo em } \\
\text { uma única } \\
\text { parede? }\end{array}$ \\
\hline SP0101 & 2,18 & 4,43 & 3 & 13 & 1,48 & 2,93 & Parede & Sim \\
\hline SP0201 & 1,42 & 4,36 & 3 & 13 & 1,45 & 2,98 & Parede & Sim \\
\hline SP0301 & 1,78 & 7,36 & 3 & 14 & 2,45 & 1,90 & Parede/Teto & Não \\
\hline SP0501 & 1,35 & 3,69 & 2 & 11 & 1,85 & 2,98 & Parede & Sim \\
\hline SP0601 & 1,79 & 7,22 & 3 & 17 & 2,41 & 2,35 & Parede & Não \\
\hline SP0701 & 1,93 & 5,52 & 3 & 14 & 1,84 & 2,54 & Parede & Não \\
\hline SP0702 & 1,35 & 5,42 & 3 & 14 & 1,81 & 2,58 & Parede/Teto & Não \\
\hline SP0801 & 1,30 & 3,60 & 2 & 9 & 1,80 & 2,50 & Parede & Não \\
\hline SP0901a & 1,22 & 6,45 & 3 & 16 & 2,15 & 2,48 & Parede/Teto & Não \\
\hline SP1001 & 1,55 & 6,36 & 3 & 14 & 2,12 & 2,20 & Parede & Não \\
\hline SP1002 & 1,74 & 7,90 & 3 & 16 & 2,63 & 2,03 & Parede/Teto & Não \\
\hline
\end{tabular}




\section{Lavabo}

Tabela 6.26 - Indicadores de consumo de materiais e fatores potencialmente influenciadores: ramais e sub-ramais de água fria - lavabo

\begin{tabular}{|c|c|c|c|c|c|c|c|c|}
\hline Obra & Área $\left(\mathrm{m}^{2}\right)$ & $\begin{array}{c}\text { Comprimento } \\
(\mathrm{m})\end{array}$ & $\begin{array}{l}\text { Número de } \\
\text { pontos de } \\
\text { consumo }\end{array}$ & $\begin{array}{l}\text { Número de } \\
\text { conexões }\end{array}$ & $\begin{array}{l}\text { Metros/ } \\
\text { pontos }\end{array}$ & Conex./metro & $\begin{array}{l}\text { Posição dos } \\
\text { ramais e sub- } \\
\text { ramais }\end{array}$ & $\begin{array}{l}\text { Pontos de } \\
\text { consumo em } \\
\text { uma única } \\
\text { parede? }\end{array}$ \\
\hline SP0101 & 1,52 & 3,04 & 2 & 5 & 1,52 & 1,64 & Parede & Sim \\
\hline SP0201 & 1,71 & 3,98 & 2 & 9 & 1,99 & 2,26 & Parede & Não \\
\hline SP0301 & 1,87 & 5,48 & 2 & 11 & 2,74 & 2,01 & Parede/Teto & Sim \\
\hline SP0601 & 2,01 & 3,17 & 2 & 7 & 1,59 & 2,21 & Parede/Teto & Sim \\
\hline SP0701 & 1,84 & 4,34 & 2 & 9 & 2,17 & 2,07 & Parede & Não \\
\hline SP0702 & 1,69 & 4,00 & 2 & 13 & 2,00 & 3,25 & Parede/Teto & Sim \\
\hline SP0801 & 1,32 & 3,60 & 2 & 9 & 1,80 & 2,50 & Parede & Sim \\
\hline SP1001 & 1,84 & 4,20 & 3 & 11 & 1,40 & 2,62 & Parede & Não \\
\hline SP1002 & 2,19 & 7,55 & 2 & 11 & 3,78 & 1,46 & Parede/Teto & Não \\
\hline
\end{tabular}




\section{Área de serviço}

Tabela 6.27 - Indicadores de consumo de materiais e fatores potencialmente influenciadores: ramais e sub-ramais de água fria - área de serviço

\begin{tabular}{|c|c|c|c|c|c|c|c|c|}
\hline Obra & Área $\left(\mathrm{m}^{2}\right)$ & $\begin{array}{c}\text { Comprimento } \\
(\mathrm{m})\end{array}$ & $\begin{array}{l}\text { Número de } \\
\text { pontos de } \\
\text { consumo }\end{array}$ & $\begin{array}{l}\text { Número de } \\
\text { conexões }\end{array}$ & $\begin{array}{l}\text { Metros/ } \\
\text { pontos }\end{array}$ & Conex./metro & $\begin{array}{l}\text { Posição dos } \\
\text { ramais e sub- } \\
\text { ramais }\end{array}$ & $\begin{array}{l}\text { Pontos de } \\
\text { consumo em } \\
\text { uma única } \\
\text { parede? }\end{array}$ \\
\hline SP0101 & 6,26 & 3,61 & 2 & 8 & 1,81 & 2,22 & Parede & Sim \\
\hline SP0201 & 4,82 & 3,93 & 2 & 10 & 1,97 & 2,54 & Parede & Sim \\
\hline SP0301 & 6,79 & 3,04 & 3 & 9 & 1,01 & 2,96 & Parede & Sim \\
\hline SP0401 & 2,39 & 3,75 & 2 & 4 & 1,88 & 1,07 & Parede & Sim \\
\hline SP0501 & 3,81 & 1,84 & 2 & 7 & 0,92 & 3,80 & Parede & Sim \\
\hline SP0601 & 12,23 & 4,52 & 2 & 16 & 2,26 & 3,54 & Parede & Sim \\
\hline SP0701 & 7,02 & 2,00 & 2 & 4 & 1,00 & 2,00 & Parede & Não \\
\hline SP0702 & 4,99 & 1,81 & 2 & 5 & 0,91 & 2,76 & Parede/Teto & Sim \\
\hline SP0801 & 4,04 & 1,60 & 2 & 7 & 0,80 & 4,38 & Parede & Sim \\
\hline SP0901a & 3,96 & 1,39 & 1 & 4 & 1,39 & 2,88 & Parede/Teto & Sim \\
\hline SP0901b & 2,40 & 1,39 & 1 & 4 & 1,39 & 2,88 & Parede/Teto & Sim \\
\hline SP1001 & 7,60 & 3,68 & 3 & 11 & 1,23 & 2,99 & Parede & Sim \\
\hline SP1002 & 6,58 & 2,85 & 2 & 8 & 1,43 & 2,81 & Parede & Sim \\
\hline
\end{tabular}




\section{Cozinha}

Tabela 6.28 - Indicadores de consumo de materiais e fatores potencialmente influenciadores: ramais e sub-ramais de água fria - cozinha

\begin{tabular}{|c|c|c|c|c|c|c|c|c|}
\hline Obra & Área $\left(\mathrm{m}^{2}\right)$ & $\begin{array}{c}\text { Comprimento } \\
(\mathrm{m})\end{array}$ & $\begin{array}{l}\text { Número de } \\
\text { pontos de } \\
\text { consumo }\end{array}$ & $\begin{array}{l}\text { Número de } \\
\text { conexões }\end{array}$ & $\begin{array}{l}\text { Metros/ } \\
\text { pontos }\end{array}$ & Conex./metro & $\begin{array}{l}\text { Posição dos } \\
\text { ramais e sub- } \\
\text { ramais }\end{array}$ & $\begin{array}{l}\text { Pontos de } \\
\text { consumo em } \\
\text { uma única } \\
\text { parede? }\end{array}$ \\
\hline SP0101 & 12,35 & 5,94 & 4 & 12 & 1,49 & 2,02 & Parede & Não \\
\hline SP0201 & 13,82 & 5,92 & 3 & 10 & 1,97 & 1,69 & Parede & Sim \\
\hline SP0301 & 17,56 & 9,05 & 4 & 24 & 2,26 & 2,65 & Parede & Não \\
\hline SP0401 & 5,04 & 6,00 & 3 & 10 & 2,00 & 1,67 & Parede & Sim \\
\hline SP0501 & 6,91 & 4,64 & 3 & 11 & 1,55 & 2,37 & Parede & Sim \\
\hline SP0601 & 8,65 & 5,96 & 5 & 21 & 1,19 & 3,52 & Parede & Sim \\
\hline SP0701 & 7,51 & 8,47 & 4 & 15 & 2,12 & 1,77 & Parede & Não \\
\hline SP0702 & 12,97 & 2,90 & 3 & 6 & 0,97 & 2,07 & Parede/Teto & Sim \\
\hline SP0801 & 7,25 & 3,46 & 3 & 18 & 1,15 & 5,20 & Parede & Sim \\
\hline SP0901a & 4,94 & 0,60 & 1 & 2 & 0,60 & 3,33 & Parede/Teto & Sim \\
\hline SP0901b & 4,32 & 0,60 & 1 & 2 & 0,60 & 3,33 & Parede/Teto & Sim \\
\hline SP1001 & 12,08 & 3,40 & 5 & 10 & 0,68 & 2,94 & Parede & Sim \\
\hline SP1002 & 13,20 & 9,20 & 4 & 21 & 2,30 & 2,28 & Parede & Sim \\
\hline
\end{tabular}


Terraços

Tabela 6.29 - Indicadores de consumo de materiais e fatores potencialmente influenciadores: ramais e sub-ramais de água fria - terraços

\begin{tabular}{|c|c|c|c|c|c|c|c|}
\hline Obra & Ambiente & Área $\left.\mathbf{( m}^{2}\right)$ & Comprimento $(\mathbf{m})$ & $\begin{array}{c}\text { Número de pontos } \\
\text { de consumo }\end{array}$ & $\begin{array}{c}\text { Número de } \\
\text { conexões }\end{array}$ & $\begin{array}{c}\text { Metros/ } \\
\text { pontos }\end{array}$ & Conex./metro \\
\hline SP0101 & Sala de Estar & 17,65 & 1,04 & 1 & 5 & $\mathbf{0 , 9 6}$ & $\mathbf{4 , 8 1}$ \\
\hline SP0201 & Sala de Estar & 10,85 & 2,01 & 1 & 9 & $\mathbf{0 , 5 0}$ \\
\hline SP0301 & Sala de Estar & 10,89 & 0,20 & 1 & 1 & $\mathbf{4 , 4 8}$ \\
\hline SP0601 & Sala de Estar & 32,02 & 5,46 & 1 & 11 & $\mathbf{5 , 0 0}$ & $\mathbf{0 , 1 8}$ \\
\hline SP1001 & Sala de Jantar & 3,00 & 2,00 & 1 & 4 & $\mathbf{0 , 0 0}$ \\
\hline SP1002 & Sala de Estar & 17,60 & 1,50 & 1 & 5 & $\mathbf{0 , 5 0}$ & $\mathbf{0 , 6 7}$ \\
\hline
\end{tabular}


6.3.2 Sistema predial de suprimento de água quente

\subsubsection{Ramal de distribuição}

Tabela 6.30 - Indicadores de consumo e fatores potencialmente influenciadores: ramal de distribuição de água quente

\begin{tabular}{|c|c|c|c|c|c|c|c|c|c|c|}
\hline Obra & $\begin{array}{c}\text { \% de } \\
\text { áreas } \\
\text { molhávei } \\
\text { s }\end{array}$ & $\begin{array}{l}\text { Compr. } \\
\text { (metros) }\end{array}$ & $\begin{array}{c}\text { Núm. de } \\
\text { ambientes } \\
\text { atendidos }\end{array}$ & $\begin{array}{c}\text { Núm. de } \\
\text { conjuntos de } \\
\text { ambientes } \\
\text { molháveis }\end{array}$ & $\begin{array}{l}\text { Número de } \\
\text { conexões }\end{array}$ & $\begin{array}{l}\text { m/ambientes } \\
\text { atendidos }\end{array}$ & $\begin{array}{l}\text { m/conjunto } \\
\text { de ambientes }\end{array}$ & Conex./m & $\begin{array}{l}\text { Tubulação de } \\
\text { retorno (Sim, } \\
\text { Não)? }\end{array}$ & $\begin{array}{l}\text { Posição do } \\
\text { ramal de } \\
\text { distribuição }\end{array}$ \\
\hline SP0101 & 30,56 & 31,80 & 5 & 3 & 28 & 6,36 & 10,60 & 0,66 & Sim & Teto \\
\hline SP0201 & 30,83 & 26,11 & 4 & 2 & 17 & 6,53 & 13,06 & 0,65 & Não & Teto \\
\hline SP0301 & 27,01 & 30,68 & 4 & 3 & 21 & 7,67 & 10,23 & 0,68 & Não & Teto \\
\hline SP0401 & - & - & - & - & - & - & - & - & - & - \\
\hline SP0501 & 25,06 & 12,56 & 3 & 2 & 17 & 4,19 & 6,28 & 1,35 & Não & Teto \\
\hline SP0601 & 30,85 & 16,66 & 3 & 3 & 13 & 5,55 & 5,55 & 0,78 & Não & Teto \\
\hline SP0701 & 29,92 & 16,85 & 3 & 2 & 11 & 5,62 & 8,43 & 0,65 & Não & Teto \\
\hline SP0702 & 28,49 & 24,98 & 4 & 3 & 14 & 6,25 & 8,33 & 0,56 & Não & Teto/Piso \\
\hline SP0801 & 25,51 & 16,35 & 3 & 3 & 15 & 5,45 & 5,45 & 0,92 & Não & Teto \\
\hline SP0901a & 24,44 & 13,76 & 3 & 3 & 11 & 4,59 & 4,59 & 0,80 & Não & Piso \\
\hline SP0901b & 26,62 & 15,50 & 2 & 2 & 16 & 7,75 & 7,75 & 1,03 & Não & Piso \\
\hline SP1001 & 26,73 & 46,75 & 6 & 4 & 54 & 7,79 & 11,69 & 0,51 & Sim & Teto \\
\hline SP1002 & 34,23 & 25,75 & 4 & 3 & 70 & 6,44 & 8,58 & 0,78 & Sim & Teto \\
\hline
\end{tabular}




\subsubsection{Ramal de retorno}

Tabela 6.31 - Indicadores de consumo e fatores potencialmente influenciadores: ramal de retorno de água quente

\begin{tabular}{|c|c|c|c|c|c|c|c|c|c|}
\hline Obra & $\begin{array}{c}\text { \% de } \\
\text { áreas } \\
\text { molhávei } \\
\text { s }\end{array}$ & $\begin{array}{l}\text { Compr. } \\
\text { (metros) }\end{array}$ & $\begin{array}{l}\text { Núm. de } \\
\text { ambientes } \\
\text { atendidos }\end{array}$ & $\begin{array}{l}\text { Núm. de } \\
\text { conjuntos de } \\
\text { ambientes } \\
\text { molháveis }\end{array}$ & $\begin{array}{l}\text { Número de } \\
\text { conexões }\end{array}$ & $\begin{array}{l}\text { m/ambientes } \\
\text { atendidos }\end{array}$ & $\begin{array}{c}\text { m/conjunto } \\
\text { de ambientes }\end{array}$ & Conex./m & $\begin{array}{l}\text { Posição do ramal de } \\
\text { retorno }\end{array}$ \\
\hline SP0101 & 30,56 & 7,0 & 5 & 3 & 7 & 1,40 & 2,33 & 1,00 & Teto \\
\hline SP0201 & 30,83 & - & - & - & - & - & - & - & Teto \\
\hline SP0301 & 27,01 & - & - & - & - & - & - & - & Teto \\
\hline SP0401 & - & - & - & - & - & - & - & - & - \\
\hline SP0501 & 25,06 & - & - & - & - & - & - & - & Teto \\
\hline SP0601 & 30,85 & - & - & - & - & - & - & - & Teto \\
\hline SP0701 & 29,92 & - & - & - & - & - & - & - & Teto \\
\hline SP0702 & 28,49 & - & - & - & - & - & - & - & Teto/Piso \\
\hline SP0801 & 25,51 & - & - & - & - & - & - & - & Teto \\
\hline SP0901a & 24,44 & - & - & - & - & - & - & - & Piso \\
\hline SP0901b & 26,62 & - & - & - & - & - & - & - & Piso \\
\hline SP1001 & 26,73 & 30,3 & 6 & 4 & 30 & 5,04 & 7,56 & 0,99 & Teto \\
\hline SP1002 & 34,23 & 19,5 & 4 & 3 & 50 & 4,86 & 6,48 & 2,57 & Teto \\
\hline
\end{tabular}




\subsubsection{Ramais e sub-ramais}

\section{Banheiros social e das suítes}

Tabela 6.32 - Indicadores de consumo e fatores potencialmente influenciadores: ramais e sub-ramais de água quente - banheiros das suítes e banheiro social

\begin{tabular}{|c|c|c|c|c|c|c|c|c|c|}
\hline Obra & Ambiente & $\begin{array}{l}\text { Área } \\
\left(\mathrm{m}^{2}\right)\end{array}$ & $\begin{array}{c}\text { Comprimento } \\
(\mathrm{m})\end{array}$ & $\begin{array}{l}\text { Número de } \\
\text { pontos de } \\
\text { consumo }\end{array}$ & $\begin{array}{l}\text { Número de } \\
\text { conexões }\end{array}$ & $\begin{array}{l}\text { Metros/ } \\
\text { pontos }\end{array}$ & Conex./metro & $\begin{array}{l}\text { Posição dos } \\
\text { ramais e sub- } \\
\text { ramais }\end{array}$ & $\begin{array}{l}\text { Pontos de } \\
\text { consumo em } \\
\text { uma única } \\
\text { parede? }\end{array}$ \\
\hline \multirow[t]{3}{*}{ SP0101 } & Banheiro social & 3,12 & 8,71 & 2 & 16 & 4,36 & 1,84 & Parede/teto & Não \\
\hline & Banheiro suíte 1 & 4,90 & 9,98 & 4 & 26 & 2,50 & 2,61 & Parede/teto & Não \\
\hline & Banheiro suíte 2 & 3,11 & 4,73 & 2 & 14 & 2,37 & 2,96 & Parede & Sim \\
\hline \multirow[t]{3}{*}{ SP0201 } & Banheiro suíte 1 & 3,78 & 8,00 & 3 & 22 & 2,67 & 2,75 & Parede & Não \\
\hline & Banheiro suíte 2 & 2,61 & 4,58 & 2 & 13 & 2,29 & 2,84 & Parede & Não \\
\hline & Banheiro suíte 3 & 2,60 & 4,10 & 2 & 14 & 2,05 & 3,41 & Parede & Sim \\
\hline \multirow[t]{3}{*}{ SP0301 } & Banheiro social & 3,03 & 7,10 & 2 & 14 & 3,55 & 1,97 & Parede/teto & Sim \\
\hline & Banheiro suíte 1 & 6,58 & 14,64 & 5 & 28 & 2,93 & 1,91 & Parede/teto & Não \\
\hline & Banheiro suíte 2 & 2,75 & 6,72 & 2 & 14 & 3,36 & 2,08 & Parede/teto & Sim \\
\hline \multirow[t]{2}{*}{ SP0501 } & Banheiro social & 2,43 & 4,25 & 2 & 14 & 2,13 & 3,29 & Parede & Sim \\
\hline & Banheiro suíte 1 & 2,77 & 4,55 & 2 & 13 & 2,28 & 2,86 & Parede & Não \\
\hline \multirow[t]{3}{*}{ SP0601 } & Banheiro social & 2,53 & 5,96 & 2 & 16 & 2,98 & 2,68 & Parede & Sim \\
\hline & Banheiro suíte 1 & 4,50 & 8,54 & 5 & 27 & 1,71 & 3,16 & Parede & Não \\
\hline & Banheiro suíte 2 & 2,53 & 6,34 & 2 & 16 & 3,17 & 2,52 & Parede & Sim \\
\hline
\end{tabular}


Tabela 6.32 - Indicadores de consumo e fatores potencialmente influenciadores: ramais e sub-ramais de água quente - banheiros das suítes e banheiro social - continuação

\begin{tabular}{|c|c|c|c|c|c|c|c|c|c|}
\hline Obra & Ambiente & $\begin{array}{l}\text { Área } \\
\left(\mathrm{m}^{2}\right)\end{array}$ & $\begin{array}{c}\text { Comprimento } \\
(\mathrm{m})\end{array}$ & $\begin{array}{l}\text { Número de } \\
\text { pontos de } \\
\text { consumo }\end{array}$ & $\begin{array}{l}\text { Número de } \\
\text { conexões }\end{array}$ & $\begin{array}{l}\text { Metros/ } \\
\text { pontos }\end{array}$ & Conex./metro & $\begin{array}{l}\text { Posição dos } \\
\text { ramais e sub- } \\
\text { ramais }\end{array}$ & $\begin{array}{l}\text { Pontos de } \\
\text { consumo em } \\
\text { uma única } \\
\text { parede? }\end{array}$ \\
\hline \multirow[t]{2}{*}{ SP0701 } & Banheiro social & 2,31 & 5,63 & 2 & 13 & 2,82 & 2,31 & Parede/teto & Sim \\
\hline & Banheiro suíte 1 & 3,83 & 7,32 & 2 & 14 & 3,66 & 1,91 & Parede/teto & Não \\
\hline \multirow[t]{3}{*}{ SP0702 } & Banheiro social & 3,19 & 6,44 & 2 & 12 & 3,22 & 1,86 & Parede/teto & Sim \\
\hline & Banheiro suíte 1 & 4,01 & 6,79 & 2 & 16 & 3,40 & 2,36 & Parede/teto & Sim \\
\hline & Banheiro suíte 2 & 2,5 & 5,54 & 2 & 16 & 2,77 & 2,89 & Parede/teto & Sim \\
\hline \multirow[t]{2}{*}{ SP0801 } & Banheiro social & 2,76 & 5,06 & 2 & 18 & 2,53 & 3,56 & Parede & Sim \\
\hline & Banheiro suíte 1 & 2,76 & 5,06 & 2 & 18 & 2,53 & 3,56 & Parede & Sim \\
\hline \multirow[t]{2}{*}{ SP0901a } & Banheiro social & 2,49 & 8,64 & 2 & 16 & 4,32 & 1,85 & Parede/teto & Sim \\
\hline & Banheiro suíte 1 & 2,49 & 8,49 & 2 & 16 & 4,25 & 1,88 & Parede/teto & Sim \\
\hline SP0901b & Banheiro social & 2,61 & 8,49 & 2 & 16 & 4,25 & 1,88 & Parede/teto & Sim \\
\hline \multirow[t]{4}{*}{ SP1001 } & Banheiro suíte 1 & 7,62 & 9,04 & 5 & 25 & 1,81 & 2,77 & Parede & Não \\
\hline & Banheiro suíte 2 & 2,62 & 6,72 & 2 & 21 & 3,36 & 3,13 & Parede & Não \\
\hline & Banheiro suíte 3 & 2,77 & 5,76 & 2 & 19 & 2,88 & 3,30 & Parede & Sim \\
\hline & Banheiro suíte 4 & 3,13 & 7,22 & 2 & 22 & 3,61 & 3,05 & Parede & Sim \\
\hline \multirow[t]{3}{*}{ SP1002 } & Banheiro social & 3,50 & 5,08 & 2 & 14 & 2,54 & 2,76 & Parede & Não \\
\hline & Banheiro suíte 1 & 6,11 & 9,13 & 3 & 21 & 3,04 & 2,30 & Parede & Sim \\
\hline & Banheiro suíte 2 & 2,84 & 4,11 & 2 & 13 & 2,06 & 3,16 & Parede & Sim \\
\hline
\end{tabular}




\section{Banheiro de empregada e lavabo}

Tabela 6.33 - Indicadores de consumo de materiais e fatores potencialmente influenciadores: ramais e sub-ramais de água quente - banheiro de empregada e lavabo

\begin{tabular}{|c|c|c|c|c|c|c|c|c|}
\hline Obra & Ambiente & $\begin{array}{c}\text { Área } \\
\left(\mathbf{m}^{2}\right)\end{array}$ & $\begin{array}{c}\text { Comprimento } \\
(\mathbf{m})\end{array}$ & $\begin{array}{c}\text { Número de } \\
\text { pontos de } \\
\text { consumo }\end{array}$ & $\begin{array}{c}\text { Número de } \\
\text { conexões }\end{array}$ & $\begin{array}{c}\text { Metros/ } \\
\text { pontos }\end{array}$ & $\begin{array}{c}\text { Conex./metro } \\
\text { Posição dos } \\
\text { ramais e sub- } \\
\text { ramais } \\
\text { consumo em } \\
\text { parede? }\end{array}$ \\
\hline SP0101 & Bn. empregada & 2,18 & 2,70 & 1 & 9 & 2,70 & 3,33 & Parede \\
\hline SP1001 & Lavabo & 1,84 & 3,55 & 1 & 7 & 3,55 & 1,97 \\
\hline
\end{tabular}




\section{Cozinha}

Tabela 6.34 - Indicadores de consumo de materiais e fatores potencialmente influenciadores: ramais e sub-ramais de água quente - cozinha

\begin{tabular}{|c|c|c|c|c|c|c|c|c|}
\hline Obra & Área $\left(\mathrm{m}^{2}\right)$ & $\begin{array}{c}\text { Comprimento } \\
(\mathrm{m})\end{array}$ & $\begin{array}{l}\text { Número de } \\
\text { pontos de } \\
\text { consumo }\end{array}$ & $\begin{array}{l}\text { Número de } \\
\text { conexões }\end{array}$ & $\begin{array}{l}\text { Metros/ } \\
\text { pontos }\end{array}$ & Conex./metro & $\begin{array}{l}\text { Posição dos } \\
\text { ramais e sub- } \\
\text { ramais }\end{array}$ & $\begin{array}{l}\text { Pontos de } \\
\text { consumo em } \\
\text { uma única } \\
\text { parede? }\end{array}$ \\
\hline SP0101 & 12,35 & 3,55 & 1 & 7 & 3,55 & 1,97 & Parede & Sim \\
\hline SP0201 & 13,82 & 5,98 & 1 & 10 & 5,98 & 1,67 & Parede & Sim \\
\hline SP0301 & 17,56 & 4,20 & 1 & 8 & 4,20 & 1,90 & Parede & Sim \\
\hline SP0501 & 6,91 & 3,00 & 1 & 6 & 3,00 & 2,00 & Parede & Sim \\
\hline SP0701 & 7,51 & 4,17 & 1 & 8 & 4,17 & 1,92 & Parede/teto & Sim \\
\hline SP0702 & 12,97 & 0,84 & 1 & 1 & 0,84 & 1,19 & Parede/teto & Sim \\
\hline SP0801 & 7,25 & 2,90 & 1 & 7 & 2,90 & 2,41 & Parede & Sim \\
\hline SP0901a & 4,94 & 0,60 & 1 & 1 & 0,60 & 1,67 & Parede/teto & Sim \\
\hline SP0901b & 4,32 & 0,60 & 1 & 1 & 0,60 & 1,67 & Parede/teto & Sim \\
\hline SP1001 & 12,08 & 3,50 & 2 & 10 & 1,75 & 2,86 & Parede & Sim \\
\hline SP1002 & 13,20 & 3,80 & 1 & 7 & 3,80 & 1,84 & Parede & Sim \\
\hline
\end{tabular}




\subsubsection{Sistema predial de suprimento de gás}

\subsubsection{Ramal de distribuição}

Tabela 6.35 - Indicadores de consumo de materiais e fatores potencialmente influenciadores: ramal de distribuição de gás

\begin{tabular}{|c|c|c|c|c|}
\hline Obra & $\begin{array}{c}\text { Comprimento } \\
(\mathbf{m})\end{array}$ & $\begin{array}{c}\text { Número de } \\
\text { conexões }\end{array}$ & Conexões/metro & $\begin{array}{c}\text { Prumada específica } \\
\text { ou comum aos } \\
\text { apartamentos?) }\end{array}$ \\
\hline SP0101 & 2,50 & 9 & 3,60 & Específica \\
\hline SP0201 & 2,94 & 8 & 2,72 & Específica \\
\hline SP0301 & 3,52 & 12 & 3,41 & Específica \\
\hline SP0401 & 6,20 & 9 & 1,45 & Comum \\
\hline SP0501 & 0,77 & 7 & 9,09 & Específica \\
\hline SP0601 & 1,18 & 10 & 8,47 & Específica \\
\hline SP0701 & 1,40 & 5 & 3,57 & Comum \\
\hline SP0702 & 11,22 & 8 & 0,71 & Específica \\
\hline SP0801 & 2,12 & 10 & 4,72 & Específica \\
\hline SP0901a & 1,29 & 4 & 3,10 & Específica \\
\hline SP0901b & 1,70 & 11 & 6,47 & Específica \\
\hline SP1001 & 0,60 & 7 & 11,67 & Específica \\
\hline SP1002 & 1,32 & 10 & 7,58 & \\
\hline
\end{tabular}




\subsubsection{Ramais e sub-ramais}

\section{Área de serviço}

Tabela 6.36 - Indicadores de consumo de materiais: ramais e sub-ramais de gás - área de serviço

\begin{tabular}{|c|c|c|c|c|c|c|}
\hline Obra & Área $\left(\mathrm{m}^{2}\right)$ & Comprimento (m) & $\begin{array}{l}\text { Número de pontos de } \\
\text { consumo }\end{array}$ & Número de conexões & $\begin{array}{l}\text { Metros/ } \\
\text { pontos }\end{array}$ & Conex./metro \\
\hline SP0101 & 6,26 & 2,88 & 1 & 3 & 2,88 & 1,04 \\
\hline SP0201 & 4,82 & 8,60 & 1 & 3 & 8,60 & 0,35 \\
\hline SP0301 & 6,79 & 3,48 & 1 & 7 & 3,48 & 2,01 \\
\hline SP0501 & 3,81 & 1,88 & 1 & 4 & 1,88 & 2,13 \\
\hline SP0601 & 12,23 & 1,80 & 1 & 5 & 1,80 & 2,78 \\
\hline SP0701 & 7,02 & 3,70 & 1 & 2 & 3,70 & 0,54 \\
\hline SP0702 & 4,99 & 5,44 & 1 & 4 & 5,44 & 0,74 \\
\hline SP0801 & 4,04 & 0,50 & 1 & 6 & 0,50 & 12,00 \\
\hline SP0901a & 3,96 & 4,72 & 1 & 3 & 4,72 & 0,64 \\
\hline SP0901b & 2,40 & 1,24 & 1 & 5 & 1,24 & 4,03 \\
\hline SP1001 & 7,60 & 7,38 & 1 & 7 & 7,38 & 0,95 \\
\hline SP1002 & 6,58 & 2,31 & 1 & 11 & 2,31 & 4,76 \\
\hline
\end{tabular}




\section{Cozinha}

Tabela 6.37 - Indicadores de consumo de materiais: ramais e sub-ramais de gás - cozinha

\begin{tabular}{|c|c|c|c|c|c|c|}
\hline Obra & Área $\left(\mathrm{m}^{2}\right)$ & Comprimento (m) & $\begin{array}{l}\text { Número de pontos de } \\
\text { consumo }\end{array}$ & Número de conexões & $\begin{array}{l}\text { Metros/ } \\
\text { pontos }\end{array}$ & Conex./metro \\
\hline SP0101 & 12,35 & 3,39 & 1 & 3 & 3,39 & 0,88 \\
\hline SP0201 & 13,82 & 2,14 & 1 & 3 & 2,14 & 1,40 \\
\hline SP0301 & 17,56 & 5,76 & 1 & 7 & 5,76 & 1,22 \\
\hline SP0401 & 5,04 & 3,15 & 1 & 3 & 3,15 & 0,95 \\
\hline SP0501 & 6,91 & 2,25 & 1 & 5 & 2,25 & 2,22 \\
\hline SP0601 & 8,65 & 3,24 & 1 & 5 & 3,24 & 1,54 \\
\hline SP0701 & 7,51 & 1,14 & 1 & 2 & 1,14 & 1,75 \\
\hline SP0702 & 12,97 & 0,78 & 1 & 3 & 0,78 & 3,85 \\
\hline SP0801 & 7,25 & 0,78 & 1 & 2 & 0,78 & 2,56 \\
\hline SP0901a & 4,94 & 3,03 & 1 & 5 & 3,03 & 1,65 \\
\hline SP0901b & 4,32 & 1,90 & 1 & 3 & 1,90 & 1,58 \\
\hline SP1001 & 12,08 & 3,75 & 1 & 7 & 3,75 & 1,87 \\
\hline SP1002 & 13,20 & 1,90 & 1 & 3 & 1,90 & 1,58 \\
\hline
\end{tabular}




\subsubsection{Sistema predial de coleta de esgoto sanitário - ramais}

\section{Banheiros social e das suítes}

Tabela 6.38 - Indicadores de consumo de materiais: ramais de esgoto e de ventilação - banheiros das suítes e banheiro social

\begin{tabular}{|c|c|c|c|c|c|c|c|}
\hline Obra & Ambiente & Área $\left(\mathrm{m}^{2}\right)$ & Comprimento (m) & $\begin{array}{l}\text { Número de pontos } \\
\text { de captação }\end{array}$ & $\begin{array}{l}\text { Número de } \\
\text { conexões }\end{array}$ & $\begin{array}{l}\text { Metros/ } \\
\text { pontos }\end{array}$ & Conex./metro \\
\hline \multirow[t]{3}{*}{ SP0101 } & Banheiro social & 3,12 & 3,84 & 5 & 10 & 0,77 & 2,60 \\
\hline & Banheiro suíte 1 & 4,90 & 9,01 & 6 & 18 & 1,50 & 2,00 \\
\hline & Banheiro suíte 2 & 3,11 & 5,08 & 4 & 12 & 1,27 & 2,36 \\
\hline \multirow[t]{3}{*}{ SP0201 } & Banheiro suíte 1 & 3,78 & 6,45 & 6 & 18 & 1,08 & 2,79 \\
\hline & Banheiro suíte 2 & 2,61 & 4,59 & 3 & 13 & 1,53 & 2,83 \\
\hline & Banheiro suíte 3 & 2,60 & 4,91 & 3 & 10 & 1,64 & 2,04 \\
\hline \multirow[t]{3}{*}{ SP0301 } & Banheiro suíte 1 & 3,03 & 5,68 & 4 & 11 & 1,42 & 1,94 \\
\hline & Banheiro suíte 2 & 6,58 & 13,82 & 8 & 25 & 1,73 & 1,81 \\
\hline & Banheiro social & 2,75 & 6,44 & 4 & 12 & 1,61 & 1,86 \\
\hline \multirow[t]{2}{*}{ SP0401 } & Banheiro suíte 1 & 2,90 & 3,4 & 4 & 17 & 0,85 & 5,00 \\
\hline & Banheiro social & 2,91 & 5,08 & 4 & 20 & 1,27 & 3,94 \\
\hline \multirow[t]{2}{*}{ SP0501 } & Banheiro suíte 1 & 2,43 & 3,48 & 4 & 13 & 0,87 & 3,74 \\
\hline & Banheiro social & 2,77 & 3,28 & 4 & 11 & 0,82 & 3,35 \\
\hline
\end{tabular}


Tabela 6.38 - Indicadores de consumo de materiais: ramais de esgoto e de ventilação - banheiros das suítes e banheiro social - continuação

\begin{tabular}{|c|c|c|c|c|c|c|c|}
\hline Obra & Ambiente & Área $\left(\mathrm{m}^{2}\right)$ & Comprimento (m) & $\begin{array}{l}\text { Número de pontos } \\
\text { de captação }\end{array}$ & $\begin{array}{l}\text { Número de } \\
\text { conexões }\end{array}$ & $\begin{array}{l}\text { Metros/ } \\
\text { pontos }\end{array}$ & Conex./metro \\
\hline \multirow[t]{3}{*}{ SP0601 } & Banheiro suíte 1 & 2,53 & 3,81 & 4 & 16 & 0,95 & 4,20 \\
\hline & Banheiro suíte 2 & 4,50 & 6,48 & 6 & 23 & 1,08 & 3,55 \\
\hline & Banheiro social & 2,53 & 3,60 & 4 & 16 & 0,90 & 4,44 \\
\hline \multirow[t]{2}{*}{ SP0701 } & Banheiro social & 2,31 & 2,44 & 4 & 9 & 0,61 & 3,69 \\
\hline & Banheiro suíte 1 & 3,83 & 4,86 & 4 & 13 & 1,22 & 2,67 \\
\hline \multirow[t]{3}{*}{ SP0702 } & Banheiro social & 3,19 & 4,34 & 3 & 12 & 1,45 & 2,76 \\
\hline & Banheiro suíte 1 & 4,01 & 4,86 & 3 & 12 & 1,62 & 2,47 \\
\hline & Banheiro suíte 2 & 2,5 & 3,98 & 3 & 12 & 1,33 & 3,02 \\
\hline \multirow[t]{2}{*}{ SP0801 } & Banheiro social & 2,76 & 2,52 & 4 & 12 & 0,63 & 4,76 \\
\hline & Banheiro suíte 1 & 2,76 & 2,52 & 4 & 12 & 0,63 & 4,76 \\
\hline \multirow[t]{2}{*}{ SP0901a } & Banheiro social & 2,49 & 3,3 & 4 & 10 & 0,83 & 3,03 \\
\hline & Banheiro suíte 1 & 2,49 & 2,54 & 4 & 13 & 0,64 & 5,12 \\
\hline SP0901b & Banheiro social & 2,61 & 2,54 & 4 & 13 & 0,64 & 5,12 \\
\hline \multirow[t]{4}{*}{ SP1001 } & Banheiro suíte 1 & 7,62 & 10,48 & 7 & 29 & 1,50 & 2,77 \\
\hline & Banheiro suíte 2 & 2,62 & 3,20 & 4 & 18 & 0,80 & 5,63 \\
\hline & Banheiro suíte 3 & 2,77 & 5,81 & 4 & 12 & 1,45 & 2,07 \\
\hline & Banheiro suíte 4 & 3,13 & 3,62 & 4 & 15 & 0,91 & 4,14 \\
\hline \multirow[t]{3}{*}{ SP1002 } & Banheiro social & 3,50 & 2,62 & 4 & 8 & 0,66 & 3,05 \\
\hline & Banheiro suíte 1 & 6,11 & 6,34 & 5 & 8 & 1,27 & 1,26 \\
\hline & Banheiro suíte 2 & 2,84 & 4,40 & 4 & 11 & 1,10 & 2,50 \\
\hline
\end{tabular}




\section{Banheiro de empregada}

Tabela 6.39 - Indicadores de consumo de materiais: ramais de esgoto e de ventilação - banheiro de empregada

\begin{tabular}{|c|c|c|c|c|c|c|}
\hline Obra & Área $\left(\mathrm{m}^{2}\right)$ & Comprimento (m) & $\begin{array}{l}\text { Número de pontos de } \\
\text { consumo }\end{array}$ & Número de conexões & $\begin{array}{l}\text { Metros/ } \\
\text { pontos }\end{array}$ & Conex./metro \\
\hline SP0101 & 2,18 & 3,77 & 3 & 10 & 1,26 & 2,65 \\
\hline SP0201 & 1,42 & 5,25 & 3 & 10 & 1,75 & 1,90 \\
\hline SP0301 & 1,78 & 4,28 & 3 & 10 & 1,43 & 2,34 \\
\hline SP0501 & 1,35 & 0,36 & 2 & 6 & 0,18 & 16,67 \\
\hline SP0601 & 1,79 & 4,24 & 4 & 15 & 1,06 & 3,54 \\
\hline SP0701 & 1,93 & 2,48 & 3 & 12 & 0,83 & 4,84 \\
\hline SP0702 & 1,35 & 3,38 & 3 & 14 & 1,13 & 4,14 \\
\hline SP0801 & 1,30 & 1,34 & 3 & 7 & 0,45 & 5,22 \\
\hline SP0901a & 1,22 & 2,51 & 3 & 11 & 0,84 & 4,38 \\
\hline SP1001 & 1,55 & 3,4 & 3 & 13 & 1,13 & 3,82 \\
\hline SP1002 & 1,74 & 4,72 & 4 & 15 & 1,18 & 3,18 \\
\hline
\end{tabular}




\section{Lavabo}

Tabela 6.40 - Indicadores de consumo de materiais: ramais de esgoto e de ventilação - lavabo

\begin{tabular}{|c|c|c|c|c|c|c|}
\hline Obra & Área $\left(\mathrm{m}^{2}\right)$ & Comprimento $(\mathrm{m})$ & $\begin{array}{l}\text { Número de pontos de } \\
\text { consumo }\end{array}$ & Número de conexões & $\begin{array}{l}\text { Metros/ } \\
\text { pontos }\end{array}$ & Conex./metro \\
\hline SP0101 & 1,52 & 3,05 & 3 & 8 & 1,02 & 2,62 \\
\hline SP0201 & 1,71 & 5,48 & 3 & 10 & 1,83 & 1,82 \\
\hline SP0601 & 2,01 & 1,80 & 3 & 11 & 0,60 & 6,11 \\
\hline SP0701 & 1,84 & 1,76 & 3 & 9 & 0,59 & 5,11 \\
\hline SP1001 & 1,84 & 2,24 & 3 & 12 & 0,75 & 5,36 \\
\hline SP1002 & 2,19 & 2,90 & 3 & 6 & 0,97 & 2,07 \\
\hline
\end{tabular}




\section{Cozinha}

Tabela 6.41 - Indicadores de consumo de materiais: ramais de esgoto e de ventilação - cozinha

\begin{tabular}{|c|c|c|c|c|c|c|}
\hline Obra & Área $\left(\mathrm{m}^{2}\right)$ & Comprimento (m) & $\begin{array}{l}\text { Número de pontos de } \\
\text { consumo }\end{array}$ & Número de conexões & $\begin{array}{l}\text { Metros/ } \\
\text { pontos }\end{array}$ & Conex./metro \\
\hline SP0101 & 12,35 & 3,39 & 3 & 10 & 1,13 & 2,95 \\
\hline SP0201 & 13,82 & 2,14 & 3 & 7 & 0,71 & 3,27 \\
\hline SP0301 & 17,56 & 5,76 & 5 & 11 & 1,15 & 1,91 \\
\hline SP0401 & 5,04 & 3,15 & 2 & 6 & 1,58 & 1,90 \\
\hline SP0501 & 6,91 & 2,25 & 2 & 13 & 1,13 & 5,78 \\
\hline SP0601 & 8,65 & 3,24 & 3 & 7 & 1,08 & 2,16 \\
\hline SP0701 & 7,51 & 1,14 & 2 & 7 & 0,57 & 6,14 \\
\hline SP0702 & 12,97 & 0,78 & 2 & 7 & 0,39 & 8,97 \\
\hline SP0801 & 7,25 & 0,78 & 2 & 5 & 0,39 & 6,41 \\
\hline SP0901a & 4,94 & 3,03 & 1 & 5 & 3,03 & 1,65 \\
\hline SP0901b & 4,32 & 1,90 & 2 & 3 & 0,95 & 1,58 \\
\hline SP1001 & 12,08 & 3,75 & 3 & 8 & 1,25 & 2,13 \\
\hline SP1002 & 13,20 & 1,9 & 3 & 10 & 0,63 & 5,26 \\
\hline
\end{tabular}




\section{Área de serviço}

Tabela 6.42 - Indicadores de consumo de materiais: ramais de esgoto e de ventilação - área de serviço

\begin{tabular}{|c|c|c|c|c|c|c|}
\hline Obra & Área $\left(\mathrm{m}^{2}\right)$ & Comprimento (m) & $\begin{array}{l}\text { Número de pontos de } \\
\text { consumo }\end{array}$ & Número de conexões & $\begin{array}{l}\text { Metros/ } \\
\text { pontos }\end{array}$ & Conex./metro \\
\hline SP0101 & 6,26 & 2,88 & 3 & 9 & 0,96 & 3,13 \\
\hline SP0201 & 4,82 & 8,60 & 3 & 13 & 2,87 & 1,51 \\
\hline SP0301 & 6,79 & 3,48 & 4 & 16 & 0,87 & 4,60 \\
\hline SP0401 & 2,39 & 1,60 & 3 & 4 & 0,53 & 2,50 \\
\hline SP0501 & 3,81 & 1,88 & 3 & 12 & 0,63 & 6,38 \\
\hline SP0702 & 4,99 & 5,44 & 3 & 9 & 1,81 & 1,65 \\
\hline SP0801 & 4,04 & 0,50 & 3 & 5 & 0,17 & 10,00 \\
\hline SP0901a & 3,96 & 4,72 & 2 & 9 & 2,36 & 1,91 \\
\hline SP0901b & 2,40 & 1,24 & 2 & 6 & 0,62 & 4,84 \\
\hline SP1001 & 7,60 & 7,38 & 4 & 11 & 1,85 & 1,49 \\
\hline
\end{tabular}


Terraço

Tabela 6.43 - Indicadores de consumo de materiais: ramais de esgoto e de ventilação - terraço da sala de estar

\begin{tabular}{|c|c|c|c|c|c|c|}
\hline Obra & Área $\left(\mathbf{m}^{2}\right)$ & Comprimento $(\mathbf{m})$ & $\begin{array}{c}\text { Número de pontos de } \\
\text { consumo }\end{array}$ & Número de conexões & $\begin{array}{l}\text { Metros/ } \\
\text { pontos }\end{array}$ & $\begin{array}{c}\text { Conex./metro } \\
\mathbf{S P 0 2 0 1}\end{array}$ \\
\hline SP0601 & 32,85 & 1,52 & 1 & 3 & $\mathbf{1 , 5 2}$ & $\mathbf{1 , 9 7}$ \\
\hline SP1002 & 17,60 & 1,46 & 1 & 3 & $\mathbf{1 , 4 6}$ & $\mathbf{2 , 0 5}$ \\
\hline
\end{tabular}


6.3.5 Sistema predial de coleta de águas pluviais - ramais

Tabela 6.44 - Indicadores de consumo de materiais: ramais de águas pluviais

\begin{tabular}{|c|c|c|c|c|c|c|c|}
\hline Obra & Ambiente & Área $\left(\mathrm{m}^{2}\right)$ & Comprimento (m) & $\begin{array}{l}\text { Número de pontos } \\
\text { de captação }\end{array}$ & $\begin{array}{l}\text { Número de } \\
\text { conexões }\end{array}$ & $\begin{array}{l}\text { Metros/ } \\
\text { pontos }\end{array}$ & Conex./metro \\
\hline \multirow[t]{2}{*}{ SP0101 } & Terraço Suíte 1 & 2,04 & 0,42 & 1 & 1 & 0,42 & 2,38 \\
\hline & Terraço Sala de Estar & 17,65 & 5,83 & 2 & 3 & 2,92 & 0,51 \\
\hline SP0201 & Terraço Sala de Estar & 10,85 & 4,60 & 2 & 5 & 2,30 & 1,09 \\
\hline \multirow[t]{3}{*}{ SP0301 } & Terraço Suíte 1 & 1,05 & 0,26 & 1 & 1 & 0,26 & 3,85 \\
\hline & Terraço Sala de Estar & 10,89 & 5,20 & 2 & 3 & 2,60 & 0,58 \\
\hline & Terraço Área de Serviço & 1,87 & 0,52 & 1 & 1 & 0,52 & 1,92 \\
\hline SP0401 & Terraço Sala de Estar & 3,86 & 0,08 & 1 & 1 & 0,08 & 12,50 \\
\hline SP0501 & Terraço Sala de Estar & 3,33 & 0,10 & 1 & 4 & 0,10 & 40,00 \\
\hline \multirow[t]{3}{*}{ SP0601 } & Terraço Suíte 1 & 2,41 & 0,18 & 1 & 1 & 0,18 & 5,56 \\
\hline & Terraço Sala de Estar & 32,02 & 0,24 & 2 & 2 & 0,12 & 8,33 \\
\hline & Terraço Área de Serviço & 1,07 & 0,14 & 1 & 1 & 0,14 & 7,14 \\
\hline \multirow[t]{2}{*}{ SP0701 } & Terraço Sala de Estar & 2,83 & 0,30 & 1 & 1 & 0,30 & 3,33 \\
\hline & Terraço Sala de Jantar & 0,45 & 0,30 & 1 & 1 & 0,30 & 3,33 \\
\hline SP0702 & Terraço Sala de Estar & 5,21 & 0,25 & 1 & 1 & 0,25 & 4,00 \\
\hline SP0801 & Terraço Sala de Estar & 4,05 & 0,20 & 1 & 1 & 0,20 & 5,00 \\
\hline SP0901a & Terraço Sala de Estar & 4,03 & 0,20 & 1 & 1 & 0,20 & 5,00 \\
\hline SP0901b & Terraço Sala de Estar & 2,81 & 0,20 & 1 & 1 & 0,20 & 5,00 \\
\hline
\end{tabular}


Tabela 6.44 - Indicadores de consumo de materiais: ramais de águas pluviais - continuação

\begin{tabular}{|c|c|c|c|c|c|c|c|}
\hline Obra & Ambiente & Área $\left(\mathrm{m}^{2}\right)$ & Comprimento (m) & $\begin{array}{l}\text { Número de pontos } \\
\text { de captação }\end{array}$ & $\begin{array}{l}\text { Número de } \\
\text { conexões }\end{array}$ & $\begin{array}{l}\text { Metros/ } \\
\text { pontos }\end{array}$ & Conex./metro \\
\hline \multirow[t]{3}{*}{ SP1001 } & Terraço Sala de Estar & 13,99 & 0,20 & 1 & 2 & 0,20 & 10,00 \\
\hline & Terraço Sala de Jantar & 3,00 & 1,00 & 1 & 1 & 1,00 & 1,00 \\
\hline & Terraço Suíte 1 & 0,75 & 0,30 & 1 & 2 & 0,30 & 6,67 \\
\hline \multirow[t]{2}{*}{ SP1002 } & Terraço Suíte 1 & 1,10 & 0,26 & 1 & 1 & 0,26 & 3,85 \\
\hline & Terraço Sala de Estar & 17,60 & 0,26 & 1 & 1 & 0,26 & 3,85 \\
\hline
\end{tabular}




\subsection{Estatísticas gerais}

Para cada tipo de sistema predial, a seguir, são apresentadas as estatísticas (valores mínimo, mediano e máximo) relacionadas aos indicadores de consumo apresentados neste capítulo para o conjunto de obras analisadas.

\subsubsection{Metros de tubulação e número de conexões por área de apartamento-tipo}

\subsubsection{Sistema predial de suprimento de água fria}

Tabela 6.45 - Estatísticas gerais (por área): sistema predial de suprimento de água fria

\begin{tabular}{|c|c|c|c|c|c|c|c|}
\hline \multirow[t]{2}{*}{ Subsistema } & \multicolumn{3}{|c|}{$\mathrm{m} / \mathrm{m}^{2} \times 10^{-3}$} & \multicolumn{3}{|c|}{ Conexões $/ \mathrm{m}^{2} \times 10^{-3}$} & \multirow{2}{*}{$\begin{array}{c}\text { Número } \\
\text { de } \\
\text { casos }\end{array}$} \\
\hline & Mínimo & Mediana & Máximo & Mínimo & Mediana & Máximo & \\
\hline Prumadas & 38 & 56 & 98 & 14 & 21 & 34 & 13 \\
\hline Ramal de distribuição & 129 & 235 & 390 & 173 & 282 & 549 & 13 \\
\hline Ramais e sub-ramais & 164 & 253 & 362 & 527 & 699 & 914 & 13 \\
\hline Geral & 399 & 574 & 705 & 747 & 1065 & 1276 & 13 \\
\hline
\end{tabular}

\subsubsection{Sistema predial de suprimento de água quente}

Tabela 6.46 - Estatísticas gerais (por área): sistema predial de suprimento de água quente

\begin{tabular}{|c|c|c|c|c|c|c|c|}
\hline \multirow[t]{2}{*}{ Subsistema } & \multicolumn{3}{|c|}{$\mathrm{m} / \mathrm{m}^{2} \times 10^{-3}$} & \multicolumn{3}{|c|}{ Conexões $/ \mathrm{m}^{2} \times 10^{-3}$} & \multirow{2}{*}{$\begin{array}{c}\text { Número } \\
\text { de } \\
\text { casos }\end{array}$} \\
\hline & Mínimo & Mediana & Máximo & Mínimo & Mediana & Máximo & \\
\hline Prumadas & 67 & 67 & 67 & 24 & 24 & 24 & 1 \\
\hline Ramal de distribuição & 74 & 186 & 362 & 58 & 151 & 423 & 12 \\
\hline Ramais e sub-ramais & 92 & 165 & 226 & 266 & 389 & 488 & 12 \\
\hline Geral & 166 & 357 & 539 & 324 & 582 & 754 & 12 \\
\hline
\end{tabular}




\subsubsection{Sistema predial de suprimento de gás}

Tabela 6.47 - Estatísticas gerais (por área): sistema predial de suprimento de gás

\begin{tabular}{|c|c|c|c|c|c|c|c|}
\hline \multirow[t]{2}{*}{ Subsistema } & \multicolumn{3}{|c|}{$\mathrm{m} / \mathrm{m}^{2} \times 10^{-3}$} & \multicolumn{3}{|c|}{ Conexões $/ \mathrm{m}^{2} \times 10^{-3}$} & \multirow{2}{*}{$\begin{array}{c}\text { Número } \\
\text { de } \\
\text { casos }\end{array}$} \\
\hline & Mínimo & Mediana & Máximo & Mínimo & Mediana & Máximo & \\
\hline Prumadas & 10 & 18 & 65 & 3 & 6 & 22 & 13 \\
\hline Ramal de distribuição & 3 & 16 & 89 & 33 & 60 & 241 & 13 \\
\hline Ramais e sub-ramais & 5 & 31 & 109 & 34 & 66 & 176 & 13 \\
\hline Geral & 48 & 75 & 211 & 92 & 135 & 439 & 13 \\
\hline
\end{tabular}

\subsubsection{Sistema predial de prevenção e combate a incêndios}

Tabela 6.48 - Estatísticas gerais (por área): sistema predial prevenção e combate a incêndios

\begin{tabular}{|c|c|c|c|c|c|c|c|}
\hline \multirow[t]{2}{*}{ Subsistema } & \multicolumn{3}{|c|}{$\mathrm{m} / \mathrm{m}^{2} \times 10^{-3}$} & \multicolumn{3}{|c|}{ Conexões $/ \mathrm{m}^{2} \times 10^{-3}$} & \multirow{2}{*}{$\begin{array}{c}\text { Número } \\
\text { de } \\
\text { casos }\end{array}$} \\
\hline & Mínimo & Mediana & Máximo & Mínimo & Mediana & Máximo & \\
\hline Prumadas & 8 & 11 & 22 & 3 & 4 & 7 & 13 \\
\hline Geral & 8 & 11 & 22 & 3 & 4 & 7 & 13 \\
\hline
\end{tabular}

\subsubsection{Sistema predial de coleta de esgoto sanitário}

Tabela 6.49 - Estatísticas gerais (por área): sistema predial de esgoto sanitário

\begin{tabular}{|c|c|c|c|c|c|c|c|}
\hline \multirow{2}{*}{ Subsistema } & \multicolumn{3}{|c|}{$\mathbf{m} / \mathbf{m}^{\mathbf{2}} \times \mathbf{1 0}^{-3}$} & \multicolumn{3}{c|}{ Conexões $/ \mathbf{m}^{\mathbf{2}} \mathbf{x} \mathbf{1 0}^{-3}$} & $\begin{array}{c}\text { Número } \\
\text { de } \\
\text { casos }\end{array}$ \\
\cline { 2 - 8 } & Mínimo & Mediana & Máximo & Mínimo & Mediana & Máximo & 13 \\
\hline Tubos de queda & 98 & 133 & 227 & 44 & 123 & 211 & 13 \\
\hline Colunas de ventilação & 54 & 92 & 144 & 27 & 51 & 124 & 13 \\
\hline Ramais & 97 & 180 & 289 & 409 & 553 & 669 & 13 \\
\hline Geral & $\mathbf{2 8 7}$ & $\mathbf{4 1 5}$ & $\mathbf{5 4 7}$ & $\mathbf{5 3 1}$ & $\mathbf{7 0 6}$ & $\mathbf{9 2 9}$ & $\mathbf{1 3}$ \\
\hline
\end{tabular}




\subsubsection{Sistema predial de coleta de águas pluviais}

Tabela 6.50 - Estatísticas gerais (por área): sistema predial de escoamento de águas pluviais

\begin{tabular}{|c|c|c|c|c|c|c|c|}
\hline \multirow[t]{2}{*}{ Subsistema } & \multicolumn{3}{|c|}{$\mathrm{m} / \mathrm{m}^{2} \times 10^{-3}$} & \multicolumn{3}{|c|}{ Conexões $/ \mathrm{m}^{2} \times 10^{-3}$} & \multirow{2}{*}{$\begin{array}{c}\text { Número } \\
\text { de } \\
\text { casos }\end{array}$} \\
\hline & Mínimo & Mediana & Máximo & Mínimo & Mediana & Máximo & \\
\hline Tubos de queda & 50 & 83 & 150 & 22 & 36 & 60 & 13 \\
\hline Ramais & 1 & 4 & 36 & 8 & 22 & 49 & 13 \\
\hline Geral & 51 & 102 & 156 & 44 & 53 & 97 & 13 \\
\hline
\end{tabular}

6.4.2 Metros de tubulação por ponto de consumo/captação e número de conexões por metro de tubulação

\subsubsection{Sistema predial de suprimento de água fria}

Tabela 6.51 - Estatísticas gerais (m/ponto; m/ambiente; conexões/m): sistema predial de suprimento de água fria

\begin{tabular}{|c|c|c|c|c|c|c|c|c|}
\hline \multicolumn{2}{|r|}{ Partes } & \multicolumn{3}{|c|}{ m/ambiente } & \multicolumn{3}{|c|}{ Conexões/m } & \multirow{2}{*}{$\begin{array}{c}\text { Número } \\
\text { de } \\
\text { casos }\end{array}$} \\
\hline & & Mínimo & $\begin{array}{c}\text { Median } \\
\text { a }\end{array}$ & Máximo & Mínimo & $\begin{array}{c}\text { Median } \\
\text { a }\end{array}$ & Máximo & \\
\hline \multicolumn{2}{|r|}{ Distribuição } & 2,85 & 4,97 & 6,07 & 0,89 & 1,30 & 1,99 & \multirow{3}{*}{$\begin{array}{c}13 \\
\begin{array}{c}\text { Número } \\
\text { de } \\
\text { casos }\end{array}\end{array}$} \\
\hline & - & \multicolumn{3}{|c|}{$\mathrm{m} /$ ponto } & \multicolumn{3}{|c|}{ Conexões/m } & \\
\hline & Ambientes & Mínimo & Mediana & Máximo & Mínimo & Mediana & Máximo & \\
\hline \multirow{6}{*}{ 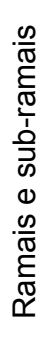 } & Banh. Social e Suítes & 0,95 & 1,56 & 2,79 & 1,82 & 2,86 & 4,22 & 33 \\
\hline & Banheiro Empreg. & 1,45 & 1,85 & 2,63 & 1,90 & 2,50 & 2,98 & 11 \\
\hline & Lavabo & 1,40 & 1,99 & 3,78 & 1,46 & 2,21 & 3,25 & 9 \\
\hline & Área de Serviço & 0,80 & 1,39 & 2,26 & 1,07 & 2,88 & 4,38 & 13 \\
\hline & Cozinha & 0,60 & 1,49 & 2,30 & 1,67 & 2,37 & 5,20 & 13 \\
\hline & Terraços & 0,18 & 0,58 & 5,00 & 2,00 & 3,91 & 5,00 & 6 \\
\hline
\end{tabular}




\subsubsection{Sistema predial de suprimento de água quente}

Tabela 6.52 - Estatísticas gerais (m/ponto; m/ambiente; conexões/m): sistema predial de suprimento de água quente

\begin{tabular}{|c|c|c|c|c|c|c|c|c|}
\hline & \multicolumn{3}{|c|}{ m/ambiente } & \multicolumn{3}{|c|}{ Conexões/m } & \multirow{2}{*}{$\begin{array}{l}\text { Número } \\
\text { de casos }\end{array}$} \\
\hline \multicolumn{2}{|c|}{ Partes } & \multicolumn{3}{|c|}{ Mínimo $\quad$ Mediana } & Mínimo & Mediana & Máximo & \\
\hline & Distribuição & 4,19 & 6,23 & 7,75 & 0,56 & 0,75 & 1,55 & 12 \\
\hline & Retorno & 1,40 & 4,86 & 5,04 & 0,99 & 1,00 & 2,57 & 3 \\
\hline & - & & $\mathrm{m} /$ ponto & & & onexões/ & & Número \\
\hline & Ambientes & Mínimo & Mediana & Máximo & Mínimo & Mediana & Máximo & \\
\hline \multirow{4}{*}{ 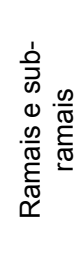 } & $\begin{array}{l}\text { Banh. Social e } \\
\text { Suítes }\end{array}$ & 1,71 & 2,88 & 4,36 & 1,84 & 2,75 & 3,56 & 31 \\
\hline & Banheiro Empreg. & 2,70 & 2,70 & 2,70 & 3,33 & 3,33 & 3,33 & 1 \\
\hline & Lavabo & 3,55 & 3,55 & 3,55 & 1,97 & 1,97 & 1,97 & 1 \\
\hline & Cozinha & 0,60 & 3,00 & 5,98 & 1,19 & 1,90 & 2,86 & 11 \\
\hline
\end{tabular}

\subsubsection{Sistema predial de suprimento de gás}

Tabela 6.53 - Estatísticas gerais (m/ponto; m/ambiente; conexões/m): sistema predial de suprimento de gás

\begin{tabular}{|c|c|c|c|c|c|c|c|c|}
\hline \multicolumn{2}{|c|}{ Partes } & \multicolumn{3}{|c|}{ m/ambiente } & \multicolumn{3}{|c|}{ Conexões/m } & \multirow{2}{*}{$\begin{array}{l}\text { Número } \\
\text { de casos }\end{array}$} \\
\hline & & Mínimo & Mediana & Máximo & Mínimo & Mediana & Máximo & \\
\hline \multicolumn{2}{|c|}{ Distribuição } & 0,30 & 0,85 & 6,20 & 0,71 & 3,60 & 11,67 & \multirow{3}{*}{$\frac{13}{\text { Número }} \begin{array}{c}\text { de casos } \\
\end{array}$} \\
\hline & . & \multicolumn{3}{|c|}{$\mathrm{m} /$ ponto } & \multicolumn{3}{|c|}{ Conexões/m } & \\
\hline \multicolumn{2}{|c|}{ Ambientes } & Mínimo & Mediana & Máximo & Mínimo & Mediana & Máximo & \\
\hline \multirow{2}{*}{ 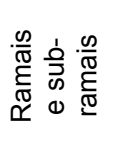 } & $\begin{array}{l}\text { Área de } \\
\text { serviço }\end{array}$ & 0,50 & 3,18 & 8,60 & 0,35 & 1,53 & 12,00 & 12 \\
\hline & Cozinha & 0,78 & 2,25 & 5,76 & 0,88 & 1,58 & 3,85 & 13 \\
\hline
\end{tabular}




\subsubsection{Sistema predial de coleta de esgoto sanitário}

Tabela 6.54 - Estatísticas gerais (m/ponto; conexões $/ \mathrm{m})$ : sistema predial de esgoto sanitário - ramais de esgoto e de ventilação

\begin{tabular}{|c|c|c|c|c|c|c|c|}
\hline \multirow[t]{2}{*}{ Ambientes } & \multicolumn{3}{|c|}{$\mathrm{m} /$ ponto } & \multicolumn{3}{|c|}{ Conexões/m } & \multirow{2}{*}{$\begin{array}{c}\text { Número } \\
\text { de } \\
\text { casos }\end{array}$} \\
\hline & Mínimo & Mediana & Máximo & Mínimo & Mediana & Máximo & \\
\hline Banh. Social e Suítes & 0,61 & 1,08 & 1,73 & 1,26 & 3,02 & 5,63 & 33 \\
\hline Banheiro Empregada & 0,18 & 1,13 & 1,75 & 1,90 & 3,82 & 16,67 & 11 \\
\hline Lavabo & 0,45 & 0,97 & 1,83 & 1,82 & 3,67 & 6,11 & 9 \\
\hline Área de Serviço & 0,17 & 0,90 & 2,87 & 1,35 & 3,13 & 10,00 & 13 \\
\hline Cozinha & 0,39 & 1,08 & 3,03 & 1,58 & 2,95 & 8,97 & 13 \\
\hline Terraços & 1,02 & 1,46 & 1,52 & 1,96 & 1,97 & 2,05 & 3 \\
\hline
\end{tabular}

\subsubsection{Sistema predial de coleta de águas pluviais}

Tabela 6.55 - Estatísticas gerais ( $\mathrm{m} /$ ponto; conexões $/ \mathrm{m}$ ): sistema predial de escoamento de águas pluviais - ramais

\begin{tabular}{|c|c|c|c|c|c|c|c|}
\hline \multirow[t]{2}{*}{ Ambientes } & \multicolumn{3}{|c|}{$\mathrm{m} /$ ponto } & \multicolumn{3}{|c|}{ Conexões/m } & \multirow{2}{*}{$\begin{array}{c}\text { Número } \\
\text { de } \\
\text { casos }\end{array}$} \\
\hline & Mínimo & Mediana & Máximo & Mínimo & Mediana & Máximo & \\
\hline Terraços & 0,08 & 0,26 & 2,92 & 0,51 & 3,85 & 40,00 & 24 \\
\hline
\end{tabular}

